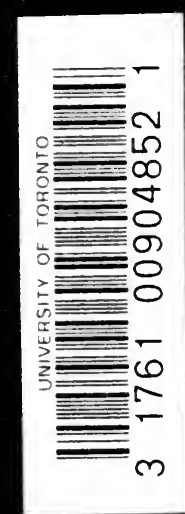


Digitized by the Internet Archive in 2007 with funding from Microsoft Corporation 
OTHER BOOKS ON CANADA

\title{
FRUIT RANCHING IN BRITISH COLUMBIA
}

\author{
By J. T. Bealby, B.A.
}

SECOND EDITION, CONTAINING 32 PAGE ILLUSTRATIONS LARGE CROWN 8vo., CLOTH

Price 38. 6d. Net. (By post 3s. rod.)

\section{SOME PRESB OPINIONS}

"Mr. Bealby's narrative should be of the most solid usefulness to a considerable number of those who think of trying their fortunes in the Dominion."-Pall Mall Gazette.

"A capable practical statement by a man who has carried out the work about which he writes."-Aberdeen Journal.

\section{CANADA : THE LAND OF HOPE}

By E. Way Elkington

CONTAINING 32 FULL-PAGE ILLUSTRATIONS FROM PHOTOGRAPHS. LARGE CROWN 8VO., CLOTH

Price 3s, 6d. Net. (By post 3 s. rod.)

\section{PRESS OPINION}

"The work should prove a safe and reliable guide for anyone intending to emigrate in search of a Canadian home, or for anyone seeking a safe place for the investment of his spare capital, or wanting to know what he should see in an extended Canadian tour."-Aberdeen Free Press. 


\title{
WHEAT - GROWING IN CANADA
}

\section{THE UNITED STATES AND THE ARGENTINE}

INCLUDING COMPARISONS WITH OTHER AR

\author{
BY \\ W. P. RUTTER \\ (M. Com. Manchester University)
}

CONTAINING FIFTEEN DIAGRAMMATIC MAPS AND

THIRTY-THREE CHARTS IN THE TEXT

\section{LONDON \\ ADAM AND CHARLES BLACK I9I I}




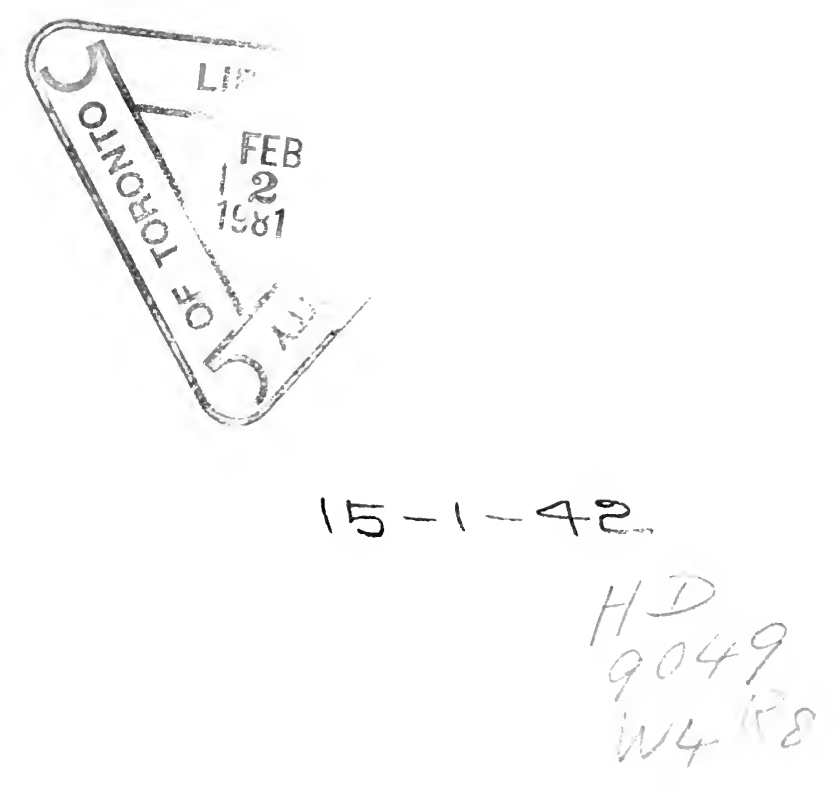




\section{PREFACE}

THIs work was submitted in July, 1910, for the Degree of Master of Commerce of the Manchester University, and was recommended by the examiners for publication. The author is greatly indebted to Professor Chapman, Dean of the Faculty of Commerce, Manchester University, for encouragement ; to Mr. J. McFarlane, M.A., M. Com., Lecturer in Geography in the Manchester University, for advice and suggestion; to Professor Herbertson of Oxford University, and Professor Lyde of London University for their kindly criticism ; to Mr. M. A. Carleton; Mr. A. D. Hall, M.A. ; Dr. T. L. Lyon; Señor E. Lahitte ; Mr. V. H. Olmsted ; Dr. William Saunders, C.M.G. ; and Mr. G. Stone for important data supplied by them ; and to the Agricultural Departments of Canada, the United States, Argentina, and Chile for various statistics promptly supplied.

WILLIAM P. RUTTER.

Manchester, July, 1911. 
-

, 


\section{CON'TEN'TS}

CHAPTER I
GEOGRAPHICAL DISTRIBUTION OF WHEAT IN ANERICA -
PAgE

CHAPTER II

INFLUENCE OF SOIL AND CLIMATE ON THE YIELD AND QUALITY

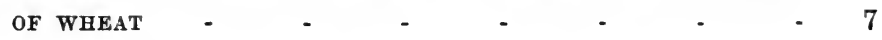

CHAPTER III

OTHER FACTORS AFFECTING THE YIELD AND QUALITY OF WHEAT - 25

CHAPTER IV

CLASSIFICATION OF AMERICAN WHEATS, AND THE DIVISION OF THE AMERICAN WHEAT-FIELDS, ON A CLIMATIC AND SOIL BASIS - 40

CHAPTER V

CULTIVATION AND HARVESTING OF WHEAT -

$-103$

CHAPTER VI

YIELD AND COST OF PRODUCTION -

- 121

CHAPTER VII

TRANSPORTATION OF WHEAT

vii 


\section{CHAPTER VIII}

STORAGE OF WHEAT

III

PAGE

STORAGE OF WHEAT

CHAPTER IX

MARKETING OF WHEAT

- $\quad$ -

- 191

CHAPTER X

PRICE OF WHEAT

CHAPTER XI

ACREAGE, PRODUCTION, AND EXPORTATION -

$-241$

CHAPTER XII

POSSIBILITIES AND PROBABILITIES OF WHEAT IN AMERICA

- 271

BIBLIOGRAPHY

- 303

INDEX 


\section{LIST OF MAPS AND DIAGRAMS}

FIG.

1. RAINFAIL AND TEMPERATURE CURVES, CANADA - $\quad 49$

2. RATNFALL AND TEMPERATURE CURVES, CANADA - - כU

3. ISOTHERMS FOR SUMMER, CANADA: CROP-GROWING SEASON 55

4. CANADA : ISOTHERMS FOR THE YEAR - - $\quad$ - 56

5. PRECIPITATION AND SNOWFALL OF WESTERN CANADA (YEARLY) 57

6. EASTERN CANADA : ANNUAL PRECIPITATION (IN INCHES) AND

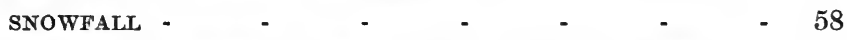

7. RAINFALL AND TEMPERATURE CURVES, UNITED STATES - 75

8. THE UNITED STATES: ANNUAL RAINFALL AND TEMPERATURE

Between pp. 78 and 79

9. ISOTHERMS FOR CROP SEASON, 1897 (APRIL TO SEPTEMBER,

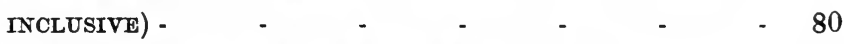

10. RAINFALL AND TEMPERATURE CURVES, UNITED STATES - 81

11. RAINFALL AND TEMPERATURE CURVES, ARGENTINA - - 93

12. ARGENTINA : YEARLY ISOTHERMS (CENTIGRADE) - 94

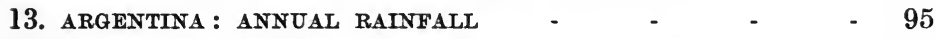

14. RAINFALL AND TEMPERATURE CURVES, CHILE - 101

15. WHEAT YIELDS, BUSHELS PER ACRE - $\quad$ - 126

16. THE RAILWAYs OF CANADA - - Between pp. 136 and 137

17. THE GEORGIAN BAY SHIP CANAL - $\quad$ - $\quad$ - $\quad-147$

18. OANALS OF THE UNITED STATES - $\quad$ - $\quad$ - $\quad$ - 151

19. PRIMARY MARKETS, PORTS, AND NETWORK OF RAILWAYS FROM EACH

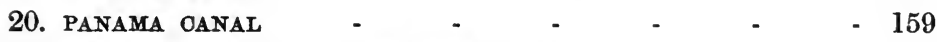

21. RAILWAYS AND PORTS OF ARGENTINA $\quad-\quad-\quad-\quad$ - 165 
FIG.

22. UNITED STATES: PRECEDING ANNUAL PRICE OF WHEAT, AND

ITS RELATION TO WHEAT ACREAGE

23. ARGENTINA: PRECEDING ANNUAL PRICE OF WHEAT, AND

ITS RELATION TO WHEAT ACREAGE

24. WHEAT EXPORTATION OF AMERICA, AND ITS RELATION TO

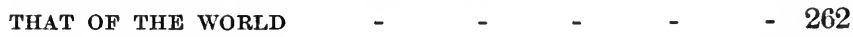

25. WHEAT ACREAGE AND PRODUCTION OF AMERICA, AND THEIR

RELATION TO THOSE OF THE WORLD $\quad-\quad$ - $\quad-263$

26. WHEAT ACREAGES OF CANADA, THE UNITED STATES, AND

ARGENTINA, AND THEIR RELATION TO THE WORLD ACREAGE

27. WHEAT PRODUCTION AND WHEAT EXPORTS OF THE UNITED

STATES, AND THEIR RELATION TO THE WORLD PRODUC-

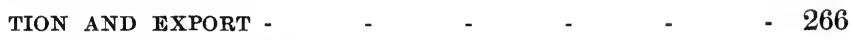

28. WHEAT ACREAGE, UNITED STATES - $\quad$ - $\quad$ - $\quad-267$

29. WHEAT PRODUCTION AND WHEAT EXPORTS OF CANADA, AND

THEIR RELATION TO THE WORLD PRODUCTION OF WHEAT - 268

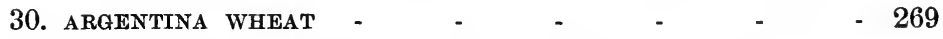

31. WHEAT PRODUCTION AND WHEAT EXPORTS OF ARGENTINA,

AND THEIR RELATION TO THE WORLD PRODUCTION AND

EXPORT

32. RELATION OF POPULATION IN THE UNITED STATES TO WHEAT

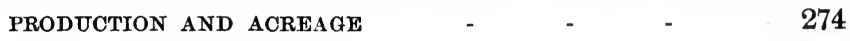

33. PROVINCE OF TOBOLSK 


\section{WHEAT-GROWING IN GANADA THE UNITED STATES, AND THE ARGENTINE}

\section{CHAPTER I}

GEOGRAPHICAL DISTRIBUTION OF WHEAT IN AMERICA

THE subject of wheat-growing has engaged much attention of late years from scientific workers both in Europe and America, and not only has our knowledge been increased, but the prime importance of wheat in the world's markets has been brought prominently to the front.

An investigation into the conditions of wheat-growing in any continent must take into account many factorsphysical, economic, and political.

Among the physical factors which control the growth of wheat, those of climate and soil are most potent; yet our knowledge of their effects on this cereal is as yet far from being perfect; but research in recent years, and the impetus given to scientific agriculture at the present time, would seem to hold out bright prospects for the future. Even with our present knowledge it is possible to fix roughly the latitudinal range of wheat, to determine the regions where the different types of wheat may be grown, and to form an approximately accurate conception of 
what the yield will be under various conditions of soil and climate.

To estimate the effects of economic factors on wheatgrowing is a task of great difficulty, and it is, perhaps, impossible to gauge wholly their control. Nerertheless, we can draw comparatively safe conclusions as to the effects of such economic controls as the price and yield of wheat, the rent of wheat land, the quantity and quality of the labour employed in the wheat regions, and the transportation, storage, and marketing of wheat.

The political controls, which must be investigated, are such factors as tariffs, the various forms of tenure of wheat land, the standards of comfort among the wheat growers, and the character of the Governments of the various countries. The effects of these political controls, like the physical and economic controls, can only be approximately estimated.

America provides an excellent opportunity for the study of the controls of wheat-growing, and the importance of this continent in the world's wheat trade should make merchants and agriculturists keen to study present conditions, and to be able to forecast to some extent the future of wheat-growing in the New World. An endeavour has been made in the following chapters to give the effects of the various controls, and to estimate the probabilities and possibilities of wheat-growing in America.

Wheat was first cultivated in the New World about the third decade of the sixteenth century, but the importance of America in the world's wheat markets practically dates from 1860, when transportation facilities had developed in the Eastern United States. Canada and Argentina 
have come rapidly to the front during the last twenty years, and bid fair to permanently surpass the United States in the future exportation of wheat.

The migration of wheat depends on man, and in America has largely depended on Europeans ; naturally, therefore, its spreading has been mainly in a westerly direction, following the development of transportation systems. This is well seen in the United States, where the geographical centre of wheat production has kept moving steadily to the west (possibly the future may see an eastern movement).

The following table illustrates this movement:

Position of the Centre of Wheat Production in the United States, 1850 -1900.

\begin{tabular}{|c|c|c|c|}
\hline $\begin{array}{l}\text { Census } \\
\text { Year. }\end{array}$ & North Latitude. & West Longitude. & $\begin{array}{l}\text { Approximate Location by Im. } \\
\text { portant Towns. }\end{array}$ \\
\hline 1850 & $40^{\circ} 14^{\prime} 18^{\prime \prime}$ & $81^{\circ} 58^{\prime} 49^{\prime \prime}$ & 57 miles east-north-east of \\
\hline 1860 & $39^{\circ} 59^{\prime} 59^{\prime \prime}$ & $86^{\circ} \quad 1^{\prime} 38^{\prime \prime}$ & $\begin{array}{l}18 \text { miles north by east of } \\
\text { Indianapolis, Indiana. }\end{array}$ \\
\hline 1870 & $40^{\circ} 39^{\prime} 17^{\prime \prime}$ & $88^{\circ} 48^{\prime} 40^{\prime \prime}$ & $\begin{array}{l}82 \text { miles north-east of } \\
\text { Springfield, Illinois. }\end{array}$ \\
\hline 1880 & $40^{\circ} 36^{\prime} 14^{\prime \prime}$ & $90^{\circ} 30^{\prime} 46^{\prime \prime}$ & $\begin{array}{l}69 \text { miles north - west of } \\
\text { Springfield, Illinois. }\end{array}$ \\
\hline 1890 & $39^{\circ} 33^{\prime} 53^{\prime \prime}$ & $93^{\circ} \quad 9^{\prime} 18^{\prime \prime}$ & $\begin{array}{l}138 \text { miles south by east of } \\
\text { Des Moines, Iowa. }\end{array}$ \\
\hline 1900 & $41^{\circ} 39^{\prime} 19^{\prime \prime}$ & $94^{\circ} 5 \theta^{\prime} 23^{\prime \prime}$ & $\begin{array}{l}70 \text { miles west of Des } \\
\text { Moines, Iowa. }\end{array}$ \\
\hline
\end{tabular}

A glance at the table shows that the centre has moved in this period of fifty years $13^{\circ} 0^{\prime} 34^{\prime \prime}$, or about 680 miles to the west. The northward movement was about ninetynine miles. The latitude variation was marked by slight 
fluctuations for forty years, and then in a single decade wheat moved more than two degrees northwards, owing to rapid expansion in the North-West. The greatest westward movement was in the first decade (1850-1860), amounting to more than 200 miles. The westward movement in the ten years, 1890-1900, was a little less than 100 miles. Probably wheat will now move in a southerly, as well as an easterly, direction in the United States as population increases, and land grows in value.

A similar tendency for wheat to migrate to the west is "ery noticeable in Canada, and in Argentina to a smaller extent. In Canada at the present time there is also a northerly movement of wheat, largely due to the introduction of hardy varieties of wheat; in Argentina, also, a movement towards the south is evident, this southerly direction corresponding to Canada's northerly direction, when considered latitudinally. The wheat areas are being extended into colder regions, where but a few years ago it was considered impossible for wheat to grow.

It has been denied that wheat can be raised in Canada north of $\mathbf{5 5}$ degrees north latitude, but this notion has had to be abandoned, for wheat is gradually creeping nearer and nearer to the Arctic Circle. At Sitka, Alaska, 56 degrees north latitude, spring wheat matured in 1900 and 1901. In the Peace River Valley wheat has been successfully grown for some years past, and at Fort Vermilion, north latitude 58.4 degrees, there is a roller mill, whose capacity is thirty-five barrels per day, and the wheat ground in this mill is all grown in the vicinity. Wheat has been harvested at Fort Simpson in north latitude $61 \cdot 8$ degrees, and at Dawson City, 64 degrees north 
latitude, wheat has matured in favourable seasons. In the more northerly tracts, however, present factors show that the chances of failure are too many for wheat cultivation to be a commercial success.

The latitude range of wheat in North America may be said to lie between the parallels of latitude 30 degrees north and 60 degrees north. For successful wheat-growing on a commercial basis the limits are 35 degrees north latitude and 55 degrees north latitude, with more chances of expansion in a northerly direction than a southerly by the introduction of cold-resisting wheats.

If Mexico and the Republics of Central America are included with North America, the latitude range of wheat would be from Nicaragua to the Mackenzie River, which reaches over 50 degrees of latitude. These countries, with the exception of Mexico, however, produce a very small amount of wheat.

In South America wheat is grown both south and north of the Equator, but the commercial wheat regions all lie to the south of the Equator. The latitude range south of the Equator lies between the parallels of latitude 0 degree and 45 degrees south, but the commercial wheat regions lie between the parallels 30 degrees south and 42 degrees south, with possibilities of development to the south. North of the Equator wheat ranges to the north of South America in Venezuela and Columbia, almost to the parallel of 10 degrees north, but all the wheat regions north of the Equator produce exceedingly small amounts of wheat.

Another factor having its influence on the range of wheat is altitude, which may be considered as the com- 
plement of latitude. In Colombia and Ecuador, at a height of 10,000 feet, wheat is cultivated on the Equator. In South-Western Arizona and the Imperial Valley of Southern California wheat is grown on land 50 to 260 feet below sea-level. Generally it may be stated that wheat is grown in America at altitudes varying from 100 feet below sea-level to over 10,000 feet above sea-level, but that by far the greatest percentage of wheat is grown at altitudes ranging from 500 to 1,500 feet above sea-level. 


\section{CHAPTER II}

\section{INFLUENCE OF SOIL AND CLIMATE ON THE YIELD}

AND QUALITY OF WHEAT

There are few plants in cultivation so indifferent to soil conditions as wheat. It can be grown on any soil provided it be fertile, and is as much at home in the sands of North Africa as in the "black lands" of Russia. The different soils of the United States, on which wheat is grown, illustrate in a remarkable manner the adaptability of the various kinds of wheat to the land on which they are grown. In Northern Texas, at an elevation of 2,000 to 3,000 feet above sea-level, certain of the fine sandy loams, derived from the weathering of the red sandstone and sandy shale rocks, constitute excellent wheat lands. Farther north, through Kansas and Nebraska, heavier loams and stiff clays, derived from the weathering of limestone and calcareous shales, also produce excellent winter wheat. Still farther north in the two Dakotas, winter wheat gives place to spring wheat of a considerable number of varieties, and the dark rolling prairie soils, derived from glacial till and loess, and even the heavy black soils, formed as glacial lake sediments, are all used to good advantage for the production of wheat. In the central prairie States, south of the Great Lakes, the soils consist of yellow or light- 
brown glacial materials, and have in the past been cultivated with wheat, giving yields as high as those now known in the existing wheat-belt west of the River Mississippi.

Throughout the Cumberland and Shenandoah Valley, in the States of Pennsylvania, Maryland, and Virginia, the soils derived from the weathering of the CambroSilurian limestones, which form the floor of the valley, have constituted excellent wheat lands since their earliest occupation two hundred years ago. A considerable amount of wheat is produced upon the heavier clay and clay-loam soils formed by the weathering of the granitic and crystalline schist rocks of the Piedmont sections of Virginia and North Carolina. The older wheat-belt along the south shore of Lake Ontario, in the State of New York, still produces heavy yields of wheat upon heavy chocolate clays and clay loams deposited from the glacial lakes, which antedated the present lake system. In the northwestern portion of the United States the soils derived from the weathering of extensive sheets of basaltic lava in Idaho and Eastern Washington produce some phenomenal yields of wheat, and the ancient marine and lacustrine sediments in the Great Central Valley of California have for some years been "dry-farmed" to wheat.

Though wheat can be grown on practically any fertile soil, yet the leading wheat lands are of the finer textures, such as heavy sand loams, silt loams, clay loams, and clays. These soils, while lifting water easily by capillarity, are freely traversed by air and percolating water, and are retentive of moisture.

The retentive capacity of any soil for moisture is regulated almost entirely by its physical characteristics, 
though modified to some extent by physiographic position. The wheat plant, from its nature as a grass, requires a considerable amount of moisture, and therefore one of the chief essentials of a wheat soil is that it should be capable of retaining moisture, and this is of especial importance in arid and semi-arid lands. The greater part of the water, which falls as rain, passes into the soil, and is held by the soil particles against the force of gravity, and is known as capillary water. Capillary water cannot be seen as liquid water, but its presence may be recognized by its effect upon the colour of the soil. If the water is in too great a quantity to be dispersed by capillarity, the rain-water runs down into the lower soil, and finally joins the ground-water, raising its level temporarily. When the weather is dry, the capillary water evaporates from the surface of the soil, and the soil then draws more water from below, but not in sufficient quantity to replace wholly that lost by evaporation, and, therefore, the capillary water decreases until another rainfall occurs.

It is from capillary water that the wheat plant, for the most part, obtains the water containing dissolved food constituents necessary for its growth. In order that wheat may make its best development, the soil must be in such a physical condition that the roots of the plant can readily penetrate it, and ramify through it. The soil, too, must contain sufficient capillary water to supply the needs of the plant, and this water must be renewed as it is taken up. It is quite possible for a soil to be physiologically dry, and yet contain more moisture than another soil, which supplies water to plants. Large airspaces in the soil should be absent, as these cause the 
soil to dry out readily, and prevent the fulligrowth of the many fine branching rootlets necessary for the best development of the wheat plant. The soil should be porous, but not loose; firm, but neither hard nor consolidated; and close-grained, but not adhesive. Light clays and sandy loams fulfil these conditions, and thus make ideal soils for wheat production. Wheat soils should be rich in humus, or decaying vegetable-matter, if the best-developed kernels are to be obtained. Though not in itself a direct form of plant nourishment, humus is, nevertheless, one of the most important constituents of all fertile soils, as it is the natural storehouse and conservator of nitrogen, and it increases the power of the soil to absorb and retain moisture. Where humus is abundant in the soil, it is associated with a liberal supply of nitrogen, and it has been noticed that the amount of humus present gives an excellent indication of the quantity of organic nitrogen which the soil contains. Humus furnishes the food upon which the micro-organisms in the soil live, and these convert the organic nitrogen of the soil into nitrates, the compounds, which alone can supply the wheat plant with the nitrogen, which is so essential to its growth. Typical humus soils are the "black soils" of the North American prairies, which contain very large proportions of organic matter to considerable depths in the subsoil. A soil from Winnipeg contained $0.424,0.327,0.158$, and 0.107 per cent. of nitrogen in the top 4 feet of soil successively.

The subsoil is of importance in the growth of wheat, for if it is not congenial the root system of the wheat has to be developed in a shallow foraging ground, and the full 
development of the plant is hindered. It is a fortunate circumstance that deep congenial subsoils are generally characteristic of arid and semi-arid regions, so that the root systems of crops may have deep, as well as broad, pasturage.

It is difficult to trace the effect of the soil upon the composition and yield of wheat, as climate often masks the effect of the soil. We depend for most of our information on experiments with fertilizers. Lawes and Gilbert, experimenting during the period 1845 to 1854 , concluded that there is no evidence that the nitrogen content of the wheat-kernel can be increased at pleasure by the use of nitrogenous manures. Van Gohren, experimenting in 1864, showed plainly that the wheat-kernels on manured land developed better than on unmanured land, and that with this better development there was an increase in the percentage of starch, and a decrease in the nitrogen, but a larger yield per acre. In 1884 Lawes and Gilbert reported that, after experiments extending over sixteen years, they concluded that the largest crops and bestdeveloped kernels were obtained from soils treated with barn-yard manure, but that these kernels contained the lowest percentage of nitrogen; that the crops on unmanured land stood next in these respects, except in yield; and that those on the soils receiving ammonium salts produced the most poorly-developed kernels, but of highest nitrogen content, and larger yields resulted than from those on the unmanured soils.

It would seem that if wheats of the same variety are grown under the same climatic conditions, they will have approximately the same percentage of nitrogen if allowed 
to mature fully, but any permanent interruption in the process of maturation will result in a higher percentage of nitrogen, and in this latter case the percentage of nitrogen will depend upon the stage at which development was interrupted, and also upon the amount of nitrogen accumulated by the plant, that being greater on soils manured with nitrogenous fertilizers alone than on exhausted soils, and greater on soils receiving complete manures than on exhausted soils receiving only nitrogenous fertilizers, provided the stage at which development ceased be the same in both cases.

The influence of soil moisture upon the composition and yiela of wheat has recently received a considerable amount of attention. Experiments were conducted by Prianishinkor previous to 1900 , in which wheat was raised with different degrees of moisture, but in the same soil and under the same conditions of light and temperature. With a larger amount of moisture in the soil there was a lower nitrogen content in the grain. Mr. A. D. Hall, M.A., in an experiment of a similar nature, found that wheat ripened later when the water-supply was greater than the optimum, and in a lesser time when the watersupply was less than the optimum, the premature ripening in the latter case resulting in an unmatured grain.

Traphagen, in 1902, reported marked changes in the composition of wheat grown with and without irrigation at the Montana Experimental Station. The unirrigated wheat in all cases possessed the light, shrunken kernel characteristic of wheat raised without sufficient moisture. Widtsoe, Utah Experimental Station, in Bulletin 80, reported that experiments with the same variety of wheat 
showed that with an increase in the water used for irrigation up to 30 inches, there were a general increase in the yield of grain, and a decrease in the nitrogen content. The following was the record kept :

\begin{tabular}{|c|c|c|c|}
\hline Plot. & $\begin{array}{c}\text { Water applied in } \\
\text { Inches. }\end{array}$ & $\begin{array}{c}\text { Yield per Acre in } \\
\text { Bushels. }\end{array}$ & $\begin{array}{c}\text { Yield in Pounds per } \\
\text { Acre of Nitrogen. }\end{array}$ \\
\cline { 1 - 1 } 317 & $4 \cdot 63$ & $4 \cdot 50$ & $10 \cdot 7$ \\
319 & $5 \cdot 14$ & $3 \cdot 83$ & $8 \cdot 5$ \\
320 & $8 \cdot 73$ & $10 \cdot 33$ & $19 \cdot 7$ \\
318 & $8 \cdot 89$ & $11 \cdot 33$ & $21 \cdot 1$ \\
321 & $10 \cdot 30$ & $14 \cdot 66$ & $25 \cdot 9$ \\
325 & $12 \cdot 09$ & $11 \cdot 16$ & $22 \cdot 8$ \\
322 & $12 \cdot 18$ & $11 \cdot 66$ & $25 \cdot 8$ \\
326 & $12 \cdot 80$ & $13 \cdot 00$ & $21 \cdot 3$ \\
327 & $17 \cdot 50$ & $15 \cdot 33$ & $25 \cdot 3$ \\
328 & $21 \cdot 11$ & $17 \cdot 33$ & $26 \cdot 4$ \\
329 & $30 \cdot 00$ & $26 \cdot 66$ & $35 \cdot 8$ \\
330 & $40 \cdot 00$ & $14 \cdot 50$ & $23 \cdot 8$ \\
\hline
\end{tabular}

Dr. T. Lyon, Collaborator of the Bureau of Plant Industry, Washington, says : "High nitrogen content arising from a small supply of soil moisture is sometimes due to a restricted development of the kernel." In experiments conducted by him he found that on soils with less moisture than the optimum, there was a greater absorption of nitrogen by the wheat than on those having more moisture than the optimum.

Soil temperature is very important in connection with the growth of wheat, and is especially so in the case of the germination of the seed, for which not only is a certain minimum temperature requisite, but for several degrees above this minimum the germination is so slow and irregular that the young plant is very liable to perish while remaining in such a critical condition. The tem- 
perature for the germination of wheat is $32^{\circ}$ to $41^{\circ} \mathrm{F}$. minimum ; $77^{\circ}$ to $88^{\circ} \mathrm{F}$. optimum ; $88^{\circ}$ to $110^{\circ} \mathrm{F}$. maximum.

The formation of nitrates in the soil is largely dependent on soil temperature, for the nitrification bacteria cease their work below $41^{\circ} \mathrm{F}$., and above $130^{\circ} \mathrm{F}$., their optimum temperature being about $99^{\circ} \mathrm{F}$. The inadequacy of the production of nitrates for the needs of the crop due to a low temperature is often seen in winter wheat in springtime, and may be connected with the yellow colour of the young corn during a spell of cold and drying east wind.

Black soils are good absorbers of the sun's rays, and as their humus contents are great the soils of the American prairies are rich in nitrates, for the nitrification bacteria find there their best environment.

Though much research and many experiments have in recent years increased our knowledge of the controlling effects of soil and climate on wheat, yet we are still unable to fix any definite limits to the growth of this cereal, either with respect to soil or climate.

The two factors, soil and climate, are closely interwoven in their influence on the wheat plant and the wheat grain ; but of the two, climate is the more potent in its effect, and this is especially true in regard to the quality of the grain, and the yield of the wheat.

Wheat is normally a winter annual, but in countries possessing what Schimper calls a "steppe" climate, spring wheats are largely grown. The "steppe " climate may be defined as one whose winter is very severe, too cold in fact for the wheat plant to survive. During the spring, showery weather prevails, with a rapidly-rísing 
temperature, and as the season advances both the heat and the dryness become extreme. The period of growth of spring wheats is of necessity short ; they are frequently sown as late as April, or even in May, and the harvesting may tale place in July; thus, the whole period of growth does not $€$ xceed five months, and is, frequently, much less.

These spıing wheats, grown under the influence of a " steppe " climate, are classified by the miller as "strong " wheats. The grain of such wheats is characterized by its high gluten content, and by its ability to give a better loaf than "weak" wheats do. They are largely used by millers to increase the "strength" of other wheats. What really constitutes the "strength" of "strong" wheats has not yet been ascertained, but it is known that high gluten content is a characteristic. Climate is doubtless one of the most potent factors in producing "strength." This is clearly demonstrated by the fact that many "strong " wheats fail to produce their "strength" when grown in England. The belief was held at one time that sunshine during the later stages of growth resulted in "strength" ; but there are many foreign wheats, notably the Californian, which have their last three months of growth in cloudless weather, and yet remain "weak." It is undoubtedly true that sunshine has some effect on "strength," but its exact nature has yet to be determined. Kowalewski, the distinguished Russian investigator, experimented with spring wheats, growing them in different parts of Russia, from the far north at Arkangelsk to the southern province of Kherson. He found that in higher latitudes the grain ripened in a shorter time than in the more southern districts, the 
difference varying at different points from twelve to thirty-five days. He attributes the early ripening and the high quality of the grain in the north largely to the influence of light during the long summer days. Va:iety, also, is a factor in the production of "strength," for "weak" wheats, such as "Squareheads," when grown on the same soils, which give such superb wh sats as the Hungarian "Tizra Videki," still keep as "weak" as when grown in England. Again, experiments conducted in England under the direction of the Home-grown Wheat Committee, assisted by the Incorporated National Association of British and Irish Millers, have demonstrated that a few samples of wheat, notably "Red Fife" obtained from Canada, retain their strength when grown in England.

Winter wheats, or wheats sown in the autumn, which are generally soft, are produced under different climatic conditions as compared with spring-wheat conditions. Professor Brewer, in his report on Cereals in the Tenth Census Report of the United States, admirably states the necessary climatic conditions: "The ideal climate is one with a long and rather wet winter, with little or no frost, prolonged into a cool and rather wet spring, which gradually fades into a warmer summer, the weather gradually growing drier as it grows warmer, with only comparatively light rains after the flowering of the crop, just enough to bring the grain to maturity, with abundant sunshine and rather dry air towards the harvest, but without dry and scorching winds until the grain is fully ripe, and then hot, dry, and rainless weather until the harvest is gathered." 
Soft "weak" spring wheats are grown in America as well as the "strong" steppe spring wheats ; they result largely from the nature of the soil, the comparatively large rainfall, the high humidity of the air, and the comparatively medium temperature during their growth and ripening in the regions where they are grown.

The Macaroni or Durum wheats, now being exploited in the western states of the United States, occupy a special class by themselves, some being " strong," others " weak." All are drought-resisting, and almost all are best adapted for spring sowing. The ideal climatic conditions necessary are a very low a verage annual rainfall, frequently only 10 or 11 inches, and rarely exceeding 18 inches, but this rainfall should occur largely during the early growing season; a clear air; great extremes of temperature; and dry and intense heat during the later stages of growth and ripening. Semi-arid conditions are thus necessary.

The "tillering" of wheat largely depends on climate; wheat throws out side-shoots after the plumule has appeared above the surface, and these branches may occur at any node covered with soil. The number of stalks from one seed varies under different conditions ; usually there are six, but, in exceptional cases, over fifty have been observed. Cold weather in the early stages of the growth of wheat encourages a long period of subsequent growth, and so "tillering" is increased. Early sowing is frequently advisable, for late-sown wheat may not have time to "tiller," and it is evident that the greater the "tillering" the greater the possibilities of increased yield.

A knowledge of the temperature required for the growth of wheat is of the first importance. The life of the plant 
is practically suspended below $41^{\circ} \mathrm{F}$., according to modern scientists (though De Candolle preferred $42^{\circ} \mathrm{F}$.) ; all the various changes which are essential to the development of the plant, such as germination, vegetative activity and the bacterial process in the soil, show a similar dependence upon temperature. These vital actions cease below a certain minimum, above which they increase with the temperature until an optimum is reached, when the action is at its greatest; beyond this point the action decreases, until a superior limit is reached, which again suspends all change. The temperature required by wheat is $41^{\circ} \mathrm{F}$. minimum ; $83.6^{\circ} \mathrm{F}$. optimum; and $108.5^{\circ} \mathrm{F}$. maximum.

It is known that wheat demands a higher temperature than any other cereal of the temperate zone, with the exception of maize. What is the exact part that heat performs in the growth of the plant is not yet fully known. The mean temperature required for the successful cultivation and ripening of wheat has been given as $65^{\circ} \mathrm{F}$. for forty-five to sixty days, and $55^{\circ} \mathrm{F}$. for three or four months of the growing season. Such a general statement, while possessing elements of truth, is of little scientific value. If an exact knowledge of the amount of heat required for the growth and ripening of wheat could be acquired, it would be of great theoretical and practical value. Naturally, therefore, we find that it has received considerable attention from scientists; amongst others Boussingault, Hervé Mangon, and De Candolle on the Continent, and Dr. Gilbert, F.R.S., in England, have endeavoured to determine the thermal constants for the ripening of wheat. The results are expressed in what are termed "daydegrees," following the analogy of the foot-pound, the 
term signifying a degree of temperature continued throughout the whole day. Dr. Gilbert's results were $2,023^{\circ} \mathrm{F}$., $2,189^{\circ} \mathrm{F}$., and $1,904^{\circ} \mathrm{F}$., results derived respectively from the Greenwich monthly means, the Greenwich daily means, and the accumulated mean temperature values for the Eastern and Midland Counties published by the Meteorological Office. Gilbert selected as his zero $42^{\circ} \mathrm{F}$., because this was regarded then as the critical temperature at which the processes involved in the growth of the plant became active, whilst they remained dormant when the thermometer fell below it.

Mr. R. H. Curtis, of the Meteorological Office, London, experimenting in 1905, came to the conclusion that it was not right to select an arbitrary date for commencing the calculations, as had been done by Gilbert and others, but that they ought to cover the whole interval between sowing and reaping. Again, it is not absolutely certain that the base temperature selected is the most suitable, or that it should be maintained through the whole period, for it is quite possible that growth may go on with lower temperatures than $42^{\circ} \mathrm{F}$., or that, at any rate, with such lower temperatures certain changes and modifications take place in the plant, which prepare it for more active development later on. Mr. Curtis, through the kindness of Mr. A. D. Hall, M.A., obtained the dates of sowing and reaping of winter wheats at Rothamsted over a long series of years, and for the purpose of his calculations he employed temperature observations actually made at Rothamsted, instead of using a mean value for a large district. The mean amount of accumulated temperature above $42^{\circ} \mathrm{F}$., required for the growth and ripening of 
autumn-sown wheat, is shown by his calculations to be $1,961^{\circ} \mathrm{F}$.

From data supplied to me by the Director of the Experimental Station, University of Minnesota, and covering a period of three years, I ascertained that the number of day-degrees for spring wheats was approximately $2,000^{\circ} \mathrm{F}$. It was noticeable in the calculations that the wheat plant required a greater number of daydegrees for its development when the rainfall was abov the normal, and the percentage of sunshine less than th normal.

It would seem that with our present knowledge the number of day-degrees required can only be approximately known. Many difficulties at present stand in the way of a scientifically accurate result, and if the future shall see this result attained, then attention must be given to the following phenomena: Rainfall, and its effect in prolonging the period of growth ; the soil, particularly as regards its dryness or humidity, shortening or lengthening the period of growth ; the effect of the humidity of the atmosphere on the growth of the wheat plant; the action of sunshine on the wheat plant ; the correct base temperature, if possible; and that each variety of wheat may require its own day-degrees.

The effect of climate upon the yield and composition of the wheat crop has in recent years received much attention, both in Europe and in America. Lawes and Gilbert (1880 and 1884) found almost invariably that a season, which favoured a long and continuous growth of the plant after heading, resulted in a large yield of grain, a high weight per bushel, and a plump kernel of low nitrogen 
content. Dr. T. L. Lyon states: "Climate is a potent factor in determining the yield and composition of the wheat crop, and its effect is produced by lengthening or shortening the growing season, particularly that portion of it during which the kernel is developing. A moderately cool season, with a liberal supply of moisture, has the effect iof prolonging the period during which the kernel is developing, thus favouring its filling out with starch, the leposition of which is much greater at that time than is that of the nitrogenous material. With this goes an increase in volume weight, and an increased yield of grain per acre. On the other hand, a hot dry summer shortens the period of kernel development, curtails the deposition of starch, leaving the percentage of nitrogen relatively higher, and gives a grain of lighter weight per bushel and smaller yield per acre."

Again, in his investigations, he writes : "The properties of the wheat-kernel, characteristic of a Continental ("steppe") climate, and rich soil, are probably due to rapid nitrification and highly stimulated growth, causing a large accumulation of nitrogen by the crop, and to incomplete maturation, caused either by heat or frost, or lack of moisture, resulting in high nitrogen content."

Mr. F. T. Shutt, M.A., Chemist of the Central Experimental Farm, Ottawa, says: "Climatic conditions influence the quality of the wheat through the vegetative processes by shortening or lengthening the time which elapses between the formation of the kernel and its maturity-the shorter the period the higher the protein content within certain limits. High temperatures, long days, and absence of excessive moisture during the 
ripening process, we have evidence, hasten the maturation of the grain, and increase its percentage of gluten. These are the conditions that prevail in the North-Western wheat areas in those seasons which give the largest proportion of first quality wheat, and we may, therefore, argue that in them we have an asset fully equal in importance towards the production of the finest grain to that which we possess in our fertile prairie soils."

That "strong" wheats are not fully matured is proved by the fact that a variety of wheat well adapted to a "steppe" climate will, when planted in a cool, moist one, immediately grow plumper, and the kernel weight will increase. This was the case in the experiment of taking Minnesota wheats to Maine. It is easy to demonstrate that lack of moisture leads to premature ripening. Mr. A. D. Hall, M.A., took three pots of wheat, and grew them under similar conditions of heat, but the supply of water was maintained throughout in one pot below, in another at, and in the third above, the optimum. The result was that the wheats grown under the lowest water conditions ripened a week or ten days earlier than those grown in the other two pots; and, though not stated, the grains of the earlier ripened wheats doubtless possessed a relatively high nitrogen content. Mr. Hugh A. Miller, Assistant Agriculturist, Washington, in a letter bearing on this point, says that from his own observations in the western parts of the United States, where the rainfall comes during the summer, it frequently happens that in low places that hold the moisture better than the hillsides, wheat will stay green and ripen several days later than on the hillsides. 
It is known that the humidity of the air is of prime importance to the growth of the wheat plant, but the actual changes in the plant which take place by virtue of its low or high percentage remain yet to be fully investigated. That the inferior quality of grain in humid areas is largely due to the prevailing humidity of the air, and lack of sunshine seems, however, to be positive. It is not so much the great precipitation of humid areas that results in small gluten content of the wheat-grain, but the combination of great rainfall, and great humidity of the air with the consequent decrease of sunshine.

A factor of great importance to North-West Canada is that it lies farther north than the other wheat regions of America, and the wheat-grains under the prevailing climatic and soil conditions attain a more perfect nitrogen development, and there is also a greater yield per acre on land of given fertility-possibly largely due to better "tillering"- than on that of regions of equal fertility lying to the south, and possessing a milder "steppe" climate.

It is evident that both a "steppe" climate, and a soil seriously depleted of plant food, or with a shortage of moisture, yield wheat-grains not fully matured, but with kernels of a higher nitrogen content than when fully matured, and that this incomplete maturation is accompanied by a lower yield per acre than when grown under conditions allowing complete maturation. The problem for the wheat grower and breeder of the future is thus to obtain a "strong" wheat, which shall yield better than the present "strong" wheats, give a fully-developed kernel, and yet keep its "strength." 
It may be concluded from foregoing statements that soft wheats are associated with an insular climate; that hard, "strong," spring wheats are associated with a "steppe" climate, and rich black soils; and that Durum wheats are associated with a very low rainfall, and frequently alkali soils.

Several writers have succeeded in connecting periodic variations of the weather directly with wheat yields. Brückner has been perhaps the most successful, for he gives good evidence by taking five yearly averages, that wheat harvests vary synchronously with rainfall in a period of about thirty-five years. During cool, damp periods the crops of oceanic climates tend to be spoiled by too much wet, whilst those of "steppe" climates are then usually excellent, having just sufficient moisture. On the other hand, during warm, dry periods the harvests are on the average more abundant in oceanic territory, and deficient through drought in the hot, dry, continental areas. This is proved by the crop statistics of North America during the latter half of the last century. 


\section{CHAPTER III}

OTHER FACTORS AFFECTING THE YIELD AND QUALITY OF WHEAT

In considering the quality and yield of the various types of wheat grown on the American continent, it is necessary to trace the effects of other factors beside those of soil and climate. Among these factors, seed selection, wheatbreeding, irrigation, dry farming, soil fertilization, crop rotation, and scientific farming methods are potent in their effects.

Seed selection has only attained commercial importance in comparatively recent times, but of necessity selection has from the first been a most powerful influence in the development of wheat, though man failed to recognize its operation. By careful selection the farmer may obtain better-yielding wheats, may improve the quality of the grain, may discover early ripening wheats, and may improve many other features of wheat. Lyon and Hays in the United States, and Saunders in Canada, have shown that seed selection increases the yield of wheat, and improves its quality. Among important American wheats improved by selection may be mentioned the "strong" spring wheats "Red Fife," Minnesota Nos. 163 and 169, the hard winter wheat "Turkey Red" of Kansas, and the soft winter wheat "Fultz" of the Eastern United States. 
Wheat-breeding was, till 1896, in a very chaotic state. The numerous improvements made by the breeder before this time were the results of happy chance. In 1896, however, a series of long-lost researches on inheritance were discovered, which put "breeding" on a scientific basis. These were the work of Gregor Mendel, a former abbot of Brünn, in Austrian Silesia. It was in the garden of the monastery that he performed his famous experiments on plant hybrids. Mendel experimented with the pea. He worked with twenty-two different races of peas, and chose seven characteristic features in which pairs of races differed essentially, and on each feature he conducted separate sets of experiments. In each of the latter he crossed two pure races, which differed essentially with regard to the feature in question. The hybrids produced from the pure races were called the first hybrids. On the results obtained from each race of first hybrids by selffertilization he concentrated his energies. Each group of first hybrids produced a group of second hybrids; these produced third hybrids, and so on.

In the first hybrids, one characteristic entirely obliterated the other. The first hybrids, obtained from tall and dwarf plants, were all tall plants. Mendel called the tall stems the "dominant" characteristic, and the short stems the "recessive" characteristic. In the second hybrids the " recessive" characteristics appeared in one quarter of the plants, the ratio being three to one. He found, by taking a typical group of four second hybrids (one dwarf and three tall plants), that the plants derived from the dwarf plant were all dwarfs, and that one of the tall plants gave only tall third hybrids. The remaining two 
tall plants, however, gave mixed third hybrids in the proportion of three tall plants to one dwarf, thus behaving like the first hybrids. The same results were obtained in the case of all the other six features investigated.

Every plant is produced by the union of two germ cells, a male and a female, in fertilization ; and the plant in its turn produces other germ cells, male and female, in its flowers. Mendel propounded the following ingenious theory to explain the results obtained :

(a) Each germ cell is always pure, either pure "dominant," or pure "recessive."

(b) The conjugation of two "dominant" cells produces pure "dominant" plants, and of two "recessive" cells produces pure "recessive" plants.

(c) The conjugation of a "dominant" cell with a "recessive" cell always produces a "dominant" plant, which will bear "dominant" and "recessive" germ cells in equal numbers.

Each of the first hybrids falls under rule (c), and is, accordingly, a "dominant" plant bearing "dominant," and "recessive" germ cells in equal numbers. Four equally probable cases may result from the self-fertilization of the first hybrids :

1. A "dominant" male cell conjugating with a "dominant" female cell will, by rule (b), produce a second hybrid, which will breed true perpetually.

2. A "recessive" male cell? with a "recessive" female cell will, by rule (b), produce a "recessive" second hybrid, which will breed true perpetually.

3. and 4. A "dominant" male cell, with a " recessive" female, and vice versa, will, by rule (b), produce "domi- 
nant" second hybrids, bearing mixed germ cells-i.e., plants of the same class as the first hybrids, which, when self-fertilized, will accordingly give results similar to the first hybrids.

A knowledge of the Mendelian laws enables the wheat breeder to breed types to order, and these new types can be fixed. Usually four to six years elapse before groups are obtained, which are fixed in regard to the eight or ten characters which are commonly observed in cereals. If "breeding" were conducted on an enormous scale, some fixed types could be obtained at an earlier stage. The new varieties breed as true to type as the oldest varieties in existence. Experiments conducted in Europe and America show that Mendelian selection has been successfully applied to wheat, and that among many "points" which can be handled as separate units, independently of other "points," are "strength" and "weakness," susceptibility to and immunity from disease, and the colour of the skin. It has been demonstrated that, subject to conditions due to the influence of soil and climate, "breed" is the predominant factor in the production of "strength" in wheat.

The first wheat breeder in the United States was C. G. Pringle, who commenced wheat-breeding in 1877. His best-known wheat is Pringle's Defiance. Blount, who followed him, produced the wheats Amethyst, Felspar, Ruby, and Granite. Saunders, in Canada, has produced two excellent early ripening varieties in the Preston and Stanley. His main endeavour is to extend the wheat fields of Canada towards the north. Jones, of Newark, New York, succeeded in increasing the gluten content of 
the wheats of the Eastern United States by the production of the varieties of wheat known as Winter Fife, Early Red Clawson, and Early Genesee Giant.

Of late years some new ideas in regard to the origin of species have been made prominent, especially by De Vries. $\mathrm{He}$ lays stress less on the gradual changes in large masses of plants, and more on the sudden changes in individuals. Each plant has a measure of individuality, usually slight and unimportant, but occasionally so striking as to be easily observed. As these points of individuality are often transmitted to all the descendants of the original plant, it is possible to obtain some strains of unusual value by keeping separate the progeny of each selected individual, which is chosen because of some element of apparent superiority over the others.

Whatever conception of variation the wheat breeder or grower may hold, he proceeds either by the simple process of selection, or by the compound process of selection, hybridization, and selection.

It is impossible to predict all the possibilities of "wheatbreeding," for they are sure to be slow, and, for the time being, they are likely to be masked by contemporaneous changes due to economic causes. Probably the wheat acreage will be appreciably increased by its aid, and the quality and yield per acre will doubtless be improved by its means.

Irrigation is the artificial application of water to insure crop production, and is an operation requiring much knowledge and skill. King says: "To handle water on a given field, so that it shall be applied at the right time in the right amount, without injuring the crop, 
requires an intimate acquaintance with the conditions, good judgment, close observation, skilful manipulation, and patience after the field has been put into excellent shape." A close study of the agricultural conditions, under which artificial watering is being practised throughout the world to-day, reveals the fact that irrigation is not confined to those countries, where the rainfall is so scanty, that nothing will grow without it. On the contrary, in many countries where irrigation has been brought to the highest state of perfection, the natural rainfall is very heavy. Indeed, there must always be contiguous territory of considerable precipitation in order to produce springs and streams, from which water may be diverted for irrigation purposes. Where irrigation water can be economically applied to lands, it has some important advantages in crop production over the natural rainfall, even where that is large. In the first place, irrigation water can be supplied at such times and in such quantities as it is needed, and this gives a certainty to results, which is impossible, where the outcome must depend upon the chance of adequate or inadequate, timely or untimely rainfall. Secondly, water used for irrigation contains almost without exception, larger percentages of both the organic and the ash ingredients of plant food than rain-water does, and as this is largely in the soluble form, it becomes at once available, and thus stimulates growth. Irrigation in the wheat areas will certainly result in larger yields per acre, but where irrigation is practised the tendency is to practice diversified farming, or the rotation of crops. Wheat takes a considerable amount of water, and this 
at a time when water is usually very scarce. The yields of wheat are usually not sufficient to make the value of the product equal to that of other crops that can be grown in the same climate with less water.

Irrigation is practised to some extent in the wheat fields of Mexico, Chile, and Argentina. In Canada the largest irrigation works are situated in the Bow River Valley. Much irrigation work has been carried on in the United States, especially in the arid tracts. Unfortunately, however, the water supply is only sufficient to irrigate a small fraction of the arid tract, which is approximately three-fourths of a billion acres; but it is pleasing to record that several million acres are under irrigation, and many more may be added.

The problem of arid lands has been solved to some extent by applying a method of cultivation known as "dry-farming." This is the production of crops without irrigation in arid and semi-arid regions; its pioneer was Mr. H. W. Campbell, of Lincoln, Nebraska. The "dry" farmer depends upon the natural rainfall. He does not artificially apply water to his crops, but adopts methods, which enable him to make the best use of moisture from the clouds, or perhaps from underground supplies. The success of "dry-farming" for wheat depends upon four factors :

1. The amount of moisture.

2. The character of the soil.

3. The methods of conserving the moisture.

4. The growing of drought-resistant wheats.

The principles for conserving moisture in "dryfarming" are two. First to keep the surface of the land 
under cultivation loose and finely pulverized. This forms a soil-mulch that permits the rains and melting snows to percolate readily through to the compacted soil beneath, and that at the same time prevents the moisture stored in the ground from being brought to the surface by capillary attraction, and then being absorbed by the hot, dry air. The second is to keep the subsoil finely pulverized and firmly compacted, thus increasing its water-holding capacity and its capillary attraction, and placing it in the best possible physical condition for the germination of the seed, and the development of plant roots.

Water moves in the soil by capillary attraction up as readily as down. To prevent it from rising to the surface, after it has been stored beneath, is the primary object of the loose soil-mulch, which composes the top two inches of soil. This soil-mulch forms an open, porous bed, upon which the rains and snows fall, permitting the moisture to percolate readily through into the compacted ground beneath. The method of preparing the land is as follows: The land is deeply ploughed, the under-soil is packed by a machine called the subsoil packer, and the surface is harrowed and pulverized. In order to obtain the best results, a full year should elapse before the first crop is planted. This season is needed for the collecting and storing of water. In the winter and early spring heavy snows cover the ground. When these melt in the spring, instead of draining off the surface, or evaporating, as they have done for ages, they sink into the reservoir prepared for their reception. As soon as the surface is dry enough, the ground is harrowed over 
again and again to get the soil-mulch into the proper condition. This is repeated after each rainfall until seeding time arrives. The seed is then drilled in just deep enough to place it below the soil-mulch in the moist, compacted soil beneath, causing germination in the quickest possible time. After planting, the farmer continues to harrow over the ground after each rainfall, until the growing crop is too far advanced to permit of this without causing its destruction. No sooner is the crop harvested than preparation begins for the next seeding. The plough follows close behind the harvester, cutting a furrow seven inches deep. Behind the plough follows the subsoil packer. No matter how long a time must elapse before the planting of the next crop, the ground is harrowed over after every rainfall, but never when it is dry. Through winter and summer the persistent and untiring stirring of the soil-mulch is continued, whether anything is planted or not. Constant watchfulness is the price the farmer must pay for good crops.

By this system crops are grown (1) annually, (2) biennially, and (3) a modification or combination of (1) and (2), depending largely on the rainfall, the texture of the soil, the length of the growing season, and the means of disposal of the product. Wheat is one of the most successful crops of the "dry-farming" districts; the "Durum" wheats are the best spring varieties, and "Turkey Red" the best "fall " variety.

There is nothing inimical to irrigation in the "dry" farming" movement. Each has a wide field before it. In many regions it is probable that a combination of irrigation and "dry-farming" methods will be found 
desirable. "Dry-farming" is now used only as a supplement to irrigation farming. What will be the effects of "dry-farming" on future wheat outputs remains to be seen. The uncertainty of crops in certain seasons unless irrigation is used as an aid, the constant watchfulness and care demanded, and the advantages of other undeveloped tracts for wheat-growing over the arid tracts, have all to be considered. While many "dryfarmers" give glowing accounts of their success, and claim that their methods will add millions of acres to the wheat fields of America, many experienced agriculturists are inclined to think that the wheat output will not be materially increased by "dry-farming " methods.

The application of fertilizers to the soil is beneficial in some or all of three ways: (1) It may improve the physical condition; (2) it may improve the action of useful bacteria; and (3) it may supply nutrient materials. Wheat is a delicate feeder, and requires a large amount of soluble nitrogen early in its growth, hence nitrogen is the fertilizer constituent that usually gives the best results. It should, however, be noted that no specific law has been worked out even for a particular soil, from which the fertilizing requirements could be deduced in any exact manner. Fertilizers rarely take the place of efficient methods of cultivation in increasing or maintaining crop yields. The idea now held is that low yields are usually related to the physical condition and characteristics of the soil ; the great controlling factor in the yield of crops is not the amount of plant food in the soil, but is a physical factor, the exact nature of which is yet to be determined. Mr. Whitney, Chief of the Bureau 
of Soils in the United States Department of Agriculture, maintains that he never saw a case of soil exhaustion, which was probably due to the actual removal of plant food. He says that the so-called worn-out soils of the United States are due to conditions, which make the plant food unavailable; and holds that the primary object of fertilizing is the adaptation of soils to any desired crop or crops.

Doubtless commercial fertilizers applied to the wheat fields of America would result in increased yield, but they are in the nature of a speculation. In Europe commercial fertilizers are largely used, but the conditions are vastly different from those existing in America. The price of wheat is higher, therefore the cost of fertilizers is relatively less; and the wheat fields are smaller and intensive farming is possible. Of the fertilizers sold in the United States in 1899 about 70 per cent. was consumed in the North Atlantic and South Atlantic states, in an area lying within 300 miles of the sea-board. Nearly half of the remainder was purchased in the four states, Ohio, Indiana, Alabama, and Louisiana.

American scientific agriculturists believe that commercial fertilizers will prove beneficial and remunerative, when judiciously used in a rotation of crops, and for encouraging the growth of clover, so as to add nitrogen to the soil from atmospheric sources. Commercial fertilizers cannot take the place of farm manures or crop residues, particularly those from clover, for permanently improving the soil. Clover is a plant, which belongs to the class of legumes, and these have the remarkable property of being able to take a large proportion of the 
nitrogen they need for their growth from the air. The careful researches of many eminent scientific investigators have shown that the legumes obtain nitrogen from the air found in the interstices between the particles of soil, through the agency of certain micro-organisms present in the soil. These bacteria, whose special function is the assimilation of free nitrogen, attach themselves to the roots of growing clover, or other legumes, forming thereon small nodules or tubercles. These nodules, swarming with their countless inhabitants, are to be found in sizes varying from a pin's head to a pea, and frequently scattered in large numbers over the roots of the plant. The nitrogen taken in by these microbes, and converted into soluble compounds, is used by the clover, and stored in the tissues of the roots, stems, and leaves. The legumes are especially rich in nitrogen, and though we are unable to say exactly what proportion of this element is taken by them from the air, it is certain that under favourable conditions the greater part is from that source. Besides this addition of nitrogen to the soil, clover ploughed under has the following effects : A large addition of humus is made to the soil, whereby the soil is made more retentive of moisture, warmer, and better aerated, conditions favourable to successful wheat-growing; and an increase is made to the store of available plant food (phosphoric acid, potash, and lime) in the surface soil, taken by the clover in part from depths not reached by the shallower root systems of other plants.

Doubtless one of the most important factors in the usefulness of farmyard manure in wheat tracts is the bacterial flora thus introduced into the soil. 
An important addition to our knowledge of soil fertility was made by Dr. E. J. Russell at the British Association Meeting at Sheffield in September, 1910. Experiments conducted by him and Dr. H. B. Hutchinson at Rothamsted on the part played by micro-organisms other than bacteria in determining soil-fertility gave sufficient evidence to warrant the assumption that soils contain some large organism capable of checking bacteria, and so reducing the productiveness of soils. Mr. A. D. Hall, F.R.S., says that if by the destruction of injurious organisms the bacterial efficiency of the soil is kept up, it is possible to get a very much better duty out of nitrogen applied in fertilizers.

Intensive farming implies scientific farming, and develops as population presses on the means of subsistence. There is evidence that intensive farming is commencing in the oldest settled districts of America, where the farms are becoming smaller, where fertilization is practised, and where crop-rotation has its place.

A good rotation of crops is an essential of scientific farming, and in those parts of America, where the soil has been impoverished by the growth of wheat upon it for many successive years, the system of crops following in rotation would be very beneficial. By crops following in rotation, the land is not robbed of one essential constituent, since different crops take different constituents from the land, and some of these crops may add to the soil an essential constituent for a succeeding crop. This system is more economical than supplying the necessary constituent or constituents by artificial means. Clover and the other members of the legume family should 
always be included in a rotation, which also includes wheat, for reasons previously stated.

American agriculture has till late years (and even now to a great extent this is true) consisted mainly in raising cheap wheat crops. As late as 1902 the United States Department of Agriculture reported that little crop-rotation was practised. The degree of rotation diminishes from east to west, and practically disappears in Kansas. In Canada summer-fallowing is becoming general throughout the North-West. The custom of continuous wheat-growing is very general in Argentina, but the beginnings of rotation are noticeable in the alternation of maize and wheat, and in the practice of growing alfalfa after three or four years of wheat-cropping.

Considerable wheat area is lost in America through carelessness and wastefulness in ploughing or seeding, and in some cases both. Early ploughing has many advantages, but is often neglected. Among its chief advantages are the prevention of the growth of weeds, the conservation of the moisture of the soil, the keeping of the soil in good tilth, the quicker germination of seeds, and the earlier harvests made possible. In the arid and semi-arid parts of America, and in those districts where early frosts occur, it is of high importance for the farmer to plough his land early. Frosts occur in the high latitudes of America in summer, and are primarily due to the absence of mountains along the north of Canada, which allows the cold winds to blow down from the Arctic Ocean over the wheat fields ; these frosts unfortunately occur during the latter half of August, when the wheat is very nearly ripe, and when the long summer has dried up every green 
thing on the face of the prairie. Then, as there is no moisture left to be evaporated, the slightest breeze from the north nips the wheat. The remedies are several: wind-breaks or plantations of trees to shut off the cold winds may be employed, but the most important remedies are early ploughing and seeding, and the use of hardy, early ripening varieties of seed. 


\section{CHAPTER IV}

CLASSIFICATION OF AMERICAN WHEATS, AND THE DIVISION OF AMERICAN WHEAT FIELDS, ON A CLIMATIC AND SOIL BASIS

American wheats may be classified by the season of sowing as Spring Wheats, and Winter or Fall Wheats ; by the firmness of the grain as Soft Wheats and Hard Wheats; by their "strength" as Weak Wheats and Strong Wheats ; by the products for which they are used as Bread Wheats and Macaroni Wheats; and by the colour of the seed as Red Wheats and White Wheats.

From the standpoint of environment it will hereafter be seen that they may be classified as follows :

1. Common Bread Wheats (Triticum vulgare).-(a) The soft winter wheats, vàrying in colour of grain from amber to white.

(b) The hard winter wheats, red grained, usually bearded, and possessing a relatively high gluten content.

(c) The hard spring wheats, red grained, and rich in gluten content.

(d) The white wheats, soft and very starchy, but possessing grains a little harder and much drier than those of the soft winter wheats. They are either "fall" or spring sown, and are sometimes sown at both seasons in the same locality. 
(e) The early wheats, soft or semi-hard, generally amber to red in the colour of the grain, and distinguished by their ability to ripen early.

2. Club or Square-Head Wheat (Triticum compactum).These wheats possess as a rule extremely short heads, and are often squarely formed. The heads are commonly white, but sometimes red, and are either bearded or bald. The grains are usually short, and rather small, white, or red, and often boat-shaped. The peculiar structure of the head allows the varieties to be comparatively large yielders, and this property is of great importance. The tenaciousness of the chaff enables these wheats to be harvested long after ripening without loss from shattering. They are grown as either spring or winter varieties.

3. Durum Wheats (Triticum durum).-Durum wheats possess grains usually very hard and glassy, sometimes rather transparent, yellowish-white in colour, occasionally inclining to reddish, and proportionately rather long. They are the hardest-grained wheats that are known, and most varieties are spring-sown.

4. Emmer (Triticum dicoccum).-Emmer possesses a grain, which is somewhat hard, and is red in colour. The plant is resistant to drought. It gives a good yield of grain, but is chiefly used for forage purposes. It is used in the production of new varieties by hybridization, largely on account of its drought-resisting qualities.

5. Spelt (Triticum spelta). - Spelt possesses grains light red in colour, and the grain is always held tightly within the chaff, and cannot be hulled in threshing. Spelt is used very little for human food, but is generally fed to stock. There are both winter and spring varieties. It 
is used in the production of new varieties by hybridization, chiefly on account of its drought-resisting qualities, and the non-shattering of the grain.

Very small quantities of Spelt and Emmer are grown in America ; they are chiefly found in the dry parts, and breed is one of the dominant factors in determining the quality of the grain.

The vastness of the American continent and its numerous wheat regions make it advisable to consider separately : (1) Canada, (2) the United States, (3) Mexico and Central America, (4) countries east of the Andes ; and (5) countries west of the Andes.

\section{Canada.}

Canada is roughly the same in size as the continent of Europe; part of it lies in the North Frigid Zone, and part in the North Temperate Zone. Its northern boundary is the Arctic Ocean, and its most southerly point lies on nearly the same parallel of latitude as Rome. Naturally, therefore, its climates and soils are most varied. It is possible, however, from the standpoint of soil and climate, to divide the wheat regions of Canada into six divisions :

1. North-Western Canada, including Manitoba, and the greater part of Saskatchewan and Alberta growing strong, hard spring wheats.

2. Southern Alberta growing strong, hard winter wheats.

3. Southern Alberta and South-West Saskatchewan, growing in small quantities Durum wheats, and irrigated 
wheats white-grained, soft and starchy, and hence possessing small gluten content.

4. British Columbia growing white, soft, starchy wheats, usually "fall" sown.

5. Western Ontario growing mainly soft winter wheats ; and

6. Quebec and the Maritime Provinces growing mainly soft spring wheats.

The main wheat-growing region of Canada lies between the Rockies on the west, and the Great Lakes on the east, thus including the prairies of North-West Canada. The late Dr. G. M. Dawson showed that these plains, or prairies, rise gradually from east to west in the form of steps, being 800 or 900 feet above sea-level at or near Winnipeg, while at the foot of the Rocky Mountains they are 4,000 feet or more above sea-level. This ascent is not regular, however, each step having certain-features peculiar to itself.

The prairie soils of Canada are justly noted for their productiveness. They contain, as a rule, large percentages of all the essen ial constituents, and are characterized by percentages of humus and nitrogen far above the average. The prevailing surface soil, speaking generally, is a black, or greyish black loam in which the vegetable matter is well decomposed, and thoroughly incorporated. with the inorganic compounds of the soil. It varies in depth from a few inches to one, two, or even more feet, and over large areas is underlaid with a heavy clay subsoil. This black surface soil occurs in all the hollows of the first and second steps, and occasionally on the higher grounds. The more elevated grounds, 
and the ridges and hills, are generally devoid of it. So far as it has been studied, it seems to be a vegetable formation, which in the lower grounds grew in shallow lakes, ponds, and swamps, accumulating in situ for ages. Dead and decayed water and marsh plants, together with peat and other vegetation growing in moist places, seem to make up the bulk of the deposit. The intermixed fine sand and silt have probably been carried into the swamps and ponds by rain and wind action from the higher and drier grounds surrounding them.

Concerning the prairie soil of the Red River Valley, Dr. G. M. Dawson wrote: "Of the alluvial prairie of the Red River much has been said, but the uniform fertility of its soil cannot be exaggerated. The surface for a depth of 2 or 4 feet is a dark mould, composed of the same material as the subsoil, but mingled with much vegetable matter. Its dark colour is no doubt due in part to the general accumulation of the charred grasses left by prairie fires. The marly alluvium underlying the vegetable mould would, in most countries, be considered a soil of the best quality, and the fertility of the ground may, therefore, be considered as practically inexhaustible."

A knowlecige of the climate of North-West Canada is of considerable importance to-day, for this region is in all probability destined to become, if not the greatest, yet at least one of the greatest wheat-producing regions of the world. Spring and summer are the most important seasons to the wheat growers of North-West Canada.

Throughout the region the spring is short, and the farmer must utilize fully every day from the last days of March until the end of April. By the end of April 
all wheat should be sown in order that the warm, moist days of the early summer may contribute to the germination of the seeds. A study of the diagrams and maps, which accompany this chapter, will show that spring usually opens a little earlier in Alberta, near the mountains, than it does in Manitoba, but that after early in May the more eastern districts become the warmer, and that the average temperature of the three summer months at Winnipeg is some five degrees higher than at Calgary and Edmonton. During May and June the temperature rapidly rises, and from the middle of May until the end of July the heaviest rainfall occurs. During July and August bright hot days are frequent, and temperatures exceeding $90^{\circ} \mathrm{F}$. have been recorded. It is important to note that in Manitoba 50 per cent., and farther west more than 62 per cent., of the total precipitation for the year falls between May and August; and June is the month of heaviest rainfall — just the very period when moisture is required for the growing wheat crop. The normal annual precipitation of Manitoba is approximately 22 inches, of Saskatchewan 16 to 17 inches, and of Alberta 17 to 18 inches.

A fact of peculiar interest is that the summer season in the basin of the Mackenzie River is nearly as warm as in Alberta. At Edmonton and Calgary the mean summer temperature is $59^{\circ} \mathrm{F}$., at Dunvegan $58^{\circ} \mathrm{F}$., at Fort Chippewyan $59^{\circ}$ F., and at Fort Simpson $57^{\circ}$ F. The explanation lies chiefly in the fact that the insolation, or heat received from the sun, scarcely varies about midsummer between the parallels of latitude 40 and 60 degrees; the larger number of hours the sun is above the horizon in 
the higher latitudes very nearly balancing the effect of less direct solar radiation. Southern Alberta has a much milder winter than the rest of North-West Canada, and this is largely due to its position, and the drying effect of the Chinook winds. The cold becomes greater to the eastward, thus the average winter temperatures (December to March) are as follows : Calgary, $17 \cdot 1^{\circ} \mathrm{F}$.; Medicine Hat, 16. $4^{\circ}$ F.; Qu'Appelle, $5^{\circ}$ F.; Winnipeg, 1. $7^{\circ}$ F. Northward the change is even more rapid, and in strong contrast to the small variation during the summer : Calgary, $17 \cdot 1^{\circ}$ F. ; Edmonton, $13^{\circ}$ F. ; Dunvegan, $1^{\circ}$ F. ; Fort Chippewyan, $-5^{\circ} \mathrm{F}$.; and Fort Simpson, $-13^{\circ} \mathrm{F}$. A feature of the climate of Alberta is the effect produced by the Chinook winds in keeping the prairies almost bare of snow during the winter, and quite bare in the early spring. The Chinook winds are moist ocean winds, which are forced up the western slope of the Rockies, and, owing to the condensation of moisture, do not cool as rapidly as they otherwise would, and subsequently, mechanical heating by compression, as they descend the eastern slopes, brings them to the prairies comparatively warm and dry.

The average yearly snowfall of North-West Canada is from 50 to 55 inches, but the frosts, which come before the snow, make it impossible to grow fall wheats, except in the mild winter climate of South Alberta.

A point of great importance in Canada's climate is the percentage of sunshine throughout the year. Nearly all parts of the Dominion have an annual percentage of over 40, and a summer percentage of between 53 and 59 ; thus, Canada compares very favourably with 
the southern parts of England with a normal annual percentage of 36 .

The relative humidity of the air for the year varies from 55 to 65 per cent. over the region, but during the later stages of the growth and ripening of whoat it is less, and the combination of comparatively dry air and bright sunshine has much to do with the excellent quality of the grain.

The semi-arid area of North-West Canada, 80,000 square miles in extent, is bounded on the south by the International Boundary, on the east and north by a line commencing at the intersection of 102 degrees west longitude with the International Boundary, and running from thence north-westerly to $51^{\circ} 30^{\prime}$ north latitude, and thence west to the Rocky Mountains; and on the west by the Rocky Mountains. The causes of the aridity are not as yet completely known; topographical relief, the Chinook Wind, and atmospheric movements doubtless all play their part. Over by far the greater part of the semiarid region the soil is rich; it lacks only moisture.

North-West Canada plainly possesses almost ideal conditions for the growth of strong wheats. Its climate is almost a perfect "steppe" climate ; an abundant rainfall occurs in the early stages of the growth of wheat; bright, sunny weather prevails towards harvest time, and the heat and dryness become extreme. The soil is of exceptional richness in humus and is retentive of moisture and heat; naturally, therefore, some of the finest wheats of the world are grown in this region, and command the highest prices in the wheat markets.

Another advantage enjoyed by this region of Canada 
is that it lies farther north than the other wheat regions of America, and this aids greatly in the production of high-grade wheats, and their perfect development. In this connection the effect of sunshine must receive attention. In $58^{\circ} 5^{\prime}$ north latitude sunshine becomes as much as eighteen hours per day in the summer season. Dr. William Saunders reported in 1908 that some of the finest wheat he saw was sent to him from Fort Vermilion. The wheat which won the first place at the World's Columbia Exposition in 1893 was grown in the Peace River Valley, near the northern boundary of Alberta.

Alberta "fall" wheats, especially Alberta Red and Kharkof, rank very high in quality. Climate is the main factor in their production, though soil and breed also exert their influence. Southern Alberta may lay claim to possessing some of the finest winter wheat lands in America, for the rainfall is sufficient to mature the grain, is far from being excessive, and it occurs chiefly during the growing season. Again the prevailing clearness and dryness of the atmosphere, and the preponderance of sunny and warm days in summer are of great import.

Southern Alberta and South-West Saskatchewan, lying south of the main line of the Canadian Pacific Railway, have only a small average annual rainfall, though in some years it may be sufficient for the growth of wheat by ordinary farming methods ; it is now, however, recognized that the future of this region depends on "dryfarming " and irrigation methods. The soil of most of this region is good, and it has not been subjected to the leaching action of heavy rains. Dr. William Saunders 


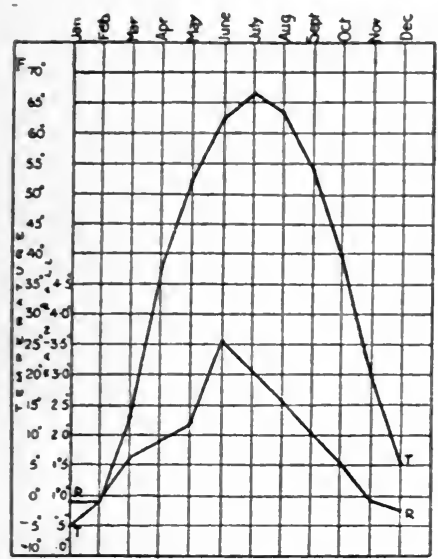

WinNipeg: "Steppe" climatehard, strong spring wheat.

$\mathrm{T}, \mathrm{T}=$ Temperature curve $; \mathrm{R}, \mathrm{R}=$ rainfall curve ; $10^{\prime}$ snow $=1$ " rain.

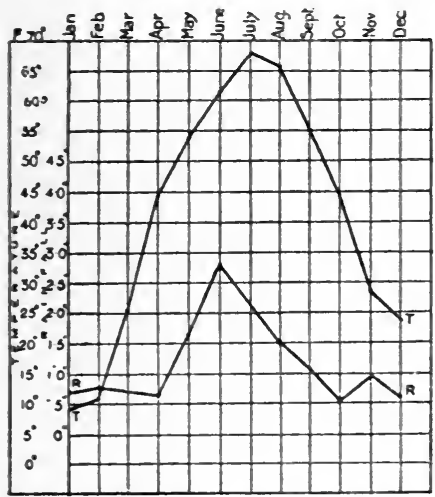

Medicine Hat: Durum wheat and "dry-farming."

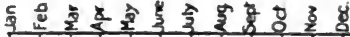

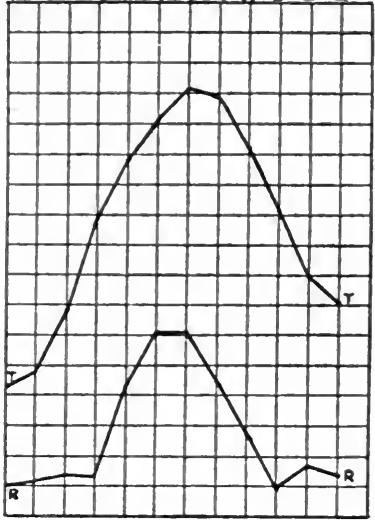

CALGARY : Hard winter wheat.

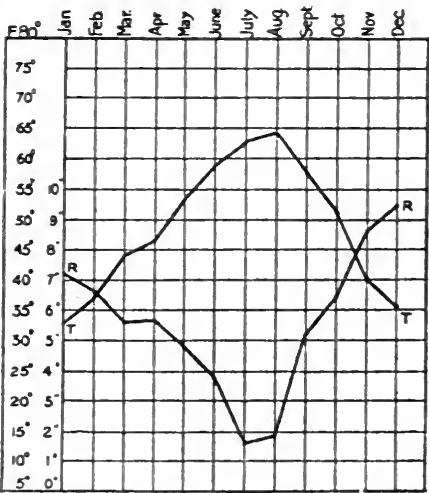

Agassiz, B.C.: White soft wheat.

Fig. 1.-Rannfall and Temperature Curves, Canada.

says that this semi-arid region is, in some respects, more favourable for wheat-growing as regards climate and rainfall than are those parts of the United 
States, where "dry-farming" now seems to be fairly successful.

The climate of British Columbia, as a whole, presents all the conditions, which are met with in European countries lying within the Temperate Zone. The coast region is characterized by its copious rainfall, resulting from the contact of the moisture-laden winds from the Pacific with the Coast Range. The change in climate between the western and eastern sides of the Coast Range is decidedly abrupt. The Pacific winds, deprived of much of their moisture in ascending the western slopes of the mountains, become drier and warmer when flowing eastwards, or passing down to lower levels ; hence the interior plateaux between the Coast and Selkirk Ranges possess a relatively dry climate; the summers are warmer and the winters colder than in the coast districts. March is distinctly a spring month in all the lower levels of British Columbia. In the more southern divisions the mean temperature of April corresponds very closely with that of the same month in England. Meteorological observations extending over a series of years are only available for the Lower Fraser Valley. There spring opens early, the summers are warm, and the winters, which are usually mild and rainy near the coast, increase somewhat in severity with increasing distance from the sea. At Agassiz the average mean temperature for January is $33^{\circ} \mathrm{F}$., and for July $64^{\circ} \mathrm{F}$., with a mean daily range of $10^{\circ} \mathrm{F}$. in the former month, and of $26^{\circ} \mathrm{F}$. in the latter; the lowest temperature on record is $13^{\circ} \mathrm{F}$., and the highest $97^{\circ} \mathrm{F}$. Frost seldom occurs as late as May, and there is no record of any during the summer months. 
The annual rainfall is 67 inches, two-thirds of which fall between the beginning of October and the end of March. The annual average relative humidity of the air varies from 70 to 80 per cent. in the humid parts, and in the drier parts from 50 to 70 per cent.

The surface deposits of British Columbia are somewhat different from those of the Prairie Provinces. The black clay or vegetable deposit is rarely met with ; the materials consist largely of gravels, sands, silts, and clays. In the valley of the Fraser River, however, some of the meadows in its lower reaches exhibit a black loamy soil.

It is evident that the main factors deciding the softness and starchy nature of the wheats of this region are the rainfall, the humidity of the air, and the small amount of humus in certain of the soils. Till recently the growing of wheat in British Columbia was discouraged, as it was thought that the land could be put to more profitable uses, and, as a consequence, the area under wheat has been small. There is an excellent prospect that the future will see great increase in the wheat acreage; the country which will be traversed by the Grand Trunk Pacific Railway is proving to be a first-class wheat-growing district. Excellent samples of wheat have been received from the Nachaco, Bulkley, Kitsumkelum, and other valleys. There are many tracts in British Columbia where crops may in the future be produced under " dryfarming" methods. Among the few isolated cases of "dry-farming" now existing may be mentioned that carried on at the Commonage near Vernon, and that on the uplands near Midway.

The eastern wheat-fields of Canada are her oldest, but 
the time of their greatest prosperity is past, and mixed farming is largely carried on now; yet this region is the second in importance in Canada for wheat-growing.

The Ontario farmer desires a winter with plenty of snow and steady cold, for these are factors leading to success in grain-growing. A considerable proportion of the precipitation of Eastern Canada falls as snow. At Montreal the average of the period 1870-1885 was nearly 120 inches; at Toronto the average of forty-four years was 70 inches ; and even in the far south of Ontario the average of fourteen years was 57 inches. The great advantage of the snow as regards wheat culture is that it protects the ground against severe frosts, and accordingly winter or "fall" wheats can be grown.

The snow usually begins to melt in March, and spring commences early in April or the end of March; and between the middle of May and the middle of September Southern Ontario is included between the same isotherms as the south of France; it is only after a long autumn that winter sets in about the beginning of December. The summer months are distinctly warmer than in England. The annual precipitation of the whole of Ontario lies between 30 and 40 inches, and is fairly distributed throughout the year. The summers in Quebec are comparable with those of Ontario, and the rainfall ranges from 30 to 45 inches annually. Spring in the Maritime Provinces is usually a little later than in Ontario and Central Canada, but the summer lingers longer. The average annual precipitation of these provinces is between 40 and 45 inches, except along the southern and eastern coast-lines of Nova Scotia, where it is nearly $\mathbf{5 5}$ inches. The average annual 
relative humidity of the air varies from 65 to 80 per cent., being highest on the coastal and lake districts.

Winter wheats are grown mainly in Western Ontario on account of its fairly mild winter, its early spring, and its comparatively great snowfall. Quebec also grows winter wheats, but the crop is not comparable with her spring wheat output. The Maritime Provinces, Quebec, and Eastern Ontario, grow spring wheats ; in the Maritime Provinces "fall" wheats are the exception. Climatic

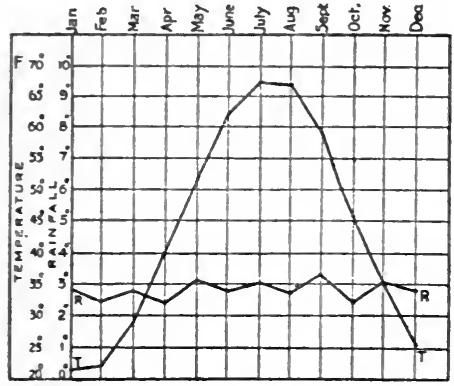

Tononto: Soft winter wheat.

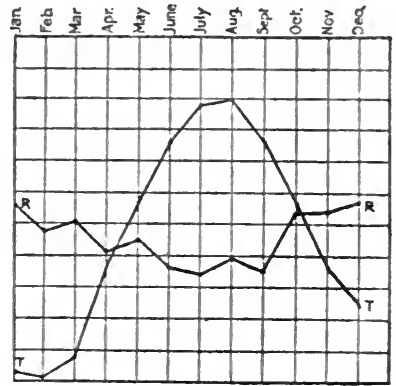

HALIFAX : Soft spring wheat.

Fig. 2.-Rainfall and Temperature Curves, Canada.

factors are more favourable for the growth of spring wheats.

On such a vast extent of territory as Eastern Canada soils of great variety are found, and of different degrees of mechanical consistency; but the most successful wheatgrowing is carried on where the soil is a clayey or sandy loam. The soil of the Maritime Provinces is more suited to the growth of oats and barley than to wheat.

The softness of the grain of both the "fall" and spring varieties of wheat grown in Eastern Canada must be attributed in the main to the rainfall and the humidity 
of the air, and in the case of the winter wheats to the long period of growth also.

The chief varieties of wheat grown in Canada are :

\begin{tabular}{|c|c|c|c|c|}
\hline $\begin{array}{l}\text { North-West } \\
\text { Canada. }\end{array}$ & Alberta (South). & $\begin{array}{l}\text { Alberta and } \\
\text { Saskatehewan } \\
\text { (Arid). }\end{array}$ & $\begin{array}{c}\text { British } \\
\text { Columbia. }\end{array}$ & $\begin{array}{l}\text { Eastern } \\
\text { Canada. }\end{array}$ \\
\hline $\begin{array}{l}\text { Spring Wheats, } \\
\text { hard and } \\
\text { strong: } \\
\text { Red Fife. } \\
\text { Stanley. } \\
\text { Preston. } \\
\text { White Fife. } \\
\text { Blue Stem. } \\
\text { Club Wheats } \\
\text { (a low percent- } \\
\text { age). }\end{array}$ & $\begin{array}{l}\text { Fall Wheats, } \\
\text { hard: } \\
\text { Alberta Red. } \\
\text { Kharkof. } \\
\text { Soft : } \\
\text { Dawson's Gol- } \\
\text { den Chaff. } \\
\text { Odessa. } \\
\text { Claw s on's } \\
\text { White. } \\
\text { Early Genesee } \\
\text { Giant. }\end{array}$ & $\begin{array}{l}\text { Durum Wheats: } \\
\text { Kubanka. } \\
\text { Fuleaster. } \\
\text { Turkey Red } \\
\text { ("Fall "). } \\
\text { Irrigated Wheats: } \\
\text { Sonora. } \\
\text { Felspar. }\end{array}$ & $\begin{array}{l}\text { White Wheats : } \\
\text { Sonora. } \\
\text { Blue Stem. }\end{array}$ & $\begin{array}{c}\text { Spring and Fall } \\
\text { Wheats, soft: } \\
\text { Red Fife. } \\
\text { White Fife. } \\
\text { White Russian. } \\
\text { Dawson's Gol- } \\
\text { den Chaff. } \\
\text { Early Genesee } \\
\text { Giant. } \\
\text { Turkey Red. } \\
\text {. }\end{array}$ \\
\hline
\end{tabular}

Perhaps the most typical wheat of Canada is Red Fife. It was introduced into Canada in 1842 by Mr. David Fife, who happened to obtain one kernel of it mixed with a quantity of wheat, which came to him from Dantzig via Glasgow. Red Fife kernels are red, inclined to pale rather than dark red, and are of medium size, but somewhat short. Red Fife is remarkable for its productiveness, for its high quality, and for its power of adapting itself to the varying conditions of soil and climate.

Winter wheats in Canada are sown in August and September, and harvested in the following July and August. The spring wheats are sown as early as possible in the spring, usually April, and harvested in the following August. In Eastern Canada, where the snowfall is heavy, and often packed by thaws, the farmer waits until the snows melt, and the frost is out of the ground, before commencing spring seeding. Not so in North-West Canada, for the snow soon goes, being light and never 

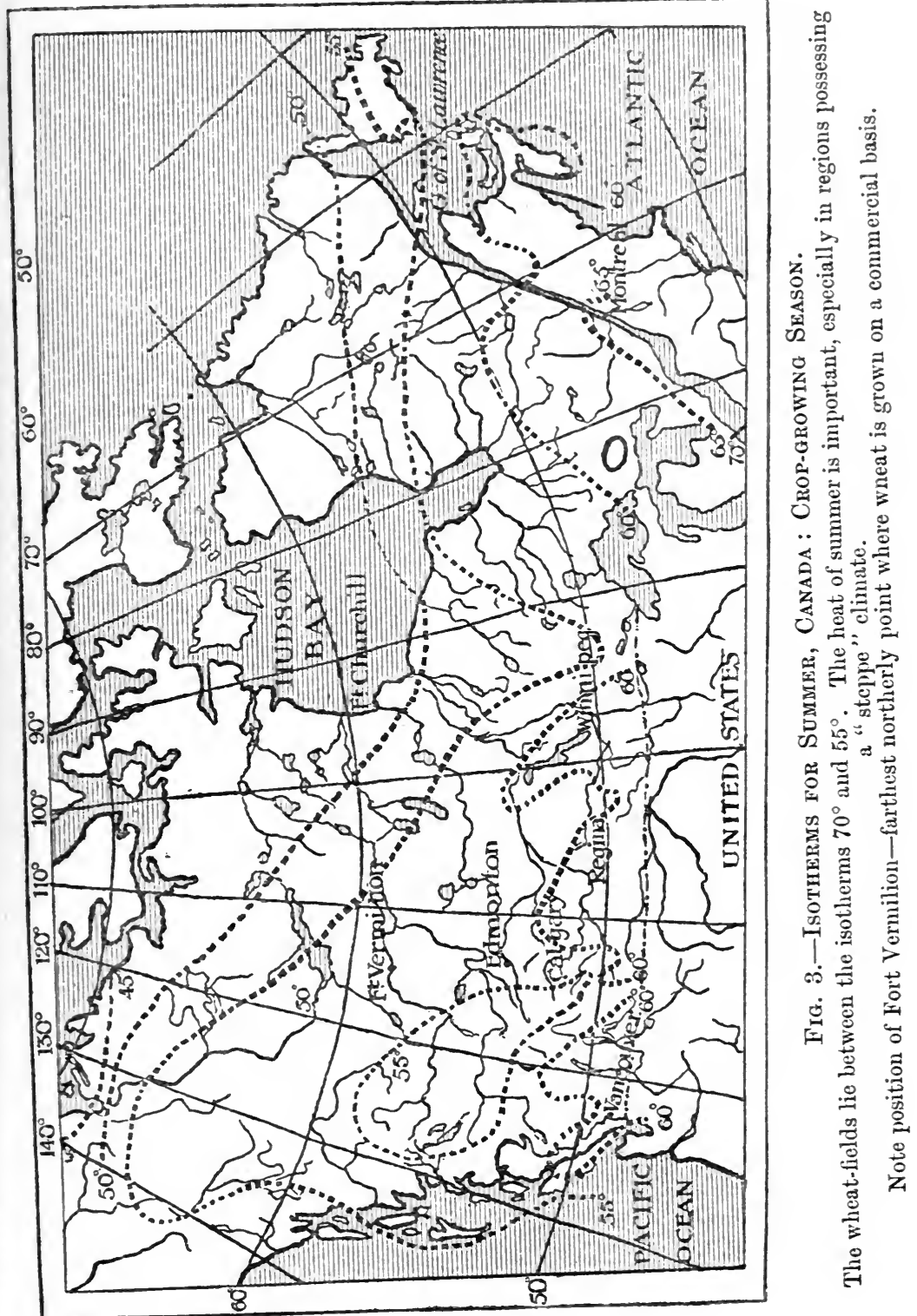


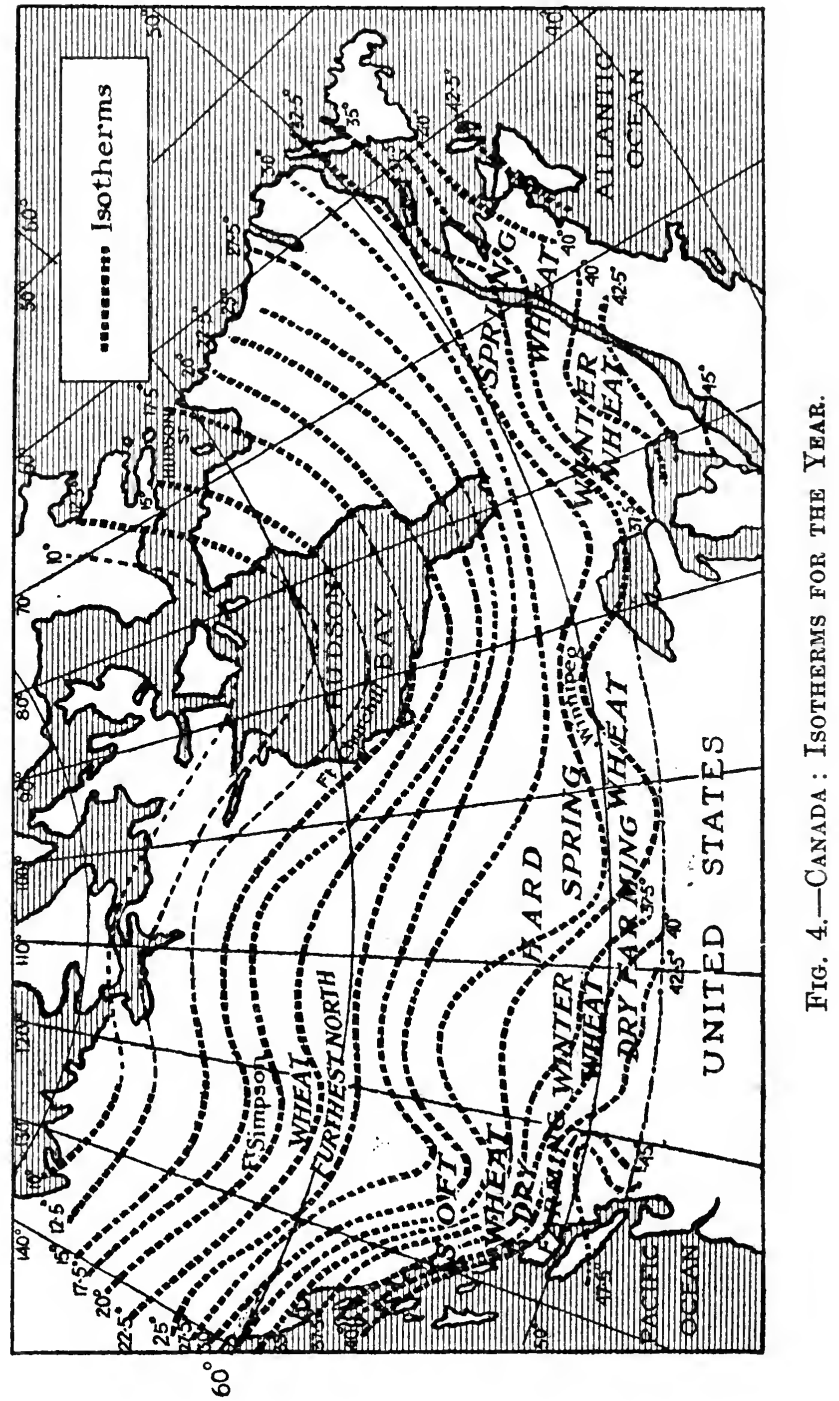




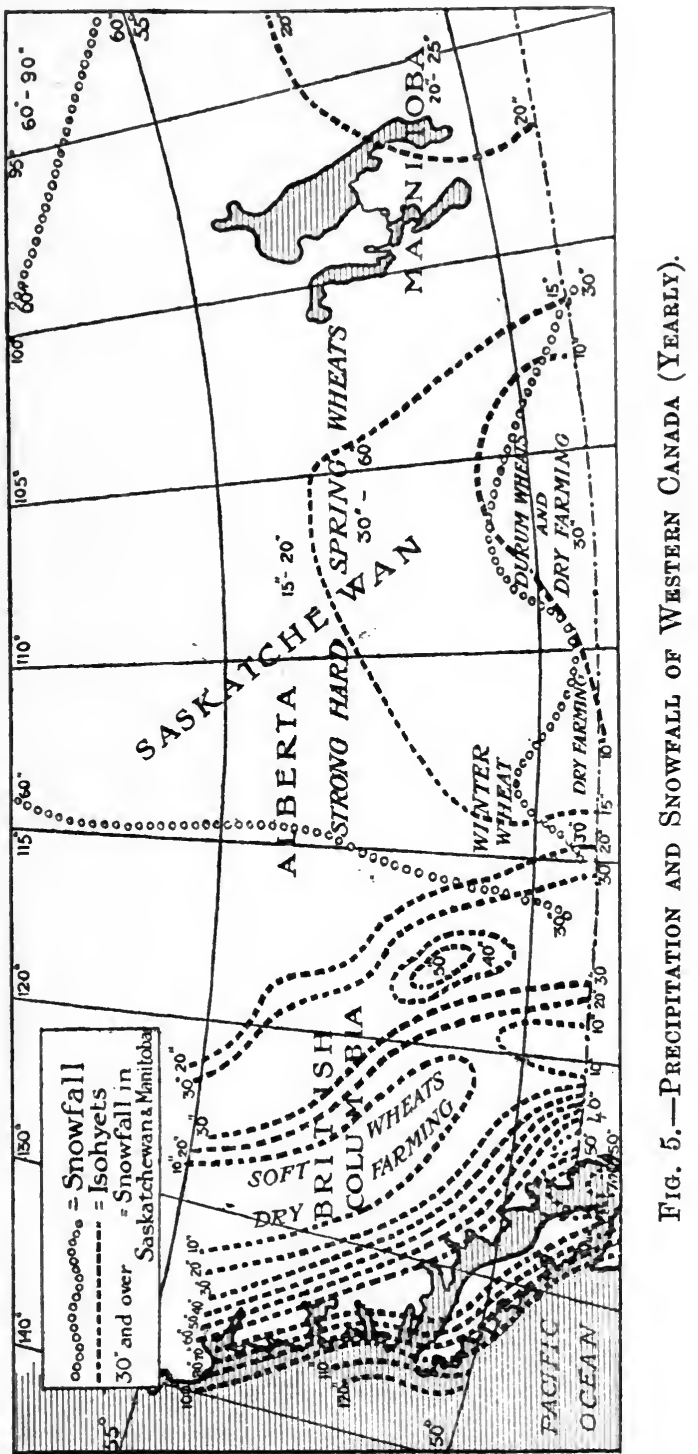




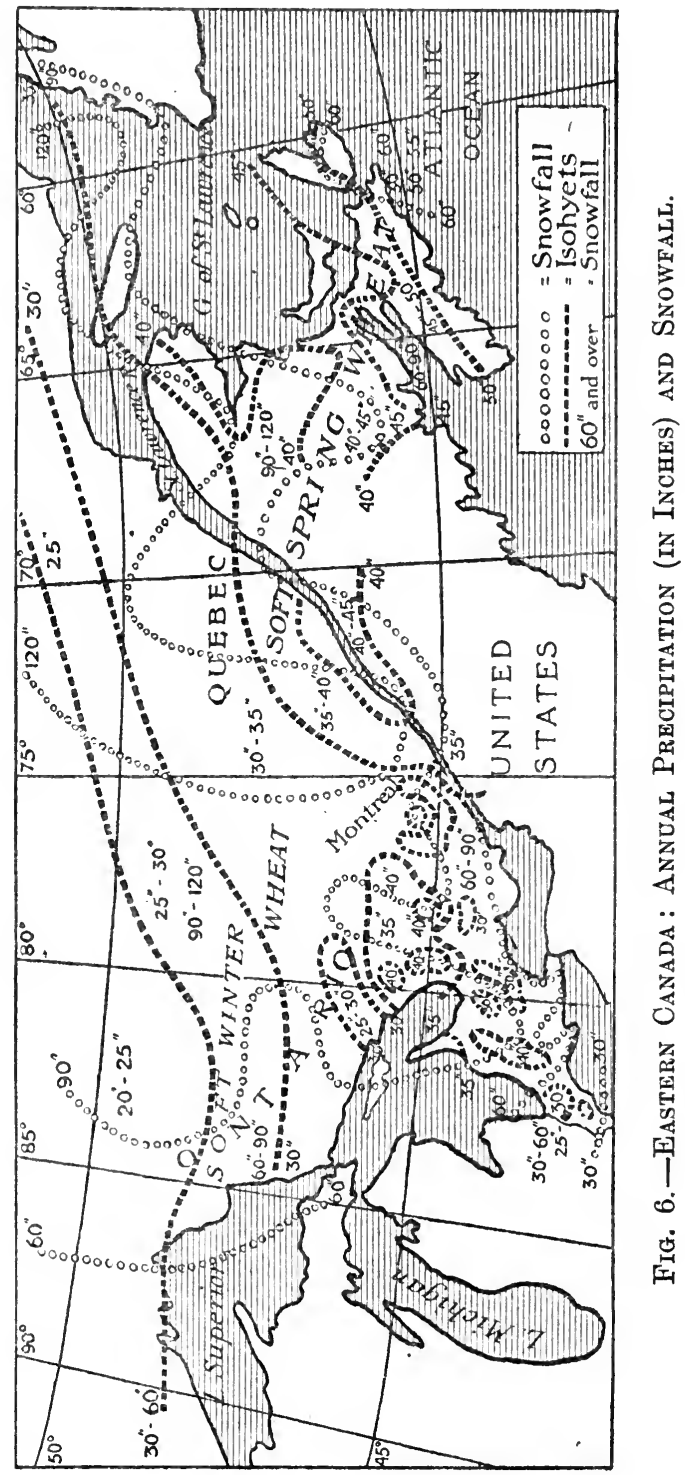


packed. As soon as 6 inches of the soil are thawed the grain is sown; nor does the farmer trouble about the frost coming out of the ground. As the frost relaxes under the warm sun, the moisture resulting feeds the young roots, and they are provided with an excellent foraging ground.

Wheat growers in the Canadian North-West would do well to consider one significant fact in the history of the wheat movement-namely, that from twenty-five to thirty years of continuous wheat-growing without fertilization reduces virgin soils to such an extent, that both the yield and the quality of the wheat are greatly reduced.

Canada's present needs in her wheat fields, when considered from the standpoint of environment, are-

1. Early-ripening varieties of wheat to avoid early autumn frosts.

2. Cold-resisting varieties of wheat to extend the wheat-fields farther north.

3. The growth of leguminous crops, summer fallowing, and the application of farmyard manure and other fertilizers to soils depleted of their nitrogen constituents.

4. The breeding of new wheats of higher gluten contents suitable for the soft-wheat districts, in order, if possible, to raise the grade of the wheats of the East and West of Canada.

5. The introduction of Durum wheats into the semi-arid districts of Alberta, Saskatchewan, and British Columbia. 


\section{The United States.}

This country consists of three main elements :

1. On the west the Pacific Highland, a broad area of lofty mountain country extending from north to south, and 1,000 miles wide in parts.

2. On the east the Atlantic Highland (the Appalachian Mountains and the Alleghany Plateau), with its coastal plain.

3. The Great Central Plain, which forms the basin of the Mississippi-Missouri River.

The Pacific Highland includes the Rocky Mountains and the Coastal Mountains; in the north the latter bear the name of the Cascade Mountains, and in the south the Sierra Nevada. These chains, as well as the Rocky Mountains, rise from a lofty and dry plateau. Beyond the Sierra Nevada lies the Coast Range enclosing the beautiful valley of California. Between the Rocky Mountains and the Sierra Nevada, there is an area of over 210,000 square miles, called the Great Basin it is an area of inland drainage containing parts of the states of Utah, Nevada, California, Idaho, and Oregon. This region is arid; the rainfall in places is on the average only 5 inches in the year, and almost all is lost by evaporation. Its vegetation is scanty, and its most typical plant is the sage-bush.

The Appalachians extend in a general north-east, southwest direction from Northern Alabama and North-West Georgia to New England. The elevation of the plain from which these mountains rise is about 1,000 feet in Georgia, Alabama, and the Carolinas, and less than 400 feet in New England. The southern end of the system is different 
in character from that of the northern. It contains the largest areas of land over 5,000 feet in altitude east of the Mississippi, and it is distinctly a mountain mass rather than a series of isolated mountains, and north and south ridges, as in Northern New York and Northern New England.

The Great Plains of the United States may be divided up into the Gulf Plains, the Prairies, the High Plains, and the Lake Plains. The prairies are wide, open, treeless plains ; they are rather smooth land, with shallow valleys, but some are lower and some are higher. Their extent is from Mexico to the Great Lakes, being about 1,400 miles in length from north to south, and 500,000 square miles in area. Rising gradually westwards the prairies merge into the High Plains, which rise between the Arkansas and Platte Rivers to the height of 6,500 feet above sealevel, and end abruptly at the foot of the Rockies. The Gulf Plains lie along the Gulf of Mexico, but on account of the climate and soil but little wheat is grown on them.

The United States lies between 25 and 49 degrees north latitude, and possesses a great variety of climate, ranging from arid to extreme humid, and from warm temperate to cold temperate. The main factors deciding its climate are the influence of the adjacent oceans, the heat received from the sun, and the general arrangement of the land.

On the basis of temperature the United States divides approximately into three regions :

1. Warm regions, having an annual mean temperature of $60^{\circ} \mathrm{F}$. and above, embrace the southern portion of North Carolina, South Carolina, Georgia, Florida, the Gulf States, the south-west portion of New Mexico, 
Southern Arizona, and the greater part of California, excepting always the mountain districts.

2. Temperate regions, having an annual mean temperature between $50^{\circ}$ and $60^{\circ} \mathrm{F}$., embrace the greater portion of the Middle Atlantic States, the Ohio Valley, Tennessee, the southern portion of Indiana and Illinois, all of Missouri, Kansas, Oklahoma, and South-West Colorado, as well as most of the Northern Pacific Coast States.

3. Cold regions, having an annual mean temperature of $40^{\circ}$ to $50^{\circ} \mathrm{F}$., embrace the northern tier of States, including the northern portions of Indiana, Illinois, all of Iowa, Nebraska, South Dakota, Wyoming, and the mountainous districts of the West.

The rainfall depends largely on the land forms. The winds blowing westward from the Pacific drop their moisture as rain on the western mountains, and reach the Great Basin as dry winds. They are forced to rise again over the Rocky Mountains, and being further chilled by the increased elevation, they drop the rest of their moisture, and sweep down on the Great Plains as dry winds. Along the Pacific Coast the rainfall is in places over 60 inches per annum, in the Great Basin under 10 inches, along the Rockies 30 inches, and on the High Plains at the foot of the Rockies it falls to between 10 and 20 inches. In the extreme south the inflowing winds bring summer rains, which fall over the whole of the Central Plains. Depressions pass over the plains in winter, drawing moist air from the Gulf of Mexico, and causing winter rains. California has a Mediterranean climate of dry summers and mild winters. On the prairies the rainfall varies from 18 to 30 inches. Eastwards 
the rainfall increases, until the whole of the Appalachian belt has a rainfall of from 50 to 60 inches, and all the Atlantic coastal plain has a rainfall of over 40 inches. In the eastern part of the United States the rainfall is ample for successful wheat culture, although it is irregular, much more coming in certain years than in others. It rarely happens that the country east of the 97 th meridian suffers from an insufficient rainfall for the needs of crops. Between the 97th and 100th meridians, however, lies a belt of country, where in certain years the rainfall may be sufficient for wheat-growing, but is generally far from being sufficient. In the past the farmer's efforts have been defeated, but there is hope now that these regions may be developed to some extent by "dry-farming " and irrigation methods.

The types of rainfall in the United States have been divided into the following:

1. The Pacific Type, characterized by a wet season, extending from October to March, and a practically rainless summer, except in Northern California, and parts of Oregon and Washington. About half of the yearly precipitation comes in the months of December, January, and February ; the remaining half is distributed throughout the seven months-September, October, November, March, April, May, and June.

2. The Sub-Pacific Type obtains over Eastern Washington, Idaho, Nevada, and Utah. There is not a steady diminution in the winter precipitation as spring approaches, but rather an increase, which culminates in the late spring months. This fact is of very great importance to wheat interests, in deciding whether the rainfall is 
sufficient for the growth and maturity of the crop or not. In the latter case, the rain comes at a time when most needful for irrigation.

3. The Arizona Type prevails in Arizona, New Mexico, and a small southern portion of Utah and Nevada. Thirty-five per cent. of the rainfall occurs in July and August, and May and June are the months of least rainfall.

4. The Plains Type obtains over the Dakotas, Minnesota, Wisconsin, part of Michigan and Illinois, all of Iowa, Nebraska, and Kansas, and the greater part of Missouri. Scant winter precipitation occurs over the most northern states, and moderately heavy rains during the growing season. With increase of latitude there is a decrease in the winter precipitation. Thunder-showers are a characteristic feature of the summer precipitation.

5. The Gulf Type is characterized by its fairly uniform precipitation throughout the year.

6. The Southern Appalachian Type has as its chief characteristic a marked winter and spring rainfall. From Virginia to Florida, however, July, August, and September, are rainy months.

7. The Middle Atlantic and New England Type is noteworthy for its uniformity of precipitation; and

8. The Lake Region and Ohio Valley Type is very like that of the Plains.

As previously stated, there are many varieties of soil in the United States, but the soil series, which are most largely identified with wheat production, are the Miama and the Marshall, which occupy the great central region of the Upper Mississippi Valley, in which the bulk of the 
wheat crop of the United States is produced. The chief soils of the north-western states, upon which wheat is produced, are the Marshall loam, silt loam, and clay loam. Through Illinois, Wisconsin, Michigan, Indiana, and Ohio, the Miama series are the dominant type, and the most important wheat soils are the Miama clay loam and the Miama black clay loam. The former occupies immense areas of country of level topography, and is well adapted to the use of machinery. In general, it may be said that the greater part of the wheat crop of the United States is produced on soils of glacial origin, and, in the main, they have either been formed from glacial till or glacial material reworked by wind or stream action. The Marshall series of soils, predominant in the north-western states, are dark-coloured, due to the presence of a very large amount of organic matter. They are also generally rich in lime, running from 2 or 3 per cent. to 10 or 15 per cent., and, in some cases, certain strata of the soil may be as rich as 50 per cent. in lime.

In the famous Red River Valley, lying in the East Dakotas and Western Minnesota, the soils are the result of glacial deposits, and are generally of a heavy clay, and less rich in lime than the upland soils. They are at present very poorly drained, and considerable loss ensues from this disadvantage.

Other series of soils in this section of the country, upon which wheat is more or less grown, are the Clyde series.

Originally of a swampy nature, they have now been drained, and wheat is cultivated on them. Owing, however, to the large amount of organic matter in these soils 
wheat is liable to go down, and consequently the grain suffers.

The Superior series along Lake Superior are somewhat used for wheat production. In the valleys of all the larger streams occurs a gravelly loam or silt loam, generally of a dark colour, upon which some wheat is produced, but, as in the Clyde series, wheat is subject to lodging on account of the large amount of organic matter in the soil.

In the semi-arid regions in Kansas, Nebraska, and Oklahoma wheat is produced upon a variety of soils, some of which are the Crawford series and the Oswego series; the former being derived from the decomposition of limestones, and the latter from shales.

In the eastern section of the country in Pennsylvania, Maryland, and Virginia, the Hagerstown series are prominent wheat-producing soils. These soils are the result of the weathering of the Cambro-Silurian limestones, which form the floor of the valley. Farther south, in the Piedmont section, the Cecil soils frequently produce wheat with considerable success. The Cecil soils are heavy clay, and clay loams derived from the weathering of granitic and crystalline schist rocks.

The soils of Idaho and Eastern Washington, producing phenomenal yields of wheat, are the result of the weathering of extensive sheets of basaltic lava. In the great Central Valley of California wheat is grown on soils of ancient marine and lacustrine sediments. It would not be possible to say that any one soil in the United States is peculiarly, and especially, suited to the production of wheat; but it is possible to say that varieties of wheat 
exist, or may be bred, which will be suited to the different conditions of climate and soil, which occur throughout the temperate portions of the country.

A stuady of the foregoing climatic and soil conditions, together with the maps and diagrams accompanying this chapter, enables us to divide the wheat regions of the United States (as Carleton has done in his work, "The Basis for the Improvement of American Wheats ") into eight main districts, each having its own peculiar type of wheat. No country, perhaps, shows more the great effects of climate upon the wheat plant and grain than the United States. Climate is clearly here the prime factor in producing the type of wheat.

The eight wheat districts are as follows :

1. The soft wheat region, including the New England and the Middle Atlantic States.

2. The semi-hard winter wheat region, including the North Central States.

3. The southern wheat region, including the northern part of the Southern States.

4. The hard "strong" spring wheat region, including the Northern States of the Plains.

5. The hard winter wheat region, including the Middle States of the Plains.

6. The Durum wheat and "dry-farming" region, including a part of the Southern States of the Plains.

7. The irrigated wheat and "dry-farming" region, including in general the scattered portions of the wheat area in the Rocky Mountains and Basin States.

8. The white wheat region, including the larger part of the Pacific Coast States. 
The soft wheat region includes approximately New York, Pennsylvania, New Jersey, Maryland, Delaware, and portions of Virginia, West Virginia, and Eastern Kentucky, also the New England States, which produce wheat to any considerable extent. The wheats of this region are characterized on the whole by their softness, and contain a large amount proportionally of starch; occasionally, however, the wheats incline to semi-hard. The grains are usually yellowish white or amber in colour, but sometimes they are quite red.

The chief reasons for the softness of the grains are mainly climatic and soil conditions. In summer the climate is too moist and cool, the average amount of sunshine is but moderate, and the humidity of the air is great, being 75 to 80 per cent. ; the yearly rainfall averages from 40 to 50 inches. The soil, especially if not fertilized, does not possess the necessary alkali, phosphate, and humus constituents required for the production of hard, glutinous wheats. In New York and Pennsylvania it is pleasing to record that by means of the plentiful application of fertilizers and rigid seed selection, a large amount of good wheat is grown, but, on the whole, this region is of minor importance.

In the most northern portions of this region spring sowing is, as in Eastern Canada, almost entirely practised ; a better plan would seem to be the growing of hardy winter wheats after rigid seed selection and wheat breeding.

The chief varieties of wheat grown are : Fultz, Early Genesee Giant, Early Red Clawson, Mediterranean, Blue Stem, and Jones's Winter Fife. They are usually sown 
in September and early October, and reaped in late June and early July.

The needs of the wheat-growers in this section are :

1. The growing of harder grained and more glutinous varieties of wheat.

2. The growing of wheats of earlier maturity and rustresisting, for in such a moist climate rust is apt to be prevalent.

3. The application of fertilizers to the land.

4. The breeding of hardier winter varieties for the northern sections.

The semi-hard winter wheat district includes Ohio, Indiana, Illinois, Michigan, and a small part of Wisconsin. The wheats produced are of a medium quality, but, on the whole, this region must be considered as one of the most important wheat regions of the United States. The grains of the wheats are generally semi-hard, and rather reddish in colour. During the last thirty years the tendency has been towards the use of harder red wheats, and also of a larger proportion of winter as compared with spring varieties. The advent of the roller-milling process is largely, though not solely, responsible for this. The area under winter wheat now includes practically all Michigan and Illinois, and part of Wisconsin.

A fact worthy of notice is that the climate approaches the "steppe," and the rainfall is less than the soft winter wheat region, averaging 30 to 35 inches annually. Climatic factors are the main ones in deciding the nature of the grain, though wheat-breeding is playing its part at the present time.

The chief varieties of wheat now grown are: Fultz, 
Early Red Clawson, Dawson's Golden Chaff, and Valley. They are sown in September, and harvested in late June and in July.

The wheat-growers of this district need :

1. The breeding of wheats of harder grain, and of rustresisting qualities ; and

2. The introduction and breeding of wheats of hardier winter varieties.

The southern wheat district is of very minor importance ; in area it includes the larger portion of Kentucky, Virginia, West Virginia, and North Carolina, all of Tennessee, and portions of South Carolina, Georgia, Alabama, Arkansas, and Missouri. By far the most important states are Kentucky, Missouri, Tennessee, and Virginia. The wheats at present grown are either soft or semi-hard, and usually amber or reddish in colour, and are either bearded or beardless.

In a great portion of this region the soil is poor for wheat-growing, and the combination of mild annual temperature, great rainfall (55 to 60 inches per annum), and high relative humidity of the air, is not conducive to success. Though suffering under these disadvantages, this district could raise its status by paying attention to wheats of early maturity and of rust-resisting qualities, to wheats resistant to late spring frosts, and to the application of fertilizers.

The chief varieties grown are : Fultz, Fulcaster, Rice, Everett's High Grade, and Purple Straw. They are sown in late September and early October, and harvested in June.

The hard "strong" spring wheat area comprises the 
states of Minnesota, North Dakota, South Dakota, the larger part of Wisconsin, portions of Iowa and Nebraska, and small portions of Montana and Colorado. Here are grown the highest grade of spring wheats, and as in Central Canada soil and climatic conditions are almost ideal for the growth of "strong" wheats-a rich black soil and a "steppe" climate. Two general types of wheat prevail throughout this district-Fife and Velvet Blue Stem. In both types the heads are beardless, and the grains are medium or small, hard and red.

The average annual wheat production of this region is about 30 per cent. of the entire production of the United States. Much attention has been paid to wheat-breeding in this section, and the needs of the wheat-growers are less than in other districts. In the northern portion earliness of maturity is needed to enable the wheats to escape the early autumn frosts, and cold-resistant wheats are needed to stand the early spring frosts. In this connection it is interesting to quote from Bulletin, No. 52, of the North Dakota Experimental Station: "The exact degree of cold which will injure wheat depends to some extent on the stage of growth, the wheat plant has reached, and possibly upon some minor points. In the spring season of growth the order of tenderness of the cereals seems to be wheat, oats, and barley. The temperature which registers $26^{\circ} \mathrm{F}$. has been taken as representing what is commonly known as ' killing frost.' The shortest time, which has elapsed between 'killing spring and fall frosts,' is 121 days, the longest time 155 days, and the average length of time 136 days. The latest spring date was June 9, and the earliest fall date was September 9. The 
earliest spring and latest fall dates were April 15 and October 9."

As regards the length of time from sowing to harvesting, the Minnesota Agricultural Experimental Station gives the following for new breeds of "strong" wheats :

Minnesota No. 188. Bearded spring wheat-105 days (average of 14 years).

Minnesota No. 169. A blue stem wheat-109 days (average of 14 years).

Minnesota No. 163. A Fife wheat-108 days (average of 14 years).

The average yield could be made very much larger if more attention were paid to soil culture and seed selection. In Iowa, Nebraska, and parts of Wisconsin and Minnesota hard winter varieties might be grown with advantage.

The wheats are sown in late March and April, and harvested in late July and in August.

The hard winter wheat district includes Kansas, a large part of Missouri, portions of Iowa and Nebraska, and the larger part of Oklahoma. The grain of the wheats is medium or small, hard and red, and of the finest quality. Thirty-five years ago the softer wheats were chiefly grown over most of the region. Now, however, the hard, red-grained varieties are principally used, and only in Iowa and Nebraska is spring wheat-growing carried on to any great extent, and authorities are agreed that winter varieties are more suited to these two states. There is great need in all the states of hardier new varieties, and in those parts which suffer from drought, Durum wheats could be advantageously used. The chief varieties of wheat grown are: Turkey Red, Fulcaster, May, Zimmerman, and Fultz. 
It is easy to trace the potent influence of climate on the yield and quality of these wheats. The climate in winter approaches somewhat that of the "steppe," especially in the northern part, but nevertheless it is not severe enough to prevent fall wheat from being sown. The hard winters, high summer temperatures, and comparative abundance of sunshine in summer, all contribute to the excellent quality of the grain.

The winter wheats of this region are sown in September and early October, and harvested in June and July ; the spring wheats are sown in March, and reaped in July.

The Durum wheat district is small in area ; it includes a large part of North Central Texas, the south-western portion of Oklahoma, a small portion of the south-west corner of Kansas, and a part of Colorado. The soil is generally black and rich in humus, and produces wheats with a large gluten content, which quality is further increased in the western portion by the dry, hot, summer weather. The rainfall varies from 10 to 30 inches, and some parts suffer from drought, hence the increasing tendency to the growing of hard-grained, drought-resistant Durum wheats. Macaroni wheats are best adapted for spring sowing, but where the winters are mild, as they are south of the 35th parallel, they may be grown as winter varieties. It is well to emphasize the fact that it is not so much the rainfall that makes the wheat-grains of humid areas inferior in quality, but the combination of the factors-great rainfall, high humidity of the air, and lack of sunshine. Edmond Gain, in his work, "Influence de l'Humidité sur la Végétation," states that "ripening is promoted in a dry air and a humid soil, but is retarded 
in a humid air and dry soil." In the case of Durum wheats humidity is so injurious that semi-arid conditions are absolutely necessary for the best results in growing them. The conditions in this region with respect to humidity are very favourable; the average mean relative humidity varies from 55 to 65 per cent., and for the summer months is less.

Durum wheat-grains are very large and long, and are yellowish-white in colour, becoming darker the blacker the soil on which they are grown. Beside the Macaroni wheats the red-grained winter wheats are adapted to a large part of this region. "Dry-farming" operations may develop parts of this region more fully, especially in combination with irrigation farming.

The chief varieties of wheat at present grown are Mediterranean, Fulcaster, Nicaragua, Kubanka, and Turkey Red. They are sown in Texas and Oklahoma in September and October, and harvested in May and June.

Before considering the irrigated wheat and "dryfarming " region, consideration should be given to what are the arid regions. It is the custom to consider a region to be semi-arid when the rainfall is between 10 and 20 inches, and arid when less than 10 inches ; but previous considerations of soil and climate will convince the reader that these limits are arbitrary. The broad distinction between arid, semi-arid, and humid regions lies in the ability of such regions to produce crops annually with or without the artificial application of water. A convenient and easily marked line for the eastern boundary of the arid region of the United States is one closely following the 103rd meridian. On the north it bends away from 


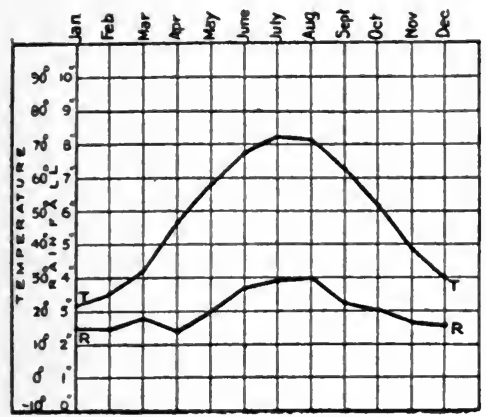

AlbaNy, N.Y.: Soft wheat.

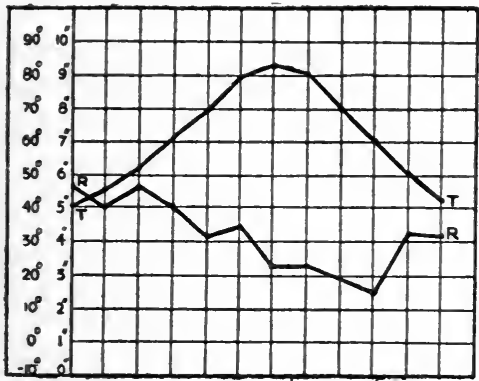

Memphis, Tenv. : Southern wheat - soft or semi-hard.

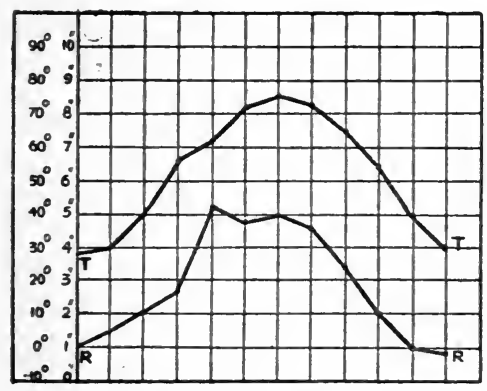

ToPEKA, KAN.: Hard winter wheat.

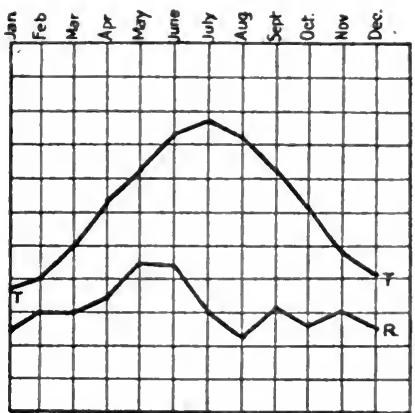

SPRINGFIELd, Ill. : Semi-hard winter wheat.

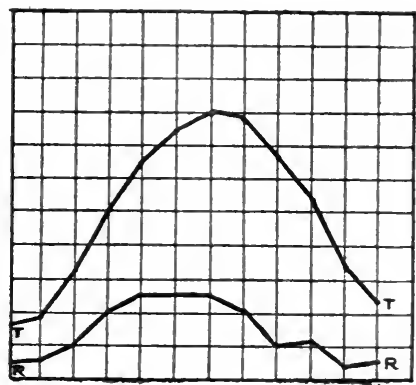

BIsMarck, N. DAk. : Strong, hard spring wheat.

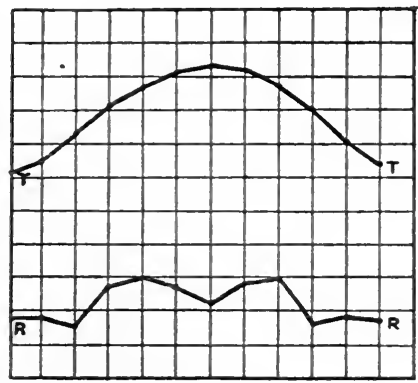

San Antonio, Tex. : Durum wheat.

Fig. 7.-Rainfall and Temperature Curves, United States. 
the meridian towards the west, and on the south tends eastwards north of the Rio Grande. On the west the arid region extends to the Pacific coast in extreme Southern California, but from Monterey north there is a belt of semi-arid and humid country bordering the Pacific Ocean. The arid region is a changeable quantity. Between the arid and the humid regions is a broad intermediate belt, known as the "semi-arid " or "sub-humid" region. It has no clear boundary, but shifts from season to season, backward and forward over a vast range of country, extending from the 97th to the 104th degree of west longitude.

In these arid tracts a combination of "dry-farming" and irrigation farming, or "dry-farming" or irrigation alone, may lead to their fuller development. Under "dryfarming" the nitrogen content of the wheat-grains is large, and the grains are flinty and transparent. Under irrigation a very light-coloured, opaque kernel is produced, that is very starchy and soft. The yield under irrigation is, of course, always greater than that under "dry-farming," but the quality of the grain is poorer. "Dryfarming," to-day, is the exception rather than the rule; the regions at present exploited by "dry-farming" operations are the Great Basin, the Columbia River Valley, the Interior Valley of California, and portions of the Great Plains. With the introduction of new varieties of drought-resisting wheats, and improved methods of farming, the area under "dry-farming" will undoubtedly increase, but the great bulk of the wheat crop in these arid regions, it would seem, must depend largely on an adequate supply of water from irrigated ditches. 
"Dry-farming" in the Great Basin is practically limited to the state of Utah, where it has been carried on to some extent since 1875 , and its practice has been rapidly increasing since 1900 . The work was begun by private individuals, but the state of Utah is now supporting six experimental farms for testing varieties, and working out scientifically the best rotation and tillage methods. Farming is successfully carried on with an annual rainfall of 15 inches, or slightly less. Clean summer fallowing and alternate year cropping, together with thorough tillage, are the bases of successful "dryfarming " in the Great Basin. Under the best methods of tillage the land appears to remain highly productive, even where no other crop than wheat is grown. There are several varieties of wheat in common use both on the dry lands and under irrigation. With a few exceptions, the wheats grown are fall-sown varieties of bread wheats, and the more popular varieties are known locally under the names of Lofthouse, Kofoid, and Gold Coin. Durum wheats, and some of the spring wheats, such as Fife and Blue Stem, together with the hard, red-grained wheats of Kansas and Nebraska, are now under experiment.

The irrigated wheat region includes Wyoming, a part of Montana, Southern Idaho, Utah, Nevada, Arizona, New Mexico, and the greater part of Colorado. The striking characteristics of this region are : (1) The extreme aridity, the rainfall varying from 0 to 15 inches; (2) the dryness of the air, the relative humidity, varying from 45 to 60 per cent.; (3) the very low humus content of the soil ; and (4) the superabundance of alkali usually present. 
Wheat does best in a soil that is alkaline rather than acid in reaction, but an excess of alkali becomes very injurious. The greatest need of this district is an increase in the gluten content of the grain. The first requisites for wheat improvement are the dispersion of the excessive accumulations of alkali, and the application of fertilizers to increase the humus content of the soil, together with the growing of leguminous crops in alternation with wheat. The introduction of hard-grained nitrogenous varieties of wheat is at first an advantage, but deterioration soon takes place. The hardest Red Fife from North Dakota, and Turkey Red from Kansas, become rapidly more starchy and of a lighter colour on being grown in Utah or New Mexico; the only remedy is thus the improvement of the soil. In the more elevated portions of this region early maturing varieties, or frost-resistant varieties, should be grown on account of early autumn frosts. The chief varieties of wheat grown under irrigation are : Kubanka, Turkey Red, Velvet Don, Black Don, Polish, Kharkof, Siberian, Sonora, Little Club, and Defiance. They are sown in September, October, and April, and harvested in June, July, and August.

The white wheat district covers in a general way the Pacific Coast region, including California, Oregon, Washington, and Northern Idaho. The most noteworthy feature of the climate is the variation in rainfall. While the difference in temperature between the northern and southern limits of the Pacific Coast is very much less pronounced than it is on the Atlantic seaboard, the differences in methods of conducting farming operations, made necessary by the extreme variation in rainfall, are far 
greater than those existing along the entire length of the Atlantic Coast.

On the Atlantic Coast from Nova Scotia to Southern Florida a humid climate, with abundant warm summer rains, prevails during the crop-growing season, and is seldom departed from; the farmer is thus governed in his operations almost exclusively by climatic conditions. This is also the case in the northern section of the Pacific Coast region. In Oregon, Washington, and the more northern portion of California, extending southward to about Mount Shasta, sufficient rainfalls may be expected throughout the entire crop-growing season.

Mount Shasta is practically the northern limit of the region of dry summers, which embraces by far the larger portion of the state of California, and practically all of its wheat area. In Washington, the average annual rainfall varies from 100 inches on the shore line to less than 10 inches in the Yakima Valley on the eastern side of the Cascades. Similar conditions exist in Oregon and Idaho. The greatest variation in rainfall exists in the great interior valley of California, from 36.6 inches at Redding, its extreme northern end to about 4 inches near Bakersfield at the southern end of the San Joaquim Valley. Since nearly the whole of the rainfall occurs within a period of seven months (November to May), and by far the greater part within the three winter months, during which the wheat-crop makes its principal growth, it becomes perfectly feasible to mature grain on a comparatively light rainfall before the beginning of the rainless summer.

The mean annual relative humidity of the air varies 


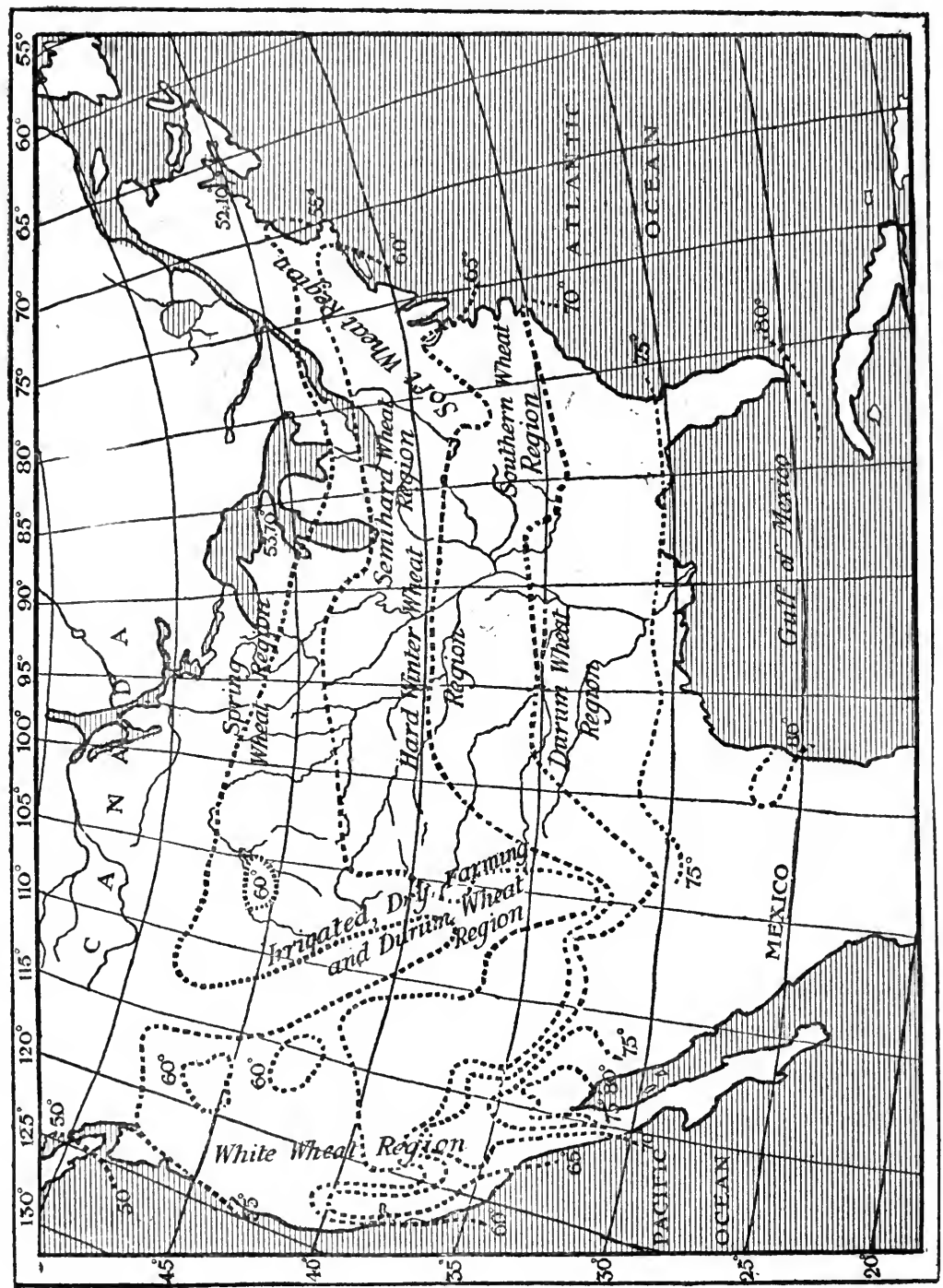

風 
from 45 to 85 per cent., being greatest over the coastal regions, and least over the arid tracts.

All the wheats of this district are characteristically white-grained, soft, and starchy. The probable factor, most potent in producing such a grain, is the lack of

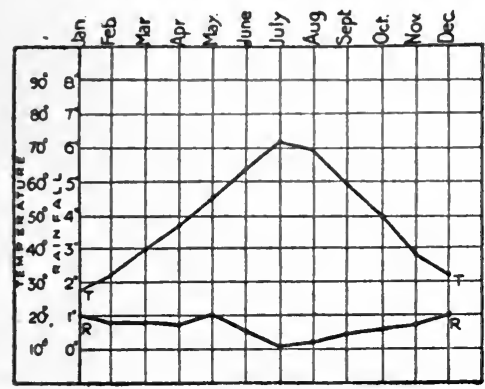

WinnemucA, NeV.: Irrigated wheat and "dry-farming."

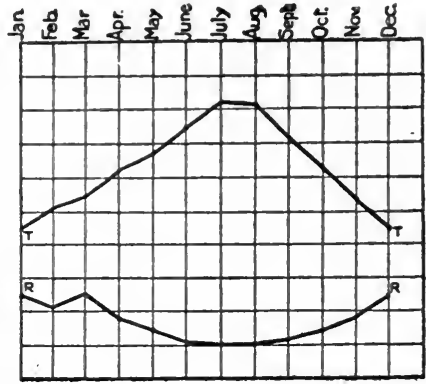

Fresso, Cal.: Soft dry white wheat district; irrigation and "dry-farming."

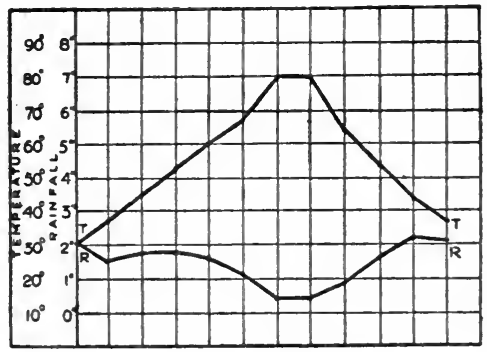

WALla-Walla, Wash. : Soft white wheat.

Fig. 10.-Rainfall and Temperature Curves.

humus in the soil, though doubtless the rainfall lends aid. Hard varieties, such as Turkey Red, deteriorate in a few years when grown in this region.

Club wheats are characteristic varieties over most of the district. Sonora, Defiance, the Australian of Cali- 
fornia, Red Chaff of Oregon, and Palouse Blue Stem of Washington are not, however, Club wheats. A very valuable characteristic of the Club wheats is their ability to hold the grain in the chaff ; and this is of great importance, for often, though the grain ripens in July, it is left standing till September before harvesting.

The Palouse country of South-Eastern Washington, and the adjacent portions of Idaho and Oregon, possess peculiarities of soil and climate radically different from those of the Pacific Coast region proper. The two distinguishing features are the dryness of the climate and the very finely-divided condition of the soil. The particles are so very fine that when dry the soil is practically mere dust. The capacity of this soil to absorb and retain moisture is remarkable. It is fairly generally believed that a rainfall of 12 inches in this district is sufficient for the production of a crop of wheat, while in the States of the Plains 18 inches is considered to be rather low for successful wheat-growing. The wheats grown are like those of the coast regions, but of slightly better quality, owing to the drier climate. The most serious obstacle to successful wheat culture in the Palouse country is the annual recurring drought, which occurs about two weeks before harvest time; early maturing varieties are thus needed.

Both fall and spring seeding are practised, and often with the same varieties. The times of seeding are from September to late April, and of harvesting from late May to early September. 


\section{Mexico and Central America.}

Mexico and the Republics of Central America do not loom prominently among the wheat regions of America; their production is not enough for their own needs, though climatic and soil conditions are suitable in many parts. Mexico is by far the greatest producer of wheat ; in Nicaragua, Panama, Costa Rica, Cuba, Guatemala, Haiti, and the Dominican Republic not sufficient wheat is grown to form an important industry ; in Salvador wheat is grown in all her provinces, but not enough is produced for her own needs; and, in Honduras, wheat is not grown on a scale which the demands of the country seem to justify.

Though a great part of these regions lies in the Torrid Zone, yet on account of their topography every variety of climate is found, the difference in temperature corresponding roughly to the difference in altitude. The climate is usually divided into three kinds. The hot lands are considered as extending from the coast to an altitude of $1,000$ metres ( 1 metre $=39 \cdot 37$ inches $)$; the temperate from 1,000 to 1,400 metres; and the cold from 1,400 metres upwards. In Mexico, the thermometer registers an average annual temperature in the hot regions of $77^{\circ}$ to $82^{\circ} \mathrm{F}$., in the temperate from $62^{\circ}$ to $77^{\circ} \mathrm{F}$., and in the cold from $55^{\circ}$ to $62^{\circ} \mathrm{F}$.

The greatest part of the wheat harvested in Mexico is produced on the Central Tableland at an elevation of from 2,000 to 3,000 metres above sea-level, and between the 16th and 24th parallels of north latitude. The chief wheat-producing states are Michoacan, Sonora, Guanajuato, Puebla, Coahuila, Mexico, Durango, Jalisco, 
and Querétaro. In the greater part of the region where it is grown wheat has to be watered, because during the winter season very little rain falls, and at times none at all. The rainy season sets in at the end of May, or the beginning of June, and ends in September or the beginning of October. Wheat is generally sown in October and November, and harvested in April and May.

Mexican territory, owing to its topography, presents many difficulties with regard to irrigation. The land rises abruptly from the coast to a habitable altitude of over 3,000 metres, thus creating a serious and almost insurmountable obstacle both to the retention and gradual absorption of the rain waters, which are precipitated over the rough surface of the land, and, passing with great rapidity over the fields and river-beds in their course to the sea, leave behind a deplorable and ruinous drought, and in places an almost perpetual aridity. An extended rainy season is of especial necessity to the profitable cultivation of the soil in all the Central Tableland and the cold regions. Where the rainfall is scanty, as in the extensive sections of the northern frontier, and in the states of San Luis Potosi and Zacatecas, or where there is an alteration in the period of the rainfall, the crops are lost.

The soil of much of the Central Tableland is well adapted to the growth of wheat, and in some parts admirably so ; the soil of Sinaloa is even richer than the soil of California, and fertilizers are as yet unknown there.

There are sown in Mexico the red semi-hard wheat, which produces a very white flour, and the white starchy wheat, which produces less flour, but grows more easily 
and rapidly than the red. Climatic conditions, the nature of the soil, and the methods of cultivation are the deciding factors in the yield of the wheats, and the moderate quality of the grains. The production of wheat in Mexico could be greatly increased by better farming methods, by the more general adoption of irrigation, by "dry-farming" methods in the arid parts, by the introduction of drought-resistant Durum wheats, and by the practice of careful seed selection.

As regards the other republics of Central America wheat production could be considerably increased; the plateaux are in many cases well adapted to the growth of this cereal. In Honduras, in the provinces of Copán and Intibuca, the climate and soil are both favourable, and most of the wheat is grown there. It is said that the soil of Guatemala is exceedingly favourable to wheatgrowing, especially on the plateaux of the Cordillera, where the strongest argillaceous soil is encountered.

\section{Countries East of the Andes.}

Argentina and Uruguay are by far the most important wheat-growing countries east of the Andes; in all the remaining republics wheat production is of little importance. Argentina is a very successful competitor in the world's wheat markets, and her capacity to produce wheat may almost be said to have taken the world by surprise. It is comparatively but a short time ago, that little or no consideration was given to the great advantages which Argentina could easily develop, in her large level plains, variety of climate, absence of forests, and other obstruc- 
tions, and proximity to the seaboard and navigable rivers.

A general idea prevails that Argentina consists mainly of a boundless level plain, for which the early settlers retained the old Quichua term "pampa," but a closer study of the actual build leads to some modification. Doubtless a great part of Argentina was in past times flooded by the Pampean Sea, and consequently presents a nearly horizontal surface, with a slight, and in some places, a scarcely perceptible incline towards the Atlantic. The pampas are, however, greatly diversified by Andean highlands in the north-west between the Pilcomayo and Bermejo basins, and farther south in the province of Mendoza, and the territories of Rio Negro, Chubut, and Santa Cruz.

Wheat is mainly produced on the level pampas. These vast plains are recognized as entirely alluvial deposits, and supporting this theory, the fact is adduced that no stones of any appreciable size can be found within many miles of Buenos Aires. The hard clay substratum, called "tosca," is the nearest approach to rock. There are various textures of "tosca." Some of it is called soft, but this is only so in wet weather. "Tosca" is found underneath the sands outside Buenos Aires, and under the whole plain for hundreds of miles; the black soil, or other fertile upper stratum, is of varying thickness, sometimes ample for deep ploughing, sometimes too shallow for any cultivation. Over the whole of the plain meander channels, which in the wet season are full, but are merely dry "arroyos" during most of the year.

The Argentine Department of Agriculture furnishes 
the following description of the present and future wheat soils: "Three-fourths of the arable land-263,195,000 acres - is formed of vast plains crossed by low hills, of alluvial deposits of recent volcanic and granitic origin, composed of fine, light, often loose and seldom stiff siliceous soils, free from stones, generally permeable, as are also their subsoils, and of a depth varying from 10 to 50 inches, which nearly always contain a considerable portion of vegetable earth. They are, therefore, in the highest degree excellent for agriculture, and for growing the best species of forage plants.

"The land in the east, north, centre, and west, and part of the south of the province of Buenos Aires, and the southern part of Cordoba and Santa Fé has a light pumiceous soil, often forming downs, which allow an easy drainage, and may be considered the best in the world. In the south-eastern and southern parts of the province of Buenos Aires the soil becomes lighter and more sandy. Toward the west stretch the extensive plains of the Pampa, formed of a light, sandy, humiferous soil, which becomes more fertile in Mendoza and San Juan, where it is very deep, often mixed with pebbles, and rests on a subsoil formed exclusively of shingle, which favours the natural drainage, and thus facilitates drainage. The province of San Luis is similarly formed, but in general the soil is not so deep, and is less humiferous than in the Pampa. The soil of the south of Santa Fé, and of the centre of Cordoba, is sandy, somewhat dry, and wooded. In Entre Rios the soil is sandy, somewhat clayey, and often light and rich.

"In the territories of Rio Negro, Chubut, Santa Cruz, 
and Tierra del Fuego, the soil has the same physical features as in the Pampa, and is generally light and sandy, with the exception of the bottom of the valleys, where clayey, humiferous soil of great richness is always found."

Argentina possesses climatic advantages of no mean order. The farmer is able to work his land at almost any time of the year he chooses, and it costs him little to care for his cattle. It is not necessary for him to spend much time or money in preparing feed to carry his cattle through the winter, as the farmers of North America are compelled to do. Wheat harvest occurring in December, makes it possible to ship wheat at the end of January, and this is a great advantage, since the shipments are sandwiched between those of North America and those of Southern Asia.

Climatic disadvantages must also be recorded. These are wet summers and autumns followed by warm, open winters, which encourage the growth of weeds, and wheat is liable to be choked; the cold fogs and late frosts that occasionally occur in November or December, followed by hot sun and winds, which work fearful havoc among the wheat; the hot winds that sweep across the plains from the north in November and December, accompanied by clear skies, and a burning sun, leading to the shrivelling of the wheat plant; the drought, which occurs in the south; and hailstones, which work much damage over certain portions of the Republic.

A certain amount of injury to vegetation is done by locusts every summer. The species of crop which suffer are determined by the date of their appearance. Wheat is practically safe as soon as the ripening process begins. 
The methods adopted for the destruction of the locusts are well organized, and if equally well carried out, can scarcely fail to deal with any ordinary visitation. Every few years, however, swarms reach gigantic proportions, and it remains to be seen whether the Argentine farmers will in the future be able to cope with an abnormal plague of locusts.

The Argentine seasons are :

Summer : December, January, and February.

Autumn : March, April, and May.

Winter: June, July, and August.

Spring : September, October, and November.

The Republic may be divided into four zones of varying temperature. The first includes the low plains of the north, situated between the parallels of 22 degrees and $31 \frac{1}{2}$ degrees south latitude, possessing a subtropical climate, and having a mean annual temperature varying from $67^{\circ}$ to $75^{\circ} \mathrm{F}$.; the second comprises the section of the plain from $31 \frac{1}{2}$ degrees to 42 degrees south latitude, possessing a temperate climate, and having a mean annual temperature varying from $56^{\circ}$ to $66^{\circ} \mathrm{F}$.; while the third or southern part of the plain, from 42 to 55 degrees south latitude, possesses a subtemperate climate, and a mean annual temperature varying from $41^{\circ}$ to $56^{\circ} \mathrm{F}$. The fourth or mountain zone, extending the length of the country, affords a variable climate.

From October to March may be called the wet season of Argentina north of 38 degrees south latitude, and from April to September the dry season. In Buenos Aires 56 per cent. of the annual rainfall occurs in the wet season ; 
in Corrientes, 65 per cent. ; in Cordoba, 86 per cent. ; and in Salta, 96 per cent. South of 38 degrees south latitude the distribution of rainfall is very even throughout the year. The rainfall varies in Argentina from extreme arid conditions to as much as 80 inches per annum. The annual average rainfall in the chief wheat districts is as follows: Province of Santa Fé, 32 to 40 inches; province of Buenos Aires, 25 to 32 inches; province of Entre Rios, 38 to 48 inches ; province of Cordoba, 24 to 32 inches; territory of Rio Negro, 9 to 16 inches; territory of Chubut, 9 to 16 inches; and territory of Pampa, 16 to 24 inches.

An important point in the growth of the Argentine wheat area has been the widening of the territory yielding supplies, with the consequent diminution of the risks of failure from drought, frost, and hail. Thus in 1895 the growth of wheat was largely concentrated in the Province of Santa Fé and part of Cordoba; these two provinces representing two-thirds of the total area; in the province of Buenos Aires, 18 per cent. ; in Entre Rios, 14 per cent. ; and elsewhere, about 1 per cent. In 1908 it was Buenos Aires, 40 per cent.; Cordoba, 25 per cent.; Santa Fé, 23 per cent. ; Entre Rios and Pampa, each 5 per cent.; and elsewhere, 2 per cent. Up to 1900 the trend of wheat-growing was towards the north, but the wheatgrowers soon found the limit, and the tendency now is to grow wheat to the south and south-west of what was formerly deemed to be the real wheat country.

Seeding begins late in the autumn in Northern Argentina, usually in May, and continues until the middle of August in the south. June and July are really the 
seeding months. Harvesting begins about the middle of November, and lasts till the middle of January, 80 per cent. of the crop being harvested in December.

Argentine wheat regions may be divided roughly into three main districts :

1. The hard Durum wheat district of the North, including chiefly the northern parts of the provinces of Entre Rios and Santa Fé.

2. The semi-soft wheat district of the Centre, including chiefly the provinces of Santa Fé, Buenos Aires, Entre Rios, and Cordoba.

3. The semi-hard wheat district, including chiefly the territories of Rio Negro, Pampa, and Chubut.

The Macaroni wheat district is small in extent. Three varieties of wheat are grown. The principal one is Candeal, which possesses a very hard rice-like grain, but is exceeded in yield by Anchualo. Tongarro, the third variety, is not much grown. The high temperatures, comparative dryness of the air, the breed of the wheats, and the sandy nature of the soil, determine the nature of the grain. Argentina only grows enough Macaroni wheat to supply her semolina mills.

The semi-soft wheat district is by far the most important; it supplies the greater part of the wheat-export. The common bread wheats, Barletta, Russian, Hungarian, French, Saldome, Tusela, Italian, and Piedmontese, are chiefly grown. Barletta, brought from Italy, resembles somewhat the Turkey Red of Kansas, but the grains are softer, and the quality not so good. It is the favourite variety throughout the country, and has shown its superior adaptability to various Argentine 
conditions through many years. It produces fat, darkcoloured, smooth, rich grains, and does not degenerate as some other kinds do. To the wheat farmer its value lies in its ability to stand a long time ripe without being shelled out by high winds. Farmers, who either rely on family labour, or use strippers, find Barletta a great advantage. Barletta best resists changes of climate, drought, and rust, and is not so likely to be damaged by extreme heat, or by cold, damp fogs, and late frosts. This is the only variety that is grown from one extreme of the wheat-growing area, as far as 31 degrees south latitude, to the other, as far as 45 degrees south latitudeover 800 miles. It is to be noted that it produces a much harder grain in the south, gives a better yield, and is of a distinct type from the grain of the same seed grown in the north. Barletta is preferred by buyers to all others, on account of its fairly high gluten content. Russian wheat is the next in popularity, and gives the best results in the South. It ripens in less time than Barletta, but shells out easily when ripe, so that it has to be harvested quickly. Its gluten content is high. No other varieties rank high in quality, nor in extent.

Climatic factors largely account for the comparative softness and fairly high quality of the wheats of this region. Breed is a dominant factor in the suitability of Barletta to all districts, though the effect of climate is seen in the better quality of Barletta grains grown in the south.

The semi-hard wheat district is small in extent at the present time. It possesses a climate corresponding somewhat to that of the hard winter wheat district of the United States. The air is fairly dry, the temperature 
Corrientes, Corr.: Durum wheat.

Rainfall : heavy, but temperature high.

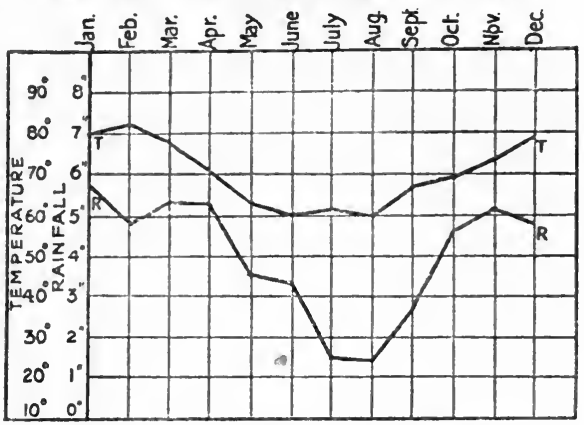

Patagones, Rio Negro: Semi-hard wheat.

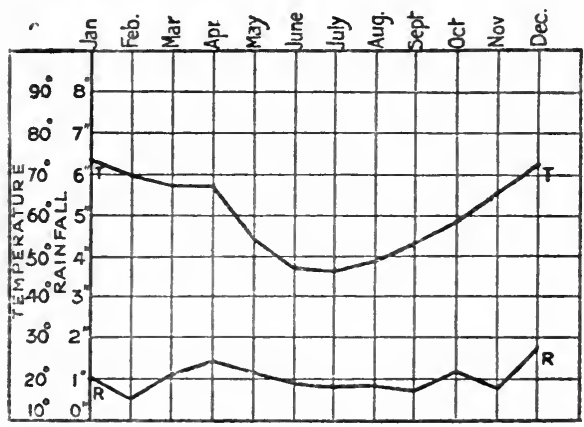

Buenos Aires, Buenos Aires: Semi-soft wheat.

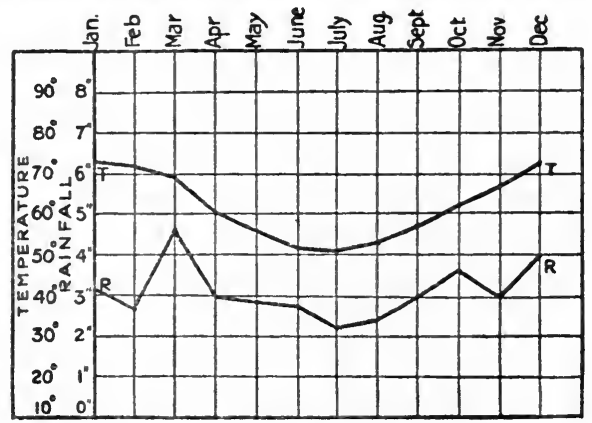

Fig. 11.-Rainfall and Temperature Curves, Argentina. 


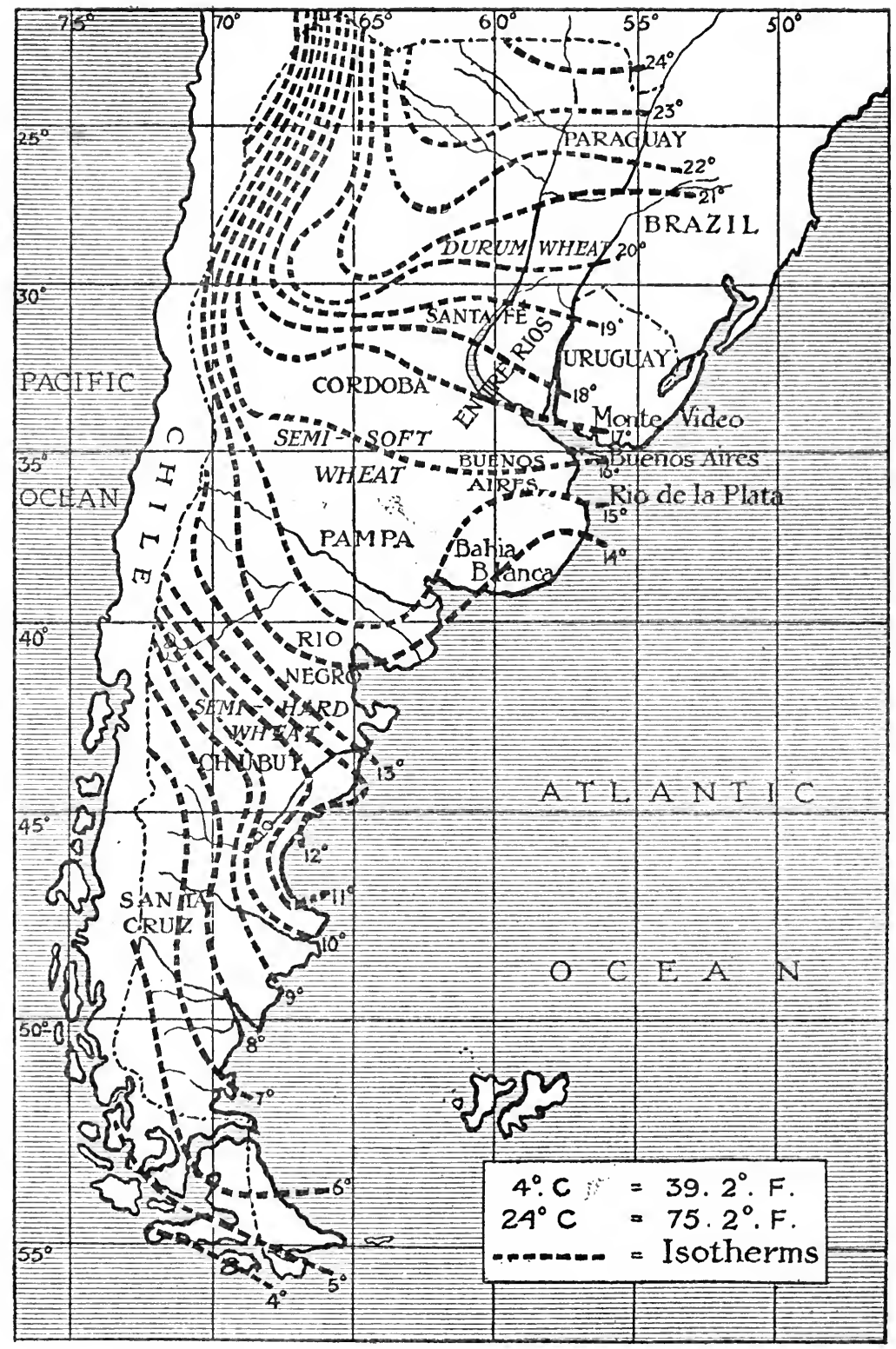

Fig. 12.-Argentina : Yearly Isotherms (Centigrade). Commercial wheat regions lie between the isothermals $11^{\circ} \mathrm{C}$. and $19^{\circ} \mathrm{C}$. $\left(52^{\circ} \mathrm{F}\right.$. and $66^{\circ} \mathrm{F}$.) 




Fig. 13.-Argentina: Annual Rainfali. 
moderate, and the rainfall just sufficient in some parts for crop production, while in others it is by no means adequate. Irrigation is carried on to some extent, and possibly "dry-farming" may obtain a footing in the future. The wheats grown are of the same varieties as those of the semi-soft wheat district, Barletta being the prime favourite.

Where wheat is grown it gives a higher yield and better quality than in the other regions. On the English market the semi-hard wheat has established its reputation. The coolness of the climate and the moderate rainfall are largely responsible for the high yield and superior quality. Chubut Barletta wheat took the gold medal at the Paris Exposition in 1889, and it is said that Chubut wheat sometimes weighs more than 66 pounds per bushel.

Though great advances have been made by Argentina within the last twenty-five years, yet her wheat output and its quality could be very materially improved by paying attention to better farming methods, irrigation, "dry-farming," the application of fertilizers to depleted soils, and the introduction of Asiatic wheats-droughtresistant and of high gluten content.

Uruguay is of more importance with regard to her export rather than her output. The climate and soil of her wheat fields are somewhat similar to those of the Provinces of Entre Rios and Buenos Aires. The chief crop of Uruguay is wheat, the annual production amounting to about 7,500,000 bushels, of which about 5,000,000 bushels are exported. In Paraguay wheat is grown with success, but the growth of maize is found to be more profitable. 
Brazil, from its past history, is worthy of mention. The production of wheat is still very small, notwithstanding the fact that many of the States south of the tropics, and the high lands of some of the Northern States, are suitable for its production. The State of Rio Grande do Sul cultivated wheat so extensively in past years that it furnished wheat to all the Northern States of Brazil. The most favourable climatic conditions for the cultivation of wheat exist on the entire plateau of the Montiquira Range, in the Orgăos Range, in the Cantagallo and Nova Friburgo Plateaux, and even in the States of Serigpe, Espirito Santo, Bahia, Pernambuco, and Céara. Many experiments have been conducted in recent years, and varieties such as Barletta, Rieti, and Fucense have given good results; but doubtless Brazil will continue to rely upon Argentina for her wheat.

Wheat in Venezuela is at present cultivated in Trujillo, Mérida, and Táchira. The high tablelands and valleys in the mountainous districts of Western Venezuela are best suited to the cultivation of wheat, and fine crops are raised there, but the total production of wheat is very small.

\section{Countries West of the Andes.}

Chile is the chief wheat-growing region west of the Andes. The wheat area is calculated by Chilian authoriities at about 2,000,000 acres, and the production at about $18,000,000$ bushels, of which $2,500,000$ bushels to $5,000,000$ bushels arc vearly exported.

Wheat $s$ cultivated in Chile both on semi-arid and irrigated land. The former occupies a larger area, be- 
cause there it is usual to leave the land fallow from one year to another. For the most part it is found to be the land round the Coast range. The irrigated land is principally situated in the Central Valley, which extends from the Coast range to the foot of the Andes, and stretches without interruption between 33 and 42 degrees south latitude. The arable lands of Chile are divided into the regions of the north, of the centre, and of the south.

The northern region includes the provinces of Coquimbo and Aconcagua ; the central region comprises the territory between Santiago and Concepcion; and the southern region includes all the lands south of the Bio-Bio River. Each of these regions is again naturally divided into three sections - the coast country, the central valley, and the western slope of the Andes.

Arable lands, whose soil has been formed by the decomposition of plutonic rocks, cover a large part of Chile. In general, they are found on ridges, hills, and high plains, and constitute the semi-arid lands called "secano." In the south these lands are generally poor, and require fertilizers. The arable lands, the soil of which has been made from underlying sedimentary formations, are full of gravel and stones, and often occupy large areas. In the longitudinal and transverse valleys the soil is mixed with sand and clay. Where water used for irrigation has annually deposited its load of silt, a very rich soil has resulted, as in part of the Plain of Santiago, where the Maipo Canal has deposited sediments. Soils, which have been formed from underlying sandy deposits, are found chiefly in the Longitudinal Valley 
between the Rivers Itata and Bio-Bio. Calcareous soil is scarce, and, in the north, where it is found, the lack of water dooms it to almost complete barrenness. The arable lands made from rock of eruptive or volcanic origin are found in the Longitudinal Valley. They are unirrigated, but very fertile.

In the Central Valley, the uplifting of the Andes has contributed largely to the formation of an arable soil. The subsoil in the valleys of Santiago and Rancagua is composed of a deposit of rounded stones and gravels, which reach to a great depth. It is covered with a layer of sand and pebbles, upon which in turn rests a bed of vegetable mould of varying thickness, sometimes reaching a depth of several yards, as at Santiago, Rancagua, and other places.

The climate of Chile varies greatly, not only on account of its position, but also through the influence of the winds from the Cordilleras, and the currents of the South Pacific. The cold ocean currents, which leave the Antarctic regions, wash the coasts of Chile, and the peculiar shape of the country, which is a long, narrow strip, hemmed in between the snowy Andes and the sea, causes the temperature to be about $6^{\circ} \mathrm{F}$. lower than that in the same latitudes in other parts of America. In the North the temperature fluctuates little during the year, showing an average of $55^{\circ} \mathrm{F}$. in winter, and $70^{\circ} \mathrm{F}$. in summer. In Central Chile the average winter temperature is $52^{\circ} \mathrm{F}$., and the summer temperature $68^{\circ} \mathrm{F}$. The climate of the Central Valley and of the coast between 32 and 36 degrees south latitude is one of the most pleasant in the world, the thermometer seldom rising 
above $77^{\circ} \mathrm{F}$., or falling below $32^{\circ} \mathrm{F}$. Many parts of Chile suffer from lack of rain; in the north as far as 30 degrees south latitude rain is the exception, although dense clouds are of frequent occurrence. Central Chile possesses a "Mediterranean climate." From 36 degrees south latitude southwards, rain falls on most days, but especially in winter; the largest rainfall occurs about 41 degrees south latitude. The following table gives the average annual rainfall for a number of years :

\begin{tabular}{|c|c|c|c|c|}
\hline & & & & Inch \\
\hline Serena & . & - & - & $6 \cdot 75$ \\
\hline Santiago & .. & .. & .. & $16 \cdot 00$ \\
\hline Talca .. & .. & . & -. & $22 \cdot 00$ \\
\hline Concepcion & .. & .. & .. & $53 \cdot 00$ \\
\hline Valdivia & .. & .. & .. & .. $112 \cdot 00$ \\
\hline Puerto Mont & & .. & .. & .. $104 \cdot 00$ \\
\hline
\end{tabular}

Chile divides naturally into three wheat districts, corresponding to its climate, soil, and latitude-the northern, the central, and the southern wheat districts.

In the northern zone the varieties of wheat grown are of the red, hard variety. The character of the grain is determined by the small rainfall, the high summer temperatures, the great differences between day and night temperatures, the dryness of the air, the breed of the wheats, and the nature of the soil.

The varieties of wheat grown in the central district are of a much more starchy nature, and are of the Oregon white type, American, and Australian. The starchy nature of the grain is due to the lack of sufficient humus in the soil, and to irrigation waters.

In the southern zone the white small wheats, and those varieties, as Linaza and Mocho, which resist the rain, are grown. Breed is a factor in the moisture-resisting 
qualities of these wheats, and climatic and soil conditions, especially rainfall and the high humidity of the air, are responsible for the starchy and soft nature of the grain.

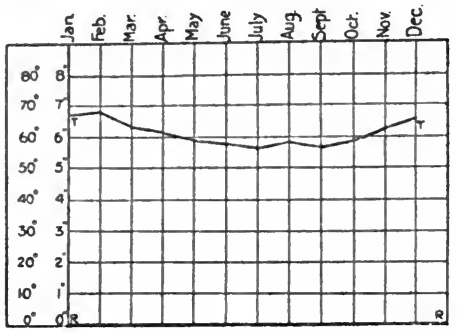

Caldera, Atacama : Hard red wheats, where irrigation is practised.

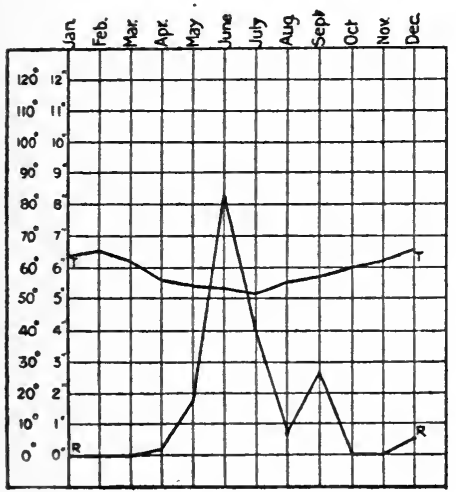

Punta Anjeles, Valparaiso : Starchy wheats.

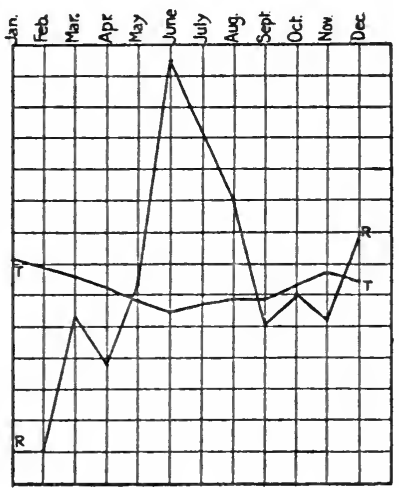

Axcud, Chile: White small wheats-rain resisting.

Fig. 14.-Rainfall, and Temperature Curves, Chile.

Wheat is most successfully cultivated in the provinces of Coquimbo and Concepcion. Good land in the provinces of Aconcagua, Valparaiso, Santiago, O'Higgins, Curico, and Talca yjeld from 15 to 20 bushels per acre. In the vast fertile plains of ancient Araucania, now the provinces 
of Biobo, Malleco, and Cautin, wheat grows well. In the southern zone the harvests of wheat are uncertain, because the climate is in parts too cold, and the rains sometimes prevent the crop from ripening.

Sowing takes place in May, June, and July, the months in which the rain chiefly comes, and harvesting begins at the end of December in the north, and lasts until the beginning of March in the south.

Chilian wheat-growers need to pay attention to : Better farming methods, for at present the methods are often primitive; irrigation, though much has been done; the quality of the wheats, which might be improved by seed selection and wheat-breeding; the application of fertilizers to the land; and it would seem that in the arid parts "dry-farming" might increase the wheat area.

Of the other Republics little mention need be made. The regions of Colombia most suitable for the cultivation of wheat are the plateaux of Cundinamarca and Boyacá, in the centre of the Republic; but the yield of wheat is insufficient for local demands. In Ecuador wheat is raised on the plateaux in sufficient quantities for home consumption, and in some years there is a small export to Peru. Peru does not grow enough wheat to supply her own local demand, and the small amount grown is cultivated on the tablelands of the interior. In Bolivia wheat is grown in very small quantities in the immediate vicinity of Lake Titicaca. 


\section{CHAPTER V}

\section{CULTIVATION AND HARVESTING OF WHEAT}

THe development of wheat culture from its early primitive form to its modern intense and scientific form has been very gradual, and we naturally find that wheat cultivation has only reached its highest development in the oldest civilized countries. Farming conditions in America are vastly different from those existing in Europe, and it is necessary for the intensive cultivator of Europe to banish from his mind all preconceived ideas of what wheat cultivation should be. Many factors must necessarily be considered before a true idea can be gained of wheat farming in America. Attention must be concentrated on the systems of land-tenure, the vast size of many of the farms, the quality and quantity of the labour employed, the amount of capital at the disposal of the farmer, the fertility of the soil and its comparative cheapness, and the use of modern inventions in machinery.

In Canada and the United States wheat is cultivated better than in South America, though little intensive cultivation is carried on, except in the east, and even in the east to but a small extent. Intensive farming of wheat commenced in the eastern United States some years ago, to some degree at least-that is, better cultiva- 
tion is given to the soil, a smaller acreage is grown, and manures are used to a considerable extent. The probability is that the United States is reaching that stage in agriculture when intensive cultivation must generally be adopted. Within the last thirty years wheat cultivation has greatly improved in these two countries, and this is largely due to the Departments of Agriculture, and to the Experimental Farms, which are to be found in many of the provinces of Canada, and in the States of the Union. It is safe to state that these institutions have been a very vital factor in the wheat industry of America. The Governments of Mexico, Argentina, and Chile, are now making efforts to improve wheat culture in their respective countries by the establishment of Departments of Agriculture, and the distribution of literature bearing on farming methods.

The systems of land-tenure on the grain-fields present some points of difference in North America as contrasted with South America. The tenant system is not very common in North America, whereas in Argentina this system is much in vogue. Arthur Young said, "The magic of property turns sand into gold," and there is much truth in this statement, for there is an incentive to good cultivation, since the cultivator, who owns his own land, is urged on by the hope of gain for himself. Lack of interest in the land is largely due to lack of title to the soil, and this accounts to some extent for the exhaustion of the land in parts of America by bad tillage and continuous cropping. Two plans of renting land for agriculture are followed in Argentina. Ninety-five per cent. of the small farmers begin under the "medianero," or share system; 
the owner has then some interest in the manner of cultivation, but poor results follow as regards tillage. As soon as possible the small farmer, usually an Italian, gets into the second class of "arrendatarios," or cash renters. $\mathrm{He}$ easily finds some landowner who will give him land, a mud hut or " rancho," horses, bullocks, implements, and seed, to farm on bis own account. The wheat is sold by the landowner at the end of the harvest, and, after taking out the cost of seed, bags, binding-twine, and threshing, the proceeds are divided, as a rule, evenly between the farmer and the landowner; hence the name "medianero." The Italian farmer is a great saver, and in one to three years he is able to rent land for cash, and furnish everything for himself. His land "hunger" is great, and he will cheerfully undertake to farm 400 to 500 acres with just the help of his family. The result is that he simply scratches the land, and leaves the rest to Providence. Probably three-fourths of the Argentine wheat crop is grown by people of the class who rely on family labour. The remaining one-fourth is raised on large farms, some of which are owned and managed by Englishmen and Americans, who are doing excellent work. Some native "estancieros" have lately begun to cultivate wheat. In many localities in Argentina, colonies of Welsh, Germans, Russians, Hungarians, or Scandinavians have been established, and these colonies are a more hopeful sign than the renting system under which the Italian labours, for the colonists become naturally attached to their new homes, when they acquire titles to the land, whereas the Italian's main endeavour is to save enough to enable him to get back to Italy. 
The following tables illustrate the systems of landtenure in America :

United States, 1899: Percentage of Wheat Acreage.

\begin{tabular}{|c|c|c|c|}
\hline Owners & .. & .. & \\
\hline ners & & .. & \\
\hline Owners and tenants & & .. & \\
\hline Managers & & & \\
\hline Cash tenants & $\cdots$ & & \\
\hline Share tenants & & .. & \\
\hline
\end{tabular}

Canada, 1901 : All Agricultural Land.

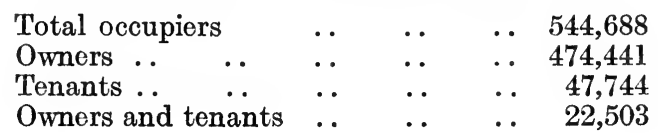

Argentina, 1908 : Percentage of Farms.

\begin{tabular}{|c|c|c|c|}
\hline & Owners. & Arrendatarios. & Medianeros \\
\hline Province of Buenos Aires.. & $26 \cdot 20$ & $61 \cdot 80$ & 12.00 \\
\hline Province of Santa Fé & $34 \cdot 26$ & 51.53 & $14 \cdot 21$ \\
\hline Province of Entre Rios .. & $42 \cdot 69$ & $41 \cdot 80$ & $15 \cdot 51$ \\
\hline
\end{tabular}

Free gifts of land in Canada by the Government have had much to do with the increased acreage under wheat, and mention must be made of the aids now given to wheat-farming by the Canadian Pacific Railway Company in providing cleared and stocked farms for immigrants at a rental of a certain proportion of the crops.

Where wheat-growing is conducted on a commercial basis, the size of the farms is often very great. In the Canadian North-West, farms are to be found varying in size from 1,280 to 2,560 acres, though the usual size is from 160 to 640 acres ; in the Red River Valley, in Nortr 
Dakota, there are eleven big grain farms ranging from 2,000 to 12,000 acres, well earning the name of "bonanza" farms; in the Pacific Coast States, especially in parts of California, large farms are the rule; in the Central Valley of Chile some of the "haciendas" cover as much as 30,000 acres ; and, in Argentina, there were in 1901 twenty-eight "estancias" of over 2,500 acres, and nine-tenths of the wheat area is in large blocks, varying from 1,000 to 10,000 acres. Naturally, on such farms as these the main idea has been, and is, to obtain the greatest product for the least labour and expense, and intensive farming has not been considered. Extensive farming decreases the values consumed in farm machinery, and transient labour can be more easily employed, and more effectively utilized, than on small farms with intensive cultivation.

The large ("bonanza ") farms of the United States will be broken up as population increases. This tendency is noticeable at the present time. As population increases and land grows in value, more must be allowed for rental or interest on investment, and intensive diversified farming replaces the more extensive wheat-farming. The best returns in wheat-farming accrue where one man, the owner, and one set of farm machinery do most of the work. These farms in the United States usually cover from 160 to 170 acres of land. They will doubtless drive out the "bonanza" farms with their thousands of acres, enormous machines, and small armies of labourers. In the Census year 1899, more wheat was raised on farms of 101 to 175 acres than on those of any other specified size. Less than one-eleventh part of the United States 
wheat output was grown on farms exceeding 1,000 acres, and almost one-fifth was raised on farms of less than 100 acres. Taking the whole country, the yield per acre on the smaller farms exceeded slightly the yield on the large farms, although the soil on the large farms was practically virgin. As a pioneer crop, extensive farming of wheat tends to be practised, but changing conditions, as shown in the United States, must finally result in intensive farming.

The quality of the labour employed on the wheat fields is a most important item, and depends largely on the interest taken in the land, on immigration, on nationality, and on previous training. In North America, the great majority of the farmers own their land, and where the cultivation is under the owner's personal control it becomes of importance. Though not of the standard of European cultivation, yet the yield of wheat is large in proportion to the labour spent on its production, but small in proportion to the abundant land at the disposal of the farmer. The great weakness of farming in Argentina is the lack of interest in the land taken by the cultivators, and this means the rapid exhaustion of the soil. Immigration into North America is steadily going on, especially into Canada, and the class of immigrant is on the whole good; but South American countries suffer from a lack of labour, for immigration into these countries is small, and what there is supplies a poor quality of labour. Nationality has its effects on wheat outputs; the North American farmer is energetic and intelligent, whereas in Argentina the Italian and Basque cultivators are lacking in progressiveness, intelligence, 
and business-like methods, preferring to follow the traditions of their fathers. Seed selection, the preparation of the land for sowing, and crop rotation receive little attention from them; their object is to get the most from the land by primitive methods, and when exhaustion occurs they leave the land, and pass on to exhaust other new land. The previous training of the labourers employed on the farms must receive attention. Many Italians and other immigrants from the Mediterranean countries of Europe are unaccustomed to using horses, hence their services are somewhat limited. The rural immigrants from Central and Northern Europe are, however, accustomed to the use of draught animals, and know something about handling them. In the Pacific Coast States, the Japanese and Chinese labourers cannot handle the great teams or the engines that propel the massive farm ploughs, headers, and combined harvesters. Perhaps the best example cited of the effects of previous experience acquired by the cultivators on wheat outputs is that of the rapid development of the Canadian North-West grain-fields by Canadians and Americans, who emigrated from the east and south into Saskatchewan and Alberta. These men had knowledge of similar conditions of soil and climate, and knew the best methods of cultivation to adopt; hence the rapid extension of the wheat lands of Western Canada since 1900.

The quantity of the labour employed on the farms is of prime import, especially at harvest time. It may be remarked that the preparation of the ground and the seeding are generally done without the special stress of harvesting, and may therefore be considered as accom- 
plished by ordinary labour. The harvesting of wheat, however, makes imperative temporary demands beyond the capacity of the ordinary farm help. Other grains come within the comprehensive term "harvesting," but the excessive costs pertain to wheat: cut too soon it shrinks, and left too long it is wasted in handling over much of the wheat regions. All the fields of a vicinity seem to demand help at once, and a period of two weeks in any locality will cover the stress, except in such localities as have climate and varieties, that permit ripened grain to stand longer without wasteful shrinkage or shelling. On account of the dearness of labour, and the lack of it at times of special stress, the American has used his ingenuity in lessening the difficulty by the invention and use of special farm machinery-gang ploughs, seeders, and harvesters.

The fertility of the soil, its cheapness, and the use of labour-saving machinery, are three of the main factors resulting in extensive farming in America. Had it not been for these three factors, the success and prosperity of the American farmer in the past would have been unknown. As illustrating the saving in human labour and cost by the use of modern farm machinery, it may be said that in the United States the amount of human labour now required to produce a bushel of wheat from beginning to end is, on an average, only ten minutes, whereas in 1830 the time was three hours and three minutes; and during the interval between these years the cost of the human labour required to produce a bushel of wheat declined from $17 \frac{3}{4}$ cents to $3 \frac{1}{3}$ cents.

The various processes resorted to, and the labour 
employed in the cultivation and harvesting of wheat in America, will be considered under the following heads: ploughing, seeding, harvesting, harvesters, and threshing.

The common hand-plough is most generally used in America, especially by the small farmer. With this or the sulky-plough, one man with a team of two horses can plough from one to two acres per day. On the large farms the gang-plough, which is simply a number of common ploughs on a frame, is common. The motive power is supplied either by steam or horses. Gangploughs in the Red River Valley are usually drawn by five horses, and each plough turns about 250 acres in from four to six weeks. Steam power is not used, as the nature of the ground is against it, and horses are needed for other farming operations. In the Central Valley of California ploughing is commonly done by gange of from four to fourteen ploughs, with a six or eight mule team, and from ten to fifteen acres per day can be turned by one man and his team. Ploughing and reploughing is frequently done on the very large farms by large gangs of ploughs or disks, drawn by a traction-engine, and a tremendous amount of work is accomplished in a very short time. In North-West Canada the implements used are principally two-plough gangs, drawn by from four to six horses according to the weight of the animals and the nature of the soil. Steam ploughing rigs are used largely for breaking the prairie; these consist generally of thirty horse-power traction-engines, drawing from eight to ten ploughs. The sixteen horse-power gasoline engine, which draws from four to five ploughs, is also in use. Each plough in these different styles of gangs turns as a rule 
a 14-inch furrow. The gasoline engine is also used to a considerable extent for stubble ploughing. The large steam rigs are sometimes used for ploughing stubble, in which case a packer, followed by a set of smoothing harrows, is generally drawn immediately behind the gang, thereby lessening the amount of work necessary to be done on the soil by horse-power. This last method of farming is, however, the exception.

Ploughing in Argentina is done in a very leisurely fashion; many oxen are used to draw the ploughs. Two or two and a half acres can be ploughed per day by one man with a single plough. Possibly hand ploughs will decrease in the future, on account of their expense, but at present the Argentine farmer, having practically all the year to plough in, avoids spending his money by doing his own ploughing. Experience has shown that Argentine wheat land should be ploughed twice to secure the best results after the first two years of cropping. The first ploughing is done in February, March, or April, and the second ploughing in May, June, July, or August. The authorities advise the farmers to plough 8 or 9 inches deep for the first time, and not more than 4 inches deep for the second time; these operations bring up the rich soil and bury the weeds. More than half of the wheat in Argentina is, nevertheless, planted on land that has only been ploughed once, and that just before seeding, which is done from May to August, according to the zone.

Fall ploughing in North America for spring wheat is resorted to, for it increases the yield, is most destructive to weeds and insects, and is very economical in farm 
management. For winter wheat, ploughing takes place directly after harvesting, in order to form a good seedbed, and make the soil retentive of moisture. The depth of ploughing varies with soil and climatic conditions, but the limits are usually 4 to 8 inches.

There are two methods of seeding : broad-casting, which scatters the seed evenly; and drilling, which places it in rows. Of the two methods, drilling is the more advantageous. For broad-casting the waggon-seeder is by far the best machine; by its means two men and one team are enabled to broad-cast 100 acres per day. The pressdrill is largely used in the Far West. Press-drills covering 12 feet are used in the Red River Valley. Thirty acres per day can be sown by one man with one of these drills. Broad-cast seeders are used, and broad-casting by hand is done in the Pacific Coast States. In the semi-arid parts of these states, when the crop is nearly a complete failure, and rain happens to come immediately after the harvest, the farmer sometimes scatters a little additional wheat over the ground without reploughing, and allows it to grow as a volunteer crop. Often a good yield is obtained, sometimes as high as 25 to 30 bushels per acre.

In Argentina seeding is done mostly with broad-cast seeders, though much is still done by hand. In 1901 it was estimated that 71 per cent. was done with broad-cast seeders, 12 per cent. with drills, and 17 per cent. by hand.

The amount of seed required per acre depends upon the time and method of seeding, on soil and climatic conditions, on the variety of wheat used, and its size and quality. The usual amount sown per acre in North 
America is from $1 \frac{1}{4}$ to $1 \frac{1}{2}$ bushels. According to the Department of Agriculture, Washington, the average amount sown per acre in the United States is $1 \frac{3}{8}$ bushels in the winter wheat regions, $1 \frac{1}{2}$ bushels in the spring wheat regions, $1 \frac{3}{8}$ to $2 \frac{1}{4}$ bushels in the Middle Atlantic States, $1 \frac{1}{2}$ to 2 bushels in the Mississippi and Ohio Valleys, and $\frac{3}{4}$ to 2 bushels in California. In Argentina, about 1 bushel per acre is used, and this is considered too great. The Swedish farmers around Tandil, who are very successful and prosperous, plant $\frac{5}{8}$ to $\frac{7}{8}$ bushel per acre ; while the Italians, their neighbours, plant twice as much, and are less successful.

The time of seeding varies with soil, climate, and latitude. Spring wheat is sown as soon as the ground is in a fit state for seeding. Early seeding is of great importance. Dr. William Saunders says: "The average of ten years" experience in early, medium, and late sowing at Ottawa has shown that with wheat a delay of one week after the ground is in good condition to receive the seed has entailed a loss of over 30 per cent. ; two weeks, 40 per cent. ; three weeks, nearly 50 per cent. ; and four weeks, 56 per cent. of the crop." Winter wheat in North America is usually sown in the months of September, October, and November. Seeding in Argentina begins at the end of autumn-about May 15 in the north and centre of Santa Fé, Entre Rios, and Cordoba-and ends in August in Southern Buenos Aires, and the territories of Rio Negro, Pampa, Neuquen, and Chubut. In Chile wheat is sown in May, June, and July.

After the ground has been ploughed once, harrowing is commonly practised. This results in the killing of weeds, 
the levelling of the surface, and the covering of the seed. Harrows 25 feet in width are used on the very large farms, and it is possible with one such harrow for a man with four horses to cover 60 to 75 acres per day. Harrowing is of great utility on the older cultivated parts of the prairies, for it produces a loose soil mulch for the conservation of moisture, and aids in the processes of subsoil packing.

Cultivation by one operation is usual in parts of California. Gang ploughs, to which are attached broad-cast seeders and harrows, and which are drawn by powerful traction-engines, make it possible to cover a large acreage. Even a small outfit, operated by one man and a team of eight mules, will plough, sow, and harrow in the seed in one operation at the rate of from 10 to 15 acres per day.

The labour expended on wheat-raising obtains no reward till the harvest, and till the invention of modern harvesting machinery, harvesting was necessarily a most exacting operation. In the Canadian North-West and on the "bonanza" farms of the United States harvesting reaches its highest magnitude. Of necessity the bulk of the work on the large farms must be done by transient labourers. In North America harvesting commences in the southern states in the middle of June, and ends in North-West Canada in the middle of September. The harvesters usually work their way northwards; they are often foreigners, and their personnel is very varied, but they are usually steady, industrious men. Harvesting in Argentina is a great task. The chief trouble is to get sufficient help during the harrest. Prices of labour at 
this time are usually high, and men are hard to find. The poor farmer, who has planted more than he and his family can care for, finds it very difficult to save his crop.

It is interesting to note the various harvest seasons in America :

$$
\begin{array}{llll}
\text { January } & . & \text { Chile. } \\
\text { February } & . . & \text { Mexico. } \\
\text { April } & \ldots & \text { Mexis. } \\
\text { May } & \ldots & \text { Texas. }
\end{array}
$$

June _. Alabama, Arkansas, California, Georgia, Kansas (winter wheat), Kentucky, Maryland, Illinois, Missouri, Nebraska (winter wheat), North Carolina, South Carolina, Oklahoma, Tennessee, Virginia, and Indiana.

July . . Wisconsin, West Virginia, Washington, South Dakota, Pennsylvania, Oregon (winter wheat), New York, Nebraska (spring wheat), Colorado (winter wheat), Iowa (winter wheat), Kansas (spring wheat), Michigan, and Upper Canada.

August .. Idaho (winter wheat), North Dakota, Oregon (spring wheat), Minnesota, Lower Canada, and North-West Canada.

September.. Washington, Idaho, and North-West Canada (early September).

November.. Northern Argentina and Peru.

December.. Southern Argentina.

Professor Hunt, in his work, "Cereals in America," says that a good test for judging the time for cutting wheat is that the kernel should be soft enough to be easily indented with the thumb-nail, and hard enough not to be easily crushed between the fingers. The time to cut is of exceptional importance to the farmers, unless climatic conditions like those of California exist, where the wheat may be allowed to stand some weeks after it 
is ripe without much loss ensuing. Great advances have been made in comparatively recent years in harvesting machinery in America. On the western grain farms of the United States, and even in some parts of the Mississippi Valley, the modern header is largely used, as the peculiar climatic conditions allow the wheat to ripen completely without much danger of loss. The header clips the stalk a few inches below the head of the grain, but it is possible to cut lower by its means for lodged or short grain. No binding or shocking is necessary, but the wheat must be dry before it is cut, and threshing must follow immediately. To save time and to lessen risks, some wheatgrowers cut with binders until the grain is ripe, and then use the header. Usually the header cuts from 12 to 20 feet in width, and from 13 to 50 acres per day. In Argentina about 15 per cent. of the wheat is cut with headers, chiefly in the province of Santa Fé. Owing to the uneven height of the grain, the headers are set to cut anywhere from 6 to 18 inches of straw. Formerly the header was used very extensively in the Pacific Coast States, but the combined harvester has largely supplanted it. The self-binding harvester is a machine which delivers the grain bound in sheaves. It can easily be adjusted to variations in the grain and to the surface of the wheat field. The usual width cut is about 6 feet. These machines are used chiefly on the smaller farms, and on rough ground. One man and three horses can harvest with the binder from 10 to 20 acres per day, and two men are necessary to set up the sheaves. In NorthWest Canada the harvesting is done by self-binders, of which there are three sizes, cutting respectively 6,7 , and 
8 feet swaths. The largest is in most general use in districts where wheat is grown extensively. The header is seldom used, for it is found that to get a good sample it is necessary for the grain to remain in stook for a period of from fifteen to twenty days before threshing. The header binder used in North Dakota, South Dakota, Kansas, Oklahoma, the Pacific Coast States, and Argentina, is merely a binder attached to the header.

The combined harvester-thresher is the most wonderful of modern harvest machinery. It not only cuts, gathers, threshes, and cleans the wheat, but even sacks the grain, without a touch from man's hand. The only human labour required is in sewing up the sacks. Either steam or horse power can be employed. Its one great disadvantage is that it can only be used to advantage in a dry climate. Where grain is matured under the influence of an oceanic climate, it cannot be used. The combined harvester-thresher, commonly known as the "stripper," has been introduced into Argentina. For non-shattering and dry wheat the use of this machine is a distinct saving in cost. By its means the heads are stripped from the stalks standing in the field by a comb, having the appearance of a sickle-guard, and taking a 5-foot swath. The straw is left standing where it grew. One man can easily operate this machine, with a boy to ride the lead horse, and in one day it is possible to cut and thresh the grain from 6 to 10 acres. The machine usually requires from four to seven horses to work it.

It is a novel and interesting sight to the European to watch the harvesting operations in the "Inland Empire" -a name applied to the Pacific North-West east of the 
Cascades and Sierras. The ponderous harvester sweeps through miles upon miles of ripened grain, cutting swaths from 16 to 42 feet in width, harvesting, cleaning, threshing, and leaving behind a long trail of sacked grain, ready to be hauled to the warehouse, railroad, or mill. The combined harvester and thresher of California is usually drawn by from twenty-four to forty horses; it harvests and sacks from 25 to 45 acres per day, and requires four men to operate it. By its use grain is threshed directly from the field, and left piled in sacks, containing about $2 \frac{1}{2}$ bushels each. The standard horse machine, which is commonly used, cuts a swath from 16 to 20 feet wide; and the combined steam outfit of traction-engine and harvester has a cutting bar from 24 to 42 feet long. It harvests from 60 to 125 acres per day, and requires eight men to operate it. The tractionengine or motive power is independent of the harvester proper, and is usually of 110 horse-power.

On the large farms where the self-binder is used, the grain is never stacked, as is generally done on the small farms, but is hauled directly from the field to the steamthresher. Straw is used for fuel in the engine, and one man is kept busy pushing it into the furnace. Only a small fraction of the straw, however, is used in this way. The remainder is usually burnt in heaps, for the Western farmers of Canada and the United States have no use for straw. Most of the threshing in America is done by steam. Some farmers own their own machines, but usually the threshing is done for a stated price per bushel by the travelling outfit. Generally 500 to 1,000 bushels per day are threshed on the moderate-sized farms. In 
California the combined harvester-thresher can stack the grain at the rate of 1,600 sacks per day.

From the foregoing account it is evident that the American farmer is largely guided in his operations by the scarcity and dearness of human labour, and that his main endeavour is to make the land yield the maximum return for the minimum cost. 


\section{CHAPTER VI}

\section{YIELD AND COST OF PRODUCTION}

THE yield of wheat depends upon many factors. The natural factors, soil and climate, have been shown to be very potent in effect, and to them are mainly to be assigned the variations in yield in various seasons. Wheat yields per acre in America are far from approaching those of European countries with their intensive system of farming, and higher yielding breeds of wheat. As population increases in America, the tendency will be towards intensive and diversified farming, and the yields will doubtless increase and approximate closely to those of Europe.

Argentina's statistics, which may be considered as approximately correct, show that her wheat yields are but moderate. It canrot be expected that they will very materially increase until her cultivators become better educated, and thus able to appreciate modern scientific farming methods, or till the pressure of population shall compel them to farm better. Conditions such as these involve slow growth.

The following tables give the yields in bushels per acre in the most important wheat regions in America : 


\begin{tabular}{|c|c|c|}
\hline \multicolumn{2}{|c|}{ 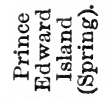 } & | | | | | | | | | | | 용요 \\
\hline \multicolumn{2}{|c|}{ 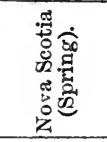 } & 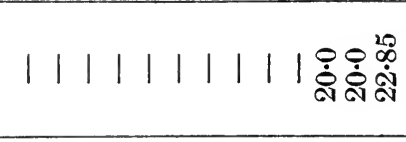 \\
\hline \multicolumn{2}{|c|}{ 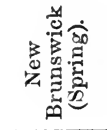 } & | | | | | \\
\hline \multicolumn{2}{|c|}{ 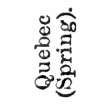 } & 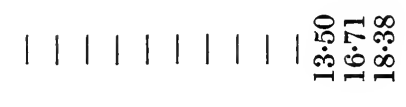 \\
\hline \multirow{2}{*}{ 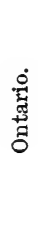 } & 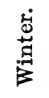 & 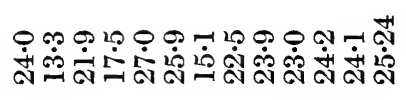 \\
\hline & 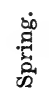 & 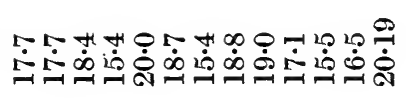 \\
\hline \multirow{2}{*}{ 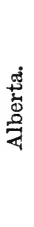 } & 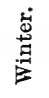 & | | | | | \\
\hline & 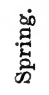 & 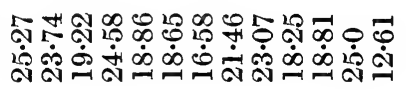 \\
\hline \multicolumn{2}{|c|}{ 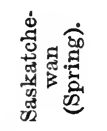 } & 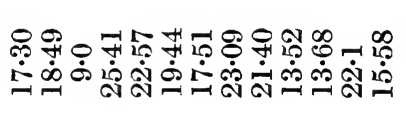 \\
\hline \multicolumn{2}{|c|}{ 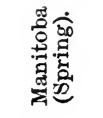 } & 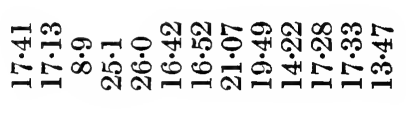 \\
\hline \multicolumn{2}{|c|}{ 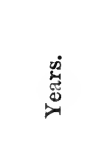 } & 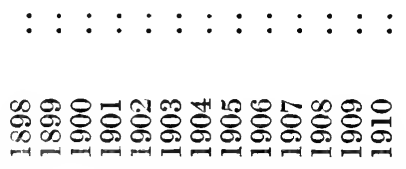 \\
\hline
\end{tabular}

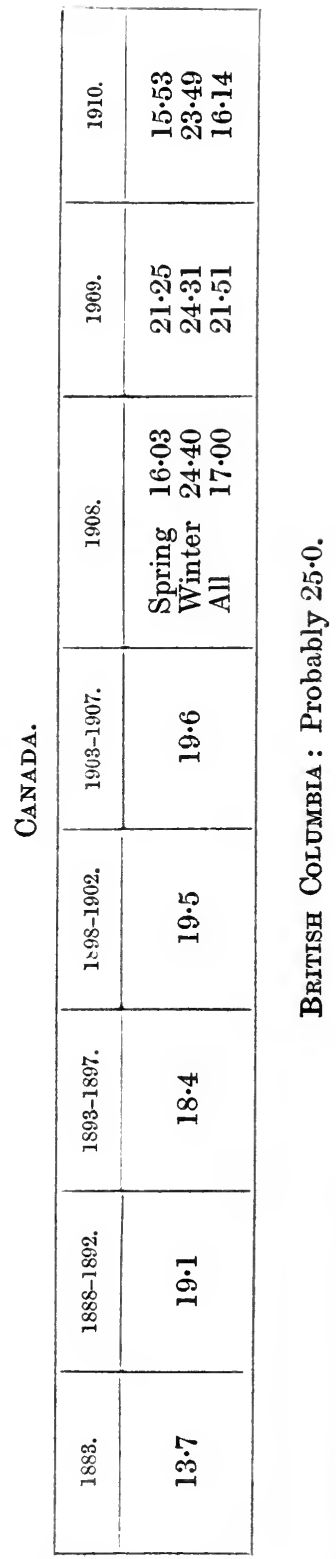


United States.

\begin{tabular}{|c|c|c|c|c|}
\hline & Years & & Winter Wheat. & Spring Wheat. \\
\hline $\begin{array}{l}1886 \\
1887 \\
1888 \\
1889 \\
1890\end{array}$ & $\begin{array}{l}\ddot{ } \\
\cdots \\
\cdots \\
\cdots\end{array}$ & $\begin{array}{l}\cdots \\
\cdots \\
\cdots \\
\ldots\end{array}$ & $\left.\begin{array}{r}1886-1890: \\
12 \cdot 3 \\
12 \cdot 1 \\
11 \cdot 6 \\
13 \cdot 9 \\
10 \cdot 9\end{array}\right\} 12 \cdot 16$ & $\left.\begin{array}{l}1886-1890: \\
12 \cdot 6 \\
12 \cdot 2 \\
10 \cdot 3 \\
12 \cdot 4 \\
11 \cdot 4\end{array}\right|^{\mid} 11 \cdot 78$ \\
\hline $\begin{array}{l}1891 \\
1892 \\
1893 \\
1894 \\
1895\end{array}$ & $\begin{array}{l}\cdots \\
\cdots \\
\cdots \\
\ldots\end{array}$ & $\begin{array}{l}\cdots \\
\cdots \\
\cdots \\
\cdots\end{array}$ & $\left.\begin{array}{r}1891-1895: \\
14 \cdot 7 \\
13 \cdot 7 \\
12 \cdot 0 \\
14 \cdot 0 \\
11 \cdot 6\end{array}\right\} 13 \cdot 2$ & $\left.\begin{array}{r}1891-1895: \\
16 \cdot 7 \\
12 \cdot 7 \\
10 \cdot 2 \\
11 \cdot 5 \\
18 \cdot 0\end{array}\right\} 13 \cdot 82$ \\
\hline $\begin{array}{l}1896 \\
1897 \\
1898 \\
1899 \\
1900\end{array}$ & $\begin{array}{l}\cdots \\
\cdots \\
\cdots \\
\cdots\end{array}$ & $\begin{array}{l}\cdots \\
\cdots \\
\cdots \\
\cdots\end{array}$ & $\left.\begin{array}{r}1896-1900: \\
11 \cdot 8 \\
14 \cdot 1 \\
14 \cdot 9 \\
11 \cdot 5 \\
13 \cdot 3\end{array}\right\} 13 \cdot 12$ & $\left.\begin{array}{r}1896-1900: \\
13 \cdot 5 \\
12 \cdot 5 \\
16 \cdot 0 \\
13 \cdot 3 \\
10 \cdot 6\end{array}\right\} 13 \cdot 18$ \\
\hline $\begin{array}{l}1901 \\
1902 \\
1903 \\
1904 \\
1905\end{array}$ & $\begin{array}{l}\cdots \\
\cdots \\
\cdots \\
\cdots\end{array}$ & $\begin{array}{l}\cdots \\
\cdots \\
\cdots \\
\ldots\end{array}$ & $\left.\begin{array}{r}1901-1905: \\
15 \cdot 2 \\
14 \cdot 4 \\
12 \cdot 3 \\
12 \cdot 4 \\
14 \cdot 3\end{array}\right\} 13 \cdot 72$ & $\left.\begin{array}{r}1901-1905: \\
14 \cdot 7 \\
14 \cdot 7 \\
14 \cdot 0 \\
12 \cdot 8 \\
14 \cdot 7\end{array}\right\} 14 \cdot 18$ \\
\hline $\begin{array}{l}1906 \\
1907 \\
1908 \\
1909 \\
1910\end{array}$ & $\begin{array}{l}\cdots \\
\cdots \\
\cdots \\
\cdots\end{array}$ & $\begin{array}{l}\cdots \\
\cdots \\
\cdots \\
\cdots\end{array}$ & $\left.\begin{array}{r}1906-1910: \\
16 \cdot 7 \\
14 \cdot 6 \\
14 \cdot 4 \\
15 \cdot 8 \\
15 \cdot 8\end{array}\right\} 15 \cdot 46$ & $\left.\begin{array}{r}1906-1910: \\
13 \cdot 7 \\
13 \cdot 2 \\
13 \cdot 2 \\
15 \cdot 8 \\
11 \cdot 7\end{array}\right\} 13 \cdot 52$ \\
\hline
\end{tabular}

All Wheat.

\begin{tabular}{|c|c|c|c|}
\hline $371-1880$ & & & \\
\hline-1890 & . & & \\
\hline $\begin{array}{l}891-1900 \\
901.1910\end{array}$ & & & \\
\hline
\end{tabular}


Aver age Yield per Aore of Wheat in the United States.

\begin{tabular}{|c|c|c|c|c|c|}
\hline \multirow[t]{2}{*}{ T } & \multicolumn{4}{|c|}{ Ten-Year Averages. } & \multirow{2}{*}{$\begin{array}{c}\begin{array}{c}\text { Four. Year } \\
\text { Average. }\end{array} \\
1906-1909 .\end{array}$} \\
\hline & 1866.1875. & $1876-1885$ & 1886-1895. & 1896-1905. & \\
\hline $\begin{array}{l}\text { North Atlantic Sta } \\
\text { Maine } \\
\text { New Hampshire } \\
\text { Vermont } \\
\text { Connecticut } \\
\text { New York } \\
\text { New Jersey } \\
\text { Pennsylvania }\end{array}$ & $13 \cdot 7$ & $14 \cdot 1$ & $14 \cdot 1$ & $16 \cdot 3$ & $18 \cdot 25$ \\
\hline $\begin{array}{l}\text { South Atlantic Sta } \\
\text { Delaware } \\
\text { Maryland } \\
\text { Virginia } \\
\text { West Virginia } \\
\text { North Carolina } \\
\text { South Carolina } \\
\text { Georgia }\end{array}$ & $8 \cdot 9$ & $8 \cdot 9$ & $9 \cdot 0$ & $10 \cdot 6$ & $12 \cdot 7$ \\
\hline $\begin{array}{c}\text { North Central Sta } \\
\text { East of the M } \\
\text { issippi River : } \\
\text { Ohio } \\
\text { Indiana } \\
\text { Illinois } \\
\text { Michigan } \\
\text { Wisconsin }\end{array}$ & $12 \cdot 3$ & $13 \cdot 9$ & $14 \cdot 2$ & $13 \cdot 3$ & $16 \cdot 8$ \\
\hline $\begin{array}{c}\text { North Central Sta } \\
\text { West of the M } \\
\text { issippi River : } \\
\text { Minnesota } \\
\text { Iowa } \\
\text { Missouri } \\
\text { North Dakota } \\
\text { South Dakota } \\
\text { Nebraska } \\
\text { Kansas }\end{array}$ & $13 \cdot 1$ & $11 \cdot 9$ & $13 \cdot 0$ & $13 \cdot 0$ & $13 \cdot 6$ \\
\hline $\begin{array}{l}\text { South Central Stat } \\
\text { Kentucky } \\
\text { Tennessee } \\
\text { Alabama } \\
\text { Mississippi } \\
\text { Texas } \\
\text { Oklahoma } \\
\text { Arkansas }\end{array}$ & $8 \cdot 6$ & $8 \cdot 2$ & $9 \cdot 7$ & $11 \cdot 5$ & $11 \cdot 2$ \\
\hline
\end{tabular}


Average Yield per Acre of Wheat in the United States-continued.

\begin{tabular}{|c|c|c|c|c|c|}
\hline & \multicolumn{4}{|c|}{ Ten-Year Averages. } & \multirow{2}{*}{$\begin{array}{c}\begin{array}{c}\text { Four-Year } \\
\text { Average. }\end{array} \\
1906-1909 .\end{array}$} \\
\hline & $1866-1875$. & 1876.1885 & 1886.1895. & 1896-1905. & \\
\hline $\begin{array}{l}\text { Far Western St } \\
\text { Montana } \\
\text { Wyoming } \\
\text { Colorado } \\
\text { New Mexico } \\
\text { Arizona } \\
\text { Utah } \\
\text { Nevada } \\
\text { Idaho } \\
\text { Washington } \\
\text { Oregon } \\
\text { California }\end{array}$ & $15 \cdot 4$ & $14 \cdot 3$ & $13 \cdot 9$ & $16 \cdot 8$ & $21 \cdot 6$ \\
\hline
\end{tabular}

Argentina: Wheat Yields (Five-Year Averages).

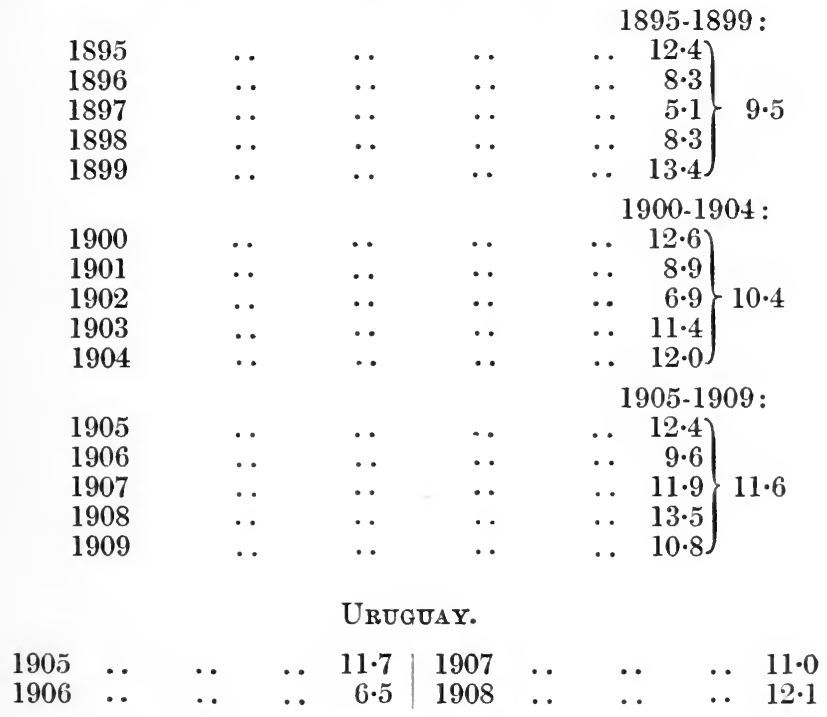


Statistics for Chile and Mexico are not available. The probabilities are that the yield varies from 7 to 16 bushels per acre, depending largely on the climatic conditions.

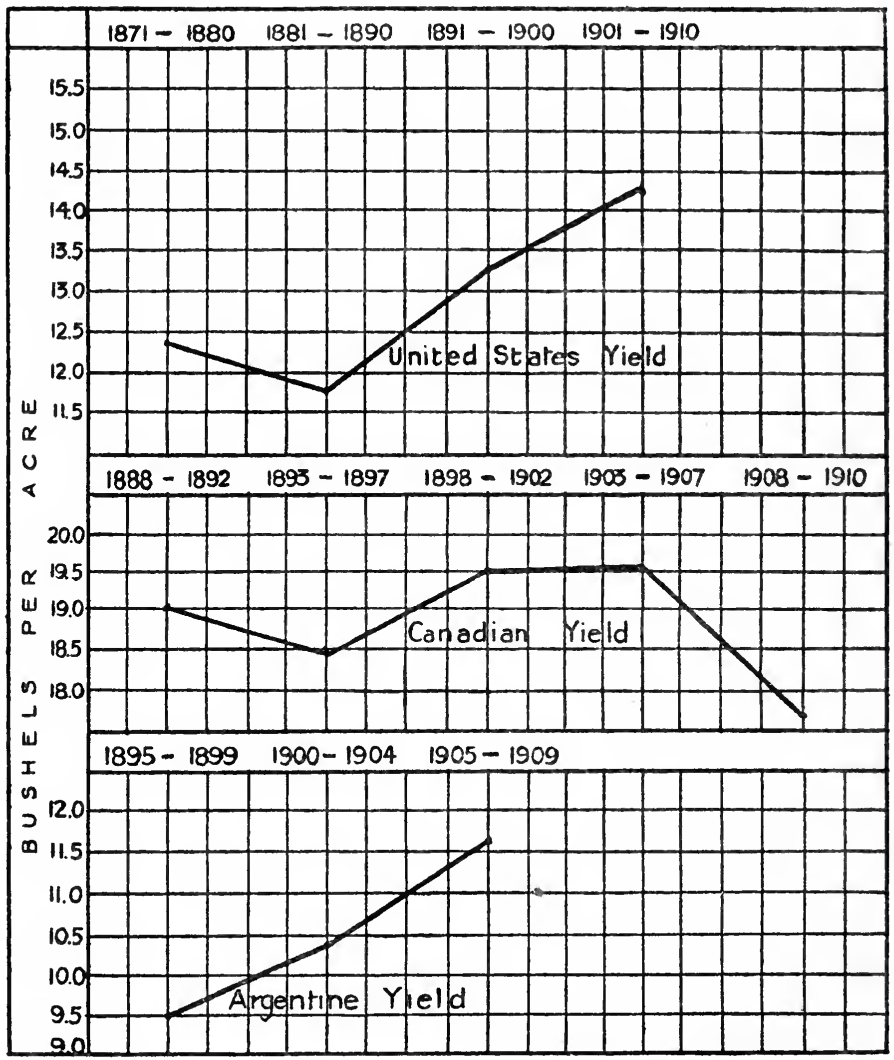

Fig. 15.-Wheat Yields : Bushels Per Acre.

It will be noticed that Canadian yields are approximately 5 bushels per acre more than any of the other countries of America ; this is largely due to the favourable soil and climate of Canada. Compared with the 
British yield of 30 to 35 bushels per acre, it is evident that America on her present exploited lands could yield a crop at least one-third greater than is now produced, notwithstanding the fact that many American wheats are not good croppers.

It is important to notice that wheat yields per acre have increased during the later decades, and this would seem to indicate that farming methods are improving.

The tables giving United States' yields illustrate well the effect of moist climates on the yield of wheat; all the soft wheat districts have a comparatively high yield. Climate accounts largely for the variation in yields, but poor farming operations and soil account to some extent for diminished yields in the South Atlantic States. Striking features of the tables are the slight average difference of yield between winter and spring wheat, and the small yield as compared with that of Canada.

Poor cultivation, poor seed, and to some extent climatic factors account for the small yields in the South American Republics and Mexico.

It would be of much interest and of practical importance if the cost of producing a bushel of wheat on the various wheat fields could be accurately gauged. The various factors, however, governing wheat production, are so complex and variable, that it is not possible to give a practical formula for the gross receipts and net profit of each harvest of wheat. It is difficult to determine the money value of some of the factors of production, while other factors, such as cost of labour and rent, can often only be approximately estimated.

Naturally the cost varies in the different wheat fields. Efforts have always been directed towards lessening the 
cost of production, and success has largely been achieved by the aid of modern farm machinery. The actual profit on raising wheat is usually not very large; it seldom happens that the "bonanza" farmer secures more than 8 per cent. interest on his capital. In 1894, the farmers of the United States even declared that the price at which their wheat was sold did not cover the cost of production.

It will be noticed from the tables which follow that Argentina compares favourably with the other countries of America as regards cost of production.

\begin{tabular}{|c|c|c|c|c|}
\hline & $\begin{array}{l}\text { Argentina, } \\
\text { 1904.* }\end{array}$ & $\begin{array}{c}\text { Kansas, } 1902 \\
\text { (Winter } \\
\text { Wheat). } \dagger\end{array}$ & $\begin{array}{c}\text { Red River } \\
\text { Valley, } 1902 \\
\text { (Spring } \\
\text { Wheat). } \downarrow\end{array}$ & $\begin{array}{c}\text { Minnesota, } \\
1890-1900 \\
\text { (Spring } \\
\text { Wheat). } \S\end{array}$ \\
\hline Preparing the land: & & & \multirow{5}{*}{$\$ 0.70$} & \\
\hline Miscellaneous .. & $\$ 0.18$ & $\$ 1.24$ & & $\$ 1.15$ \\
\hline Ploughing & $\$ 0.64$ & $\$ 0.96$ & & $\$ 1.00$ \\
\hline Harrowing & $\$ 0.18$ & $\$ 0.28$ & & $\$ 0.15$ \\
\hline \multicolumn{4}{|l|}{ Seeding : } & \\
\hline Drilling or seeding & $\$ 0.09)$ & & \multirow{2}{*}{$\$ 1.00$} & \multirow{2}{*}{$\$ 1.05$} \\
\hline Seed $\quad \ldots \quad \ldots$ & $\$ 0.89$ j & $\$ 0.92$ & & \\
\hline \multirow{3}{*}{$\begin{array}{l}\text { Harvesting. . } \\
\text { Threshing and put- } \\
\text { ting into bin .. }\end{array}$} & $\$ 2.12$ & $\$ 1.36$ & $\$ 0.60$ & $\$ 1.90$ \\
\hline & $\$ 220$ & $\$ 160$ & $\$ 150$ & $\$ 150$ \\
\hline & $\$ 0.39$ & $\$ 1.90$ & $\$ 1.00$ & $\$ 1.40$ \\
\hline Interest on machinery & $\$ 0.89$ & $\$ 0.29$ & - & $\$ 0.20$ \\
\hline Interest $\quad .$. & - & - & $\$ 2.28$ & - \\
\hline $\operatorname{Tax} \ldots \quad \ldots$ & $\$ 0.71$ & 一 & $\$ 0.25$ & $\$ 0.30$ \\
\hline Total cost .. & $\$ 8.29$ & $\$ 7.31$ & $\$ 8.28$ & $\$ 6.50$ \\
\hline $\begin{array}{ccc}\text { Cost of raising } & \text { per } \\
\text { bushel } & . & . .\end{array}$ & $\begin{array}{c}\$ 0.52 \\
(16 \text { bushels } \\
\text { to the acre })\end{array}$ & $\begin{array}{c}\$ 0.37 \\
(20 \text { bushels } \\
\text { to the acre })\end{array}$ & $\begin{array}{c}\$ 0.46 \\
(18 \text { bushels } \\
\text { to the acre })\end{array}$ & $\begin{array}{c}\$ 0.64 \\
\text { (over 10 } \\
\text { bushels to } \\
\text { the acre) }\end{array}$ \\
\hline
\end{tabular}

$\$=$ U.S.A. dollar of about $4 \mathrm{~s} .2 \mathrm{~d}$.

* United States Bureau of Statistics, Bulletin 27.

† State Board of Agriculture. $\ddagger$ "Encyclopædia Britannica."

$\S$ United States Bureau of Statistics, Bulletin 48. 
The cost of raising a bushel of wheat in England has not been estimated in recent years ; probably it is slightly over twice the cost of that in America. In 1885 the cost was given as $\$ 1.45$ per bushel.

Agrioultural Investigations, Argentina, 1904.

Province of Buenos Aires.

Farming by colonists $\quad . \$ 0.54$ (yield, 15 bushels per acre).

Farming by colonists .. \$0.64 , 12

Farming with hired labour.. $\$ 0.72$ to $\$ 0.84$ (yield, 12 bushels per acre).

Province of Santa Fé.

Farming with hired labour.. $\$ 0.78$ (yield, 15 bushels per acre).

Farming by the colonist

on his own land .. .. $\$ 0.52$

Farming by the colonist on leased land $\quad . . \quad$.. $\$ 0.69$

Alberta, Canada, 1909 (Department of Agriculture).

Winter Wheat.

Interest on investment, two years.

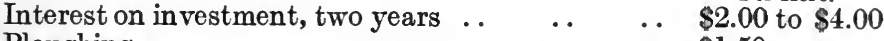

$\begin{array}{llllllll}\text { Ploughing } & . & . . & . & \ldots & . . & \ldots & \$ 1.50\end{array}$

Packing (recommended, but not always practised) $\$ 0.30$

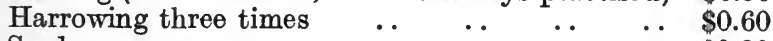

$\begin{array}{lllllllll}\text { Seed } & . & . . & . & . . & . & . . & . . & \$ 0.80 \text { to } \$ 1.50\end{array}$

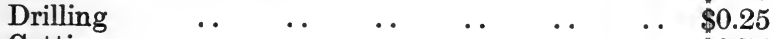

$\begin{array}{llllllll}\text { Cutting } & . . & . . & . & . . & . & \ldots & \$ 0.75\end{array}$

$\begin{array}{llllllll}\text { Twine } . . & . . & . . & . & . . & . . & . . & \$ 0.35\end{array}$

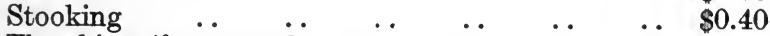

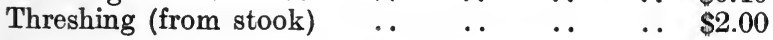

These figures are based upon the estimated yield of about thirty to thirty-five bushels per acre.

Total cost per acre $=\$ 8.95$ to $\$ 9.5$.

Cost per bushel $=30$ to 35 cents.

The cost of growing an acre of spring wheat following a crop of fall wheat varies from $\$ 7.50$ to $\$ 10.00$ per acre, according to the care taken in preparing the ground, and the friability of the ground. The crop on such land 
will vary from 15 to 25 bushels per acre of wheat, according to the season, the nature of the soil, and the care taken in preparing it.

$$
\text { Cost per bushel }=\$ 0.50 \text { to } \$ 0.60 \text {. }
$$

Argentina (British Board of Agriculture Journal, November, 1908).

Cost of preparing one acre of land for wheat: $\quad £$ s. $d$. $\begin{array}{lllllllll}\text { Ploughing .. } & . . & . . & . & . . & . . & 0 & 1 & 91\end{array}$ \begin{tabular}{lllllllll} 
Harrowing.. &.. &.. &.. &.. &.. & 0 & 0 & 6 \\
\hline 3
\end{tabular} $\begin{array}{llllllllll}\text { Sundries } & . . & . . & . & . . & . . & . . & 0 & 0 & 2\end{array}$

Sowing :

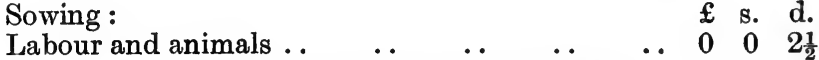
Seed (53 pounds at $6 \mathrm{~s} .3 \mathrm{~d}$. per hundredweight).. $\quad 0 \quad 2 \quad 211 \frac{1}{2}$ $\begin{array}{llllllllll}\text { Harowing } & . . & . . & . . & . . & . . & . . & 0 & 0 & 7 \frac{1}{2}\end{array}$ $\begin{array}{lllllllll}\text { Rolling, etc. } & . . & . . & . . & . . & \ldots & 0 & 0 & 8 \frac{1}{2}\end{array}$

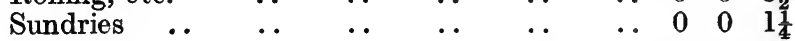

Harvesting :

Machinist, stacker, and assistant, loading, food, $f$ s. d.

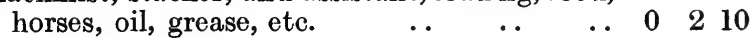

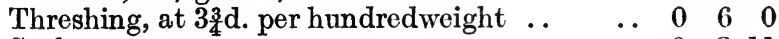

$\begin{array}{llllllllll}\text { Sacks } & \text {. } & \text {.. } & . . & \text {.. } & \text {.. } & \text {.. } & 0 & 2 & 11 \frac{1}{2}\end{array}$

\begin{tabular}{lllllll} 
Cartage to railway-station &.. & .. & .. & 0 & 1 & 11 \\
\hline
\end{tabular}

General expenses :

$\begin{array}{lllllll}\text { Maintenance of labourers } & \ldots & \text {. } & \text {.. } & 0 & 7 & 1\end{array}$

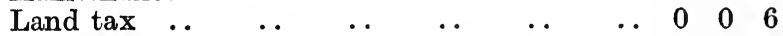

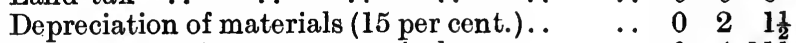

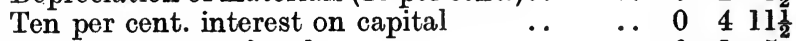

Interest on cost of tools ..

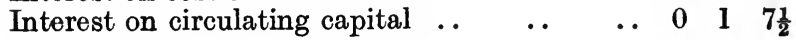

£1 $11 \quad 5 \frac{3}{4}$

Total cost per acre $=£ 118 \mathrm{~s} .7 \mathrm{~d} .=\$ 9.26$.

Profit to the farmer is about $\$ 3$ to $\$ 4$ per acre.

Cost per bushel $=50$ cents to 60 cents (approximately). 


\section{CHAPTER VII}

\section{THE TRANSPORTATION OF WHEAT}

THE transportation of wheat is almost as important as its production, for otherwise wheat has little value either to grower or consumer. Before the construction of the Erie Canal, Genesee wheat was scarcely more than the bread of a few pioneers, and it was not till after 1860, when railroad construction was great, and lake navigation had been developed, that wheat production made great strides in the United States. History is now repeating itself in the Canadian North-West, in the multiplication of trunklines and spurs, in the extension of through lines of transportation from Europe to the St. Lawrence, from the St. Lawrence to the Pacific, and from Vancouver and Prince Rupert to the Far East. Argentina has also greatly developed her railway systems, but the rapidity with which the extension of grain production came upon her has left her transportation arrangements far behind those of the United States and Canada, and confusion of traffic often results.

Usually there are four stages in the transportation of wheat:

1. Transportation from the farm to the local market.

2. Transportation from the local market to the primary market. 
3. Transportation from the primary market to the seaboard.

4. Transportation from the seaboard to the foreign market.

\section{Transportation from the Farm to the LOCAL Market.}

The question of good roads looms largely in the conveyance of grain to the local market ; it affects the farmer's profits, and sometimes determines when the grain shall be sold. Roads are fairly good in the more settled parts of Canada and the United States, but in Argentina they are almost wholly neglected.

Animal power is almost universally employed in carrying wheat to the local markets, largely because of the state of the roads, and the use of animals on the farms. In Argentina and the Pacific Coast States all wheat is handled in sacks, after being threshed; whereas in other parts, such as the Red River Valley, wheat runs directly from the thresher into the waggon-box or grain-tank. In most parts of North America, because of the flowing quality of wheat, advantage is taken of handling it in bulk (loose condition) as soon as it reaches the elevator.

It is a common practice in the North Central States of the United States to haul wheat direct from the thresher to the car. The grain is loaded as rapidly as threshed, and each waggon in turn is driven to the shipping point, where a waggon-dump is often used for unloading the grain. This dump is a platform, on which a loaded waggon is driven, the end gate of the waggon-box removed, and the parts of the platform upon which the 
hind wheels of the waggon rest are lowered, so that the grain falls into the space below. It may be received into a bin under the platform for temporary storage, or may be conveyed into a chute that leads to the basement of an elevator. By steam-power the wheat ascends, and is cleaned, sorted, mixed, weighed, and stored. By the force of gravity it descends into sacks for loading, or loose into cars alongside the elevator.

According to the Bureau of Statistics, Department of Agriculture, Washington, the average load of wheat hauled from the farms to the local markets in the North Central States in 1906 was 3,077 pounds.

Large waggons with broad tyres, and drawn by teams of four, five, or six horses, enable farmers to carry their products to local markets in loads of two or more tons each. A large outfit is of prime importance where wages of labour are high, or where the farmer wishes to sell quickly because of low freight rates or a rising market.

Hired freight waggons are in general use in the Far West, and, to lessen the charges for labour, two or more waggons are often coupled together. Sometimes the load of grain is as much as 7 tons.

The haulage distance to the local market, whether elevator or railway-station, varies greatly; in the newer settled districts of America it may be forty to fifty miles.

The wheat country of Argentina is nearly perfectly flat, with scarcely a knoll or depression, but this advantage for transportation is offset by poor and muddy roads. During the marketing season (January to May), progress over the mud roads is slow and expensive. Immense two or four wheeled carts, having wheels 
8 feet in diameter, are used, and the horses, mules, or bullocks employed, which may number as many as sixteen, are fastened to the carts in a very primitive fashion. The load of grain usually weighs from 4 to 6 tons, and the coarse jute bags containing the grain are carried up into the waggons by men. Argentine wheat-growers rarely haul their grain to market, unless they are near to a station, but employ men, who make a business of it.

\section{Transportation from local Market to Primary Market.}

The primary markets are the great railway centres, into which the surplus wheat is concentrated from the local markets. Among the largest of these centres are : Chicago, Minneapolis, Winnipeg (elevators at Port Arthur and Fort William), Duluth, Superior, St. Louis, Milwaukee, Toledo, Kansas City, Peoria, Omaha, Cincinnati, and Detroit. Minneapolis receives annually about $90,000,000$ bushels of wheat. From each primary market railway lines radiate in all directions, and there is keen competition between the various railway companies. Water transportation is very small. The box cars used on the United States railways have an average capacity of about 1,100 bushels of wheat, and sometimes a train will haul sixty such cars.

\section{Transportation from Primary Market to} Staboard.

The movement of wheat from the primary market to the seaboard is sometimes all rail, and at other times by rail, lake, and canal. The Great Lakes traffic in grain is 
immense. Large vessels, engaged in freight-carrying on the Great Lakes, convey cargoes weighing as much as 300,000 to 400,000 bushels of wheat. Canals and rivers, largely used before the railway era, have lost their old importance, but the future may see more use made of them.

\section{Transportation from Seaboard to Foreign MARKeT.}

The exportation of American wheats became of great importance about the middle of the nineteenth century. Europe's decreased cereal production provided America with her opportunity. The development of the wheat exportation of America has depended on Europe's extremity in grain, the laying of the Atlantic cable, the commercial grading of wheat, the economies of the elevator system, and modern transportation methods.

For convenience, the transportation of wheat in the various countries will now be considered separately.

\section{Canada.}

Canada, as a large grain-exporting country, came into prominence largely owing to the laying down of the Canadian Pacific Railway. She possesses a splendid system of waterways, and canal construction has been very active in the region of the Great Lakes. Attention is now being concentrated on her railways, and efforts are being made to spread a network of railways over the vast wheat regions of the west.

The problem of wheat transportation begins when the crop has been reaped, and the grain threshed. Where the 
farmer is conveniently placed near the local market there is little difficulty; but where the farm is small and at a distance from the station, it is sometimes impossible for the farmer to draw his grain to the railway without suspending all other work on the farm. In the most unfavourable cases the farmer has frequently to choose between preparing his land for the next crop, and marketing his wheat; for the interval between harvest-time and the commencement of winter is too short for him to do both together. $\mathrm{He}$ therefore often waits until the frost prevents further ploughing; then it is easy for him to draw his wheat on sleighs to the elevator or railway car, for the frost makes even the worst roads good. The most favourable conditions exist in Southern Manitoba, on the main line of the Canadian Pacific Railway, and the least favourable in the newer settled districts, where farms are from twenty-five to fifty miles from a station, and where the prairie trails are heavy, and sometimes impassable.

Winnipeg is the great wheat market of North-West Canada, though its " bases of supplies"-the elevators at Port Arthur and Fort William-are 420 miles away. Its position makes it the natural market-place for the crops of the Canadian West. Its importance in the grain traffic may be gauged from the fact that it handles $200,000,000$ bushels of grain annually.

There are five great railway systems in Canada-the Intercolonial, the Canadian Pacific, the Grand Trunk, the Canadian Northern, and the Great Northern. The Intercolonial connects Montreal, the commercial metropolis of Canada, with the winter ports of St. John, Halifax, and Sydney, in the Maritime Provinces. The Canadian 
Pıcific Railway runs from Halifax and St. John to quebec and Montreal. From Montreal it follows the Ottawa River, then through a forest region to Sudbury, and on to Port Arthur and Fort William, on Lake Superior -terminal points for the wheat traffic. Thence it runs west to Winnipeg through wheat-growing regions, then on over the Rockies to Vancouver on the Pacific. The Grand Trunk Railway connects all the cities and nearly all the towns of Eastern Canada. Its summer port is Montreal, and its winter port Portland (Maine). It is now adding to its system a transcontinental line, expected to be completed in 1911, and to be called the Grand Trunk Pacific Railway. From Quebec westward the line will extend through the undeveloped portions of Ontario and Quebec to Winnipeg, then on to Edmonton, and finally to the Pacific Coast at Prince Rupert. From Quebec eastward it will extend to a junction with the Intercolonial at Moncton, New Brunswick. The total length of the line is to be 3,600 miles, and a striking feature is the low gradients-from Winnipeg to Prince Rupert the maximum gradient is 26 feet to the mile, and eastwards it is but 21 feet to the mile. Of the two sections into which the 1,756 miles of the Western division of this great railway is divided, that known as the "Prairie section," from Winnipeg via Edmonton to Wolf Crests, Alberta, and picturesquely described as "Canada's Bread Basket," passes through the great wheat-growing belt of the North-West, four times the area of the whole wheat land of the United States. This new road, owing to costly, skilful, and careful construction, will probably be capable of handling per train four times the tonnage of the average transcontinental railway. Experts have 
calculated that the latest type of locomotive will $b$ capable of moving nearly, if not quite, 100,000 bushels of grain from the prairies to Prince Rupert, from which place it will be conveyed by water through the Panama Canal, or by the Cape Horn, or even the Suez route to Europe, and will provide the most advantageous route for wheat shipments to the Far East. The branch lines of this railway up to Hudson Bay will doubtless in the future relieve wheat congestion.

The Canadian Northern System is, as yet, chiefly in Central Canada. The main line extends from Port Arthur through Winnipeg to Edmonton. It is now building new lines in Saskatchewan and Alberta, which will open up a vast expanse of new wheat lands. It also has lines in Nova Scotia, Quebec, and Ontario, and rapid progress is being made in connecting these sections to make a third transcontinental railway. The Great Northern is a United States railway system, operating in the North-Western States. It has already built some branches, and projected a number of others into Western Canada, and it is expected that it will be further greatly extended in the near future.

The importance of the Hudson Bay Railway from Pas Mission to Fort Churchill, to be built by the Canadian Government, cannot yet be seen in all fulness. It is impossible to foresee now all the factors, advantageous and otherwise, of this route as a wheat route; such factors as immigration into the neighbourhood, climate and soil, and the season of navigation in Hudson Bay and Strait, must be considered; but pressure will be relieved during the height of the crop-exporting season. Not only will this railway shorten the route from the 
Western Provinces to Liverpool by about 1,000 miles, but the saving in freight will amount to something like 7s. per ton. The Government of Canada has shown its readiness to step in where capitalists feared to tread.

The West must always depend largely on her railways, for, even if the waterways were developed, they could only transport a portion of the surplus wheat. After reaching Port Arthur, water transportation is the rule during the season of navigation. The figures for 1910 were : Rail, 6,746,586 bushels ; vessel, 63,125,778 bushels.

The principal railways carrying wheat are the Canadian Pacific, the Canadian Northern, the Grand Trunk, the Midland Railway of Manitoba, the Brandon Saskatchewan and Hudson Bay Railway, and the Alberta Railway. The greatest wheat route of Canada is that which gathers wheat in the North-West, and hauls it to Port Arthur, or other lake port, whence during the open season it moves by water along the St. Lawrence route. The St. Lawrence River and the Great Lakes, supplemented by a number of short canals, form a system of internal navigation unequalled in any other continent., The first canal constructed was the Lachine, immediately above Montreal, and opened in 1825. Other canals between Montreal and Lake Ontario were completed by 1843 . The first Welland Canal (which now runs parallel to the Niagara River, and avoids the Falls of Niagara) was completed in 1829. The present new canal was completed in 1881 ; it is the longest St. Lawrence canal, being twenty-seven miles long. The shortest canal, but a most important one, is the Sault St. Marie ("Soo") Canal, between Lakes Superior and Huron, which was completed in 1895. It is little more than a mile long, but the 
traffic through it is greater than that through the Suez Canal. In 1891 all the St. Lawrence canals, from Port Colborne to Montreal, were completed for 14-feet navigation, and the ship channel below Montreal was made $27 \frac{1}{2}$ feet deep. Manitoba grain came down to Port Arthur, and Canadian vesselmen expected better times on the St. Lawrence; but it was not till 1903 that the St. Lawrence clearly proved itself capable of competing in carrying produce from the head of Lake Superior to the seaboard. Its chief competitors were the Erie Canal and the railways from Buffalo to New York. The main cause of the depression was the slow progress of improvements at Montreal ; there were no storehouses to receive the grain, and vessels had sometimes to wait several days for an ocean steamer to arrive to unload them. In 1908 grain was carried from Fort William to Montreal as low as 3.5 cents per bushel, while the American route, via Buffalo to New York, was 7 cents. The result was that Montreal secured most of the grain exports to England. By the St. Lawrence route ships can traverse a distance of 2,260 miles, from the Straits of Belle Isle to Port Arthur, within 1,915 miles of Vancouver. This great inland system of waterways is, however, unfortunately, only available for a period of about 215 to 230 days in the year. In winter, all the ports are blocked with lake-shore ice, which renders navigation impossible from the end of the first week in December until about the fourth week in April.

The lake vessels in the Canadian trade convey their cargoes to ports on Lake Huron, including Georgian Bay, or they proceed by the St. Clair River to Lake Erie, where they land their wheat at Buffalo; or further, via the 
Welland Canal, to Toronto or Kingston, on Lake Ontario ; or, still farther, via the St. Lawrence River and the Lachine Canal, to Montreal. When the vessels discharge their cargoes at the Lake Huron ports, these cargoes are transferred to elevators, and from thence to cars, by which they are transported to Montreal, Portland (Maine), to Boston (Massachusetts), or to New York. Thence the wheat is shipped to European ports. It is transported "in bond" across the United States to the eastern ports.

A considerable quantity of wheat from the United States ports, chiefly Duluth and Chicago, destined for consumption in the United States or for export, is shipped to Depôt Harbour, Georgian Bay, and is transported by the Canada Atlantic Railway "in bond" through the portion of Canada which intervenes between the Georgian Bay and the border of the United States. When transported " in bond," the grain is subject to no duty, neither when it enters the United States, nor when it re-enters Canada. This method of transportation is resorted to either to take advantage of low freight rates and easy routes or to avoid traffic congestion.

In the winter months, when grain traffic on the Great Lakes is impossible, much Canadian wheat finds its way to the eastern ports of the United States; for there is excellent railway communication to them, and they are in close touch with the European markets. St. John (New Brunswick) is their only serious competitor, and it is surpassed by Boston.

The movement of wheat on the Great Lakes is well seen in the following table (it is to be noted that it does not solely represent Canadian grain destined for Europe) : 


\begin{tabular}{|c|c|c|c|c|c|}
\hline 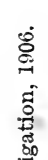 & 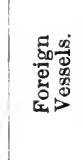 & 照 & 1 & 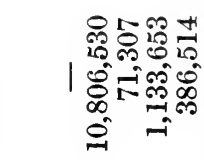 & $\begin{array}{l}\ddot{8} \\
8 \\
0 \\
0 \\
0 \\
\text { o } \\
-1\end{array}$ \\
\hline 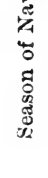 & 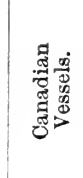 & 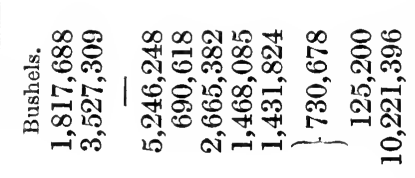 & 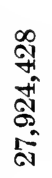 & 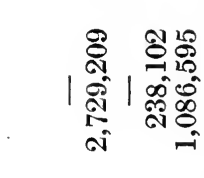 & 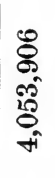 \\
\hline 占 & 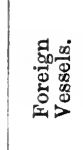 & 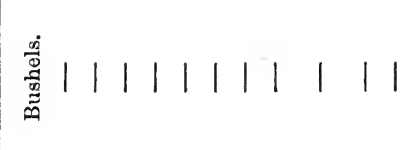 & 1 & 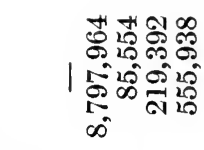 & $\begin{array}{l}\infty \\
\infty \\
\infty \\
\infty \\
0 \\
0 \\
0 \\
0\end{array}$ \\
\hline 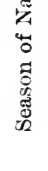 & 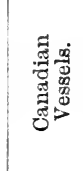 & 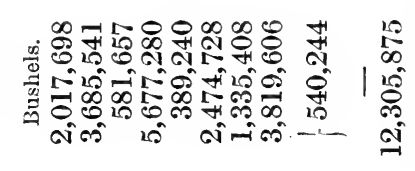 & 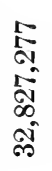 & 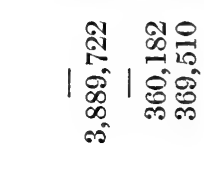 & 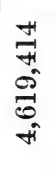 \\
\hline 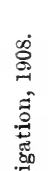 & 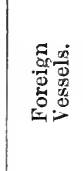 & 递 & 1 & 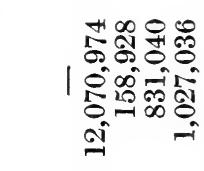 & 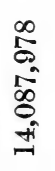 \\
\hline 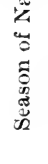 & 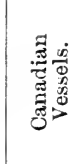 & 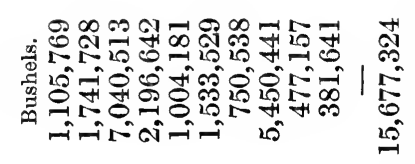 & 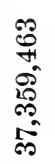 & 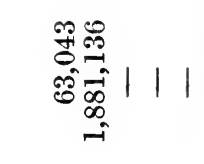 & $\underset{-i}{\stackrel{5}{a}}$ \\
\hline & 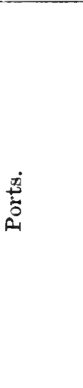 & 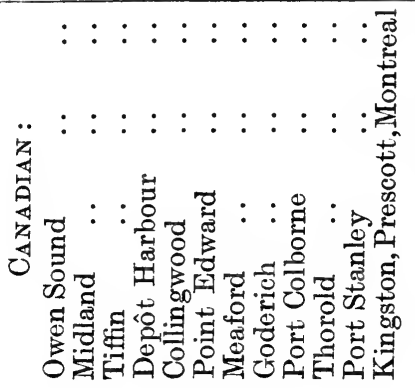 & 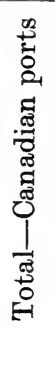 & 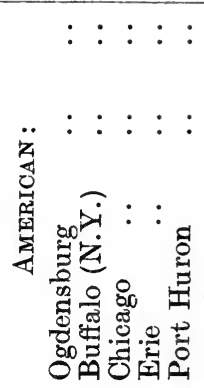 & 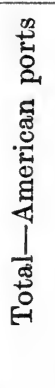 \\
\hline
\end{tabular}


Transportation charges are of vital importance to the wheat-grower, especially in regard to the wheat destined for exportation. The general reduction in freight rates of rail, river, lake, and ocean has been, and is one of the great factors in the international trade in wheat.

Rates by Rail on Wheat from Pornts in Manitoba, Saskatchewan, and Alberta, by the Canadian Padific Railway to Fort William and Port Arthur (1908).

From-

Deloraine (Manitoba) in Cents.

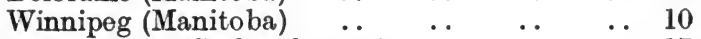

Indian Head (Saskatchewan) .. $\quad \ldots \quad \ldots 17$

Regina (Saskatchewan) $\quad \ldots \quad \ldots \quad \ldots 18$

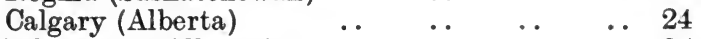

Edmonton (Alberta) $\quad \ldots \quad \ldots \quad \ldots \quad \ldots 25$

From Fort William and Port Arthur, by the Canadian Pacific RAILWAY, TO-

\begin{tabular}{|c|c|c|c|}
\hline & & & Cents. \\
\hline Depôt Harbour (Ontario) & & & .. 20 \\
\hline Toronto (Ontario) & .. & .. & 20 \\
\hline Montreal (Quebec) & • & .. & $\therefore \quad 20$ \\
\hline St. John (New Brunswick) & $\cdots$ & .. & .. 30 \\
\hline Halifax (Nova Scotia) & .. & .. & .. $32 \frac{1}{2}$ \\
\hline
\end{tabular}

(Freight rates from points in Alberta to Vancouver, 13.5 cents per bushel).

Rates on Wheat by Vessel from Fort William and Port Arthur to Georgian Ports, Buffalo, Kingston, Montreal.

Season of Navigation, 1908.

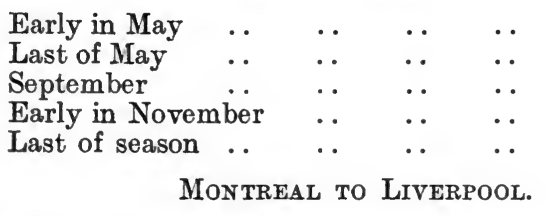

Early in the opening season of navigation

June

September

November

Considering freight rates generally in Canada, it may be said that they compare most favourably with the rest of the continent. 
The railways of Canada are unable to cope with the amount of wheat ready to be conveyed to Fort William and Port Arthur before navigation on the Great Lakes ceases, and much grumbling results on the part of the North-Western wheat farmers. The great extension of railways and the future Hudson Bay route may in time remove the difficulty. The great inland sea, which penetrates into the heart of the Canadian North-West, seems to offer an attractive route for communication with the interior. The great drawback is the navigation of Hudson Strait, and the unreliability of the compass in these regions. The route from Winnipeg via Hudson Bay to Liverpool is actually shorter by nearly 700 miles than the route via Montreal and the Straits of Belle Isle. Canadian authorities are of opinion that the period of safe navigation for freight ships is from early in July until November 10. The distance from Fort Churchill (latitude 58 degrees north) to Liverpool is almost the same as that from Montreal to Liverpool, but the centre of the prairie wheat fields will, when the Hudson Bay Railway is completed, be as near a seaport as it now is to the Great Lakes. Only about 20 per cent. of the total wheat crop can now be exported before Montreal navigation closes, and if this new route will enable steamers to take out one cargo of the previous year's grain (which will be stored in elevators at Churchill), and two cargoes of the new season's crop every year, wheat congestion will be materially relieved.

At the present time navigation ends at the head of Lake Superior, but it has been thought feasible, and may become a possibility in the future, to have the waterway extended to Winnipeg, and possibly to the foot of the Rocky Mountains for a small class of barges, navigating 
the Kaministiquia River, Lake of the Woods, and the numerous small lakes and rivers to Lake Winnipeg. The Red River, with its head-waters in Minnesota, and the Assiniboine empty into Lake Winnipeg, and run thence by way ofthe Nelson River to Hudson Bay; they are many hundred miles in length. The great Saskatchewan also empties into Lake Winnipeg, and runs in two branches to the fertile valley of Saskatchewan, almost to the foot of the Rockies. The waters of these rivers, together with the waters of Lakes Winnipeg, Winnipegosis, Manitoba, and other smaller lakes and rivers, could be carried down to Fort William, and make a continuous waterway from the Rockies to Liverpool-a distance of from 5,000 to 6,000 miles.

The Canadian Government engineer says that it is possible to canalize the waterways from Winnipeg to Hudson Bay, and optimists imagine with satisfaction ocean ships in the future loading grain at Winnipeg for Liverpool via Hudson Bay.

The importance of the Canadian ports as wheat exporters may be ascertained from the following figures :

\begin{tabular}{|c|c|c|c|c|c|}
\hline \multirow{3}{*}{ Montreal* } & & & & \multirow{2}{*}{\multicolumn{2}{|c|}{ Bushels of Wheat }} \\
\hline & & $\cdots$ & $\cdots$ & & \\
\hline & & $\cdots$ & $\cdots$ & .. & $13,564,846$ \\
\hline \multirow{2}{*}{ Quebec } & & $\cdots$ & .. & .. & 一 \\
\hline & 1907 & .. & . & .. & 88,190 \\
\hline \multirow{2}{*}{ St. John (N.B.) } & 19 & $\cdots$ & $\cdots$ & $\cdots$ & $5,845,073$ \\
\hline & & .. & $\cdots$ & .. & $3,126,369$ \\
\hline \multirow{2}{*}{ Halifax } & 1908 & .. & .. & .. & 4 \\
\hline & & .. & $\cdots$ & $\cdots$ & 24 \\
\hline \multirow[t]{2}{*}{ Vancouver } & & - & - & . & $\overline{210}$ \\
\hline & 18 & & . & • & 31,2 \\
\hline
\end{tabular}

* Also exported United States wheat: In 1908, 10,908,194 bushels ; in $1907,5,373,215$ bushels. Vancouver in 1910 exported 1,317 bushels of United States wheat, and 554,237 bushels of Canadian wheat, and Halifax exported 185,006 bushels of Canadian wheat. 
The following United States ports export Canadian wheat, chiefly in the winter months :

$\begin{array}{lcccc} & & & \text { Bushels in 1908. } & \text { Bushels in 1907. } \\ \text { Baltimore } & \ldots & \ldots & 88,432 & \mathbf{3 6 8 , 2 8 5} \\ \text { Boston .. } & . & \ldots & \mathbf{7 , 6 8 7 , 7 4 5} & \mathbf{7 , 7 1 6 , 3 8 9} \\ \text { New York } & . & \ldots & \mathbf{4 , 3 3 3 , 1 1 5} & \mathbf{4 , 0 7 7 , 7 0 5} \\ \text { Philadelphia } & . & \ldots & \mathbf{2 , 4 7 3 , 2 8 4} & \mathbf{2 , 0 7 1 , 7 7 6} \\ \text { Portland (Maine) } & \ldots & \mathbf{5 , 1 8 6 , 1 2 9} & \mathbf{4 , 9 1 5 , 6 6 5}\end{array}$

The importance of the Canadian railways heading for the Pacifio lies not only in the tapping of present and future wheat fields, but also on a possible future trade with the East (Japan and China). The increased development of Pacific steamship lines in recent years is worthy of notice. Prince Rupert is rapidly growing, and its splendid harbour, together with its closer proximity to Yokohama than any other Pacific port, will aid it greatly in wheat exportation to the East. The wheat export from the Pacific is certain to greatly increase in the future.

The needs of Canada, as regards transportation, are more railway lines to convey wheat to ocean or lake ports before navigation closes, and the further development of her waterways; and Canada recognizes these needs. Canada has been, and is very progressive in improving her means of communication, as the following facts show : During a period of sixty years Montreal Harbour has been so improved that it can now accommodate 15,000-ton steamships, whereas, in the early forties of the last century, it could only accommodate 500-ton vessels. Twenty-five years ago the "Soo " Canal had neither telegraph nor railway, and, if a vessel happened to freeze in there for the winter, the crew dared not attempt to get out to civilization. Now there are 


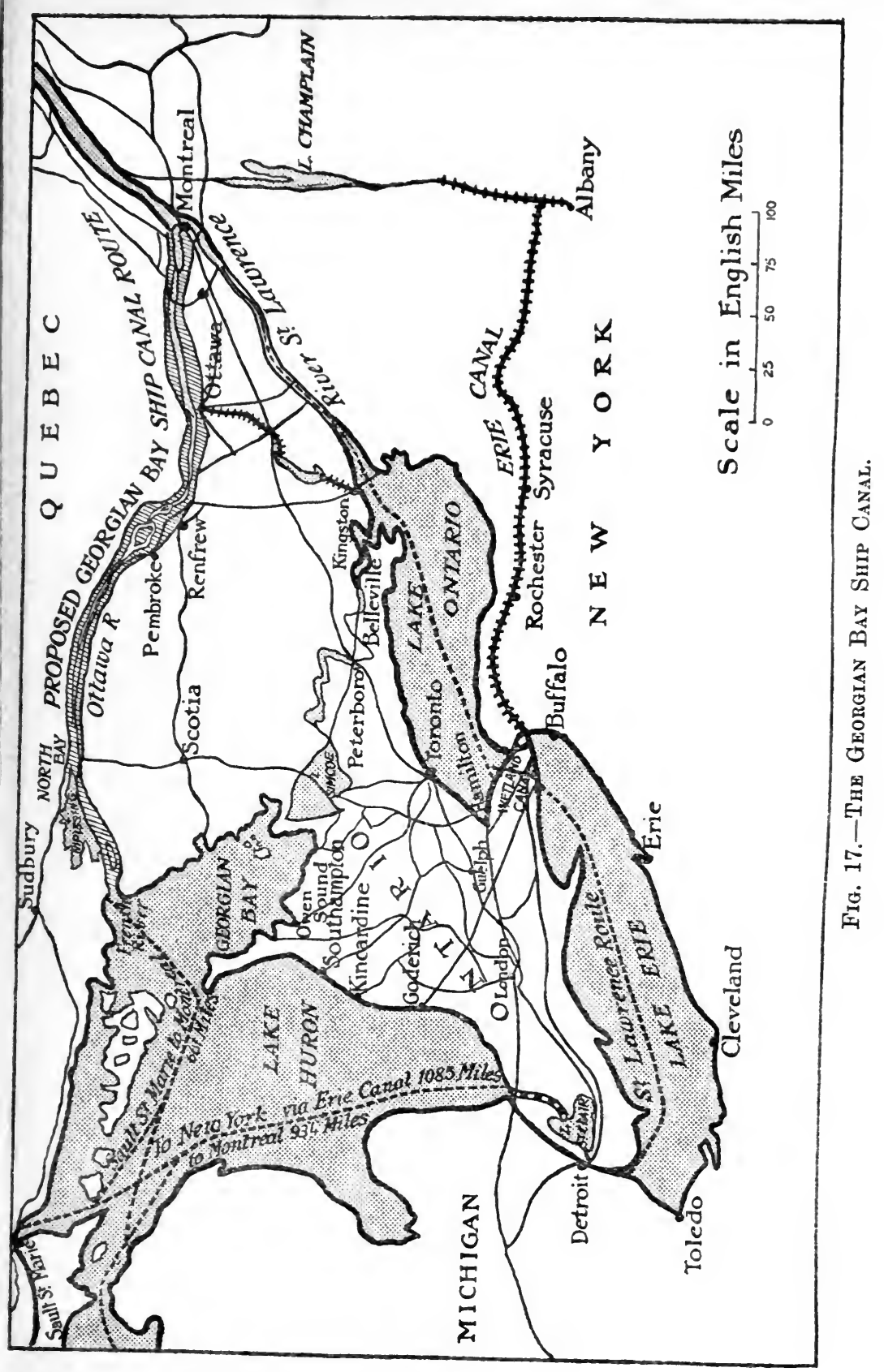


$50,000,000$ tons of freight passing through the canal yearly. The first steamer to load grain at Port Arthur was the Erin, in 1882; to-day, seventy-five Canadian steel ships convey $60,000,000$ bushels of grain yearly to exporting ocean ports. Within a period of about thirty years, Canada has provided herself with a magnificent railway system, which keeps spreading out its arms in all directions, thus opening out the country.

The St. Lawrence route has received much attention of late years, and at the present time efforts are being made to shorten the route from Montreal to Port Arthur by the construction of the Georgian Bay Canal, from the French River, on the Georgian Bay, to Montreal-a distance of about 442 miles. This canal will be essentially a river and lake construction scheme, and will utilize natural waterways, which, fortunately, exist almost in a continuous line from Georgian Bay, on Lake Huron, to Montreal, the most inland and most important of the Canadian ocean ports. The depth of the canal, 22 feet minimum, is such as will accommodate the largest lake steamers in the carrying trade. It is claimed that a 10,000-ton vessel will be able to pass through the 442 miles of the canal in seventy hours. The tendency in regard to lake freighter construction is to increase the length and beam, the draft being limited to 19 or 20 feet.

The principal advantage of this canal in shortening important routes is shown in the table on the following page.

In conclusion, it may with justice be said that Canada's wheat future, so far as it depends on transportation facilities, promises to be bright. 


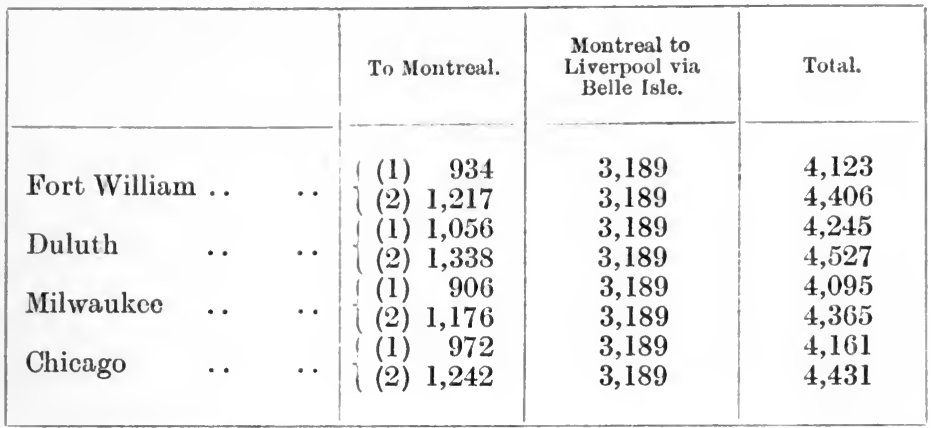

(1) Future new Canadian route via the Great Lakes, Georgian Bay Ship Canal, and Montreal.

(2) Present Canadian route via the Great Lakes, Welland and River St. Lawrence Canals, and Montreal.

\section{The United States.}

The great bulk and value of the internal movement and the exportation of wheat in the United States attach great interest to its transportation facilities.

The grain is conveyed to the local markets in much the same way as in Canada. The primary wheat markets are situated chiefly in the Great Lakes region, and the Middle West. Chicago is the greatest grain market, though surpassed by Minneapolis in wheat receipts, and owes this proud position largely to its excellent communications by lake and rail. Minneapolis is the greatest flour-milling centre; St. Louis is the soft winter and semi-hard winter wheat market, and Kansas the hard winter wheat market.

By 1789 the need of roads was felt in the United States, and one of the earliest and most important highways was the Mohawk and Hudson turnpike, running from Schenactady to Albany. During the early part of the nineteenth 
century, wheat was chiefly transported by the Ohio and Mississippi Rivers to the Gulf ports. The opening of the Erie Canal in 1825 turned wheat transportation eastwards, and the Mississippi grain traffic began to decline. To-day, as a grain carrier, the Mississippi is of small importance; it suffers from the lack of sufficient water in its channel as far north as St. Louis, and the quicker rail transportation has tended to lessen its use. Now, however, there is a movement for the improvement of the inland waterways, including the Ohio, Missouri, Mississippi, and Illinois Rivers, which will probably become a factor in the future carrying of grain. The project of a deep waterway from the Great Lakes to the Gulf of Mexico has been discussed intermittently for half a century, but nothing definite has resulted. A waterway, with a depth of 14 feet, from New Orleans to Chicago, with channels of less depth in the Ohio and Missouri, would solve to a large extent the problem of traffic congestion and high freight rates for a great area of the productive Middle West. It will, if completed, not only aid the wheat exportation to Europe, but the grain trade with the West Indies and Central and South America also.

The United States is very well supplied with railways, and especially in the North Central States. The early railroads were little used for freight traffic, but, by 1870 , they had developed sufficiently to compete with the water routes, and now grain is largely shipped by rail. Much grain was, and a small amount is still, shipped by a part water and part rail route ; but the Erie Canal route has largely fallen into disuse. The Erie Canal, laid through the Mohawk Valley, serves to connect the naviga- 


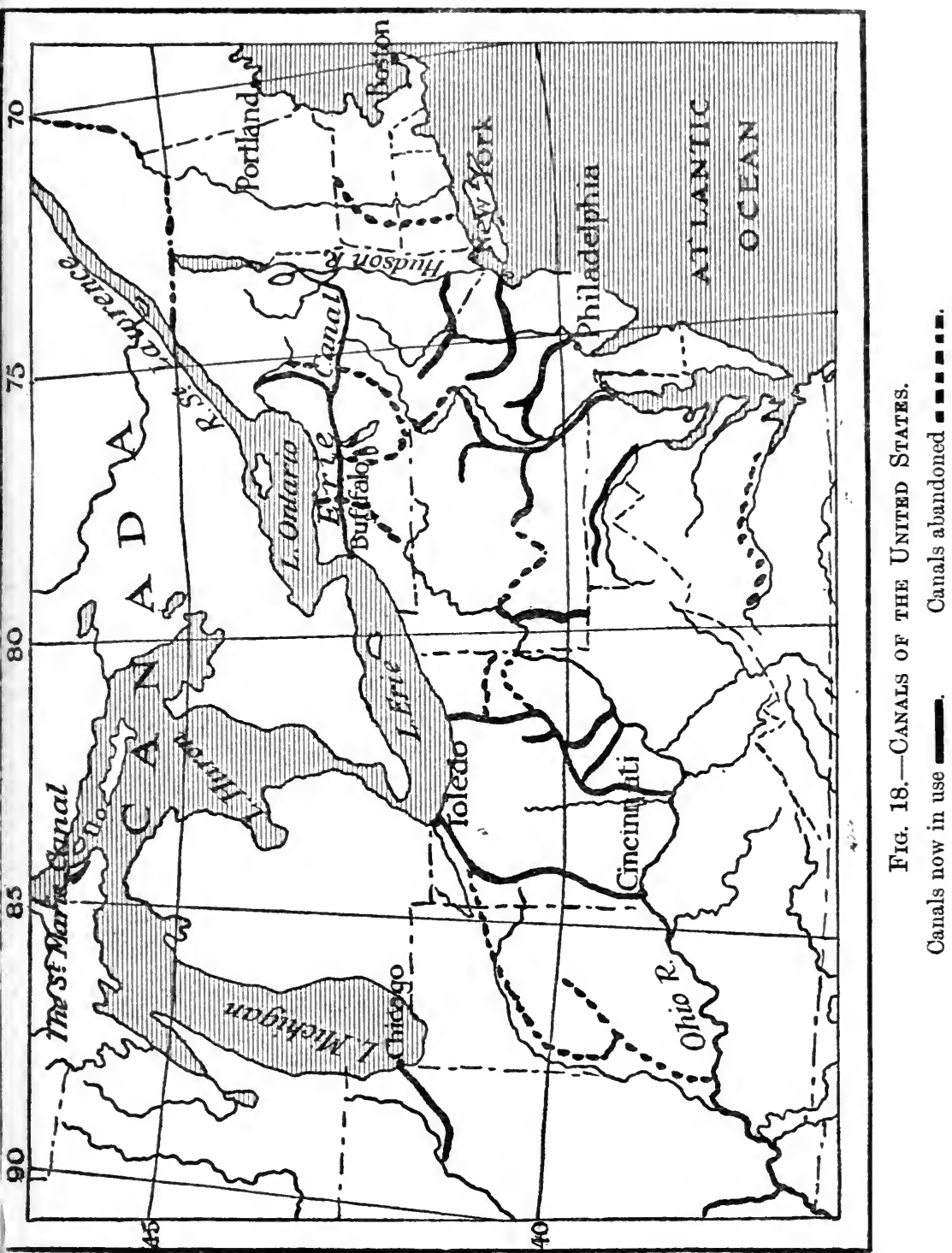


tion of the Great Lakes with New York, starting from Buffalo at the eastern end of Lake Erie, and proceeding eastwards to Troy and Albany, on the Hudson. The Champlain Canal connects the eastern end of the Erie Canal with the head of Lake Champlain, and this completes the waterway between New York and the St. Lawrence. The present Erie Canal is but 6 feet deep, and the canal boats carry only 8,000 bushels of wheat, so that it has been an easy matter for the railways and the Canadian St. Lawrence route to crush it as a wheat transporter. A new Erie Canal is now being made, but only for 1,000-ton boats ; this will doubtless aid the grain traffic, but Canadian competition is bound to injure it, for Canadian canals accommodate 2,400-ton ships. The new canal will follow the line of the present Erie Canal from the Niagara River at Tonawanda to the vicinity of Lyons. From Lyons it will proceed to the south of the Montezuma marshes, into the Seneca and Oneida Rivers, and across Oneida Lake. Thence it will cross to the Mohawk River west of Rome, and then utilize the bed of the river most of the distance to Waterford, on the Hudson.

The United States possesses four transcontinental railways :

1. The Northern Pacific Railway extends from St. Paul and Minneapolis, and from Duluth, to Portland, Oregon, and to Puget Sound.

2. The Great Northern Railway extends from Duluth, and from St. Paul and Minneapolis, to Seattle and Tacoma.

3. The Southern Pacific Railway main line extends 


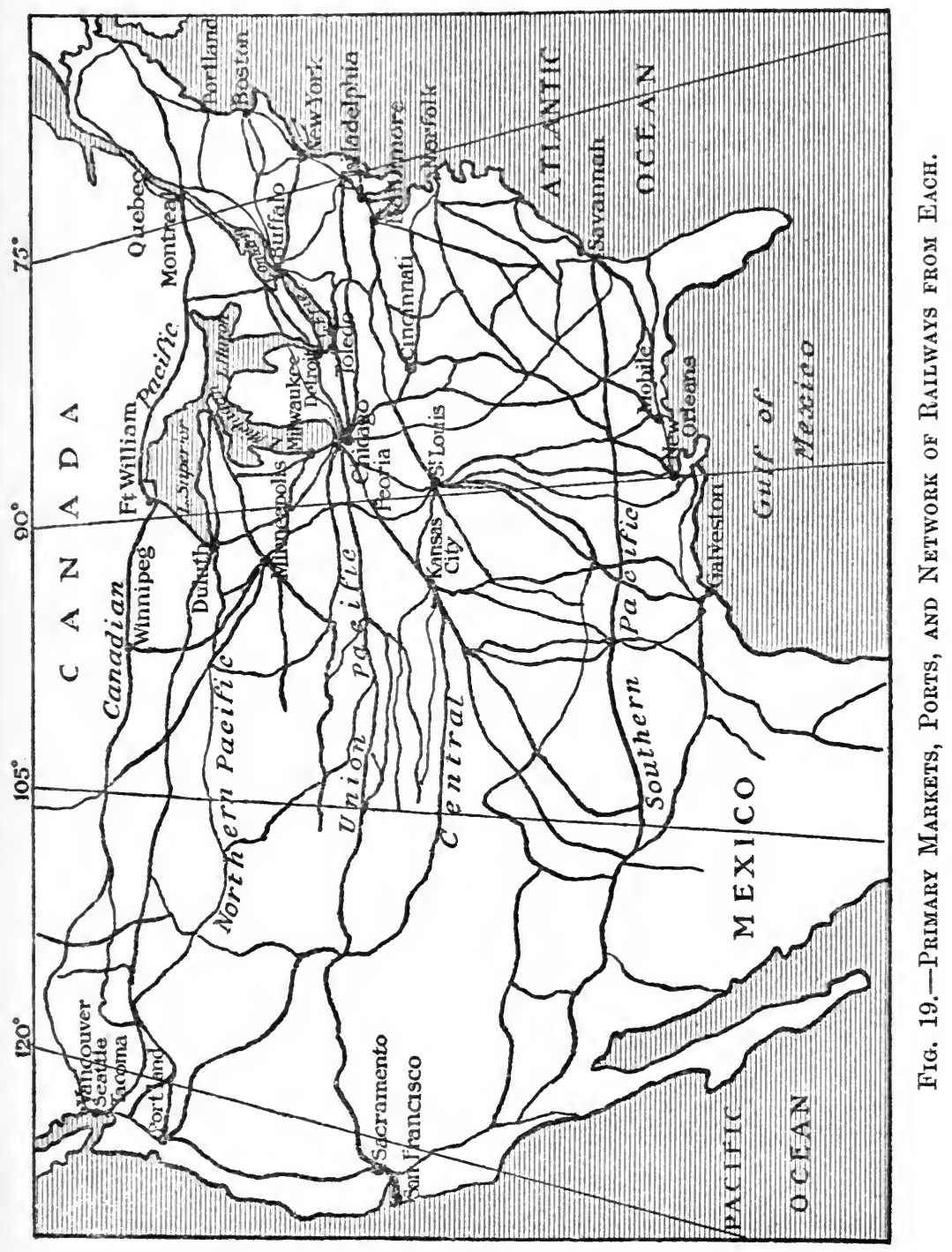


from New Orleans to San Francisco. The Central Pacific Division extends from Ogden (Utah) to San Francisco. At Ogden it connects with the Union Pacific, running to Omaha and Kansas City.

4. The Atchison system extends from Chicago and St. Louis to the Pacific Coast, passing through the SouthWest.

Two additional Pacific lines are under construction :

1. The Western Pacific, from Salt Lake City to San Francisco ; and

2. The Kansas City, Mexico, and Orient, from Kansas City to Topolobampo, near the mouth of the Gulf of California.

The principal eastern rajlways are four in number :

1. The New York Central and Hudson River Railroad connects New York with Albany, and extends through the Mohawk Valley west to Buffalo. Thence, via the Lake Shore and Michigan Southern, it extends to Cleveland, Toledo, and Chicago. It also connects at Buffalo with the Michigan Central, running to Detroit and Chicago.

2. The Pennsylvanian Railroad connects Philadelphia with Chicago, Cincinnati, and St. Louis by way of Pittsburg; and all these cities are connected with New York.

3. The New York, Lake Erie, and Western Railway traverses the southern part of the State of New York, connecting New York with Buffalo, and having a branch to Cincinnati, called the "New York, Pennsylvania, and Ohio."

4. The Baltimore and Ohio Railroad connects Baltimore with Chicago, Cincinnati, St. Louis, and New York. 
The great grain carriers are the Great Northern; Chicago, Milwaukee and St. Paul ; Chicago, Burlington and Quincy; Chicago and North-Western; Northern Pacific; and Atchison, Topeka and Santa Fé. These six roads all operate in the best grain territory. The Northern Pacific and the Great Northern haul some of their grain to Duluth, for lake shipment to Buffalo, and thence south-west to New York; and some of it to Chicago, whence it is distributed both by water and rail. From Duluth to the Atlantic seaboard the railway route for wheat follows the Duluth, South Shore, and Atlantic Railway to Sault St. Marie, and there takes the Canadian Pacific Railway to Montreal, or crosses the border into the United States again, and finds its way to the coast at Portland, Boston, or New York.

In recent years, much grain has been exported from Galveston and New Orleans, as these ports are much nearer to the grain territory in Kansas and Oklahoma than New York is, and are slightly nearer the grain territory in Minnesota, Iowa, Nebraska, and South Dakota, with the advantage of a thoroughfare somewhat less congested than that to the eastern cities. The Santa Fé, the Central, the Gould roads, the Rock Island, and the St. Louis and San Francisco, the Missouri, Kansas and Texas, the Colorado and Southern, and other roads, share in this traffic. Boston, Baltimore, and Philadelphia, and the roads serving them, also obtain some of the traffic, and quarrel in their endeavours to get more.

Distance from primary market to the seaboard, freight rates, and port facilities, are important factors in deter- 
mining the direction taken by export grain. As regards freight rates, the Gulf ports have an advantage over the eastern ports, for the railroads which cross the Alleghany Mountains have heavier gradients than those down the Mississippi Valley, and, consequently, it costs them more to carry grain. Boston and New York, however, have the advantage in freight rates to Europe, and have not that climatic disadvantage possessed by the Gulf ports, whereby "strong" wheats are apt to deteriorate.

The importance of the Great Lakes route may be gauged from the fact that in some months $15,000,000$ bushels of east-bound wheat pass through the "Soo" Canal. The class of lake vessels, known as "whalebacks." is now largely in use ; these vessels are capable of carrying loads of 380,000 bushels. Duluth, on Lake Superior, obtained in 1900 the position of second port of the United States as regards tonnage.

At the great milling centres, such as Minneapolis, much wheat is ground; and owing partly to low freight rates on grain, which are sometimes as low as one cent per bushel, from Chicago or Duluth to Buffalo, a large amount of Western wheat is milled in the Eastern States.

The Pacific Coast wheat trade has distinctive features from the trade east of the Rockies. The wheat is handled in sacks, and the exportation of wheat to Europe is carried on almost entirely by sailing vessels. The question of handling wheat in bulk is now being discussed, and opinion is about equally divided. In the Inland Empire the absence of elevators strikes the easterner at once; in their place he sees warehouses, and even open platforms, where the grain is piled in sacks, and 
protected only by tarpaulins or board roofs. It is to be noted that the development of Oriental commerce and of western transportation facilities, together with the opening of the Panama Canal, will probably have the effect of increasing the wheat exports of the Pacific.

The Panama Canal, which may be completed by 1915 , will have a summit elevation of 85 feet above the sea, to be reached by a flight of three locks, located at Gatun, on the Atlantic side, and one lock at Pedro Miguel, and a flight of two at Miraflores on the Pacific side. The summit level will be maintained by a large dam at Gatun, and a small one at Pedro Miguel, making the great Gatun Lake, which will have an area of 164.23 square miles. A small lake, about 2 square miles in area, with a surface elevation of 55 feet, will be formed on the Pacific side between Pedro Miguel and Miraflores, the valley of the Rio Grande being closed by a small dam and the locks at Miraflores. The canal is to be about 50 miles in length from deep water in the Caribbean Sea to deep water in the Pacific Ocean. The distance from deep water to the shore line in Limon Bay is about $4 \frac{1}{2}$ miles, and from the Pacific shore line to deep water is about 5 miles; hence, the length of the canal from shore to shore will be approximately $40 \frac{1}{2}$ miles. The bottom width of the canal will vary from 200 feet in Culebra Cut to an indefinite width in the deep waters of the lake. The approaches from deep water to land on both sides of the canal are to be 500 feet wide, and the cuts in the shallow parts of the lakes from 500 to 1,000 feet wide. The canal will have a minimum depth of 41 feet. The probabilities are that the opening of the Panama Canal, 
providing the toll charges are not too high, may lead to greater production and exportation of wheat from the Pacific Coast States, North-Western Canada, British Columbia, and Chile. It is improbable that it will affect other wheat regions of America to any great extent. Argentina, Uruguay, and Chile are well able to supply the other South American Republics with all the wheat they may require, unless great crop failure results. Flour is now shipped across the Isthmus of Panama by rail, and reshipped to Port Limon on the Caribbean Sea, for distribution in Costa Rica.

In 1860, California first shipped wheat to England, and though the novel character of the grain was a disadvantage, English millers soon got over the difficulty. Much flour now leaves San Francisco for China, Japan, and the East Indies; about twelve ships per month carry on the trade. The grain, however, still finds its chief market in Great Britain. The Western grain trade may receive a blow in the future, if Manchuria should ever be developed as a wheat-growing country.

About 350 ships are engaged in the grain trade of the Pacific Coast, 65 per cent. of them being English. Regular lines of steamers from San Francisco, Portland, Tacoma, and Seattle carry the flour shipped, but freight rates demand that the grain shall be carried in sailingvessels. In California ships are often loaded directly from the car, but in Oregon and Washington the wheat is more generally re-cleaned, and then resacked before it is loaded.

The wheat belt of Eastern Washington and Northern Idaho has, since 1907, seen a new development in the 
transportation of wheat to the coast. Before 1907, the wheat was conveyed to the coast by steam trains, but early in that year the Spokane and Inland Electric Railway began to operate in the Palouse country, and to compete with the steam railways for a share in the grain business.

The improving of the navigation of the Columbia and Snake Rivers is of great importance to the Inland Empire. When boats and barges are able to sail from Kettle Falls, on the Columbia, and Lewiston, on the Snake, to Portland, freight rates on grain will undoubtedly be materially reduced. For miles these rivers flow through deep cañons, and at several points the grain has to be lowered to boat landings from elevations of 1,000 to 2,000 feet by means of aerial tramways, at a cost of $1 \frac{1}{2}$ to 3 cents per bushel.

The following figures of wheat receipts at primary markets and seaports give some idea of the relative importance of the various centres :

Wheat and Flour Regeipts at the Primary Markets in 1908. ( 1 barrel $=4 \frac{1}{2}$ bushels.)

\begin{tabular}{|c|c|c|c|c|}
\hline & & & Bushels. & Barrels. \\
\hline Chicago & & & $21,168,442$ & $9,496,037$ \\
\hline St. Louis & .. & .. & $19,087,395$ & $2,763,700$ \\
\hline Minneapolis & .. & .. & .. $91,739,900$ & 242,183 \\
\hline Perria & & $\ldots$ & $1,441,238$ & $1,063,100$ \\
\hline Kansas City & & $\ddot{. .}$ & $40,131,309$ & 160,250 \\
\hline Milwaukee & . & .. & $12,995,269$ & $2,678,570$ \\
\hline Toledo. & $\quad .$. & .. & $4,457,200$ & \\
\hline Duluth and & Superior & $\ldots$ & $53,890,816$ & $3,995,200$ \\
\hline Cincinnati & 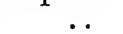 & .. & $4,963,264$ & -* \\
\hline Detroit & .. & .. & $2,433,736$ & 249,100 \\
\hline Omaha & .. & .. & $14,962,800$ & - * \\
\hline
\end{tabular}

* Indicates statistics not available. 
Wheat Receipts at the Ports, 1908.

New York

Buffalo (Lake Port)

Baltimore

Philadelphia

Boston

Newport News

Portland (for six months)

New Orleans

Galveston

San Francisco

Tacoma ..
Bushels.

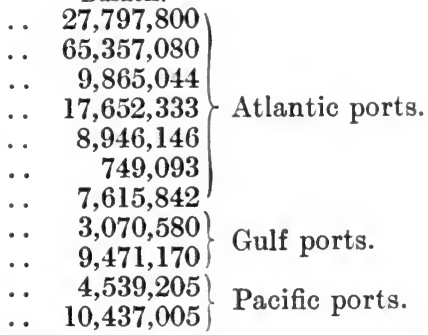

It is well known that goods whose value is high in proportion to their weight are likely to be charged higher freight rates than goods of relatively low value. Value, however, is not the only condition affecting freight charges; under some circumstances, a higher rate may be charged for a less valuable than for a more valuable commodity between the same points. The influence of value and weight upon the cost of carrying is well illustrated in the case of cotton and wheat in the United States; and it is of no little interest to note that this rule of freight traffic applies to the cost incurred by farmers in hauling their products from farms to shipping points. It is estimated that it costs, on an average, 16 cents per 100 pounds to haul cotton from farms to shipping points, while the cost for wheat is 9 cents. The average distance of cotton farms from local shipping points is 11.8 miles, and that for wheat 9.4 miles. The average railway freight rate for cotton from local shipping points to seaports is estimated at 40 cents per 100 pounds, while the corresponding rate for wheat is about 20 cents. This difference in railway charges between these two commodities illustrates the tendency of value to influence 
transportation charges, and also shows one of the several phases of the principle of railway rate making, which is often described as "charging what the traffic will bear." On the ocean, also, freight charges for cotton are higher than those for wheat.

The cost of hauling wheat from farms to local shipping points in the North Central states is 8 cents per 100 pounds; but in Kansas, Ohio, Indiana, and Michigan, the rate is 6 cents; and farmers in Illinois, Wisconsin, Minnesota, Iowa, and Nebraska do this hauling at an average cost of 7 cents per 100 pounds. In Missouri, the mean cost is 9 cents per 100 pounds ; in North Dakota, 10 cents per 100 pounds ; and in South Dakota, 11 cents per 100 pounds. West of the Rocky Mountains, the average cost is 10 cents per 100 pounds, the relatively high rate being largely due to the long distances over which the grain is moved. The mean of the railway freight rates on wheat from local stations in Illinois and Nebraska to Chicago is 16 cents per 100 pounds; and the mean rate to Minneapolis from local stations in Minnesota, North Dakota, South Dakota, and Nebraska is the same. Making allowances for the relative quantities of wheat received at Chicago, Minneapolis, and Kansas City, the average rate on wheat from local shipping points to primary markets is 15.5 cents per 100 pounds, which, added to waggon haulage charges, makes the cost of transportation 24.5 cents per 100 pounds, or $14 \cdot 7$ cents per bushel.

The freight charge from Chicago to New York or Boston for wheat intended for export is about 15 cents per 100 pounds by all-rail routes. Boats on the Great 
Lakes carry wheat from Chicago to Buffalo at rates ranging from 1.25 to 3 cents per bushel; and the railway charge from Buffalo to New York is 4.5 cents per bushel on wheat intended for export. Shipments by way of the Great Lakes and the Erie Canal are sent at still lower rates.

The mean of freight charges to Tacoma, Seattle, and Portland from local stations is 10.2 cents per bushel, which, added to the ocean rate, makes the total transportation cost from these local points to Liverpool 27 cents per bushel.

The cost of transportation from the Atlantic ports to Europe is from 4 to 5 cents per bushel, and from the Gulf ports, 7 to 8 cents. Judging from the changes during the past few generations, it is natural to expect that costs of freight on land and water will be lower in the future. Improved methods of loading and unloading freight, economies in the disposition of cars and vessels, so as to avoid more than at present the hauling of empty cars, and the making of voyages in ballast, all tend to lower the cost of transporting farm products.

\section{Argentina.}

To understand Argentina, the country which has afforded so many surprises in recent years, it should not be assumed that what is fitting in North America may be successfully adopted in Argentina. Her importance as a wheat-grower lies in the fact that most of her wheat must find a foreign market. In good years as much as 70 per cent. is exported. It follows that Argentine wheat must largely find its way to the ports. 
The distance of the present wheat farms to deep water is short; much of the grain is grown within 100 miles of the ports, and little wheat at present is raised at more than four times that distance. The greatest distance is about 500 miles.

The absence of navigable rivers in Argentina, with the exception of the treacherous Paraná, and the Uruguay, have rendered imperative an enormous network of railways over the central provinces, and great development has recently been seen. The lines of the Central Argentine, the Western of Buenos Aires, the Santa Fé, the Buenos Aires and Rosario, and the Entre Rios Railways, with numerous less important lines, traverse the wheat fields of the western and northern districts; while the Great Southern Railway covers the southern district, and is the most extensive railway in Argentina. The railroad systems are chiefly of English construction and ownership. Each company has devoted its energy and capital to the extension of its lines towards the most distant points attainable. The lines, in most cases, do not yet reach the frontiers. Pioneer lines are precarious enterprises, but, in nearly every case in Argentina, it has been a question of a few years only, and then the long straight track without apparent objective has become fully justified. A study of the railroad map shows that the railway companies have left the filling up of the network of cross lines to be dealt with at a later period. Most of the existing lines, as well as those authorized, are more or less parallel to one another, and do not, as a rule, provide for much cross-country traffic. The making of a railroad often precedes the effective location of a town- 




Fig. 21.-Railways and Ports of Argentina. 
ship in the agricultural regions. Stations are generally planned where there is convenient access to water, and with some regard to existing roads, if such they can be called. There are only a few lines on which there is any opportunity for or advantage in the very long train, since the agricultural districts centre round the various ports.

The railroad has to create the traffic, as well as to carry it when established. Little cultivation can be successfully carried on before the advent of a railway, because of want of access to a market; while the change, which results a year or two after the construction of the lines, is astonishing.

The National Government has enacted a law of great import-viz., that every railroad company in the Republic is at liberty to compound for exemption from taxation, and from duties on the importation of materials until 1947. The consideration to be paid is 3 per cent. of the net receipts. The payments are to be applied by the Government in the construction or maintenance of the roads crossed by the railroad, especially of the bridges on these means of communication. If the roads are made more effective for traffic at all seasons, haulage to the stations will be much easier, and new areas for cultivation will be opened up. The straight tracks and level country are factors in the cheap haulage of grain.

The importance of the various railway lines as wheat carriers may be gauged from the table on the opposite page.

The primitive method of transport in Argentina was by means of the waterways, and many years passed without any extension of large settlements to a distance 
from the natural system of navigable rivers. Nearly all the great ports for shipments of wheat to foreign countries are situated on the "rivers" - that is, on the River Plate and its tributaries. The River Plate is something like 100 miles wide at its mouth, and is formed by the confluence of two streams, the Paraná and the Uruguay, which come together not far above the city of Buenos Aires. The Paraná, which forms the eastern border-line of the great wheat-growing province of Santa Fé, is navigable for large steamers as far up as Rosario, and

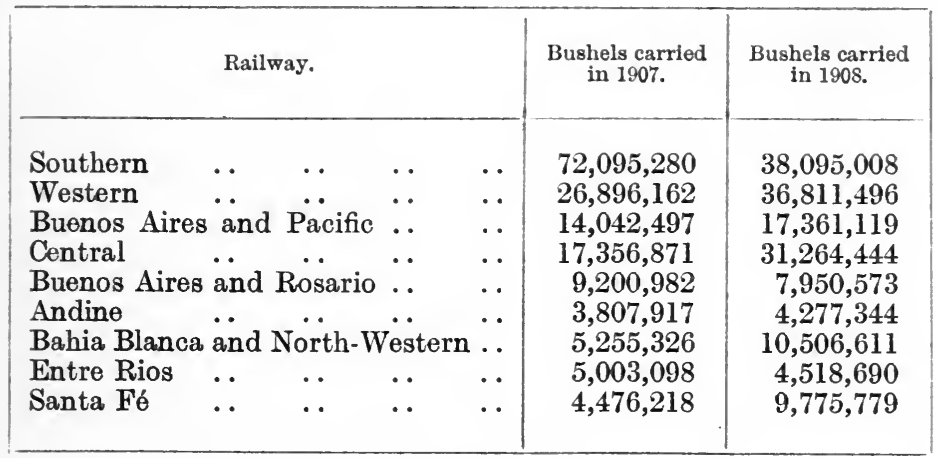

for sailing-vessels for some distance farther up. Rosario is about 190 miles north of Buenos Aires, while Colastiné, the port of the city of Santa Fé, is over 200 miles farther inland. Thus for 400 miles inland, the Plate and the Paraná are navigable for large vessels, and the Argentine wheat fields are practically on or near to the seaboard. The greatest ports for the shipment of Argentine wheat are Bahia Blanca, Buenos Aires, and Rosario; while some quantity of grain is also loaded at La Plata, Colastiné, and San Nicolas. Smaller places are Villa 
Constitucion, Baradero, and Zarate. Bahia Blanca is almost sure to become the most important port; it is well served by the Southern and the Pacific Railroads. The outlay on elevators and other machinery at Bahia Blanca has been very large. So rapid has been the increase in grain exportation here that even now the facilities are not equal to the task of dealing with the traffic at the high speed demanded. The probabilities are that a system of radiating lines from Bahia Blanca to its naturally dependent territories will be seen in the future. La Plata, situated almost at the point where the fresh river water mingles with the ocean, has large deep dock accommodation, but the completion of the docks at Buenos Aires has resulted in Buenos Aires taking much of its trade. The railroad lines here are the Southern and Western, both of which use the Government wharves. The nearness of La Plata to the open ocean enables shipowners to complete their cargoes, and a considerable number of vessels from Rosario and San Nicolas find it suitable for their requirements; but La Plata, although it has received every encouragement, has never flourished much as a port. Buenos Aires and Rosario are providing excellent facilities for dealing with wheat, and are well served by the railways. Paraná and Corrientes may be described as feeding-ports for the main wheat ports. The "embarcaderos" at San Nicolas, Baradero, and Zarate are located among the side channels, but all have sufficient water for ocean-going craft. The little quays, where schooners and barges can load cargoes of wheat, are very numerous, and serve as supply points for the great ports. 
The changes in the depth of water are frequent on the rivers and the estuary, but they are the subject of careful study by the authorities, especially the depth of the water between Rosario and the roadstead outside Buenos Aires.

The following were the exports of wheat from the various ports in 1908 :

\begin{tabular}{|c|c|c|c|c|}
\hline 3 sarin & & & & Bushels. \\
\hline Bahia Blanca & . & .. & & $37,919,537$ \\
\hline Buenos Aires & .. & .. & & $34,673,742$ \\
\hline Plata & .. & .. & .. & $12,974,988$ \\
\hline Santa Fé & . & .. & & $9,197,087$ \\
\hline an Nicolas & .. & .. & $\cdots$ & 986,432 \\
\hline illa Constituc & cion & .. & & 229,037 \\
\hline her & & & & 4,130 \\
\hline
\end{tabular}

Though many of the Argentine railways were built mainly for wheat transportation, it is surprising that few conveniences are provided at the stations for unloading the waggons, or loading the grain on cars. Till recently, few warehouses were available for the small farmer, and, even where they were provided, the Italian farmer would rarely pay the charge demanded for storing the grain. He preferred to pile it out of doors, where, being exposed to the weather, it naturally deteriorated. Grain buyers did, however, sometimes cover their piles of sacks with canvas. There are signs of improvement now at the stations, for the railway companies are now compelled to provide free storage for all grain for shipment. Lack of care of the grain is, nevertheless, still noticeable at the farm and at the seaport.

When the wheat harvest proves very good, it often happens that, in spite of Government orders, the rolling stock is quite inadequate for the traffic, and the result 
is that, with the accumulation of work in the docks, a crop is sometimes kept locally for a whole year, before it can be removed to a port. The type of car in use is the old English, which has a capacity of from 10 to 18 tons, but the principal railways are now getting American cars, having a capacity of from 30 to 40 tons. Transportation of the wheat to the seaports is almost exclusively by rail, the freight rates varying from 5 to 15 cents per bushel, depending largely on distance. The hauling charges from farms to local stations vary from $7 \cdot 8$ to 11.7 cents per bushel for distances above twenty miles.

Shipping facilities at the seaports are growing rapidly, but they are still very inadequate. The river ports suffer from the tremendous amount of silt brought down by the Paraná, and constant dredging is necessary. Doubtless, in the future a great port will be made at Mar del Plata, where the only rock foundation on the whole coast is to be found. The ships at the ports are frequently kept waiting for days before being loaded. Sometimes they are berthed three deep, so that the bags of wheat have to be carried one at a time by men from the railway cars on the track alongside across two ships into the hold of another. Tramp ships of 2,500 tons to 6,000 tons register usually do the ocean transportation, and, having always to make room for steamers, it is easy to see that to get 300 or 400 car-loads into their hold must take some days. The freight rate to Europe is from 6 to 12 cents per bushel, depending largely on the season, and facilities for return cargo.

The growth of Argentine shipping facilities for wheat since 1903 has been astonishing ; large elevators have been 
built at the ports, and much money has been spent on dredging and other harbour improvements. Bahia Blanca is an excellent example; the port is controlled by two railroad companies, which have built elevators, and made many other improvements to facilitate grain handling. These undertakings are wise measures, for wheat-growing is increasing in that direction. The Entre Rios line has also improved the port at Ibicuy, and increased the facilities for grain handling.

New railways are being constructed in practically every part of the wheat districts of Argentina, and, in fact, no other South American Republic can show as much progress in railroad construction.

It is evident from a study of the foregoing details that the Argentine wheat farmer loses a good profit through the lack of proper facilities and improved methods in getting his product to market, after it has been threshed. The cost of the bags he uses, bad roads, absence of elevators, shortage of railway cars, local taxes on production, high freight rates, and inadequate facilities in the shipping ports, increase charges, and reduce the price paid to the farmer for his wheat.

Much has yet, then, to be done by Argentina in improving her roads, her railway facilities, and the facilities at her ports. It is evident, however, that the Government and private individuals are well aware of the importance of transportation facilities, and they must pay attention to a matter of such vital importance to the country. The efforts now being made may, perhaps, be taken as a good omen for the future.

Of the remaining countries of America, little need be 
said, for only two-Chile and Uruguay-export wheat; and even these two countries export only a small amount. Uruguay's wheat for export goes to Brazil and Western Europe. Monte Video is its chief port. The facilities for transportation in Chile are not of the best ; she needs more railways, better ports, better shipping facilities, and better storage facilities for her grain. Her chief markets are the South American Republics to the north of her and Great Britain. Peru takes a large amount of her export wheat, sometimes practically two-thirds of the amount exported; and Great Britain takes over a quarter. 


\section{CHAPTER VIII}

\section{STORAGE OF WHEAT *}

LIKE the transportation, the storage of wheat has four main aspects : (1) Storage at the farm; (2) at the local market; (3) at the primary market; and (4) at the seaboard.

\section{Storage of Wheat at the Farm.}

In Canada and the United States, granaries are a necessity on those farms where distance from the railways necessitates storage of the grain for at least part of the year, or where the farmer prefers to hold his grain for a better market. Few farmers in Argentina will incur the expense of constructing sheds for storing purposes. The method is to take all risks, and sell the grain, which is delivered at the railway-station, as soon as threshed. On the Pacific Coast of the United States, storage is not considered of importance; the sacked grain is left lying in the open field, until it is shipped. There is no very great risk, for rains seldom fall during the heavy shipping season. On the "bonanza" farms of the Dakotas, the grain is stored in elevators of about 50,000 bushels capacity, situated by the side of the railway track at

* The author is indebted for some facts regarding storage in the United States to Dondlinger's excellent work, "The Book of Wheat." 
opposite corners of the farms. Where mixed farming is carried on, as in Eastern Canada and the Eastern United States, there is usually sufficient granary room on the farm to store the wheat held over.

\section{Storage of Wheat at the Local Market.}

The growth of agricultural territory in the United States and Canada, following upon pioneer railway building, caused a new development in the handling of crops. Before railroads spread their network over the vast wheat regions, the storage of wheat in small elevators along the lines of road in operation was little in vogue; only the primary markets had economic facilities for the proper handling of the cereals. With the rapid extension of acreage, however, came the demand for handling facilities, and railway companies and private individuals established store-houses on the lines to shelter safely, and transfer economically the wheat for transmission. Development in North-West Canada came later than in the United States. When the Canadian North-West was being opened up in the early days (1884-1890), a number of so-called "flat warehouses" were built by private persons at different points on the Canadian Pacific Railway. The small business that could be done, and the few economies that could be practised, together with the establishment of the elevator system in the Dakotas and Minnesota, resulted in the Canadian Pacific Railway encouraging the formation of elevator companies, and the building of elevators at their stations. Now elevators are among the principal objects at the prairie stations.

While much may be said against the elevator system 
and management, yet the gist of the matter seems to be that it is the most convenient and rapid method of handling grain yet devised. Without the aid of elevators a vast army of men would have to be employed, and the operations would be so slow and expensive that wheat production would have to be curtailed. The elevator at the local market often has machinery capable of emptying 10,000 bushels an hour from waggons.

Cars at the local markets are filled for the primary markets in the following manner: Boards are placed across the doorway of each car, forming a barrier as high as the grain is to be loaded inside. The cars are hauled alongside the elevator, and spouts put through the doors above the tops of the boards; then the grain, supplied from the bins, runs out either by gravitational force or by means of belt conveyors.

The successful working of elevators is dependent on the flowing quality of grain, but at present the Pacific Coast States are lacking in elevators. The grain is handled in sacks, and since its destination is in most cases the port of shipment, the facilities are such that trains can be run from the wheat fields to tide-water at a very few hours' notice, and a large saving in the handling and warehouse requirements is made by loading ships directly from the cars. Wheat not shipped at once is either heaped up in huge piles out of doors, or sometimes in warehouses at the shipping points. These warehouses, operated by farmers' unions or grain-buying firms, vary in size from 40 feet by 90 feet to 50 feet by 200 feet, and their capacity is from 36,000 to 48,000 sacks. In Washington and Oregon, wheat reaching shipping points is, however, run 
through a grain warehouse, where it is cleaned and graded, after which it is re-sacked, and loaded on the vessels or cars for final shipment. The question of handling wheat in bulk has been agitated in the Pacific States, with opinion about equally divided.

The elevators at the local markets are owned either by the farmers themselves, by the local grain dealers, or by the grain buyers situated at the primary markets. Line elevator companies, composed of grain buyers at the primary markets, own hundreds of elevators at the railway stations in the grain territories.

According to the Industrial Commission Report of the United States there were in 1901 in Brown County, South Dakota, 45 elevators with a capacity of from 12,000 to 15,000 bushels each, 12 " flat warehouses " with a capacity of from 3,000 to 5,000 bushels each, and 3 large elevators belonging to flour-mills, besides 30 warehouses belonging to 12 line companies. This county, which is 36 miles wide by 48 miles long, may be taken as a typical example of storage conditions in the commercial wheat regions of North America.

In Argentina, storage conditions are more primitive than in North America. It is very seldom that grain can be loaded into the railway-cars directly from the carts, that haul it from the "chacra" or farm. In some of the principal wheat stations, corrugated iron warehouses have been built for the storage of grain, but these are principally for the use of wheat buyers, or owners of large tracts of rented land. Wheat is stored in them to be held for a better price, or to await the supply of cars. Governmental action in compelling free storage of grain for ship- 
ment will help the small farmer, but, at present, the storage facilities at the station are very inadequate. Even yet, wheat is stacked in great piles of bags in the country stations awaiting shipment. It is almost invariably sold to some regular buyer for cash on arrival in the station, or before, and the responsibility for its care is thereafter with the buyer. These buyers usually have immense heavy canvas covers to put over the piles, which are built on platforms 6 inches from the ground, and, if well covered, suffer little damage.

It does not seem easy to suggest any practicable method of storage at the country stations in Argentina beside piling the wheat in bags under cover of sheds or warehouses, which should be of the simplest construction, allowing for a number of country carts to be unloaded at the same time. It is possible that an arrangement might be made for loading from the shed into bulk trucks, and the quality might then be determined, much as it is graded in North America by the elevator companies, after it reaches the depôt. It must be remembered that in Argentina the Italian or Spaniard, who grows the grain, is, in many respects, little more than an agricultural labourer. He brings his produce to the station in small quantities, and has to do the best he can in selling it, being quite unable to provide the buyer with any uniform quality, or other exact details as to what there is to be dealt with. Differences in quality and cleanness result from the carelessness and indifference of the farmer, and such differences are very troublesome when the question of dealing with grain on a uniform basis as in North America has to be considered. 
Elevators have been mentioned as a method of overcoming the storage difficulty at the railway-stations, and the advocates for them are many at the interior stations. As yet, however, no plan has been suggested which does not involve a large original outlay, very large, at least, in comparison with the possible receipts, when all the year round is considered. Unless it occurred to some large trader to monopolize the elevator for some three or four months by filling it up completely, there would probably be a good turnover for the first part of the year, but afterwards the elevator would be nearly useless in most seasons. There are, doubtless, important localities which would provide work for the machinery and staff, sufficient to pay expenses all the year round, but these are few, and the rate of interest on capital outlay is a high one in Argentina.

Where elevators are lacking, wheat is often transferred directly from the waggon to the car by means of manual labour. In the Canadian North-West, the railway companies provide "sidings" or tracks, and build platforms at country points, which enable the farmers to haul their loads up to the car door, and shovel the grain into the car. The grain is then shipped to some commission house. The labour of peons in unloading the waggons and loading the cars at local stations in Argentina costs eight cents per bushel, but the farmer sometimes avoids this charge by doing the work himself. There is nearly always a "truck famine" in Argentina at the busy times; and, to add to the inconvenience of the trade, the condition of the grain has to be closely watched, when it is accepted from the farmer in all but the very dry seasons. The railroad officials will not issue any binding acknowledgment of the 
receipt of the grain, until they have trucks ready to receive the goods. The buyer is then prepared to have the weight and quality tested, and to exercise his rights as to rejecting inferior grades. These operations are usually performed on a " planchada" or platform, usually erected for the occasion, and are interrupted in wet weather. It is easy to see that the agent of a large exporter, who can afford to provide storage, and can provide loads for every truck as it comes to hand, can virtually exclude other traders at the times of greatest pressure.

The elevator system in North-West Canada is rapidly increasing. In the three provinces of Manitoba, Saskatchewan, and Alberta (including six for British Columbia), there were in 19101,867 elevators and elevator warehouses. One (at St. Boniface) had a capacity of 500,000 bushels, and three had a capacity of 250,000 bushels each. Four had capacities of 400,000, 300,000, 250,000 , and 235,000 bushels respectively; two had capacities of 200,000 bushels each ; one had a capacity of 160,000 bushels; and two others had capacities of 150,000 bushels each. The average capacity is about 29,000 bushels.

3. Storage of Wheat at the Primary Market.

The capacity of the elevators at the primary markets to handle and store grain is enormous. Often, to increase the storage capacity, large tanks capable of holding 60,000 to 80,000 bushels or more are built, and placed alongside the main elevator. They are filled from the top by a belt conveyor, and emptied from the bottom by a similar arrangement. Chicago's first elevators were built in 
the fifties of the last century, and on January 1, 1909, the total capacity of the grain elevators in that city was 54,245,000 bushels; one of these elevators, together with its annexes, has a storage capacity of 5,000,000 bushels. Minneapolis, the greatest flour-milling and wheat-receiving centre, had a storage capacity of $42,240,000$ bushels. St. Louis and East St. Louis had a combined capacity of $12,000,000$ bushels. Kansas City had a capacity of $15,000,000$ bushels, and DuluthSuperior $30,000,000$ bushels. There were fifteen elevators classed as terminals in Canada in 1910. At Port Arthur, Ontario, the Canadian Northern Railway owned two, with a capacity of $3,750,000$ and $3,250,000$ bushels respectively. These were operated by the Port Arthur Elevator Company. At Port Arthur also an elevator of 750,000 bushels capacity was operated by D. Horn and Company. The Canadian Pacific Railway at Fort William operated three elevators, with a respective capacity of $2,737,500$, $2,458,000$, and 2,234,000 bushels each. The Empire Elevator Company had one of 1,750,000 bushels' capacity; the Consolidated one of $1,750,000$ bushels; the Ogilvie Flour Mills Company one of 1,100,000 bushels ; and Muirhead, Black, and Company one of 125,000 bushels' capacity. At Keewatin, Ontario, the Lake of the Woods Milling Company had two milling elevators, with a capacity of 750,000 and 550,000 bushels respectively. At Kenora, Ontario, the Maple Leaf Flour Mills Company had one of 400,000 bushels' capacity. The greater portion of the grain taken into the hundreds of smaller elevators in the west, and shipped from loading platforms at country points, finds its way into the lake terminals, and is shipped 
from thence by vessel to the Georgian Bay ports, Lake Huron ports, Montreal, Kingston, and Prescott. In addition, a quantity of grain is shipped direct by rail over the Great Northern Railway to Duluth, and is afterwards transferred "in bond" over the United States territory to Buffalo and Montreal for shipment abroad.

Elevators at the terminal points are owned by private individuals and companies. The centralizing and consolidation of railway systems brought with them the consolidation of elevator companies. The local storehouses came under the control of the interests operating the terminal plants. Where the railways owned their own storehouses, they found it impracticable to operate them themselves, and made operating agreements with, or sales to, companies or individuals, who would do this work. These companies became the medium through which practically all cereals tributary to the respective lines of road on which they operated must go to market. The laws of some states prohibit a public warehouseman from trading in grain, so other companies have been organized, working in conjunction with warehousemen to handle the business. The shipping and receiving of wheat has therefore, in the United States, passed into a few hands.

Cars are unloaded at the terminal elevators by means of large scoops pulled by machinery, but placed in position and guided by hand. It is a common practice for the grain to be received from the car through a grating into a pit, at the bottom of which are belt conveyors. From the pit the grain is carried to the top of the elevator, where it is weighed on large scales, capable 
sometimes of holding 500 bushels each. After being weighed, the grain is transferred to the bins below, from which it may again be conveyed by the force of gravity, or by moving belts, to other parts of the elevator or to the chutes, which deliver it to cars or vessels. It should be noted that elevators are also used to clean grain and to mix different grades of the same kind of wheat.

Buffalo, though not a primary market in the usual sense, is yet a great receiving centre for wheat for shipment and storage, drawing its supplies from other markets. Some of its elevators have a storage capacity of 2,800,000 bushels, and are built of steel. Electricity, derived from the Niagara Falls, operates the elevators, which are protected from fire by pneumatic water systems.

Lake vessels are unloaded at Buffalo by means of spouts or "marine legs," which are let down into the hold, and the grain is then drawn up into the elevator. Scoops, pulled by mechanical power and guided by hand, are used to convey the grain from different parts of the hold to the "marine legs." Ten thousand bushels per hour can be unloaded from vessels, while the spouts on the other side of the elevator can reload grain into cars five or ten at a time. The time to fill a car, under favourable circumstances, is very short. The average for a number of cars at Buffalo in June, 1909, was ten minutes each, including the time required to move one car out of, and another into, position under the elevator spout. The cars were moved by means of a cable operated by machinery in the elevator. The contents of an elevator 
bin of 500 bushels are discharged into cars in the space of two to three minutes, while a canal boat of 8,000 bushels' capacity can be loaded in about an hour. At Chicago and Duluth, lake vessels are loaded by means of a number of spouts or legs, one for each of a number of hatchways of the vessel.

Elevators at the primary markets having a capacity of $1,000,000$ bushels are capable of receiving and delivering 15,000 bushels per hour.

On the Pacific Coast and in Argentina, there are no great primary markets in the interior; the destination of the wheat is the seaport, so that in these regions the storage of wheat has, for all intents and purposes, but three aspects.

\section{Storage of Wheat at the Seaboard.}

There is not the need for elevators at the ports to be as large as those at the primary markets, for wheat is only stored in them to await shipment abroad. The largest elevator on the Atlantic Coast has a capacity of about 1,800,000 bushels, and can unload grain from cars at the rate of 560,000 bushels per day, and deliver to vessels at the rate of $1,000,000$ bushels per day, both operations going on sirnultaneously. The record in elevator loading of steamers with wheat was made in 1906, when a steamer at Fort William was loaded with 198,000 bushels in one hour and fifty-seven minutes, or at the rate of 3,046 tons per hour.

The terminal facilities of a railroad at a seaport include tracks, wharves, warehouses, elevators, and appliances for transferring freight. The capacity for handling cars 
is about 1,000 cars per day for a large-sized terminal, and sometimes as low as sixty-five cars per day for a smaller terminal at an important seaport. In some cases, two or more railroads will use the same terminal as a port. A usual size for an ocean steamship pier is about 250 feet wide, and about 800 feet long. In the middle of the pier are railroad tracks, and on either side ocean vessels are moored. Grain in bulk is easily loaded on a vessel by transferring it through spouts running from the elevator to the hold of the ship. After a considerable quantity of grain has been loaded, a number of men called "trimmers" go down into the hold, and with wooden shovels level off the grain. This process is called "trimming." The loading of a ship with grain in bulk takes but a relatively short time, for each hatchway may be supplied at the rate of 20,000 bushels per hour, and with three hatchways it would take but a few hours of actual running to fill the hold of the largest steamship. There are two different arrangements made for loading grain on a vessel, while it is alongside a pier taking on board other freight. One arrangement is a series of belt conveyors running along a gallery above the pier. Along the sides of the gallery are spouts, which may be lowered to the hatches of the vessel, and the grain thus transferred to the hold. The other arrangement is by means of a floating elevator. Boats containing the grain are towed alongside the ship, and a floating elevator conveys the grain up from the boats to the top of its tall towers, and then lets it run into the vessel's hold.

The following table gives the elevator capacity at the various Atlantic and Gulf ports in 1908 : 


\begin{tabular}{|c|c|c|c|c|}
\hline & & & & \\
\hline New York & $\cdots$ & & & $13,230,000$ \\
\hline Baltimore & .. & $\cdots$ & . & $6,350,000$ \\
\hline Philadelphia & $\ldots$ & $\ldots$ & $\ldots$ & $3,550,000$ \\
\hline Boston & $\cdots$ & $\cdots$ & $\ldots$ & $2,000,000$ \\
\hline Montreal & .. & .. & .. & $4,125,000$ \\
\hline Newport News & & .. & $\ldots$ & $2,650,000$ \\
\hline New Orleans & .. & .. & . & $4,200,000$ \\
\hline Galveston & $\ldots$ & $\ldots$ & $\ldots$ & $3,800,000$ \\
\hline
\end{tabular}

On the Pacific Coast, large grain warehouses take the place of elevators at the ports. These warehouses are supplied with cleaning and grading plants. Sacks of wheat may often be seen lying piled on the banks of the rivers. If the deck of a vessel to be loaded lies at a lower level than the grain, the sacks are first elevated by a conveyor, consisting of a chute and an endless belt, and then they descend. These methods are more expensive, and take longer time than the elevator system ; three or four days are required to load a ship with from 3,000 to 3,500 tons of wheat.

Shipping facilities at the river and ocean ports of Argentina are unable to cope with the amount of wheat ready to be exported in the busy seasons, but great efforts are being made to improve the conditions. The port of Buenos Aires belongs to the National Government, which has expended much energy and money in providing facilities for trade. A long row of sheds containing machinery for the transport of grain in bags is one of the latest efforts. Charges are kept low for the flush of the crop delivery. At a cost of about $£ 1,000,000$ sterling, there have been erected at Buenos Aires a series of grain elevators fully capable of dealing with the traffic of the port at ordinary times. These are placed alongside the dock quays, where the largest vessels can be berthed, 
and the cargo shipped in bulk; while, if need be, the arrangements permit loading in bags. All the railways having connection with the capital are also granted facilities for running trucks alongside the elevators, warehouses, or vessels, as may be necessary. In 1909 there was erected at Buenos Aires a silo installation, with a storage capacity of 80,000 tons of wheat; right in the centre is a floor granary, in which 20,000 tons of wheat can be stored in bags. The conveying machinery in the silo house and floor granary has an hourly capacity of 1,200 tons of bulk grain, and 3,000 bags of wheat. The ship elevator has a capacity of 100 tons per hour, and has been erected on the water side of the shipping warehouses, for the purpose of clearing vessels, which bring wheat down from the grain-bearing districts along the banks of the great Paraná River. Rosario has a high "barranca," or river-bank, enabling shippers to load at a moderate expense by means of chutes from the trucks down into the holds of vessels. The system of elevators and warehouses is on a large scale, and all the railroads entering the city have access to the wharf. In common with the minor river ports, Rosario experiences considerable alteration in the depth of water, and great vigilance is necessary at times in securing vessels getting away with the right quantity on board to allow of their proceeding safely down the channel. At Bahia Blanca much money has been spent on elevators and machinery; the Southern and Pacific Railroads serving it have each their own " port" here, and compete with one another in providing the best facilities for shippers. Ships are loaded at Bahia Blanca by elevators; by steam winches, which 
lift the bags from the cars into the ships lying alongside; and by men, who carry the bags on board in the old primitive way. Sometimes the bags are carried by an endless belt, operated by electricity, from the cars about 100 feet to a short chute, that lands them on to the deck of the ship. In the busy season, when ships have to wait a long time for berths, they sometimes take on cargo by lighter at Bahia Blanca.

Of ocean vessels conveying wheat to foreign markets from the seaboard there are two main classes-liners and tramps. The first class consists of vessels belonging to a regular line-that is, a group of vessels plying over the same route, voyage after voyage, and having more or less regular times of sailing. Vessels of the second class, commonly called "tramps," have no regular routes or times of sailing, but go from port to port, seeking business, usually for a single voyage at a time. The fact that farm products are ready for shipment in a given country in large quantities only at certain seasons of the year makes the tramp ship practically a necessity. The large quantities of wheat gathered soon after harvest at the seaboard for shipment to foreign countries could not, as a rule, be handled by the steamship lines plying from the various ports, so it is necessary for some independent vessels to assist in handling the business.

Wheat is one of the most important of all articles carried on the ocean. For the greater part of the year, there is surplus wheat awaiting shipment at some port on the American coasts. By January and February, the wheat exports from the Pacific Coast of the United States have begun to arrive in Europe in considerable quantities; 
in March, the wheat ships from Argentina and Uruguay are arriving in Europe with their first cargoes of any importance. Winter wheat of the United States first reaches the ports of Western Europe in August. United States spring wheat begins to cross the Atlantic in considerable quantities in October, and Canadian spring wheat in November.

Both liners and tramps are now built much larger than in the past. The cargo of a tramp ship not infrequently includes the product of 15,000 acres of average wheat land ; and it would take two such cargoes to fill the hold of one of the large freight liners. Sailing vessels in the grain trade are being supplemented more and more by steamships, in spite of the progress in construction and operation of the former ships. Even in the grain trade of the Pacific Coast, steamers are competing with the sailing vessels for the carrying of grain to Europe. The steamers make the trip in about eleven weeks, while the sailing vessels require from seventeen to nineteen weeks.

Storage Charges.-The great developments that have taken place in the wheat industry, and the transportation facilities now existing, which enable through shipments, have eliminated or lessened many of the charges incident to the storage and handling of wheat. The higher charges for handling and bags on the Pacific Coast and in Argentina are used as an argument in favour of the elevator system. The jute sacks used add a cost of nearly 4 cents per bushel of wheat. Where storage was provided at Argentine local stations in 1903, the charge was 6 cents per bushel of wheat, and at least one month's rent had 
to be paid in advance; now, Argentine law compels free storage of grain for export. The greatest expense is incurred in the handling of grain where bags are used; and where the elevator system is in vogue, storage charges are the heaviest item. The rates of storage at the local elevators, taking the Canadian North-West as representative, are as follows :

For receiving, cleaning, insuring against loss by fire, handling, storing fifteen days, and ship-

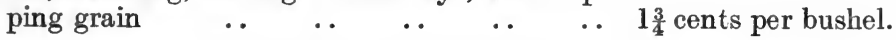
Each succeding thirty days, or part thereof $\quad . \quad \frac{3}{4}$ cent , , ,

Where competition is strong, and farmers' elevators are in operation, the above charges may be cut down to as low as $\frac{1}{2}$ cent per bushel.

The following table gives the storage charges at the primary markets and lake ports :

Duluth .. 0.50 cents per bushel first 15 days; $\cdot 025$ cents per bushel for each day thereafter.

Buffalo .. 0.50 cents per bushel elevating, including 10 days' storage, each succeeding 10 days or part thereof, 0.25 cents per bushel, loading into canal boats free.

Milwaukee.. 0.50 cents per bushel, including 10 days' storage and elevating; each succeeding day 0.02 cents per bushel. Rates include unloading and loading from or to cars or vessels.

Chicago .. 0.75 cents per bushel first 10 days or part thereof; - 025 cents per bushel each succeeding day.

Minneapolis 0.75 cents per bushel first 10 days or part thereof; $0 \cdot 25$ cents for each 10 days thereafter.

St. Louis .. 1.00 cents per bushel first 10 days, and 0.375 cents per bushel for each 10 days thereafter.

Fort William $)$ 0.75 cents per bushel elevating, including 15 days' Arthur $\}$ storage, and 0.75 cents for each succeeding 30 days. 


\section{Storage Charges at the Seaboard.}

Montreal (C.P. Summer storage (May 16 to November 14), Cents per elevating, including 10 days' storage .. $\quad 0 \cdot 75$

Storage for each succeeding 10 days or

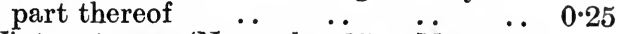

Winter storage (November 15 to May 15). (Between these dates when charges at regular rates accrue to $1 \frac{1}{2}$ cents per bushel, no further charge will be made.)

Grain remaining in storage after May 15, and for each succeeding 10 days or part thereof, in addition to accrued charges

New York .. Receiving, weighing, and discharging, on all sound grain, including storage, first 10 days, or part thereof

Every succeeding 10 days, or part thereof

Extra storage on grain delivered to ocean

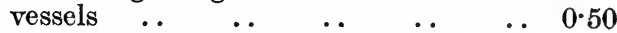

Screening and blowing on receipt or de-

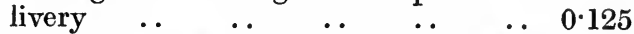

Inspection charges, 25 cents per 1,000 bushels.

Grain loaded from elevator to car .. 0.50

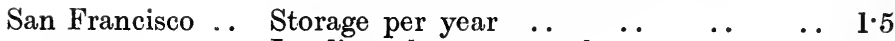

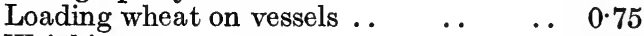

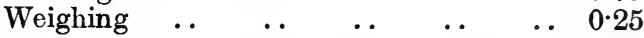

Buenos Aires .. Three days are allowed in the port for unloading cars, after which the railway companies charge 85 cents per car per day.

$\begin{array}{lllllll}\text { Weighing } & \ldots & \ldots & \ldots & \ldots & \ldots & 12\end{array}$

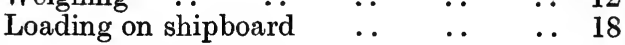

It costs about 1 cent per bushel more at the ports to handle wheat in sacks than it does by the elevator methods. A close study of this chapter will show that Canada and the United States possess advantages over Argentina in storage facilities and charges. They also possess advantages as regards total transportation charges on wheat for export purposes. The development of Argentine storage facilities is sure to be slow, but there is no reason to doubt that progress will be continued. 


\section{CHAPTER IX}

\section{MARKETING OF WHEAT}

THE development of the marketing of wheat in America provides one of the marvels of the present age. Wheat has been, and is, one of the main factors in the development of America. The pioneer husbandmen were followed by the merchants, and in their wake followed the improvements in transportation and storage systems, and the development of an excellent marketing system. The marketing of wheat by the farmer, and the movement of wheat to the primary and the world markets keep gold or currency in motion, thus giving life to trade, and making the development of new lands possible.

It is easy to trace America's agricultural and commercial greatness largely to wheat. Wheat is essentially the pioneer crop, which enables the farmer to exist, while the foundation is laid for diversified agriculture. In its westward movement wheat left behind it prosperous farming communities, towns, and trading centres. The history of Canada as an agricultural country shows that wheat leads railroad-building and commerce.

The practice of marketing millions of bushels of wheat within six to eight weeks after harvesting, the storing of millions of bushels at the local elevators, primary markets, and seaboard, the rise of grain exchanges, and the im- 
mense amount of money required to move the wheat crop, attach general interest to wheat.

There are three methods of marketing wheat utilized by the North American farmer, and which method is chosen by him depends largely on the amount of wheat at his disposal. The "bonanza" farmer usually makes a wholesale disposal of his crop to a buyer at the primary market, or he employs an agent at the chambers of commerce, or boards of trade at the primary markets, who sells to millers, exporters, and other buyers. Less extensive growers establish relations with commission agents at the primary markets, and usually obtain prices closely approximating to the market quotations. Small farmers sell to the local elevators, and the competition between local buyers often results in a fair price to the farmer. Such sales are always for cash. Where the farmers form associations, and provide themselves with elevator facilities, they do their own shipping, and sell through commission merchants. Throughout Minnesota and North Dakota, farmers have established a large number of co-operative elevators, and so are enabled through their managers to sell their grain direct to purchasers at Duluth and Minneapolis.

The headquarters of the line elevator companies, who own or control large numbers of country elevators, are at the terminal markets. Their agents at the country stations buy direct from the farmers, and thus the middleman's charges are eliminated.

The Argentine small farmer, or " ranchero," suffers many disadvantages in the selling of his wheat. Frequently he falls into the clutches of the "almacenero," or general 
store man. This person is ready to provide all necessary provisions, implements, etc., on terms profitable to himself, including the financing of the crop when harvested. $\mathrm{He}$ is thus the man who has grain to sell to the trader or to the port miller, and he can continue the process indefinitely if the grower remains in his power. His store is usually at the railway-station. Even if the "ranchero" does not fall into the hands of the "almacenero," he finds it by no means easy to market his produce, for grain is not a negotiable asset in Argentina, and the banks do not aid him in dealing with his produce. Again, he cannot provide the buyer with a uniform quality of wheat, nor any exact details as to his produce. Thus, when he wants money, he has to accept what the agent of the exporter will give him.

The local grain dealers and the dealers who represent the terminal grain buyers both buy wheat in the country districts of North America, and are usually located within hauling distance of the farms. Independent grain dealers, though often suffering from insufficient capital, have often the farmers' sympathy and aid. Their economic effect is to raise prices for the farmer. Frequently they are subjected to the keenest competition, and their opponents, the elevator combinations, are aided by the railway companies, who promptly supply them with cars in the busy season, refuse to grant sites for independent elevators along their lines, and grant them rebates.

One of the chief conditions for market development is that there should be an accurate description of the commodity dealt in, so that inspection by each buyer may not be necessary. Formerly wheat was sold by sample, but 
the selling of vast crops was so difficult under this method that grading was established. Rigid grain inspection and grading not only facilitate marketing, but they tend to minimize fraud. The procedure in wheat inspection is much the same at all the primary markets, and Minneapolis is here taken as representative. There are fifteen railroad yards at Minneapolis, and nine at DuluthSuperior, where inspectors are stationed to intercept and inspect grain on its arrival from outside points.

All grain, except such as is billed to points beyond, is inspected and weighed by the state department. As the cars arrive, they are placed by the various railroad companies upon the inspection traoks provided in the railroad yards. In each yard the deputy-inspectors, who are wheat experts, together with their helpers, are on the ground early every morning in winter and summer. The work is begun by one of the helpers breaking the railroad seal on one side of the car, and throwing the car doors open. He then records the number and initials of the car, the number of the railroad seal broken by him, and any appearance of leakage in any part of the car.

Next follow the samplers, who represent the commission firms on the Board of Trade, and who make it a point to procure a sample of the grain from each car-load consigned, so that disposal of the grain to customers may be made by sample as well as grade. Often an advance over the regular grade price is thus secured. Commission merchants usually keep the samples for reference for about thirty days to secure themselves against dispute.

The deputy-inspector, with the aid of his second 
helper, then proceeds to carefully examine each carload of grain, and to determine its proper grade and dockage. (Dockage consists of weed, seeds, dirt, chaff, etc. In nearly all the important markets, instead of assessing dockage, the grade is lowered.) The helper pushes a long brass probe into several places in the grain under the direction of the inspector, who stands on a ladder at the door opening, and each time draws up a section of wheat from top to bottom, and brings it to the inspector for examination. From these samples the grade is determined. The dockage per bushel is determined on the judgment of the inspector, when he considers it does not exceed $1 \frac{1}{2}$ to 2 pounds per bushel; above this it is arrived at by careful testing with a scale and a sieve.

In each case the inspector records in his book the car number and initial, the grade, dockage, test weight, and reasons for making the grade. A card is attached to each car door showing similar information. The inspector knows nothing as to the point from which the grain came, nor who the shipper may be.

Hundreds of car-loads of grain arrive each year, that contain good grain on the top of the load, and poor or damaged and dirty grain on the bottom. It is rarely such cars escape detection, as the brass plunger usually discloses evidence. The penalty for deception is a severe one, for the whole car is graded at the same value as the poorest grade in the car. In determining the grade of the grain, the unit of quantity is a car-load, except where a car is divided by a partition, and contains two different kinds of grain. 
During the busy season in the fall, when receipts are large, the deputy-inspector commences work at daybreak, and he has to work rapidly in order to get his report "on change" at least by 10.30 a.m. His morning's work completed, the deputy-inspector immediately repairs to the chief deputy's office, where he prepares from his track-book a report of all the cars he has inspected. The clerical force of the inspection office is at this time kept exceedingly busy furnishing this information verbally and by telephone to the members of the Board of Trade, as it must be had by them before the grain can be sold and disposed of. In the meantime, the helpers who are left on track are engaged in carefully closing the car doors, and sealing them with state seals, making a record in each case of the seal number, and the hour of the day when the seals were attached.

The samples and the grades having been furnished, the business of buying and selling on the Board of Trade begins in earnest. Between 10 a.m. and 1.15 p.m. a busy scene is presented. Buyers flock around the sample tables, first picking out the choice cars, and gradually supplying their needs for the day.

As fast as sales are made, the samples are removed, and by 1 p.m., unless there is a very dull market, most of the grain will have been disposed of. The railroads are then notified to which mills and elevators the different cars are to be switched, and the work of distribution commences. The railroad companies demand prompt disposition of grain by commission merchants and others, particularly in the busy season, in order that the cars may be emptied and returned quickly to the country 
stations. If grain is not disposed of on the day of arrival, a demurrage of $\$ 2$ per car per day is exacted.

Persons dissatisfied with the first inspection of the grain are at liberty to order a re-inspection. In the case of a country shipper, this order is usually made by his commission merchant, and the order must be filed at the office of the chief deputy-inspector before the grain has been unloaded, and so lost its identity. This second inspection is made by the chief deputy or his first assistant, in which case a careful examination of the car-load is made ; and, if it is found to be a doubtful case-that is, on the border line of the grades, the benefit of the doubt is given, and the grade is raised. If, however, the first inspection was just, it is confirmed, and a charge of $\$ 1$ per car is made. If the parties interested still feel aggrieved, they have the right of appeal to the Board of Appeals, whose decision is final and binding on all parties.

Before any final accounting can be made by a commission merchant to a country shipper, or any settlement arrived at between buyers and sellers in their transactions, the correct weight of the grain must first be ascertained. This weight is determined by deputy state weighers stationed at the terminal elevators and mills, who take charge of the grain on its arrival at their respective stations, and carefully weigh the same before it is delivered into the possession of the buyer.

At the large elevators an additional or supervising weighman is employed to examine the car on its arrival at his station, to note the condition of the seals, and also whether there has been any leakage, or pilfering of the grain. After the grain is unloaded at the mill, or elevated 
to the hopper at the top of the elevator, it is carefully weighed by the deputy state weigher in charge, and a record is made by him of the gross weight in each case, each day's work being reported in detail at the office of the state weighmaster. Certificates of weight, like those of inspection, are freely furnished, without charge, upon application. State weighing at Minneapolis is done at thirty-eight elevators, twenty-four mills, and four railroad yard scales ; 50 tons may be weighed at one time on one machine.

Commission merchants and others desiring certificates of weight of their grain can be found crowding the office of the state weighmaster each morning for weights of cars, which were sold and disposed of during the previous day. This enables them to complete their account of sale to their country shippers. These statements and remittances of the balances due are forwarded to the country shipper, as a rule, on the same day as the state weights are ascertained.

The transportation of wheat from the interior of North America to the seaboard, or from the local station to the primary market, usually involves from three to six inspections of the grain.

The total amount of wheat inspected " on arrival " in 1907 at the terminal points of Minnesota-viz., Minneapolis, Duluth, St. Paul, St. Cloud, New Prague, Sleepy Eye, Kasota, Montgomery, and New Ulm-amounted to 113,592 car-loads.

At Minneapolis, in the afternoon, when all the incoming receipts of grain have been inspected and reported, the deputy-inspectors are in readiness to inspect and grade 
the grain that has been loaded during the afternoon into cars from the large terminal elevators. These shipments, intended either for export or for flour mills, are all subject to state inspection and weighing before their departure. It is rare for any buyer to accept grain unless accompanied by a state certificate of inspection and weight.

Frequently in the busy season, the shipments from the Minneapolis elevators aggregate to 400 or 500 car-loads daily; while, at Duluth, it is not an uncommon occurrence to inspect and weigh out $1,000,000$ to $1,500,000$ bushels into vessels in a single day. The same care and attention must be exercised in this feature of the work as is done in the case of incoming grain, in order that standards shall be rigidly maintained, and the reputation and prestige of Minnesota grades be preserved in the world's markets.

Grain inspection can never be rigidly accurate; it is a work of judgment, guided by fixed rules, but which allow the inspector latitude for applying his powers of discrimination. Though no man can inspect grain to the satisfaction of all concerned, yet the system works well, only a comparatively small percentage of appeals against the inspectors being upheld.

In Canada, a Bill was passed in 1904 providing for the Eastern and Western inspection of grain. The system of inspection, controlled by law, is similar to that of the United States, and the fixed fee for inspection is 40 cents per car, the cars averaging about 1,000 bushels each.

The commercial grades of wheat arose owing to the largeness of the markets, the keen competition, men's experience in the value of the different types of wheat, and 
the modern aids of science. A glance at the rules, fixing the grades of wheat, will show that the principal characteristics aiding the inspector in assigning the grade are weight per bushel, the colour, soundness, and plumpness of the kernel, and the amount of foreign matter present. Grade conditions are naturally expressed vaguely, and the grain inspectors have the responsibility of their interpretation.

To sell wheat, by sample only, becomes exceedingly difficult when the amount is vast. This was felt in the United States first, and she established grading in the fifties of the last century. She was followed later by Canada, but in Argentina grading is still the exception rather than the rule.

The grain trade made a vast stride, when it allowed wheat of the same grade to be stored in bulk without preserving the identity of each particular lot, and so made it possible for the issue of general receipts for the specified amount of grain of the particular grade or grades stored. To fulfil a contract now, it is not necessary to deliver the actual lot, but a similar amount of the same grade may be delivered, or a grain receipt may be given.

Trade organizations, such as Boards of Trade and Chambers of Commerce, afford means of easy communication between producer and consumer, and each organization has established its "contract grade" of wheat for its own market. These "contract grades" vary in different markets owing to the difference of rules, and confusion sometimes results. The lack of uniformity in the ordinary grades is also a distinct drawback; only Canada has uniform grades. The United States Secre- 
tary of State for Agriculture, in his report for 1908, says : "While many of the influential grain dealers of the country are working hard to bring about a more satisfactory and uniform system of inspecting and grading grain in the various markets, it is believed that the end to be attained can be brought about only through national inspection of all grain entering into interstate and foreign commerce."

The commercial grades of wheat recognized at Chicago are as follows :

White Winter Wheat: Nos. 1, 2, 3, and 4.

Long Red Winter Wheat: Nos. 1 and 2.

Red Winter Wheat: Nos. 1, 2, 3, and 4.

Hard Winter Wheat: Nos. 1, 2, 3, and 4.

Colorado Wheat: Nos. 1, 2, and 3.

Northern Spring Wheat: Nos. 1 and 2.

Spring Wheat: Nos. 1, 2, 3, and 4.

White Spring Wheat: Nos. 1, 2, 3, and 4.

Wheat of poor quality or condition is classed "rejected" or " no grade."

An idea of the rules governing the grading of wheat may be gained from the following rules on the Minneapolis market :

\section{"Northern Spring Wheat.}

"No. 1 Hard Spring Wheat shall be sound, bright, sweet, clean, and consist of over 50 per cent. of hard Scotch Fife, and weigh not less than 58 pounds to the measured bushel.

"No. 1 Northern Spring Wheat shall be sound, sweet, and clean ; may consist of the hard and soft varieties of 
spring wheat, but must contain a larger proportion of the hard varieties, and weigh not less than 57 pounds to the measured bushel.

"No. 2 Northern Spring Wheat shall be spring wheat not clean enough or sound enough for No. 1, but of good milling quality, and must not weigh less than 56 pounds to the measured bushel.

"No. 3 Northern Spring Wheat shall be composed of inferior, shrunken spring wheat, and weigh not less than 54 pounds to the measured bushel.

"No. 4 Northern Spring Wheat shall include all inferior spring wheat that is badly shrunken or damaged, and weigh not less than 49 pounds to the measured bushel.

"Rejected Spring Wheat shall include all varieties of spring wheat sprouted, badly bleached, or for any other cause unfit for No. 4."

The "contract grades" established on the various markets are understood in all contracts not specifying otherwise. On the Winnipeg Exchange, No. 1 Northern is the "contract grade," with the privilege of delivering No. 1 Hard on contracts, at 1 cent premium over No. 1 Northern ; with the privilege of delivering No. 2 Northern on contracts, at 3 cents discount under No. 1 Northern; and the privilege of delivering No. 3 Northern on contracts, at 10 cents discount under No. 1 Northern.

After the fixing of grades, houses were established at the terminal points for the removal of seeds and shrunken and blighted grains, in order to raise the grain to the standard for delivery upon contract. This was a step to the system of mixing grains of higher grade than that necessary to pass as contract, but which were worth more 
than the contract grades to millers, with others of lower grade than the contract, bringing the whole to such a state that it would pass muster according to the rules of the various inspection departments for which the mixture was made. This business results in large profits, but has the effect of lowering the grade of wheat to the disadvantage of the producer. Before the establishment of an Eastern and Western grain inspection in Canada, it was alleged that Manitoba spring wheat was mixed with Ontario spring wheat to the disadvantage of the former.

No system of Government inspection of grain has ever been tried in Argentina, and exporters are opposed to Government inspection, and only in a small minority of cases at present do they care for private inspection. Wheat is supposed to be inspected by a representative of the buyer in the local station, by means of a "tryer "- a pointed tube-that is thrust into each bag bringing out a section of its contents. Great dexterity and expert knowledge are needed to estimate each bag correctly in the short time at the inspector's disposal. The inspection is made as the bags are carried by the peons past the inspector from pile to car. The local merchant or the representative of the large buyers has to keep a sharp watch lest bad wheat shall be bought cunningly mixed with good. Nearly all wheat must be reinspected, sorted, or cleaned at the ports before exporting, and much delay and annoyance are thus caused.

Little official grading of wheat is done in Argentina, and where it is done, as by the Rosario Board of Trade, it is not very strict. In the markets, the buyer usually fixes his own standard, which in all cases refers to the 
natural weight, amount of dirt, broken grains, and foreign seeds, dryness, and freedom from smut. Buyers prefer to rely upon their own judgment and knowledge in dealing, rather than a system of strict grading, as in North America. Export wheat is classed by the exporter as either special, superior, good, or inferior.

The furnishing of money for the moving of the crops in North America is one of the best examples of financing to be found in the modern commercial world. Banking has now spread to the rural districts, and the great money centres are not now such important factors in the moving of wheat. The farmer is usually paid in cash, and so, when the harvesting of wheat is over, millers, grain buyers, and elevator owners must be provided with money. The Industrial Commission of the United States reports that about $\$ 500,000,000$ is required (apart from the money used by the railroads) to move the grain crops of the United States. A large grain buyer in the Middle West may require from $\$ 100,000$ to $\$ 150,000$ for the first day's payments. He is kept informed by his correspondents at the elevator towns as to the amount of cash required each day.

Wheat in North America can always readily be converted into money, for warehouse receipts are good security, and money may be borrowed on them from the banks close to the cash price of the wheat. Grain paper is steadily growing in favour with bankers as a short-time loan for their surplus money. The development of banking largely aids the grain trade; to the small farmer, who has not now to wait for his money, its benefits are great. It is the custom for the country dealers, when 
cars are loaded, to draw sight drafts on the commission agents selling for them at the primary market, and to deposit these with the bills of lading attached in the country bank as cash items. Drafts may be honoured by the commission agents, on whom they are drawn, a number of days before the consignment is received by them. Such advances, according to the rules of the Boards of Trade and Chambers of Commerce, must bear interest. After the grain has been sold, the commission agents deduct from the proceeds the freight charges, their commission, fees for weighing and inspecting, and other expenses, which include any advances that they may have made by cashing drafts, and remit the balances to the shippers. At the terminal warehouse, and again when exported, the wheat is available for a loan approximating closely to its market value. Farmers wishing to hold their wheat place it in an elevator, and the grain receipt obtained enables them to borrow from the banks up to about 90 per cent. of the value of the wheat.

In Argentina, with its lack of inspection and grading, it is easy to see that the grain business in the country districts has not yet reached the point when effective security can be given to banks or other finance authorities ; any change in the method of conducting the trade must obviously include the provision of such security based upon the produce itself. It would scarcely seem to be necessary to define with great exactness either quality or weight, for a very moderate extra margin on advances would cover the risks, if due care is taken to keep the goods intact. The buyer in the country is financed by the grain exporter, and is paid 1 per cent. 
commission on all that he buys. A price is telegraphed to him in the morning, and this he pays all day, as he rides from point to point.

At the primary markets, cables are frequently sent at night to every market of the world in order to sell wheat. Wheat, that cannot be sold, must be held, and future sales on the speculative markets are usually made to provide against price fluctuations.

Wheat at the primary markets is either bought by millers, elevator companies, or by grain exporters to Europe and other countries. The great grain-exporting houses either at the Atlantic, Gulf, or Lake ports have correspondents in all the importing countries, and also in all the primary markets. They usually buy both by grade and sample, except Duluth wheat, which is generally bought on Duluth certificate of inspection.

Wheat is usually insured, whether in transit or in store. In the elevators at the local markets, wheat can be insured at a rate varying from 1.5 to 3 per cent. per annum, depending upon the construction of the elevators and the risks run. The rate for grain in transit ranges from 0.60 per cent. to 1.50 per cent. For grain in the terminal elevators the rate varies from 0.50 to 3.15 per cent., depending upon the type of elevator and its surroundings. In Canada the law compels warehousemen to insure wheat, and the average rate of insurance is nearly 2 per cent. Marine insurance usually ranges from 1 to $1 \cdot 25$ per cent.

For perfect market development-that which allows speculation-four general conditions are necessary. These are summarized by Professor Chapman as follows :

"1. That the commodity should satisfy a demand, 
which is constant over a fair period, and is not given to violent fluctuations; and that it should be elastic rather than inelastic at the point about which the marginal demand oscillates, so that increased or decreased supplies are not followed by very large variations in price. To this condition must be added that supplies should not be subject to violent and entirely unforeseen fluctuations ;

"2. That there should be an accurate description or ' grading' of the commodity dealt with, so that inspection by each buyer may not be necessary ;

" 3 . That full and immediate information about facts affecting prices be made publio; and

"4. That there should be facilities for bargaining and payment."

Professor Marshall says: "The Elasticity of Demand in a market is great or small, according as the amount demanded increases much or little for a given fall in price, and diminishes much or little for a given rise in price. If a fall in price is followed by increased total takings, demand is said to have an elasticity greater than one-it is comparatively elastic ; but, if a fall in price is followed by diminished total takings, the elasticity of demand is said to be less than one-demand is comparatively inelastic."

Wheat is one of the world's principal breadstuffs, and is, to a great extent, a necessity, more so now, perhaps, than formerly, for though there are many substitutes for wheat, and world commerce allows a wider range of products, yet the number of wheat eaters is increasing as civilization advances. The Japanese and Chinese have commenced to make wheat one of their food products; 
the German and Russian peasants, largely rye-eaters, are commencing to substitute wheat, so that, though the British Isles and the United States are lessening their per capita consumption of wheat, the tendency seems to be an increased world demand for this commodity. Fears have even been expressed that consumption may overtake the production of wheat, even when making allowance for the discovery and exploitation of new wheat lands.

The supply of wheat has already been shown to be dependent on climate, soil, and many other factors, but the great number of countries with varied types of climate growing wheat makes the supply fairly constant.

The demand for wheat is comparatively inelastic, and to this the success attending various "corners" is largely due. When the price of wheat is very high, and again when it is very low, the demand has very little elasticity ; this is at least true if the assumption is made that wheat, even when scarce, is the cheapest food for man, and even when it is most plentiful it is rarely consumed in any other way. Great variations in the price of wheat are possible, and have not been very uncommon; thus, wheat was sold in Liverpool for 20s. the quarter in December, 1906, but in the following October the price was 31s. per quarter. Speaking generally, however, wheat prices are not, on the whole, subject to greater variations than those of products like cotton, which allow almost perfect market development.

Grading of wheat in North America has been shown already to be an aid to marketing, and though it is not perfect, the accuracy of the grading is comparable with that of cotton. 
The laying of the Atlantic cable, and the perfecting of postal and telegraph networks enable information with regard to wheat to be disseminated throughout the world. The amount of wheat in store, the amount of wheat afloat, and the prospects for the next harvest or harvests are not only known to the trader and speculator, but also to the farmer.

The facilities for bargaining and payment in the wheat trade supply one of the best examples existing in modern markets; the various methods will be discussed more fully later. To sum up, it is evident that conditions for almost perfect market development exist in the wheat trade.

The earliest market for wheat was of necessity the local market, and the natural limitation of factors with every phase of them known made it possible for local events of importance to violently affect prices. The next stage was the city market, where price was determined by the conditions of supply and demand over a larger tract of country, where greater knowledge of conditions was thus necessary, and where fluctuations of price were not apt to be as violent as in the local market, though great fluctuations might at times occur. The growth of wheat territory, the excellent transportation facilities afforded, the excellent storage conditions existing, the spread of information, grading, and a world demand and supply, led to a world market for wheat. Price in each locality is determined now largely by the conditions of supply and demand in all parts of the world. Trade risks are thus very great, for no knowledge of local conditions, nor foresight regarding them, can protect a dealer from disastrous 
changes in value due to far-off occurrences. The growth of organized speculative markets was a result of these conditions. The greater the risks, the greater is the opportunity for, and the greater need of speculation. Traders necessarily became differentiated into two classes - the wheat dealer proper, who is in the market simply to secure trade profits as distinct from speculative profits; and the professional speculator class, organized in exchanges with a perfect method of facilitating business. The primary economic function of the speculator class is to bear the great risks, which are intolerable to the ordinary dealer.

Grain exchanges began to be organized in America in 1848 and 1849 ; they are corporations governed by a board of directors, who are elected by the members. The association provides a place in which the buying and selling are done by its members, and one of the most important functions is the making and enforcing of rules for buying and selling. Without these exchanges the grain trade would be chaos.

"Futures" can only exist where grading, elevator receipts, and an excellent system of bargaining and payment exist. A warehouse receipt for wheat is considered as good as the wheat which it represents, for wheat is a world-wide commodity, and thus acquires a credit value, which it would not otherwise have. Grain has a greater credit than land, and grain receipts have the same meaning in Liverpool, Chicago, or New York.

Much has been said for and against the system of future dealing, and it is certainly true that speculation does result sometimes in evil consequences, but modern 
economists are of opinion that speculation by experts steadies prices, and greatly aids trade. Mr. Justice Holmes, of the United States Supreme Court, says : "In a modern market contracts are not confined to sales for immediate delivery. People will endeavour to forecast the future, and to make agreements according to their prophecy. Speculation of this kind by competent men is the self-adjustment of society to the probable. Its value is well known as a means of avoiding or mitigating catastrophes, equalizing prices, and providing for periods of want. It is true that the success of the strong induces imitation by the weak, and that incompetent persons bring themselves to ruin by undertaking to speculate in their turn. But legislatures and courts generally have recognized that the natural evolutions of a complex society are to be touched with a very cautious hand, and that such coarse attempts at a remedy for the waste incident to every social function as a simple prohibition, and laws to stop its being, are harmful and vain."

There can be no doubt that speculation has been, and is, a distinct advantage to the American farmer. In the early days, a wheat dealer required a large margin for the risk of falling prices, and usually offered the farmer from 5 to 10 cents per bushel under the ruling market price. Now the dealer will buy on a margin of 1 cent per bushel.

Trading* in "wheat futures"- that is, the buying or selling of wheat to be delivered in some future month-

* For the various operations on the Exchanges, the author is much indebted to Professor H. C. Emery's "Speculation on the Stock and Produce Exchanges of the United States." 
is done on a margin basis-the depositing of a margin of a few cents per bushel on all the grain bought or sold. Trade risks are shifted to the speculators in two ways: (1) Through the existence of a continuous market; and (2) through the possibility of "hedging" transactionsa special device for insurance against loss.

The continuous market is the result of the countless opportunities for trade made possible by price fluctuations in world markets. There is a ceaseless stream of business in modern markets, new contracts being made with every change of condition of supply and demand. Into this stream the merchant or producer enters to make the necessary contracts, and here a price is fixed for the delivery of wheat of various qualities at various times. Suppose a Chicago dealer receives a bid on 100,000 bushels of wheat to be delivered in Liverpool at the end of three months. He ascertains the prevailing price of wheat, and determines at once the profit. If favourable, he immediately cables acceptance, and the same hour purchases wheat for delivery at such a time as will be most convenient for him to ship. The price of his wheat is known, and only the insurance and freight rates can affect his profit. Of course, this kind of business could bo done without the speculative market, but to a smaller extent, and intermittently.

"Hedging sales" provide almost complete insurance against loss. The merchant carries on two lines of compensating contracts, one in the speculative market, and the other outside. These contracts are of an opposite nature, and furnish a hedge against all price fluctuations. Probably nine-tenths of the wheat at the great depôts 
of Chicago, Minneapolis, and Duluth are protected by " hedging sales."

Speculative profits usually come from price fluctuations in the same markets, and trade profits from the difference in prices in the different markets. The trader, as a rule, buys in one market, and sells in another; the price difference in the markets furnishes the trader with his reward as middleman. The speculator buys and sells in the same market, and makes his profit or loss from fluctuations over a period of time. There is, of course, a tendency for the price of wheat in all central markets to be the same, but this condition is never actually reached.

"Bull" speculation on the markets is first buying and then selling at a later date; while "bear" speculation is the opposite of this. "Bull" speculators are said to operate on the "long" side of the market, while "bears" operate on the "short." "Bulls" run the risk of a fall in price, and hope to gain from a rise; the risk and hope of the "bear" are, of course, the reverse. Before the system of grading and grain receipts came into existence, "short" selling was impossible, and the speculative market was thus incomplete.

Grain privileges are a means of insurance against loss ; they are either "puts," "calls," or "straddles." A "put" is a contract made with a view to a fall in price. -The seller is enabled to limit his risk of loss to a definite amount. By paying a fixed sum of money, he acquires the right to deliver a certain amount of wheat at a fixed price and within a fixed period of time to the party taking the "put" money. If the price goes down, the seller purchases, and makes his delivery according to contract; if, 
however, the price goes up, he relinquishes the "put" money, and exercises the privilege of non-delivery. $\mathrm{He}$ loses the amount of the price paid, but he can lose no more; whereas the receiver of the "put" money only stands to win the "put" money, and may lose a great amount.

A "call" is exactly the reverse of a "put." A combination of a "put" and a "call" privilege is called in England a "put and call" option, but on the American exchanges a "straddle." The price of these privileges depends chiefly upon the distance they read away from the market, the state of the market, and the time the privilege runs. A "put" or "call" on the Chicago market generally sells at $\$ 1$ per 1,000 bushels. On many of the grain exchanges privileges are now forbidden.

If deposits securing future delivery of wheat are demanded, they must be met. Each party usually makes a money deposit large enough to secure the other from loss in case of non-fulfilment of the contract. On the New York market 10 cents per bushel of wheat is the maximum deposit. Occasionally, additional margins equal to the fluctuations in price are called for.

The rules of the various grain exchanges contemplate the actual delivery of wheat on the maturity of the contract. Each contract mentions the time for which it is to run, and its maturity is on the last day of this period. For export purposes the time of the contract is usually fixed by special contract, but on the speculative markets the current trading is in the deliveries for July, September, December, and May. The difference in price between wheat for immediate delivery and that for the next suc- 
ceeding delivery equals the carrying charge to the beginning of the period of the next delivery.

A speculator has three ways by which he can settle a contract on or before its maturity : (1) Either deliver the actual wheat, or (2) buy the same quantity of wheat in the same grain exchange, or (3) be mulcted in damages for non-delivery.

The speculator very seldom delivers the actual wheat in his possession. It is not necessary that he should possess wheat, for, before the contract falls due, he can secure the amount on the market. It is just as legitimate to make a contract for the future delivery of grain, buying or selling, as it is to get it at once ; and there are thousands of transactions in grain where the sellers do not have the grain, but expect to go into the market and buy it.

The "floor trader" or "scalper" on the American exchanges corresponds almost exactly to the jobber on the English exchanges. Both buying and selling brokers know the same things with regard to wheat, for the object of each is to get the best terms possible from the other, and so conflict ensues. The conflicting interests are brought together in the "floor trader," who expresses both demand and supply. The ideal "floor trader," with his complete knowledge of the demand and supply of wheat, will either buy or sell at a price which he quotes, before he knows whether he is required to buy or sell wheat. The public deals with the "floor trader" through a broker, who both buys and sells on commission. Brokers are a necessity, for buyers and sellers are frequently at a great distance from the market, and need information as to the state of the market, and the method of operation on 
it; again, if all buyers and sellers were on the market, confusion would result.

In the wheat pits of the exchanges brokers swarm, and all simultaneously make their offers to buy or sell. The confusion is so great that it is impossible to make written contracts. A word or a nod often results in a contract. The parties make entries quickly on their pads, and the buying and selling continue as before. Day after day the operations go on, and thus thousands of future contracts are made, in which brokers and dealers are mixed up in various relations. At the end of each day, the clerks of the traders compare and settle, and no written contracts are exchanged. Offsets being made, the remaining contracts are confirmed by the exchange of confirmation slips. When the sales and purchases of a broker have been made at the same price, the plan adopted is for his purchaser and seller to become parties to a new contract at that price, and the broker drops out altogether. It is possible also, where the contract prices are different, to settle the contracts by the paying of differences, but this is usually done by the clearing houses.

Often when settlement day comes, there is a long chain of transactions caused by speculators having bought and sold the same amount for the same delivery. A has sold to $\mathrm{B}, \mathrm{B}$ to $\mathrm{C}$, and so on. As soon as one of the persons in the chain makes a delivery of wheat by grain receipts, they are handed on from party to party, thus fulfilling all contracts in the line, and they finally come into the hands of the party, who wants the actual wheat for use.

Delivery by transferable order occurs, when the two ends of a line of traders do not come together. The owner 
of the wheat issues a transferable notice, which is a statement that he is prepared to deliver elevator receipts in fulfilment of his contract. This notice is passed to his buyer, and each seller in turn passes it on after proper endorsement; the last receiver presents it to the issuer, and demands the elevator receipts. If what the buyer has agreed to pay does not correspond with what the seller was to receive, the transfer is made at the official market price at the close of the previous day's business. The parties in the line then pay, or receive the difference between the settlement prices and the prices in their particular contracts.

Direct settlement occurs when there are only two parties, each being respectively buyer from and seller to the other. If A early in April sells to B 20,000 bushels of May wheat at 75 cents per bushel, and the price falls, he may make his covering purchase by buying the same amount from $\mathrm{B}$ say at 70 cents per bushel; the contract is then settled by $\mathrm{B}$ paying A $\$ 1,000$. Direct settlement is thus a payment of differences.

A "ringing out" settlement is like direct settlement, but between several parties. A has sold to B, B to C, $\mathrm{C}$ to $\mathrm{D}$, and so on. A must buy to cover, and D must sell to liquidate, or take the goods offered. If it can be arranged, $\mathrm{D}$ will sell to $\mathrm{A}$. If $\mathrm{A}$ issued a transferable order against himself, he would be the one to demand delivery; there is nothing thus to be delivered, for $\mathrm{A}$ is both deliverer and receiver. All that is necessary, then, is to "ring out" the differences, or, in other words, to reckon up the profit and loss of each one. This settlement differs from that by transferable notice only in that, 
when the time of settlement comes round, the two ends of the chain are connected. No ring can be formed if any one party insists on delivery of the wheat.

The ring settlement is the favourite, because differences are paid immediately on the formation of the ring, and profits can then be ascertained; whereas, in the method of delivery by transferable order, it is necessary to wait for the stipulated month of delivery.

The clearing-houses of the produce exchanges are in their functions much like those of the clearing-houses for banks. They facilitate the payment of differences on the deliveries, direct settlements, and rings of the previous day. Deliveries may be on any day of the month, but are generally made on the first day of the month, and so the clearings of the following day are the most important.

Clearing-houses act as post-offices, for when a grain contract is made, and is not settled by direct offset at the end of the day, the confirmation slip must be sent to the clearing-house directed to the other party within a specified time. When the settlement is made, each party to the transferable order, or to the ring, sends to the clearing-house comparison slips, addressed to the same parties as were the confirmation slips. On these comparison slips is noted the difference between the settlement price and the price in the contract between the two parties in question. A clearing-sheet must also be sent to the clearing-house stating the balance due to or from the members of the exchange, arising from the settlements as ascertained by exchanges of comparison slips. This sheet represents the profits and losses of the members in question for the day previous to the clearing. 
Speculators with an adverse balance must send with their report a cheque for that amount made payable to the order of the clearing-house. Parties with a favourable balance must enclose a draft for the amount drawn to their own order, and this draft may be demanded back duly approved at the times fixed in the rules. New York and Chicago clearing-houses exist simply for the clearing of differences, but in Minneapolis both grain and differences are cleared. Parties "long" and parties "short" on their net sales are ascertained by the Minneapolis clearing-house, and it also directs the deliveries of the grain.

Where the clearing-house does not exist, delivery is made by the holder of the grain to the last receiver by means of a delivery notice of some kind, and at a settlement price. Offsets and rings are effected whenever possible, and all differences are settled among the parties themselves.

Important classes of transactions on the exchanges are the contracts for immediate delivery designated as "cash" or "spot" sales. A cash payment is not necessarily implied, for the buyer and seller can make their own arrangements as regards credit, but "spot" sales do represent actual goods available in the market at the moment.

Some factors seem to suggest that speculation will decrease in the future. Statistics show that wheat prices are becoming more uniform, commercial wheat interests are growing in concentration, and local consumption of wheat will increase in America as population increases.

It is interesting to note that the Grain Exchange of 
Buenos Aires on March 16, 1908, put into force a future market system, and Buenos Aires quotations are now received in the European and American markets daily.

The export trade in wheat is of great importance to America. The ports to which wheat is originally shipped, and where orders are received fixing their ultimate destination, are called ports of call. Before arrival, the consignee at the port of call sells the wheat in the best market for the moment, and on its arrival gives orders for the vessel to proceed to the port where the goods have been sold.

The quantity of the wheat consignment and the port of shipment are specified in the contracts, but the port of delivery may, within stated limits, be left to the option of the buyer, and may be changed after clearing. The three ways of buying wheat for export are as follows : (1) Of fair average quality of the season's shipment at time and place of shipment (the so-called f. a. q. transaction); (2) at time and place of shipment as per sealed sample; and (3) official certificate of inspection to be final as to quality. This last condition, referring to inspection in the country of export, is the usual mode of purchasing grain from the United States and Canada. An important provision in the La Plata grain contracts, and absent in the North American contracts, is the guarantee of the natural weight.

A brief account follows of some of the most important wheat markets of America.*

Chicago, the greatest of lake ports, is not at the head of Lake Michigan, but nearly twenty miles north on the

* For a fuller account of the wheat markets of America, see Rollin E. Smith's "Wheat-Fields and Markets of the World." 
western shore. Here a river has been dredged, and docks built. From the prairies, the plains, and the passes of the northern Rocky Mountains, the railway-lines must meet round the head of Lake Michigan. Traffic from the south-west is drawn to the Lakes, and all lines from the far north-west concentrate on Chicago. Chicago is thus largely the result of railway and water transportation, and no small share in its growth must be assigned to the wheat traffic. Chicago is the greatest grain centre in the world, and, though surpassed by other primary centres in receipt of wheat, it yet receives annually about $25,000,000$ bushels of wheat. It is a great central world wheat market, because there are sufficient dealers there, so that wheat in any quantity can always be bought or sold. The membership of the Chicago Board of Trade includes representatives of every prominent grain commission and elevator company in the United States, besides European importers. Chicago receives its wheat from the states to the south-west and west, even as far as Kansas and Nebraska; and northwards as far as South Minnesota and South Dakota. On the floor of the Chicago Exchange meet the millers, elevator managers, the exporters of New York, Boston, and Philadelphia, the European importers, and the Argentine exporter, for the purpose of buying or selling wheat as a "hedge" against legitimate transactions in their regular business activities. The transactions in the market may be classed as "cash wheat" business and "future" business. Cash grain business includes receiving the actual wheat, selling it by sample, and shipping it to the elevators, or to the seaboard. Buyers not members of 
the Exchange must employ a broker, and pay commission for his services. The wheat pit, or "future " market, is often the scene of a tremendous volume of business, and the theatre of strife. Many of the traders in the pit are employed by commission houses ; others are brokers, who execute orders for any member on commission; while others are pure speculators. The "future " market, of course, has for its basis the "hedging" of the elevator companies, exporters, and millers. The unit of transaction in the wheat pit is 5,000 bushels. When brokers offer to buy or sell at a stated price, and no amount is mentioned, 5,000 bushels is understood. If a greater amount is offered or bid for, 10,20,50, or 100 are quoted, as the case may be, meaning $10,000,20,000,50,000$, or 100,000 bushels. All contracts made for wheat are in the "contract" grades-namely, No. 1 red winter wheat, No. 2 red winter wheat, or No. 1 northern spring wheat; No. 1 hard winter wheat, or No. 2 hard winter wheat, in such proportion as may be convenient to the seller. A higher grade than the "contract" is now also allowed, chiefly to prevent "corners." Probably 90 per cent. of all the transactions on the Exchange are pure speculation.

New York is one of the most important world wheatexporting markets, and its quotations have more influence in foreign markets than any other wheat-market quotations of America, with the exception of Chicago. It is well served by railways and by steamship lines, and its geographical position is very advantageous for trade with Europe. The importance of New York is due to its command of land and sea routes. The opening of the Erie Canal gave it a great impetus, and made it the outlet 
for a large and rapidly-developing hinterland. The construction of a railway up the Hudson and the establishment of steam communication with Europe further centralized its commerce. Numerous railways cross the Appalachians, but none are as important as the Hudson route, for their heavy gradients more than counterbalance the shorter distance. The northern route from New York by the main valley to Lake Champlain and the St. Lawrence is hardly less important than the Hudson route. New York has thus found it comparatively easy to beat Boston in competing for the bulk of the wheat traffic with the important hinterland of which Chicago is the centre. New York is the most important exporting port for grain and flour in the United States. Its "contract" grades of wheat are either No. 2 red winter wheat, No. 1 northern spring wheat, No. 1 hard spring wheat, or at a discount of 2 cents per bushel from contract price, No. 2 hard winter wheat or No. 2 white winter wheat; or at a discount of 5 cents per bushel from contract price, No. 2 red winter wheat or No. 2 northern spring wheat; or at a discount of 7 cents per bushel from contract price, No. 3 hard winter wheat. A large amount of business comes to the New York "future" market from other exchanges, owing to the system of "spreading "-buying or selling in New York, and doing the opposite on some other exchange. Wheat is usually bought both by grade and sample, except Duluth wheat, which is usually bought on Duluth certificate of inspection. The receipts of wheat in 1908 were $27,797,800$ bushels, and the amount shipped was $27,035,634$ bushels.

Minneapolis is the greatest primary wheat market, and 
milling centre in the world. Its importance is shown by the fact that it received in 1908, 91,739,000 bushels of wheat. It is the market for the hard spring-wheat district. A market here was the natural result of the fertile wheat lands to the west and south-west of it, of the excellent railway and water facilities with which it is provided, and of the aid given to the local milling industry by the water power, provided by the Falls of St. Anthony. As an export market Minneapolis is of minor importance ; most of its wheat goes to the local flour mills, and its quotations of prices are therefore unimportant factors in European markets. Its "contract" grades are No. 1 Northern wheat, and No. 2 Northern wheat at a discount of $3 \frac{1}{2}$ cents per bushel below the price of No. 1 Northern. A large amount of "hedging" is done on the Minneapolis Exchange. Statistics show the marvellous growth of wheat receipts at Minneapolis ; prior to $188110,000,000$ bushels was the maximum amount per year; now its annual receipt is about $90,000,000$ bushels.

Duluth stands the farthest north of the leading United States primary markets. It is the most westerly point of receipts of the hard spring wheat, of which Minnesota has always been one of the chief sources. Duluth is, therefore, a prominent port of accumulation for grain intended for eastward shipment by lake. Being near the sources of supply, and at the head of the longest eastward voyage. it has a commercial advantage in grain distribution which no other port in the United States, except its twin city Superior, enjoys. The shipments from Canada are likewise accumulated here during the winter months, and are held in storage, until the opening of lake navigation in 
the spring. Canadian grain destined for export is received and stored under bond, pending exportation, to be forwarded under special transit manifests, within the period specified in the bond. Duluth is a very important export market. Wheat is sold directly to European importers, and Duluth quotations are important on the European markets. Besides being a market for hard spring wheats, it has now a large export trade in the Durum wheats of the North-West. Little "hedging " is done in this market; Minneapolis overshadows it. The "contract" grade of wheat for spring wheat is No. 1 Northern, but No. 2 Northern is deliverable at seller's option at a penalty of five cents per bushel. For Durum wheat the "contract" grade is No. 1, with No. 2 deliverable at seller's option at a penalty of five cents per bushel. Duluth grades are higher than those on the Atlantic seaboard, and European importers usually ask for guaranteed shipment. The receipts of wheat at Duluth-Superior in 1908 were 53,890,816 bushels.

Kansas City is the hard winter-wheat market, and as a milling centre it ranks next to Minneapolis. It became the natural centre for the hard winter-wheat region on account of its excellent railway facilities, and its position at the confluence of the Kansas River with the Missouri. Kansas ships wheat to St. Louis, Chicago, Toledo, and Minneapolis. As an export market it is of some importance, sending wheat to Europe by way of the Gulf of Mexico. Its cash wheat market is more important than its "future" wheat market. Its receipts of wheat in 1908 were 40,131,300 bushels. The "contract" grade in the market is No. 2 Hard Winter wheat of not less than 
59 pounds per bushel, but No. 2 Red may be delivered at the seller's option.

St. Louis holds a high position among the great primary marts of the United States. It owes its importance largely to the fact that it is situated a little below the confluence of the Missouri and Mississippi, and, since the construction of the Erie Canal, it has had the advantage of two great waterways in communication with the ocean, and more or less competing with one another, and affecting the competition of railways running in different directions. The nearest port for wheat is Galveston, from which much of it is shipped. When the railways running south to Galveston become congested, and are consequently disposed to charge too high rates, the merchants are able to apply for rates by rail or river to New Orleans, by rail to Baltimore or other eastern port, or part rail and part water route down the Erie Canal to New York. St. Louis could be reached by river, many years before it could be reached overland. In 1908, St. Louis received $18,246,325$ bushels of wheat, coming from the great grain. growing states of Illinois, Missouri, Kansas, Iowa, Nebraska, Minnesota, and the Dakotas. A business of marked importance is done at St. Louis in the exportation of wheat to many foreign countries. As a soft winter-wheat market, St. Louis holds first place, and controls the marketing of almost the entire production of that class of wheat. St. Louis has lately become a semi-hard winter-wheat market also, and its milling industry is important. The "contract" grades of wheat are No. 1 Red Winter wheat, No. 2 Red Winter wheat; No. 1 Hard Winter wheat, and No. 2 Hard Winter wheat 
may be delivered on contracts, at three cents per bushel under the contract price.

Winnipeg is the great wheat market of Canada. Its position at the confluence of two navigable rivers-the Red River, which flows northwards from the United States through one of the richest wheat valleys in the world, and the Assiniboine, which comes from the westtogether with the convergence of railways on it, has made Winnipeg the centre of trade for the great wheat fields of the West. It is in one respect peculiar as a market, for its bases of supplies are the great terminal elevators at Fort William and Port Arthur, and wheat sold for future delivery means delivery from the Fort William and Port Arthur elevators, 420 miles east of Winnipeg. Winnipeg is a great inspecting centre, and much of the wheat of North-West Canada is inspected there. The receipts of wheat at Fort William and Port Arthur in 1908 were $40,689,868$ bushels. The "contract" grades are No. 1 Hard at one cent premium over No. 1 Northern, with the privilege of delivering No. 2 Northern on contract at a three-cent discount under No. 1 Northern, and the privilege of delivering No. 3 Northern on contracts at ten cents discount under No. 1 Northern. Winnipeg is developing into an important "future market." Though a large amount of the wheat of North-West Canada is sold for export, Winnipeg is not an export market. It is true that some wheat is sold at Winnipeg for direct export, but the export trade is carried on chiefly through Chicago and Montreal houses. Winnipeg is bound to become still more important as a market, and possibly the future may see it attain the highest position as a wheat market. 


\section{CHAPTER $\mathrm{X}$}

\section{PRICE OF WHEAT}

UNDER normal conditions, the price of wheat is determined by the world conditions of supply and demand pertaining to bread-products. Modern factors governing price, however, are so many and complex that normal conditions never exist in the world's great wheat markets. In the local markets, removed by lack of transport facilities from the influence of the world factors of price, normal conditions may exist, but sooner or later international conditions will exert their influence. If the farmer sold his wheat to the miller, and if there were no elevators, no exchanges, and no trading in futures, then the price of wheat would easily be determined-supply and demand would control it.

The value of wheat and its price are not the same thing, though they may sometimes be equal. There are times when it is evident that the price of wheat is either above or below its real value. For example, the best kinds of wheat may be plentiful, and consequently cheap, while the poorest sorts, which the miller requires for mixing with the better sorts, owing to shortage of supply, may be relatively dear.

Variations in supply and demand cause direct variations in price, and price reacts on demand and supply, 
causing variations. The control, exercised by price on demand and supply, is comparatively slow in operation, but the tendency is permanent.

There are many causes resulting in variation in the supply of wheat: (1) Departures from the normal climate (especially rainfall) in the wheat regions, causing shortage or increase of the crop ; (2) the increase of wheat acreage in new districts ; $(3)$ the decrease in wheat acreage owing to the growth of more profitable crops in certain regionse.g., fruit in California, and alfalfa in Argentina ; (4) the variations in acreage resulting as a reaction to variations in price (it is noticeable that when the price of wheat has been higher than the normal in a certain year, the next year usually sees an increased acreage under wheat in the highest-developed commercial wheat regions, and when the price has declined below the normal in a certain year, the next year usually witnesses a decrease in the acreage under wheat); (5) the facilities for and hindrances to transportation; (6) the establishment of tariffs hindering trade, or their abolition increasing trade between countries-e.g., consider the probable effect on Canada's wheat acreage if the United States tariff on wheat should be abrogated ; 7 ) the extent of the competition in a given market or markets at a given time; (8) the new systems of agriculture extending the wheat regions-e.g., "dryfarming "; (9) the failure or partial failure of the wheat crop in certain regions, due to either climatic conditions, a scourge of insects, or a disease; (10) the degree of fertility of the soil ; and (11) an improvement in the methods of wheat culture.

Causes affecting a variation in demand are-(1) The 
raising of the standard of living in rye-eating and riceeating countries ; (2) the raising of the standard of living in wheat-eating countries, resulting in less wheat and more flesh meat being consumed; (3) war, causing a decrease of population, and possibly checking the demand of an importing country ; and (4) the increase of population.

Supply and demand are always seeking equilibrium. When the price of wheat makes production unprofitable, the tendency is for capital to engage in the production of other cereals or products; but when the price of wheat, rises too high, the substitutes for wheat are used to some extent. The demand is thus lessened, and production decreases. Generally, the value of wheat to the consumer must cover the cost of production and the expenses of its distribution, and this cost determines the lowest normal limit of price. The highest normal limit of price is plainly the value of the wheat to the consumer. The cost of production rarely enters into price unless the price declines to a very low figure. When wheat is above seventy cents per bushel in America, the cost of production rarely becomes a market factor.

Transportation and telegraph and postal facilities are important factors nowadays in the determination of the price of wheat, since in all important markets world prices exist. Prices formerly awaited for weeks are now known on the same day in all the great centres. A favourable situation is no longer very advantageous in the determination of price, for all markets of importance are simultaneously affected by changes either in supply or demand. Improvements in transportation, resulting in 
quicker transit and lower freight rates, tend to lower the cost, and increase the amount produced. The ideal conditions of price in any two markets should be that the price in them should only differ by the excess of transportation and commercial charges in one over the other.

The countries of the world are to-day either exporting or importing wheat countries, if wheat is consumed in them. Importing countries largely fix the price of wheat in the exporting countries. The United Kingdom, with its large importations of wheat, holds a commanding position in fixing the price of American wheat. Under normal conditions, this price must always be higher than that which America could fix for itself, and consequently a benefit accrues to America. Legislation becomes a factor in the price of wheat, when duties are levied on wheat. At the present time, many important wheatimporting countries levy a high duty on grain, and wheat prices are thereby increased. The absence of duties in the past on wheat entering the United Kingdom made the price of wheat in her boundaries approach nearly to the level of the theoretical normal world price.

Though speculation is sometimes the great cause of changing prices, economists have clearly shown that its tendency is to steady prices. It is only possible for the great grain interests to permanently fix prices in the large world markets by possessing an approximately accurate and complete knowledge of the conditions of supply and demand, and fixing the price in accordance with what it should normally be under the existing conditions. A peculiar characteristic of speculation is that 
its first influence on price is usually upwards. A decline, however, always follows after an artificial demand. "Short selling" on the exchanges has probably little, if any, effect on the average price of wheat, since it is equalized by "long buying." Big advances in price are caused generally by crop failures or combination, or by both together. Big declines in price are the reactions from speculative advances, or they are the result of the passing from an old crop year of high prices to a new harvest of abundant crops.

An important factor, having its influence on the price of wheat, is that of the next crop of wheat, and its influence is felt a long way ahead in either raising or lowering the price. When the question arises whether surplus grain should be carried over from one commercial year to another, the unknown conditions of the succeeding crop cause great doubt, lest the price should fall still lower; but the advantages of holding back the surplus in expectation of a better price within the commercial year may be considerable, while the risk of thus holding over the grain is very much smaller, since the fluctuations of price within the commercial year are smaller than from one year to another. A calculation, made by Dr. I. M. Rubinow, of the United States Bureau of Statistics, proves this statement. Normally, the British price should be higher than that in New York, and the greater this excess the more profitable shipments of wheat from the United States to Great Britain. For the purpose of his calculation, the excess of the annual British price over the annual New York price, as well as the excess of the average monthly British price over the New York monthly price, 
was determined; and the monthly exports from the United States each year were classified according to whether the excess of the British monthly price over the New York monthly price was higher than the excess of the annual price or lower, the presumption being that in those months when that difference of price was greater, the British market was more advantageous than during those months when the difference was lower. The exports for both groups of months were added, and the arerage monthly exports for each group of months was obtained. The results show that, in seventeen out of twenty-one years, the average monthly exports were greater, when the difference of price was greater. During only four years this rule did not prevail. Of these, the difference as between the arerage exports during the month of either group is very small indeed in 1889 to 1890 , and in 1894 to 1895 , while the total exports in 1904 to 1905 were too small to be of great significance. There remains only one year, during which the exports were materially greater in those months, when the price was less favourable. That was the year 1897 to 1898, when a "corner" in wheat took place. The extremely high New York quotations in April and May, 1898, were purely speculative, and British prices only partially followed this rise, and were lower than in New York.

Relation between monthly exports of wheat from the United States and the excess of the arerage price of native wheat in England and Wales over the average New York price of No. 2 Red Winter wheat, 1884-85 to 1904-05: 


\begin{tabular}{|c|c|c|c|c|}
\hline 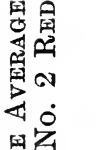 & 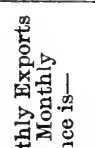 & 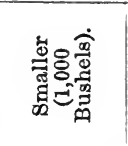 & 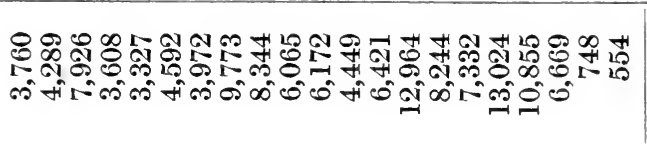 & $\underset{\substack{\infty \\
+\infty}}{\infty}$ \\
\hline 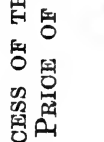 & 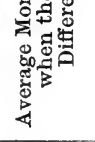 & 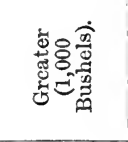 & 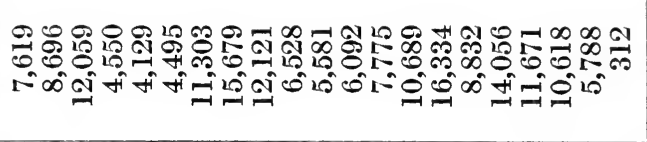 & 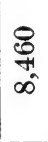 \\
\hline 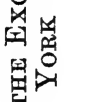 & 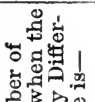 & 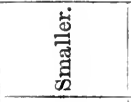 & 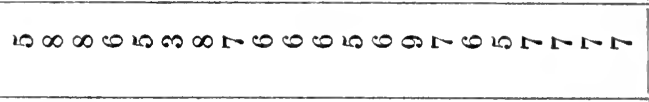 & 苞 \\
\hline 爷量 & 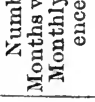 & 离 & NTHCONOA & $\stackrel{\infty}{=1}$ \\
\hline 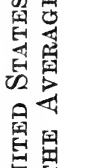 & 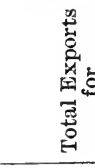 & 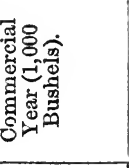 & 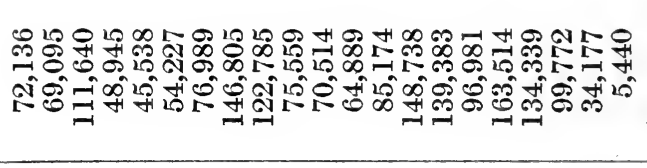 & $\begin{array}{l}\text { +1 } \\
0 \\
0 \\
\infty \\
\infty \\
-1\end{array}$ \\
\hline 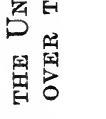 & & 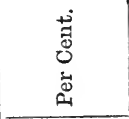 & 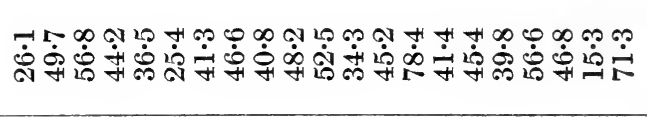 & $\stackrel{4}{4}$ \\
\hline 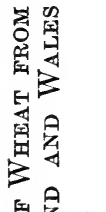 & 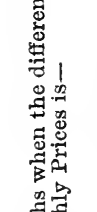 & 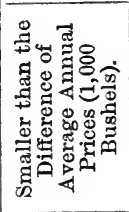 & 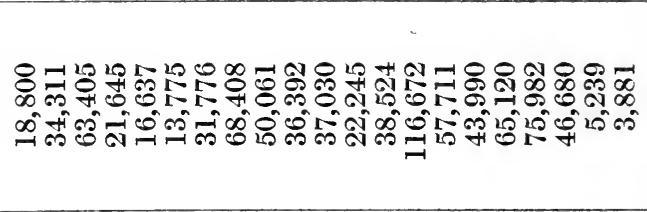 & $\begin{array}{l}+1 \\
\infty \\
\infty \\
\infty \\
\infty \\
\infty\end{array}$ \\
\hline 至过 & 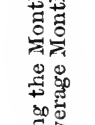 & 节 & 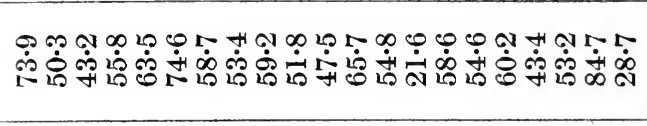 & ஜ் \\
\hline 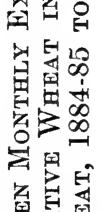 & 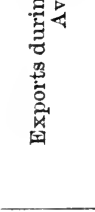 & 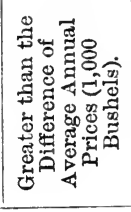 & 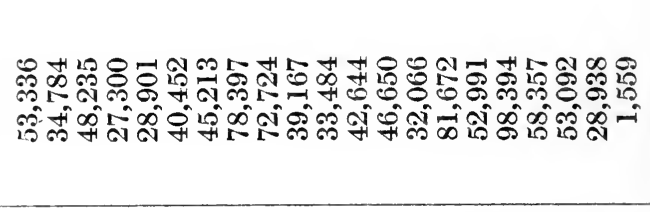 & कृ \\
\hline 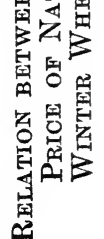 & \multicolumn{2}{|c|}{ 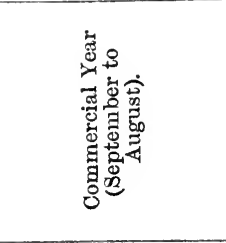 } & 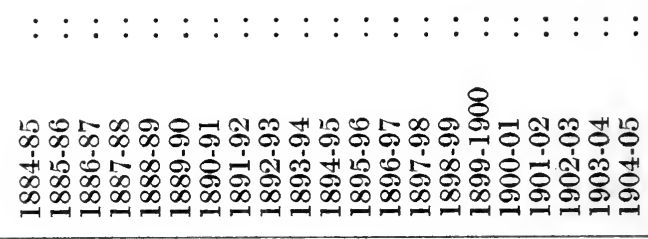 & : \\
\hline
\end{tabular}


Not only were the average monthly shipments greater, but, in seventeen years out of the twenty-one, a much larger share of the annual exports from the United States was sold under these more favourable circumstances. The average monthly exports during the more favourable months were about 30 per cent. higher than at other times.

The "visible supply" of wheat-that is, the wheat stored in elevators, or in the farmers' hands, or at the seaboard, which has not found a market, for it must be remembered that the grain consumed during the entire year is harvested in a few months-has its influence on price in delaying and sometimes lessening demand, and thus decreasing price. Argentina is a great disturber of wheat prices, since her surplus wheat is poured into the world markets about midway between North American harvests.

The effects of concentrated shipments upon price are unmistakable. In New York the average monthly price during August to October (1884 to 1906), the months of heaviest shipments, was 84.9 cents per bushel, as against 88.7 cents for the remainder of the year. In general, the average price varies inversely with the volume of exports. The depressing effect of excessive shipments upon the price at the export port, in view of the sensitiveness of the modern world market, is in itself sufficient guarantee that these exports will have a depressing influence upon the world price. The lack of storage facilities in Argentina leads to excessive shipments and a lowering of price. Even in the United States the conditions are far from ideal, since much the larger part of the crop is marketed 
within one half of the year-August to January. For the period 1884 to 1906,59 per cent. was marketed during the period August to January, and 41 per cent. during the other six months.

Price is the instrument by means of which an equilibrium tends to be established between supply and demand. Itself the result of past conditions of production, it frequently influences the conditions of future production. To be economically advantageous, production should constantly adjust itself to price conditions. In wheat production, this effect of price expresses itself, or should express itself, in oscillations of acreage. An attempt has been made in the accompanying diagrams to show the influence of wheat prices upon wheat acreage in the United States and Argentina. It will be seen that the United States wheat acreage shows a tendency to fluctuate in harmony with preceding prices; that an increase in price is likely to produce an extension of acreage much sooner than a depression of price a corresponding reduction of acreage ; but that, nevertheless, a decided check upon acreage has followed seasons of depressed price. The same may be said of Canada. It must be remembered, however, that the wheat acreage is yearly greatly increasing in North-West Canada, but that a higher price than the average increases the normally increasing acreage, and a lower price than the average decreases the normally increasing acreage. Wheat acreage in Argentina grows almost without regard to the price of the grain at a fairly uniform rate, whether prices are high or low. Such a condition as this is also found in Russia, another poorly developed country. 


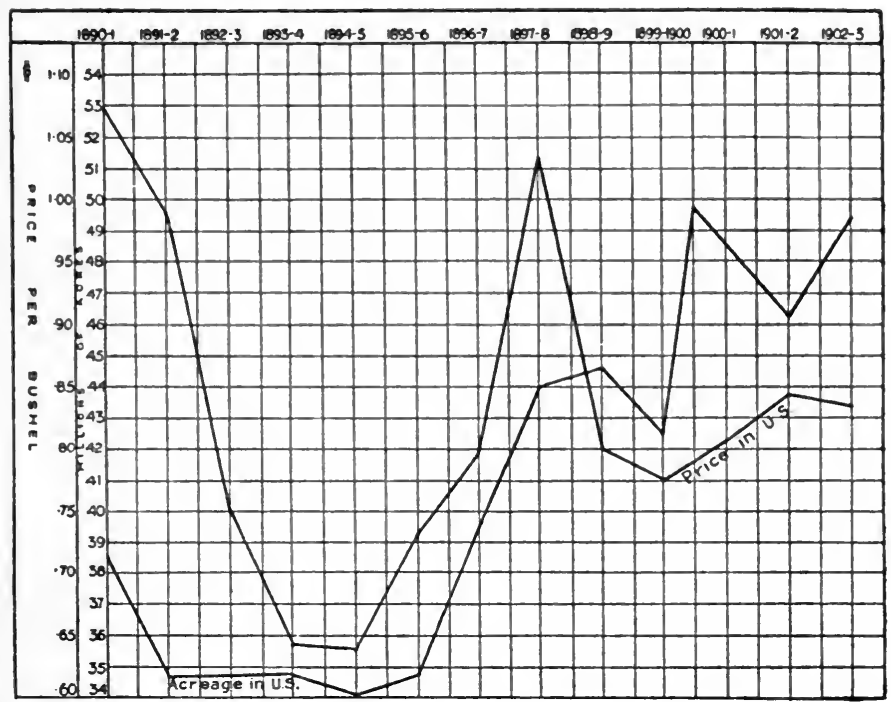

Fig. 22.-United States : Preceding Annual Price of Wheat and its Relation to Wheat-Acreage.

Year ending August 31.

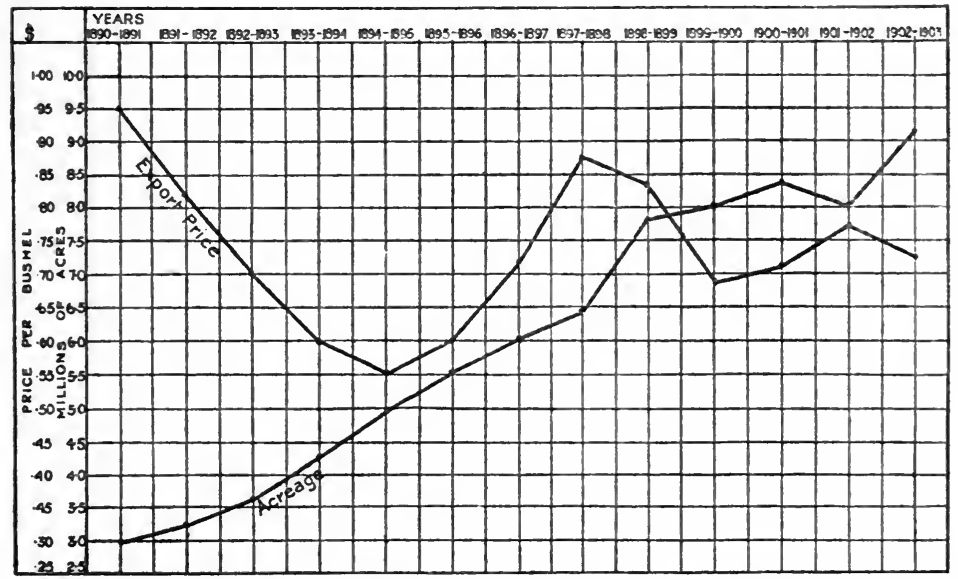

Fig. 23.-Argentina : Preceding Annual Price of Wheat and its Relation to Wheat.Acreage. 
It has been asserted that the United States will soon become an importer of wheat, owing to her rapidly increasing population. If the import duty of twenty-five cents per bushel should be abrogated, as now seems probable, then in short-crop years she may become an important importer. If the duty remains, however, it will have the effect of raising the price of wheat in the United States, as she approaches the dividing-line between exports and imports; and this will have a tendency to increase the wheat acreage of the United States.

It is necessary to discuss the relation of the price of wheat to the productivity of wheat. The farmer has to consider the suitability of his land for different uses. It is frequently not advisable to rely solely upon wheat, for the risk of failure is often great. He must in many cases calculate the differential advantages or disadvantages of growing wheat with those of a growth of varied crops and mixed farming, and here consideration must be given to the amount of new capital and labour required in a change of crops or farming, and his own personal aptitude for varied cultivation. If the whole of a locality were suitable for varied cultivation, and the price of wheat rose, and other conditions were favourable, then the tendency would be for wheat acreage to increase in that locality. In the wheat districts removed from railway communication, and to which immigrants are streaming, a good price for wheat and beef may be obtained, and hence attention is paid to their production. The oscillations between wheat production and mixed farming depend to a great extent on the export price of wheat. When the price of wheat has been low in a certain year, the next year has 
usually seen an increase in mixed farming. The question of intensive farming of wheat is largly centred in the price of wheat. The Law of Decreasing Returns has made its influence felt in the older wheat districts of America, and much land formerly under wheat is now used for other purposes. The wheat farmer in these old districts must estimate whether intensive cultivation of wheat will pay him, and local prices will often govern his actions. Intensive farming to any appreciable extent is rarely found in a new country till all the fertile land that is accessible has been exploited. The cost of cultivating poor land is usually as high as in the case of rich land, and sometimes higher, while the return is not nearly so good. Doubtless a time will come, when the question of whether intensive cultivation in the older wheat districts will not be more advantageous than the extensive cultivation of the poor tracts in the newer wheat districts. The price of wheat will largely settle this question, and freight rates and nearness to markets will be two important factors.

Wheat prices in the world markets are becoming more uniform, and this uniformity tends to decrease the amount of business done upon the grain exchanges. With the further concentration of commercial wheat interests, the steadiness of prices will be increased. As population increases in America, the local consumption of wheat will increase, and local markets will become more important, and speculation will then play a lesser part in the fixation of wheat prices. Steadiness of prices will tend to increase wheat production.

The backwardness of storage facilities in Argentina, the comparatively high transportation charges, the almost 
complete ignorance of the majority of Argentine wheat producers of world conditions of wheat prices, and the poor marketing system, result in the wheat-growers obtaining a lower price than the producer in North America, who labours under well-developed conditions governing prices. Better price conditions will, however, exist in Argentina, as the development of the country progresses. 


\section{CHAPTER XI}

ACREAGE, PRODUCTION, AND EXPORTATION

IN considering the wheat acreage, production, and exportation of America, the following order will be taken : (1) Canada, (2) the United States, (3) Argentina, and (4) the other countries of America.

\section{Canada.}

Canada has, perhaps, the brightest future wheat prospects of any American country, and for her population she has shown marvellous increase in the production of wheat during the last few years. Since 1900, development has been very rapid in Western Canada. In that year, 1,870,260 acres were under wheat in North-West Canada, whereas in 1910 the acreage had risen to $8,395,400$ -an increase of nearly 350 per cent. Western Canada had the land and the climate before 1900, but remained only partially developed, owing to the fact that cheap lands were not then exhausted in the United States, and that the climate of the North-West was not appreciated. Immigration, and that largely from the United States, brought prosperity to the Saskatchewan Valley. Settlement of new lands in Western Canada has largely been by farmers from the United States, though much migration has 
taken place from Eastern Canada. European immigrants are now streaming into the prairie provinces. The Canadian farmers, and those from Illinois, Iowa, Minnesota, and the Dakotas have money, energy, and experience, and are able to do in one year as much as the pioneers of the Western United States did in five. Migration across the border from the South still plays its important part in the North-West. The immigration from the United States was 9,119 settlers in 1898, while for the twelve months ending March, 1910, it had risen to 103,798. The Commissioner of Emigration estimates the capital per head at $£ 220$. One hundred thousand settlers, mainly going to wheat farms, and bringing in capital and experience, must mean an immediate and large expansion of Canadian wheat territory, and an annual production per capita far exceeding anything that the United States has known. The greatest crop ever raised on unfertilized land is credited to Western Canada in 1901, when $62,820,282$ bushels of wheat were raised on 2,516,532 acres-an average of about 25 bushels per acre.*

There are several points of interest in the table on p. 243. It is clear that this region has been making history for itself. Throughout the whole region there has been an almost steady rise in wheat acreage, and in production also, if climatic factors are borne in mind. A very striking feature is the vast progress made in Saskatchewan, and to a lesser extent in Alberta, since 1904. Alberta's winterwheat region is somewhat limited, but may become a

* The statistics in this chapter are based on official and commercial estimates. Of necessity, they are only approximately correct. 


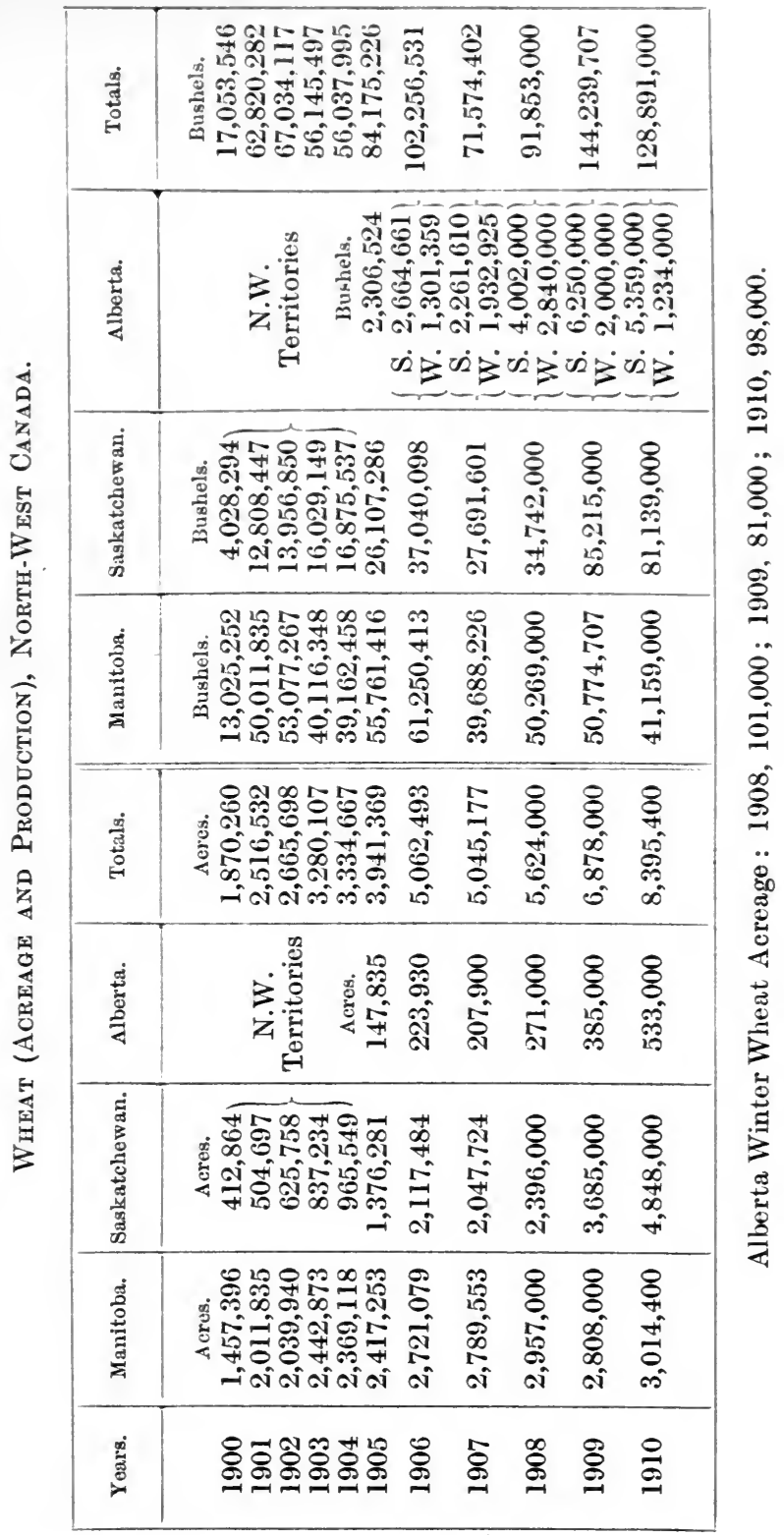


factor of more importance in the future. It is on this North-Western region that Canada must rely for her position as a wheat producer. The northern extensions of wheat in Western Canada are of great importance, and will assume greater significance as more knowledge is gained of the climatic and soil factors of the region. Dr. William Saunders states that during 1908 experiments were carried on in the Peace River district at Fort Vermilion, 380 miles north of Edmonton, where the crop amounted to 35,000 bushels, and adds the important statement that "there seem to be no climatic differences there, which are more difficult to overcome, than in the immediate vicinity of Edmonton."

Wheat (Acreage and Production), Eastern Canada.

Totals for the Five Provinces.

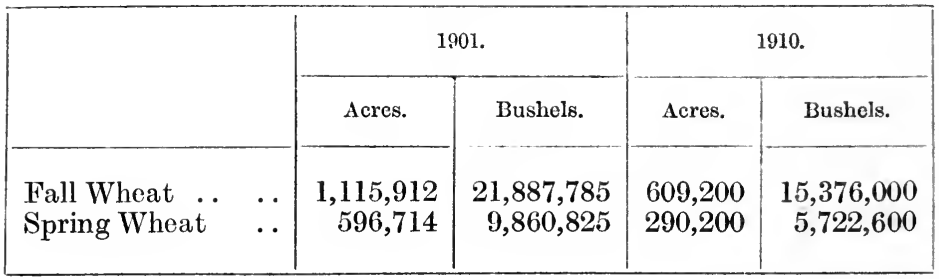

Acreage.

\begin{tabular}{|c|c|c|c|c|c|c|}
\hline Years. & Ontario. & Quebec. & $\begin{array}{c}\text { New } \\
\text { Brunswick. }\end{array}$ & $\begin{array}{c}\text { Prince } \\
\text { Edward } \\
\text { Island. }\end{array}$ & $\begin{array}{c}\text { Nova } \\
\text { Scotia. }\end{array}$ & Totals. \\
\hline 1907 & 820,678 & 107,698 & 20,601 & 35,847 & 20,419 & $1,005,243$ \\
1908 & 821,766 & 105,500 & 17,579 & 27,600 & 20,600 & 993,045 \\
1909 & 798,536 & 100,500 & 14,447 & 26,100 & 20,600 & 960,183 \\
1910 & 729,500 & 99,400 & 19,500 & 30,000 & 21,000 & 899,400 \\
\hline
\end{tabular}


Production in Bushels.

\begin{tabular}{|c|c|c|c|c|c|c|}
\hline Years. & Ontario. & Quebec. & $\begin{array}{l}\text { New } \\
\text { Brunswick. }\end{array}$ & $\begin{array}{l}\text { Prince } \\
\text { Edward } \\
\text { Island. }\end{array}$ & $\begin{array}{l}\text { Nova } \\
\text { Scotia. }\end{array}$ & Totals. \\
\hline 1907 & $\left\{\begin{array}{r}\text { W. } 15,545,491 \\
\text { S. } 2,473,651\end{array}\right.$ & $\left.\begin{array}{r}47,563 \\
1,692,164\end{array}\right\}$ & 410,714 & 582,450 & 336,318 & $21,088,351$ \\
\hline 1908 & $\left\{\begin{array}{r}\text { WV. } 16,430,476 \\
\text { S. } 2,197,716\end{array}\right\}$ & $1,424,000$ & 292,491 & 425,000 & 412,000 & $21,181,683$ \\
\hline 1909 & $\left\{\begin{array}{r}\text { W. } 15,967,653 \\
\text { S. } 2,223,567\end{array}\right\}$ & $1,679,000$ & 268,079 & 537,000 & 412,000 & $21,087,299$ \\
\hline 1910 & $\left\{\begin{array}{r}\text { WV. } 15,376,000 \\
\text { S. } 2,429,000\end{array}\right\}$ & $1,827,000$ & 371,000 & 615,600 & 480,000 & $21,098,600$ \\
\hline
\end{tabular}

Eastern Canada shows a great decrease in wheat production and acreage since 1900, and this decrease has been fairly steady. The acreage cannot be expected to expand, till the virgin tracts in the West have all been taken up; then the problem to be dealt with will be whether intensive cultivation in the East can compete with extensive and intensive cultivation in the West, and freight rates and nearness to markets will be two of the most important factors in deciding the question.

British Columbia is now of minor importance in wheat production, but many factors suggest a more hopeful future. Among these may be mentioned the extension of railways to the Pacific Coast, the suitability of its soil and climate in many parts to the growth of soft wheats, and the introduction of "dry-farming" methods. The present annual wheat production is about 500,000 bushels.

Canada has made vast strides since 1871 , but the most notable increase dates from 1900. Her average crop now is more than double of that in 1900 , and there are many signs that tend to show that her production will continue materially to increase, but this increase will for many years be limited to the prairie provinces. There will, 
possibly, come a time, when wheat acreage and production will increase in the Eastern provinces.

\section{Total Wheat Production of Canada, 1900-1910.}

\begin{tabular}{|c|c|c|c|c|c|}
\hline \\
\hline & $\begin{array}{c}\text { Bushels. } \\
47,867,917\end{array}$ \\
\hline 1901 & .. & .. & .. & .. & \\
\hline 1902 & .. & .. & .. & .. & $93,769,450$ \\
\hline 1903 & .. & $\therefore$ & .. & $\because$. & $78,495,202$ \\
\hline 1904 & .. & $\therefore$ & $\therefore$ & $\therefore$ & $69,029,266$ \\
\hline 1905 & .. & .. & .. & .. & $109,097,000$ \\
\hline 1906 & .. & .. & .. & .. & $127,772,000$ \\
\hline 1907 & .. & .. & .. & $\ldots$ & $93,113,000$ \\
\hline 1908 & .. & .. & .. & .. & $113,485,000$ \\
\hline 1909 & .. & .. & .. & .. & $165,827,000$ \\
\hline 1910 & .. & .. & .. & .. & $150,439,600$ \\
\hline \multicolumn{6}{|c|}{ Acreage. } \\
\hline 908 & .. & & .. & .. & $6,610,300$ \\
\hline & .. & & .. & .. & $7,750,400$ \\
\hline 191 & . & & . & $\ldots$ & $9,294,800$ \\
\hline
\end{tabular}

In a comparatively new wheat country like Canada, the amount of wheat exported is a high percentage of the production, and it is to this export of wheat that Canadian farmers look for the disposal of a great part of their crop. In comparison with the wheat exports of the United States and Argentina, that of Canada lags behind, though in proportion to her population and wheat acreage the wheat export is large.

It will be noticed that Canada's best customer is the United Kingdom, and that the United States buys an important quantity in some years. The other importing countries are those of Western Europe, and, to a slight extent, those of Eastern Asia. The wheat exports show great fluctuations, but will become more stable as the wheat territory enlarges. 


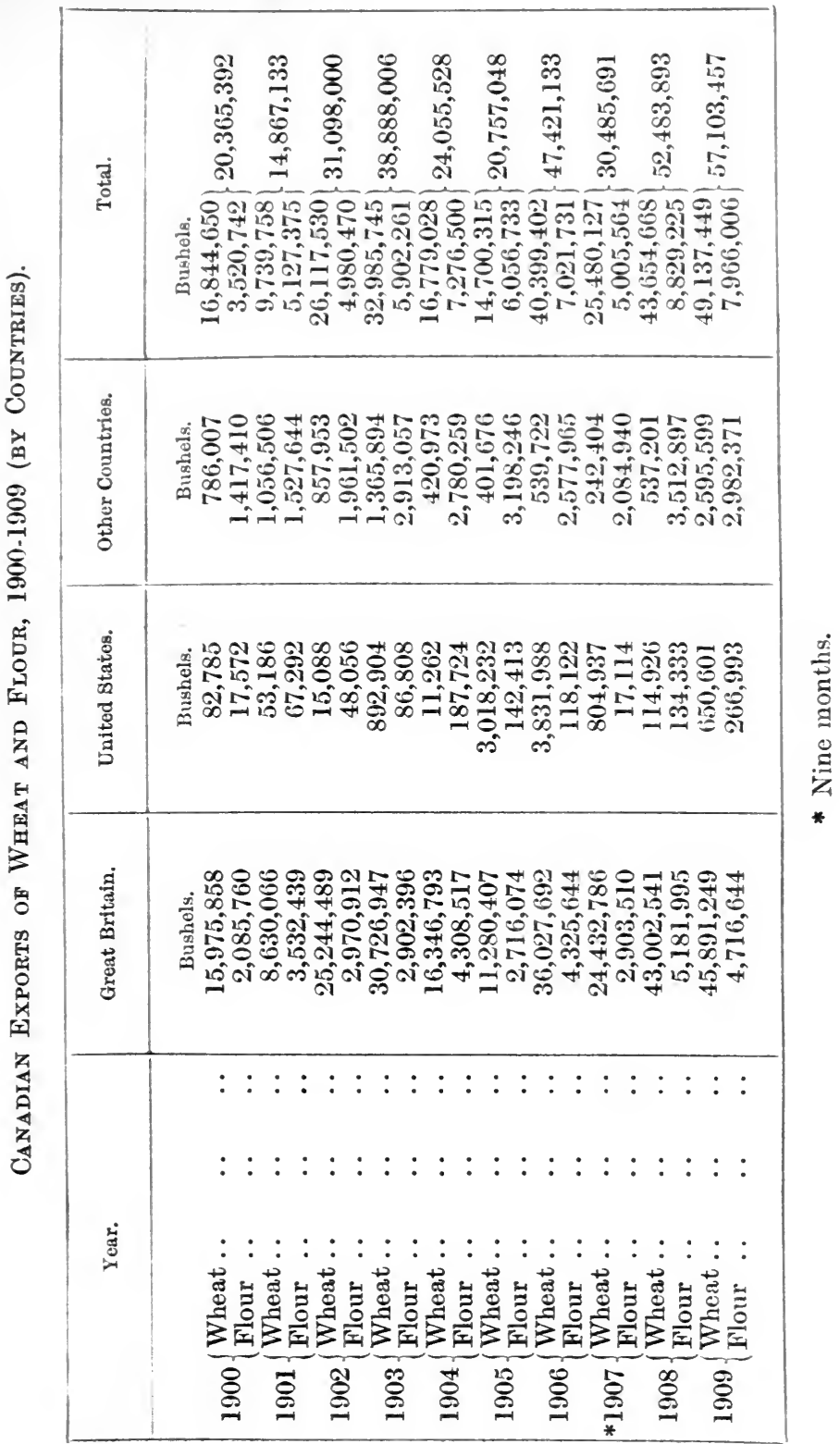




\section{The United States.}

The United States shows an older development of wheat lands than Canada does, and she has now, perhaps, owing to the pressure of population, to turn her attention to intensive cultivation. The importance of the United States lies not only in the amount of wheat exported, but also in the total production of wheat. In considering her acreage and production, the various states will be taken in decades, commencing at 1866, and thus some idea of the future of wheat in the United States may be obtained.

From 1866 to 1875 the wheat acreage in the United States varied between $15,000,000$ and 26,000,000, and from the beginning to the end of the decade the rise was consistent. In the following ten years the range was from $26,000,000$ to $39,000,000$ acres, giving on the whole a steady increase, but showing 34,000,000 acres in 1885 . The period from 1886 to 1895 ranged from $34,000,000$ to nearly $40,000,000$ acres, with smaller acreage in the later years. From 1896 to 1905 the minimum was $34,000,000$, and the maximum $49,000,000$ acres, the higher figure occurring in 1901 and 1903. The average acreage for the period 1906-1910 was 45,000,000 acres, the acreage in 1910 being $49,000,000$. The high average for the last ten years is a significant element, but there is an indication of a tendency to a stationary position-at least, in relation to world acreage.

As regards production, the total for 1866 in the United States was about $152,000,000$ bushels. Notable years were 1867, when production exceeded $200,000,000$ bushels ; 1873 , when $308,000,000$ bushels were raised; 1878 , when 
the $420,000,000$ bushel mark was reached; and 1882, when 504,000,000 bushels were produced. Fluctuations occurred in the following years, and production in any one year in the period 1883 to 1890 only once reached the $500,000,000$ bushels total. The year 1891, however, showed $611,000,000$, and $1898675,000,000$ bushels. The maximum crop was reaped in 1901, with $748,000,000$ bushels.

$$
\begin{aligned}
& \text { Wheat Acreage in the United States for the }
\end{aligned}
$$

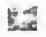

\begin{tabular}{|c|c|c|c|c|c|c|}
\hline & & & & & \multirow{2}{*}{\multicolumn{2}{|c|}{ Millions of Bus }} \\
\hline 1866 & $\cdots$ & $\cdots$ & - & $\cdots$ & .. & \\
\hline 1876 & .. & $\ldots$ & $\ldots$ & $\ldots$ & .. & $289 \cdot 357$ \\
\hline 1886 & .. & $\ldots$ & .. & $\ldots$ & .. & $457 \cdot 218$ \\
\hline 1896 & .. & $\ldots$ & .. & .. & .. & $427 \cdot 684$ \\
\hline 1906 & .. & . & .. & .. & .. & $735 \cdot 261$ \\
\hline 1907 & . & $\cdots$ & .. & $\cdots$ & .. & $634 \cdot 087$ \\
\hline 1908 & .. & .. & .. & $\cdots$ & .. & $664 \cdot 602$ \\
\hline 1909 & .. & . & .. & . & .. & $737 \cdot 189$ \\
\hline 1910 & $\cdots$ & . & .. & . & . & $695 \cdot 443$ \\
\hline \multicolumn{7}{|c|}{ Average. } \\
\hline 1871 & 380 & $\cdots$ & . & $\cdots$ & .. & $338 \cdot 319$ \\
\hline 18 & 890 & $\cdots$ & .. & . & .. & $439 \cdot 767$ \\
\hline 189 & 900 & . & .. & .. & .. & $515 \cdot 375$ \\
\hline 190 & 910 & .. & .. & .. & .. & $676 \cdot 831$ \\
\hline
\end{tabular}

$$
\begin{aligned}
& \begin{array}{lllll}
\text {. } & \text {. } & \text {. } & \text {. } & 27.019
\end{array} \\
& \begin{array}{lllll}
\text {. } & \text {. } & \text {. } & \text {. } & 37.090
\end{array} \\
& \begin{array}{lllll}
\text {. } & \text {. } & \ldots & \ldots & 38.726
\end{array}
\end{aligned}
$$

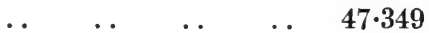

Wheat Production of the United States for the Years MENTIONED. 
Considering states singly, some remarkable fluctuations are noticeable. Kansas had a crop of $99,000,000$ bushels in 1901, and $62,000,000$ in 1910. Minnesota dropped from $78,000,000$ bushels in 1898 to $51,000,000$ in 1900 , and leaped to $94,000,000$ in 1910. South Dakota in the same years had crops of $37,000,000,20,000,000$, and $47,000,000$ bushels. The wide distribution of wheat, however, makes the general total for the whole country much more stable.

With reference to the production of wheat from East to West in the United States, the following four regions will be considered : (1) The Middle Atlantic States from New York to Virginia, including especially Maryland and Pennsylvania; (2) the five states of the old North-West, lying between the Ohio River and the Great Lakes; (3) seven states west of the Mississippi River, including Missouri and Kansas on the south, and Minnesota and North Dakota on the north, the wheat belt extending on the west to the arid parts of the Great Plains; and (4) the Cordilleran region, including especially the Pacific Coast States.

The first of these regions was the centre of wheat production, from the time when wheat was fully established until improved means of communication, notably the Erie Canal, opened out the possibilities of the old NorthWest. In 1839, New York State produced over 12,000,000 bushels, and, in 1910, over 10,000,000 bushels. Her wheat acreage is now practically stationary, ranging between 400,000 and 450,000 acres. Pennsylvania shows a fairly steady rise from $13,000,000$ bushels in 1839 to $26,000,000$ in 1910. Maryland shows vast increase since 1897. Her crop in 1896 was $7,878,769$ bushels, while that of 1907 was nearly $15,000,000$ bushels. Virginia shows great 
fluctuations. Her crops in recent years have ranged from $3,500,000$ to $10,000,000$ bushels. West Virginia, North Carolina, and Georgia show fairly steady records of several million bushels. The New England States never ranked high as wheat raisers, and to-day Vermont and Maine are the only states in New England making a report on wheat.

Wheat acreage, in this region, shows a decline in the later period when compared with the earlier, but the recent increase in wheat acreage in Pennsylvania, Maryland, and the Carolinas suggests that land in the east is becoming advantageous again for wheat-growing, as the limits of the western virgin tracts are approached. It is certainly true that not enough wheat is grown to supply the local population, and that western wheat finds here a convenient market, but the production is a substantial one, and factors indicate that it is likely to increase.

The following table, giving the rank of the leading wheat states from the sixth to the twelfth census, illustrates well the swift western march of wheat:

\begin{tabular}{|c|c|c|c|c|c|c|c|}
\hline No. & 1839. & 1849. & 1859. & 1869. & 1879. & 1889. & 1899. \\
\hline 1 & Ohio & Pennsyl- & Illinois & Illinois & Illinois & Minnesota & Minnesota \\
\hline 2 & Pennsyl- & $\begin{array}{l}\text { Ohio } \\
\text { Ohia }\end{array}$ & Indiana & Iowa & Indiana & California & North \\
\hline 3 & New York & New York & Wisconsin & Ohio & Ohio & Illinois & Ohio \\
\hline 4 & Wyoming & Virginia & Ohio & Indiana & Michigan & Indiana & South \\
\hline 5 & & & Virginia & Wisconsin & Minnesota & Ohio & Kansas \\
\hline 6 & & & Pennsyl- & Pennsyl- & Iowa & Kansas & California \\
\hline 7 & & & & Minnesota & California & Missouri & \\
\hline
\end{tabular}

Production of the First State in Million Bushels.

\begin{tabular}{lllll|lllll}
1839 &.. &.. &.. & 16 & 1879 &.. &. &. & 44 \\
1849 &. &.. &. & 15 & 1889 &.. &. &. & 45 \\
1859 &.. &. &. & 23 & 1899 &.. &.. &.. & 68 \\
1869 &.. &.. &.. & 30 & & & & &
\end{tabular}


In 1839, while New York and Pennsylvania produced $12,000,000$ and $13,000,000$ bushels of wheat respectively, Ohio attained first place with 16,000,000 bushels, and the second region commenced its great record. In the fortyone years 1866-1906, Ohio produced 1,247,082,674 bushels -a yearly average of about $30,416,650$ bushels. In the twenty-year period 1867-1886, the total production was less by more than $100,000,000$ bushels than during the period 1887-1906. It is interesting to note that Ohio, in the twelfth census report crop of 1899, came first of all states in production per square mile, and that she has eight times exceeded $40,000,000$ bushels. Indiana, in 1860 , was second in production per square mile, first in 1870,1880 , and 1890 , and fourth in 1900 . Her total production for the period 1866-1906 approached closely that of Ohio, and she raised nearly $100,000,000$ bushels more in the last twenty-year period than the first. In 1910, she produced nearly $41,000,000$ bushels. The yearly average of Illinois for the period 1866-1906 was 28,301,273 bushels, and, unlike Ohio and Indiana, her second twentyyear period shows a decrease of about 100,000,000 bushels from the former, and this may largely be accounted for by her increased production of maize. The two Lake States, Michigan and Wisconsin, show a production of only about two-thirds of any of the three Ohio River States. Again, there is noticeable a decline in production in the second twenty-year period. In 1910, Michigan produced nearly $16,000,000$ bushels. Her maximum crop was $34,000,000$ bushels in 1898. Wisconsin, previous to 1884, often raised 20,000,000 bushels, but since 1892 she has only exceeded 10,000,000 bushels three times. Her crop of 
1910 was $3,659,000$ bushels. Soil exhaustion, insect enemies, and the practice of mixed farming largely account for her decline. With intelligent farming, both with regard to cultivation and the selection of seed, Wisconsin may in the future regain her lost prestige. Wheat acreage shows now a tendency to increase in Indiana, Illinois, Michigan, and Wisconsin.

The third group of states contains the well-known centre of wheat production in the United States. In 1867, Minnesota produced 10,000,000 bushels, and her production and acreage have steadily risen since then. From 1895 onwards, her crop has never been less than $46,000,000$, and has attained to $94,000,000$ bushels. Iowa shows a great decline in wheat acreage and production. About thirty years ago, her crop often exceeded $30,000,000$ bushels, but recent years show variations ranging from $8,000,000$ to $14,000,000$ bushels. Doubtless, the reason is to be found in the growth of maize and the live-stock industry. The average of Iowa for the period 1866-1906 was 21,432,000 bushels. Missouri shows a noticeable increase in wheat production and acreage in recent years. She raises crops of from 20,000,000 to $30,000,000$ bushels. Her maximum crop was $56,000,000$ bushels in 1902. The Missouri River Wheat StatesKansas, Nebraska, and the two Dakotas-represent one of the newest, and certainly one of the greatest developments of wheat in the United States. In 1882, Dakota territory (before division) reported $11,000,000$ bushels, whereas, since 1897, the production of North Dakota alone has but twice fallen below 51,000,000 bushels, and in 1909 she raised over $83,000,000$ bushels. Nebraska 
often produces over 40,000,000 bushels, and likewise South Dakota ; while Kansas' production is usually well over $60,000,000$ bushels. The totals for the three leading wheat states for 1897-1906 were as follows :

\begin{tabular}{lccccc} 
Minnesota &. &. & & & \multicolumn{1}{c}{ Bushels. } \\
North Dakota &. &.. &. &. & $685,129,558$ \\
Kansas .. &.. &.. &. &. & $533,777,567$ \\
Total for the three states &.. &.. & $687,901,805$ \\
\hline
\end{tabular}

Kansas shows a slight lead over Minnesota, and this is accounted for by several greater crops. Kansas' production, however, fluctuates more than that of Minnesota. Oklahoma and Texas extend the wheat belt along the Southern parts of the Prairies, and the Great Plains. Oklahoma, in 1894, produced 2,000,000 bushels, and she shows a fluctuating rise in production and acreage. Her crop in 1909 was $15,000,000$ bushels, and in 1910 was over 25,000,000. Texas is an older wheat state. She produced nearly $2,000,000$ bushels in 1866, and her present average is about $12,000,000$ bushels. While the great majority of these seven states show increase in wheat production and acreage during the last twelve years, Iowa shows a noticeable decrease. In 1899, $1,399,653$ acres were under wheat, whereas in 1910 this acreage had dwindled to 530,000 . There is no indication of much further increase in wheat acreage in the future in these states. Their hope of continued increase in wheat production would seem to depend on intensive cultivation.

The Cordilleran wheat region provides an older development in the three Pacific States, and a more recent pro- 
gress in the Rocky Mountain, plateaux, and Basin States. What will be the future of the newer wheat lands is an interesting problem, but one which cannot at present be predicted with any great accuracy, for many of the factors necessary for such a prophecy are unknown. Nevertheless, it is very probable that important wheat extensions will be seen.

California in 1868 raised $21,000,000$ bushels, and had an acreage of 1,050,000. Till 1897, wheat acreage and production steadily rose. The maximum crop was $45,000,000$ bushels in 1896 . Since 1897 the wheat acreage has dwindled from over $3,000,000$ acres to under $1,000,000$ acres. This is most probably due to horticulture, and the progress of irrigation making it more profitable to raise other crops than wheat. Washington and Oregon show on the whole a steady increase in wheat production and acreage in recent years. The crop of Washington in 1910 was $25 \cdot 6$ million bushels, and that of Oregon 16.4 . The greatest 1,000-acre yield of wheat ever reported is ascribed to Eastern Washington in 1881, with 51,000 bushels.

Outside the Pacific Coast States there is no very large wheat-producing state in the Cordilleran region. Idaho, Colorado, Utah, and Montana each raise several million bushels per annum, but their chief interest lies in their future development by "dry farming" and irrigation methods. The Cordilleran total for 1906 was 94,111,584 bushels-a total greater than that of the Atlantic Coast States; but it is to be noted that the western area is much greater than the eastern.

The wheat crop of the United States for 1910 com- 
prised 464,044,000 bushels of Winter wheat, and $231,399,000$ bushels of Spring wheat. Spring wheat provides now a large proportion of the total crop. For the last ten years about one-third of the total United States wheat crop has been Spring wheat.

A feature of wheat production in the United States, that is worthy of attention, is the increased production of Durum or Macaroni wheats in the arid and semi-arid regions. A few years ago these wheats were difficult to sell, but they have now gained a strong commercial position. In 1902 , about $2,000,000$ bushels were raised, while, in 1906, the amount had risen to $50,000,000$, about one-fifth of which was exported to Mediterranean ports.

The United States, as a wheat-exporting country, has long been one of the chief. Russia is her great rival, and she has several times exceeded the United States' wheat export. With the further growth of population in the United States, and the further development of her manufacturing and mining industries, the home consumption of wheat will increase, and Argentina and Canada will doubtless in the future surpass the United States in wheat exportation.

Wheat Exports of the United States, 1900-1909 (Flour INCLUDED).

\begin{tabular}{|c|c|c|c|c|c|}
\hline 1900 & $\cdots$ & & & & $\begin{array}{c}\text { Bushels. } \\
182,925,444\end{array}$ \\
\hline 1901 & $\begin{array}{l}\cdots \\
\cdots\end{array}$ & $\ddot{0}$ & $\ddot{0}$ & $\ddot{0}$ & $266,286,903$ \\
\hline 1902 & $\cdots$ & $\cdots$ & $\ldots$ & .. & $211,941,232$ \\
\hline 1903 & .. & .. & $\cdots$ & .. & $161,271,655$ \\
\hline 1904 & $\ldots$ & $\ldots$ & $\ldots$ & $\ldots$ & $64,957,058$ \\
\hline 1905 & $\ldots$ & $\ldots$ & $\ldots$ & .. & $71,788,579$ \\
\hline 1906 & $\ldots$ & $\ldots$ & .. & .. & $127,309,434$ \\
\hline 1907 & .. & .. & .. & .. & $160,127,925$ \\
\hline 1908 & $\ldots$ & $\ldots$ & $\ldots$ & .. & $151,338,121$ \\
\hline 1909 & $\ldots$ & $\ldots$ & $\ldots$ & .. & $92,085,64$ \\
\hline
\end{tabular}


Europe is by far the most important purchaser, and, of all the countries of Western Europe, the United Kingdom is the chief market for American grain. Of Asiatic purchasers, Japan is the chief. She purchased in the year June 30, 1907, to June 30, 1908, 1,835,522 bushels of wheat, and 84,977 bushels of flour. Wheat-flour exports make a high percentage of the wheat exports ; 10,521,161 flour-barrels were exported in 1909 ( 1 barrel of flour= $4 \frac{1}{2}$ bushels of wheat).

\section{Argentina.}

The importance of Argentina, both as regards her past, present, and future, as a wheat-growing country is apt to be underrated. Her strides have, without doubt, been greater than many realize. The tendency is to look upon Argentina as a poorly cultivated land, and to neglect considerations of her vast wheat lands, of the fact that the low standard of living of the majority of the wheat growers allows of greater wheat exportation than where it is of a high standard, and of the possibilities of wheat extensions.

Argentine statistics are not very reliable, but the figures may be taken to show the progress of her wheat industry (see p. 258).

The wheat acreage shows an almost continuous and gradual rise, and during fifteen years has more than trebled itself. Production shows some remarkable fluctuations, but the last ten years exhibit on the whole a steady increase. 
Wheat Adreage and Produdtion of Argentina, 1895-1909.

\begin{tabular}{|c|c|c|c|c|c|}
\hline \multicolumn{4}{|c|}{ Year. } & Acres. & Production in Bushels. \\
\hline 1895 & . & .. & .. & $4,942,000$ & $61,355,800$ \\
\hline 1896 & .. & .. & .. & $5,584,460$ & $46,402,620$ \\
\hline 1897 & .. & .. & .. & $6,177,500$ & $31,596,400$ \\
\hline 1898 & .. & .. & .. & $6,424,600$ & $53,383,220$ \\
\hline 1899 & .. & .. & $\ldots$ & $7,907,200$ & $105,969,854$ \\
\hline 1900 & .. & .. & .. & $8,080,750$ & $101,644,884$ \\
\hline 1901 & .. & .. & .. & $8,351,239$ & $74,743,856$ \\
\hline 1902 & $\ldots$ & .. & .. & $8,077,946$ & $56,373,856$ \\
\hline 1903 & . & . & . & $9,131,086$ & $103,750,086$ \\
\hline 1904 & .. & $\ldots$ & $\ldots$ & $10,674,720$ & $128,659,134$ \\
\hline 1905 & .. & .. & .. & $12,115,560$ & $150,729,524$ \\
\hline 1906 & $\ldots$ & .. & $\ldots$ & $14,023,666$ & $134,916,628$ \\
\hline 1907 & .. & .. & .. & $14,065,673$ & $155,975,996$ \\
\hline 1908 & $\ldots$ & $\ldots$ & $\ldots$ & $14,231,408$ & $192,469,838$ \\
\hline 1909 & .. & .. & .. & $14,969,694$ & $161,672,000$ \\
\hline
\end{tabular}

Some important and interesting features may be gathered from the table, which follows:

Agreage by Provinges and Territories.

\begin{tabular}{|c|c|c|c|c|}
\hline Provinces and Territories. & 1894-95. & 1899-1900. & $1906-07$. & 1903-09. \\
\hline Buenos Aires & 907,959 & $2,046,235$ & $5,782,943$ & $6,186,642$ \\
\hline Santa Fé .. & $2,547,348$ & $3,691,135$ & $3,261,349$ & $3,311,881$ \\
\hline Cordoba .. & 725,732 & $1,381,519$ & $3,539,390$ & $3,713,419$ \\
\hline Entre Rios & 721,798 & 707,467 & 724,611 & 793,932 \\
\hline Pampa Central and & & & & \\
\hline $\begin{array}{l}\text { the remaining pro- } \\
\text { vinces and terri- } \\
\text { tories }\end{array}$ & 39,163 & 254,394 & 757,380 & $1,071,245$ \\
\hline Pampa Central alone & 一 & 一 & 一 & 790,720 \\
\hline
\end{tabular}

Noticeable features in this table are the great extensions of wheat acreage in the provinces of Buenos Aires and Cordoba since 1895, the decrease in wheat acreage in 
Santa Fé since 1900, the almost stationary condition of the wheat area of Entre Rios, and the rise of the territory of Pampa Central as a wheat district within the last few years.

The best wheat lands of Santa Fé and Entre Rios lie in the extreme southern parts. The northerly tracts are more suited to the growth of alfalfa, maize, and other products. The most favourable conditions for successful wheat-growing exist in the province of Buenos Aires, in Southern Cordoba, and in the territory of Pampa; and Argentina will have to rely largely on the wheat area of these parts. Experience, climatic conditions, and experimentation show that the prospects of extending wheat-growing in a southerly direction into Pampa, Rio Negro, and Chubut are far more hopeful than an extension of the wheat acreage in a northerly direction into Northern Santa Fé, Entre Rios, and Santiago del Estero.

The exportation of wheat from Argentina is now a very important factor in the world's wheat markets. As a wheat-exporting country, Argentina now ranks third, and she has prospects of attaining first rank. Of her total production of wheat, it has been calculated that 9 per cent. is used for seed, 21 per cent. for home consumption, and 70 per cent. for exportation in ordinary years, and this may be taken as approximately correct.

In $1908,1,276,656$ barrels of flour were exported. The yearly average for the period 1904-1908 was almost $1,400,000$ barrels.

From 1894 to 1901 the exports of wheat show great fluctuations, but for the period 1902-1908 there is notice- 
able an almost steady rise. Argentina may be relied upon to provide a wheat export of over 100,000,000 bushels per annum under average conditions.

Wheat Exports of Argentina (including Flodr), 1894-1908.

\begin{tabular}{|c|c|c|c|c|}
\hline & & & & \\
\hline 1895 & .. & . & .. & .. $40,119,675$ \\
\hline $1896 \ldots$ & .. & .. & .. & .. $\quad 22,425,471$ \\
\hline $1897 \ldots$ & .. & .. & .. & .. $\quad 6,048,763$ \\
\hline $1898 \ldots$ & .. & .. & .. & .. $25,480,806$ \\
\hline $1899 \ldots$ & .. & .. & .. & $\begin{array}{l}. \quad 66,261,545 \\
\text {. }\end{array}$ \\
\hline 1900 & .. & .. & .. & .. $\quad 73,746,585$ \\
\hline $1901 \ldots$ & .. & .. & .. & . . $37,217,216$ \\
\hline $1902 \ldots$ & .. & .. & .. & .. $\quad 25,867,164$ \\
\hline $1903 \ldots$ & .. & .. & .. & .. $65,778,855$ \\
\hline $304 \ldots$ & .. & . & .. & . $\quad 90,648,492$ \\
\hline $305 \ldots$ & .. & .. & .. & . . 113,283,308 \\
\hline & .. & .. & .. & .. $89,594,752$ \\
\hline $1907 \ldots$ & . & . & . & . . 105,350,627 \\
\hline $1908<>>$ & . & .. & .. & .. 139,708,222 \\
\hline
\end{tabular}

It is impossible to obtain from Argentine statistics the amount of wheat exported to various countries, for about two-thirds of her total wheat export is sent out in tramp ships, which call at certain ports for orders for final shipment. The exporter seeks the best market, and cables the final port after considering market prices, freight rates, and return cargo. Notwithstanding the absence of exact statistics, it may be said with the greatest certainty that Western Europe is her chief market, and Brazil her most important customer in America.

\section{Other Countries of America.}

Chile and Uruguay are the only other countries of America, having a surplus amount of wheat for export. 


\begin{tabular}{|c|c|c|c|c|c|}
\hline & & & Uruguay. & Chile. & Mexico. \\
\hline \multirow{4}{*}{1905} & (Acreage .. & . & 644,400 & $1,534,000$ & - \\
\hline & Production & .. & $7,565,000$ & $12,089,000$ & $9,710,000$ \\
\hline & Export .. & .. & - & 706,932 & - \\
\hline & (Acreage ... & $\ldots$ & 712,800 & - & - \\
\hline \multirow[t]{3}{*}{1906} & Production & $\ldots$ & $4,606,000$ & $12,157,000$ & $8,000,000$ \\
\hline & Export .. & .. & - & 233,101 & - \\
\hline & (Acreage ... & .. & 623,300 & - & - \\
\hline \multirow[t]{3}{*}{1907} & Production & .. & $6,867,000$ & $15,776,000$ & $10,000,000$ \\
\hline & (Export .. & .. & & $1,487,697$ & - \\
\hline & (Acreage .. & .. & 611,800 & $1,937,700$ & 一 \\
\hline \multirow[t]{2}{*}{1908} & Production & .. & $7,430,000$ & $18,915,000$ & $8,000,000$ \\
\hline & (Export .. & 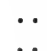 & - & $5,034,831$ & 二 \\
\hline \multirow[t]{2}{*}{1909} & $\left\{\begin{array}{l}\text { Production } \\
\text { Pro }\end{array}\right.$ & $\ddot{0}$ & $8,000,000$ & $20,000,000$ & $8,000,000$ \\
\hline & (Export .. & .. & 一 & - & 一 \\
\hline
\end{tabular}

- Indicates no statistics available.

Mexico imports on an average about 1,000,000 bushels of wheat per annum. No country in South America, with the exception of Argentina, shows signs of any increased importance in wheat acreage or wheat production, and America will for many years, if not for all time, have to depend on the three great countries-the United States, Canada, and Argentina-for her position as a wheat-producing and exporting continent.

The necessary figures for the diagrams have been obtained from official and commercial sources. While the diagrams are, of necessity, only approximately correct, yet some general conclusions may be drawn from them.

The first of the series of diagrams shows the importance of America in the world's wheat production, acreage, and export. America provided on an average 30 per cent. of the world's wheat during the period 1896-1908, and her wheat acreage is about 30 per cent. of the world's wheat 
acreage. As an exporter of wheat, she is the most important wheat-exporting continent. Her lowest wheat export for the period 1896-1908 was nearly 33 per cent. of the world's wheat export, and her greatest over 70 per cent. The second of the series of diagrams shows that the

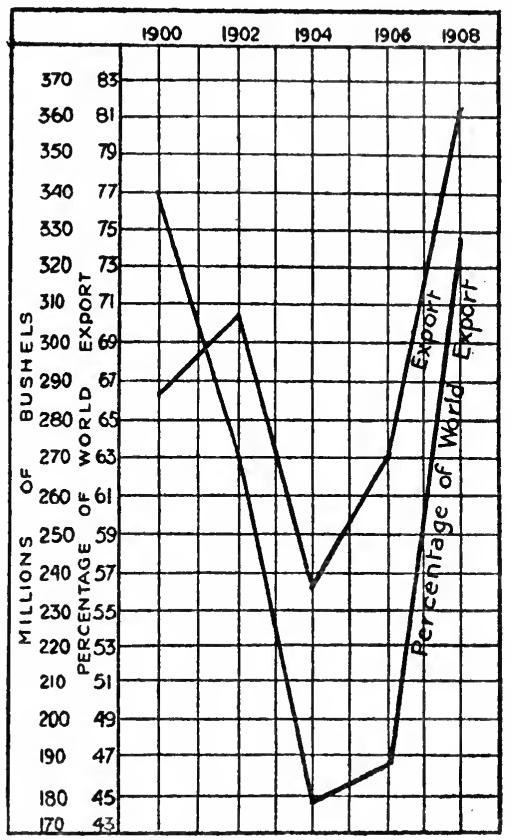

Fig. 24. - Wheat Exports of America and their Relation to THOSE OF THE WORLD.

United States wheat acreage tends to be about 20 per cent. of the world's acreage, while those of Canada and Argentina are increasing, Canada's percentage increasing at a noticeable rate during the last ten years, and that of Argentina at a steady rate. Unless the wheat acreage of the United States increases in future years, her percentage 


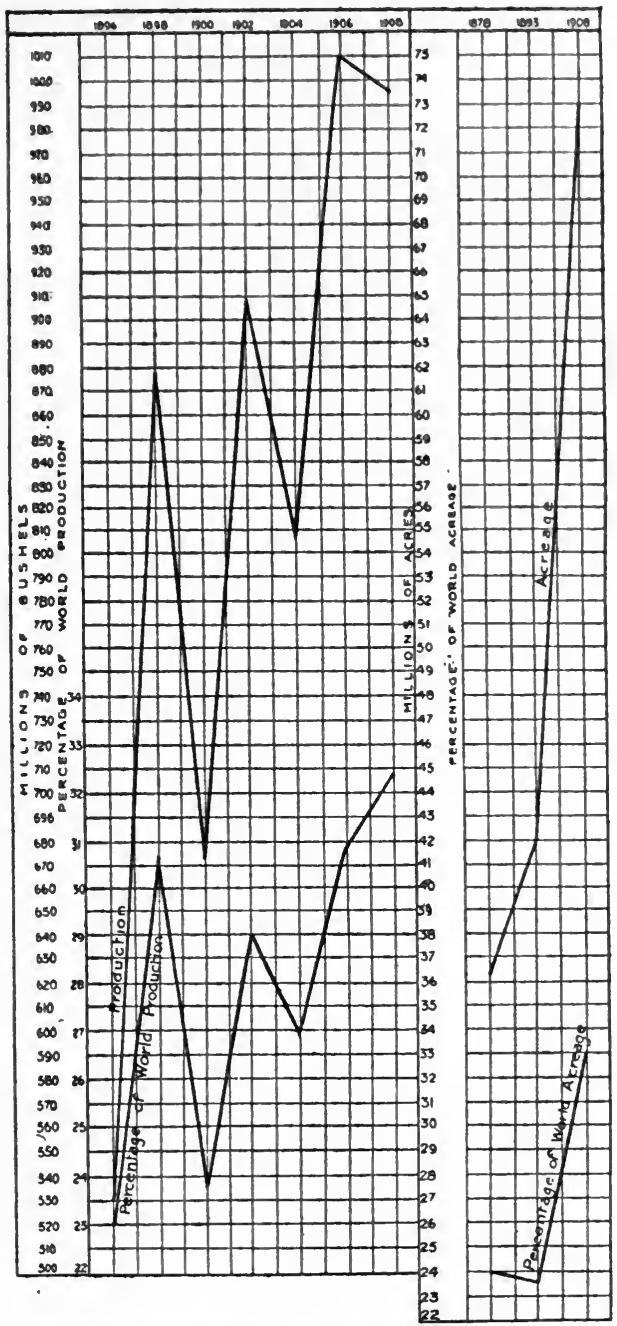

Fig. 25. - Wheat Acreage and Production, of America and their Relation to those of the World. 
of world wheat acreage will decline in view of the increase of wheat acreage in other countries more than balancing the decreased acreage in old developed countries.

The third of the series of diagrams shows the very important position of the United States both in exportation and production. A tendency for her export wheat trade to decline is clearly shown. There is not, however, indicated the probability of the United States becoming, in the near future, an importing wheat country, unless there is a great crop failure. Her percentage of the world production of wheat shows a tendency to decline.

The fourth of the series of diagrams shows that the United States wheat acreage has risen fairly steadily since 1866. Recent years show slight fluctuations, and a tendency to a stationary position is indicated, especially so, if the relation to population is considered.

The fifth of the series of diagrams shows that Canada is becoming of increased importance in both world production and export. Though her position is now but a comparatively lowly one, yet when her vast possible wheat lands and her present great growth of wheat acreage are considered, it may be concluded that her future will be one of great promise. The diagrams for North-West Canada show the great growth of this wheat region during the period 1900 to 1910 .

The sixth and seventh of the series of diagrams show the growth of Argentine wheat acreage, production, and export. Noticeable features are the high percentage of the crop exported, and her increase in the world exportation of wheat. Together with Canada, a decided tendency to increased importance in world production, acreage, and exportation is shown. 


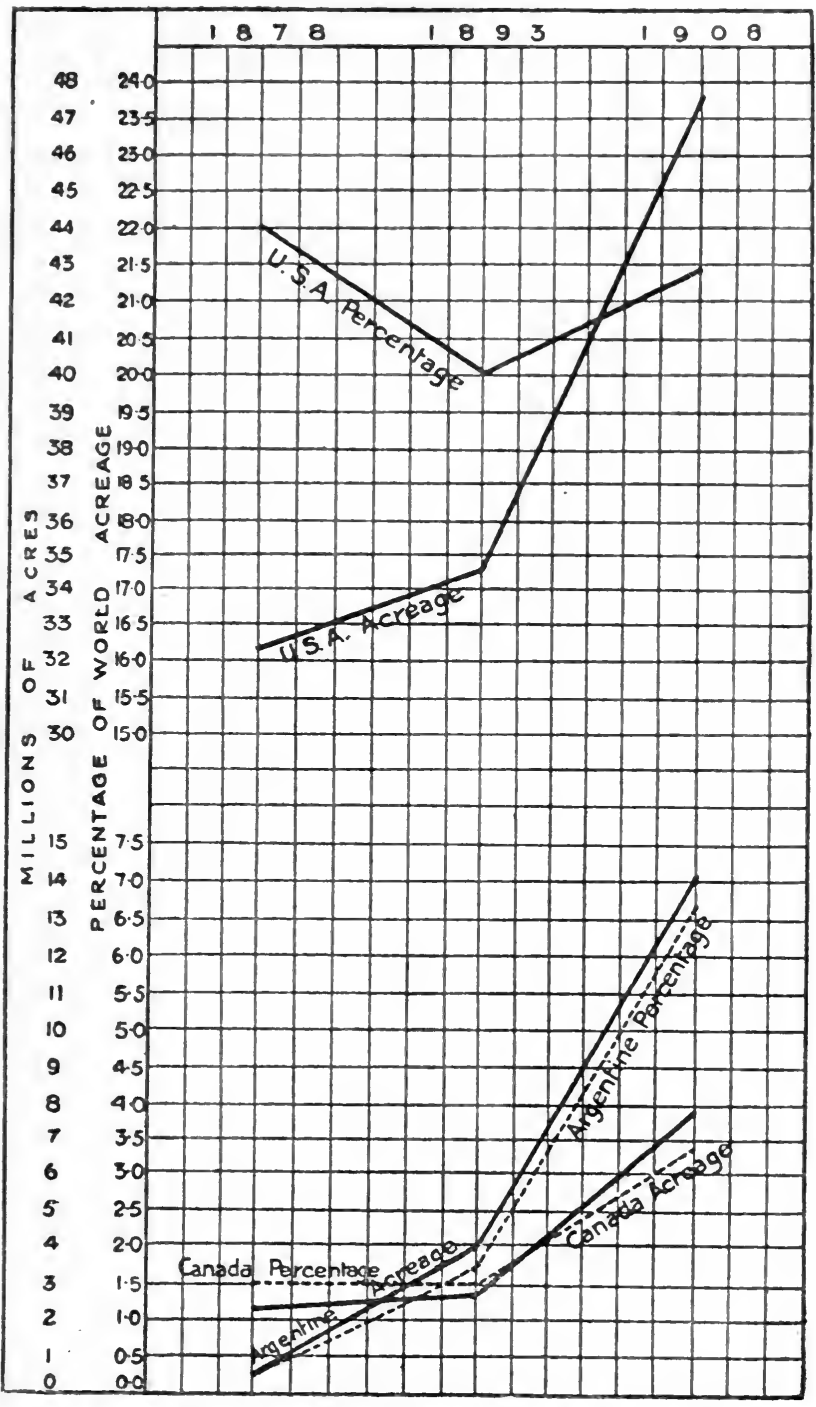

Fig. 26. - Wheat Acreages of Canada, the United States, and Argentina, and their Relation to the World Acreage. 

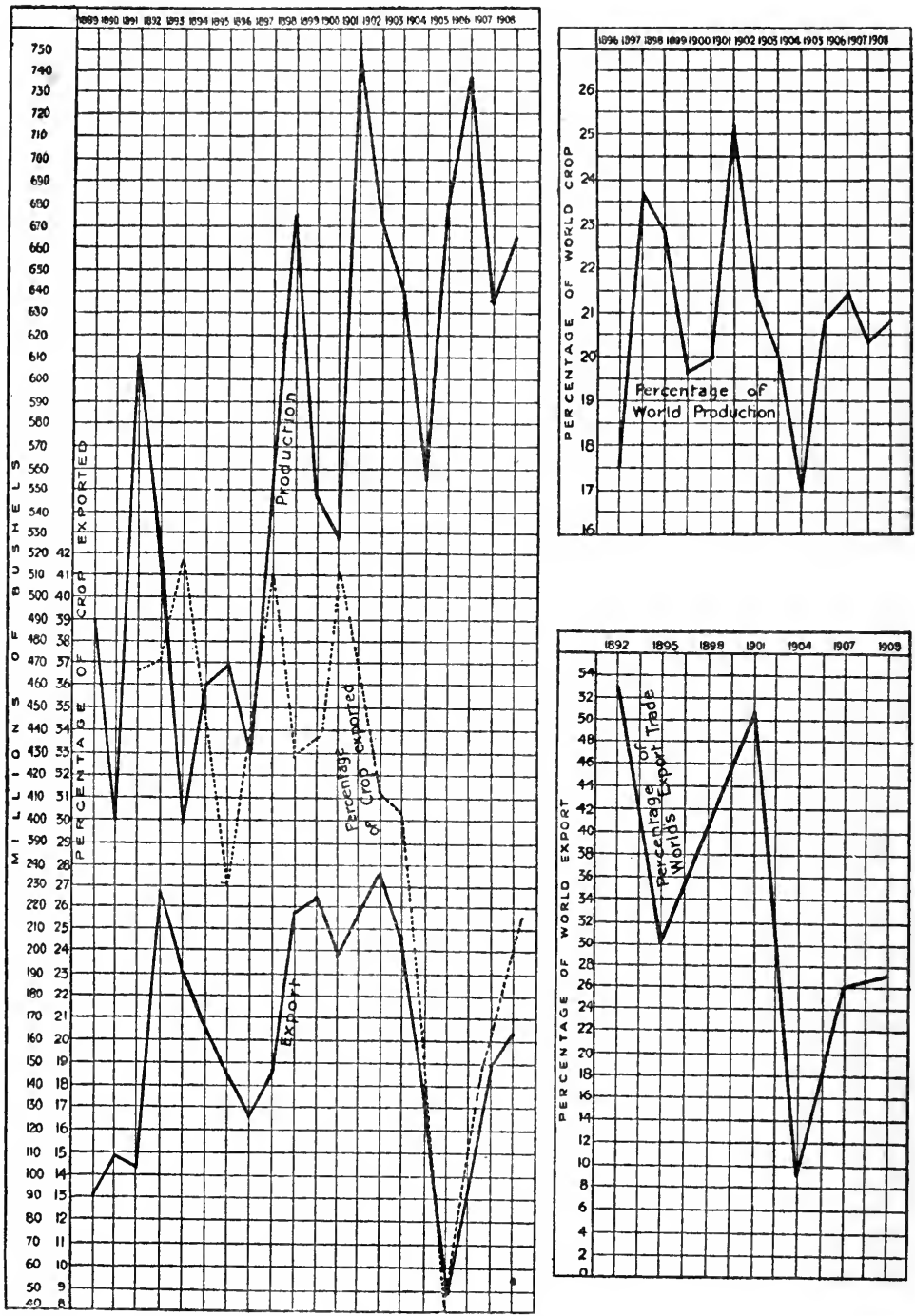

Fig. 27. - Wheat Production and Wheat Exports of the United States, and their Relation to the World Production and EXPORT. 
WHEAT ACREAGE OF UNITED STATES

267

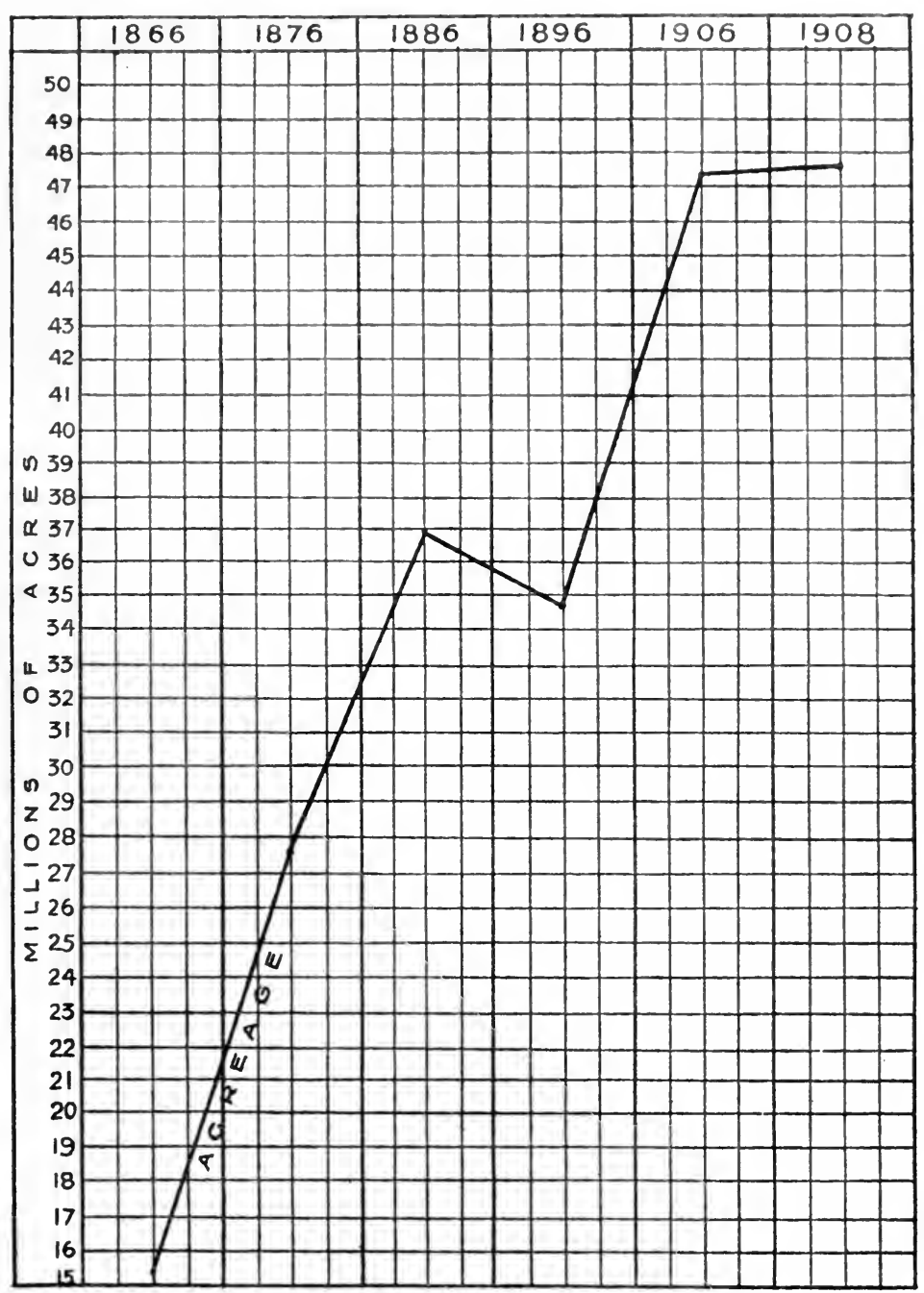

Figr. 28. -Wheat Acreage, United States. 

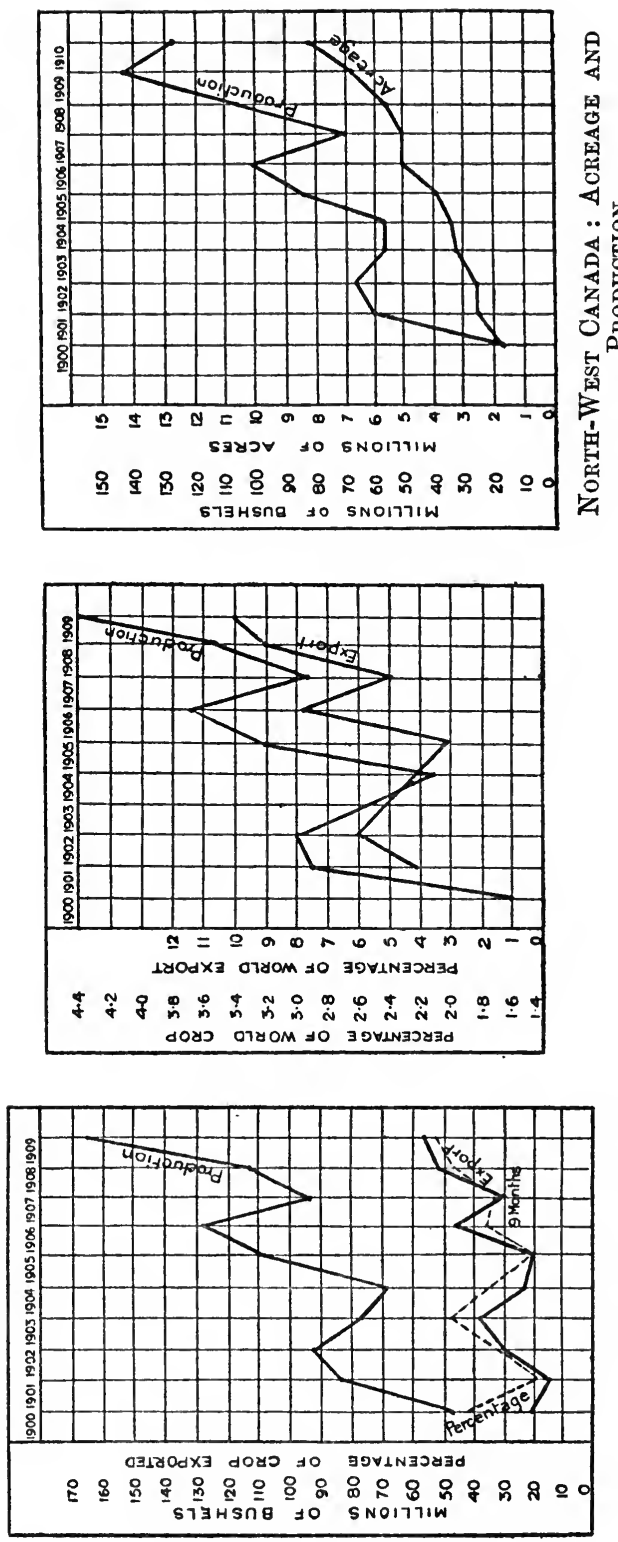

年 


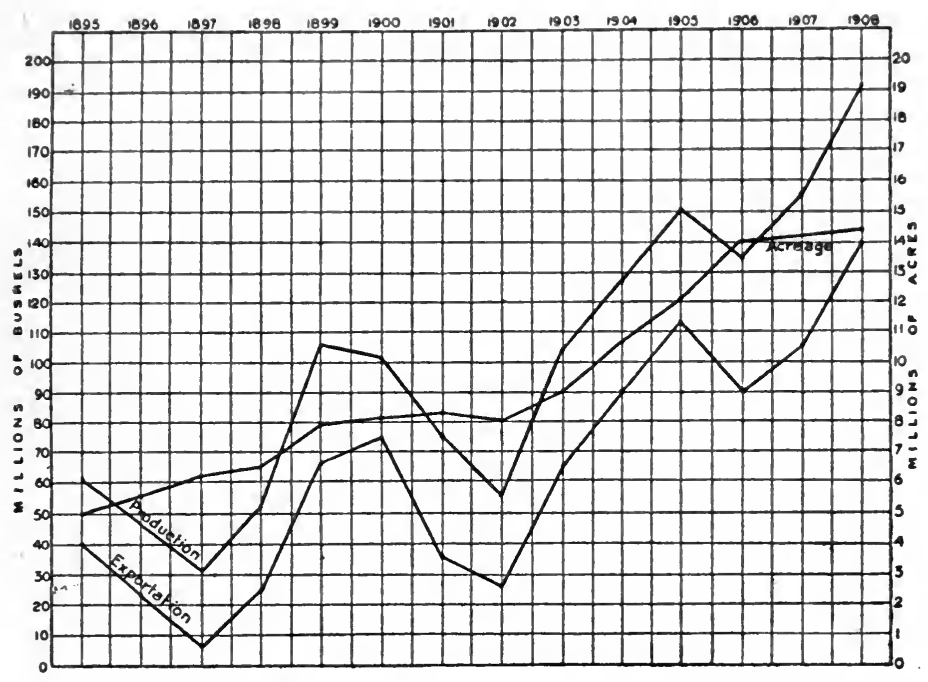

Fig. 30.-Argentina Wheat. 


\section{WHEAT PRODUCTION AND EXPORTS}

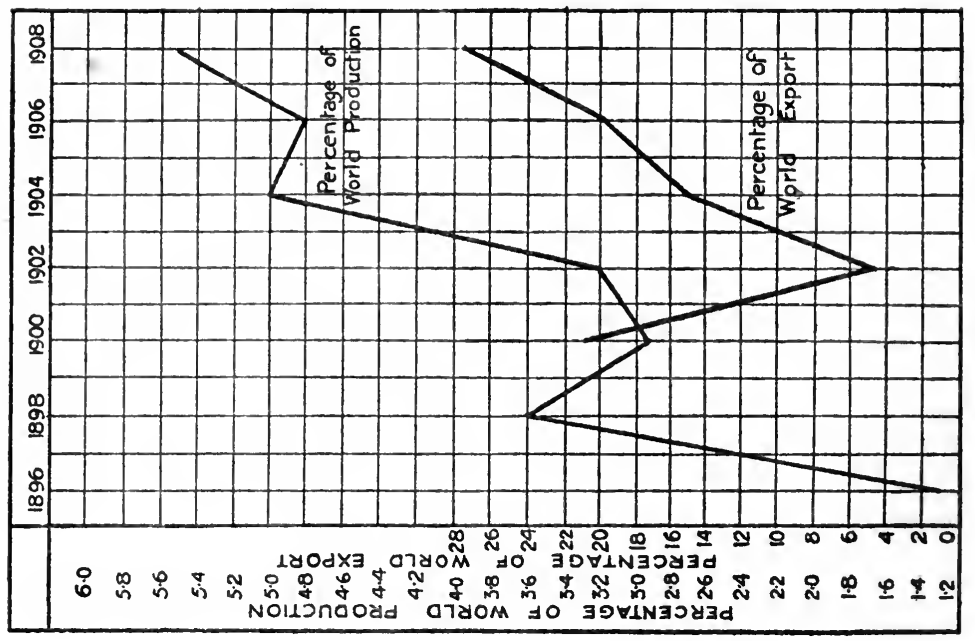

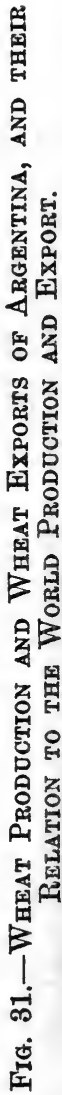

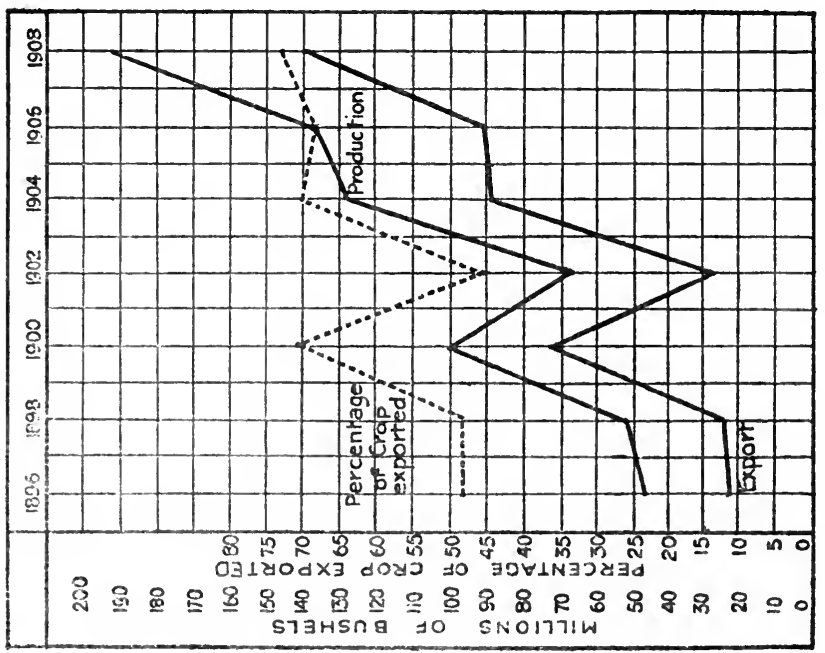




\section{CHAPTER XII}

POSSIBILITIES AND PROBABILITIES OF WHEAT IN AMERICA

THE human mind is incapable of taking into account all the conditions of a problem, whose factors are in the past, present, and future; and this fact must be borne in mind in any considerations of the probabilities and possibilities of wheat in America. Scientists of world-wide renown have given their forecasts of the future of wheat, but factors either known or unknown at the time have been neglected, and the future has proved their prophecies to be wrong. In this chapter an endeavour is made to indicate from some known factors what are the possibilities and probabilities of wheat in America, but the limitations must be recognized.

Agriculture, unlike manufacturing industries, has not advanced with vast leaps during the last hundred years, even in such old, settled, and civilized countries as those of Western Europe, and on the American continent it has not attained the height of that in Europe. Farm work in America was greatly changed by the introduction of improved tools and machinery; nevertheless, agriculture is still the branch of production, which has been affected least by the changes of the last century. The farmer is still bound to the soil, and subject to the weather. Steam-power, which the sanguine thought would work 
vast changes, has not made for itself a very important place in agriculture. The modern transportation system has brought about a revolution in the choice of crops and the means of marketing them, but the methods by which crops are grown have not been vitally affected. If the time should come when the first fertility of new lands shall have been exhausted, and all possible wheat lands shall have been exploited, and population clamours for a cheap food-supply not obtainable by existing farming methods, then a solution must be found to an unsolved problem. Many problems of agriculture have yet to be solved, and among those, which may be called wheat problems, there remain to be investigated the means of increasing the wheat product on the same acreage (though solved in part by seed selection, wheat-breeding, better cultivation, rotation, and fertilization) ; the suitability of wheat for northern latitudes-a problem curiously neglected by Canada of late years ; the problem of wheat in arid lands (solved in part by irrigation, "dry-farming," and the introduction of Durum wheats); and the true relation of climate and soil to wheat-growing, with its many attendant problems.

Science may one day astonish the world by rendering aid in multiplying the yield of wheat, or in enabling food products to be manufactured in the laboratory. If the genius of invention should be able to accomplish the marvellous either by nitrogen obtained from the air, by the distribution of bacteria over the fields, or by bringing in the mystery of electricity, it would go far towards solving the world's bread problem; but, until that day dawns, it must remain an impracticable ideal. 
The problems of wheat in America are many and varied, and each country has its own peculiar problems to face.

\section{The United States.}

It has often of late been asserted that the United States will soon become a wheat-importing country, owing to her increased mining and manufacturing population. Mr. James J. Hill considers that an increased agricultural population is essential, if the home food-supply is to be sufficient for home demands. There is, however, an agricultural population sufficient for present needs, if it were more intelligent. Poor farming is largely at the root of the matter.

It is interesting to compare the total population per year with the wheat product and wheat acreage. It is clear from the diagram on the next page that the wheat product and wheat acreage are not keeping pace with the population. Population has not, however, increased so fast in the later decades as in the earlier, as the following table shows :

Decade before 1860 increase $35 \cdot 7$ per cent.

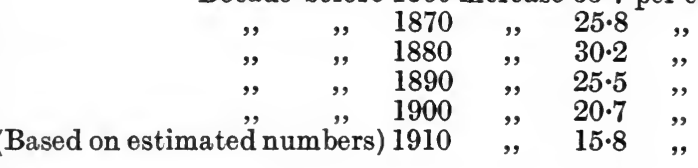

As nations advance to a higher stage of civilization, the tendency is for the normal increase of population to be checked. Motives of economy and of opportunity for self and offspring press strongly on mankind as standards rise, and the rate of increase of population declines. It would seem that the higher the type the fewer the 


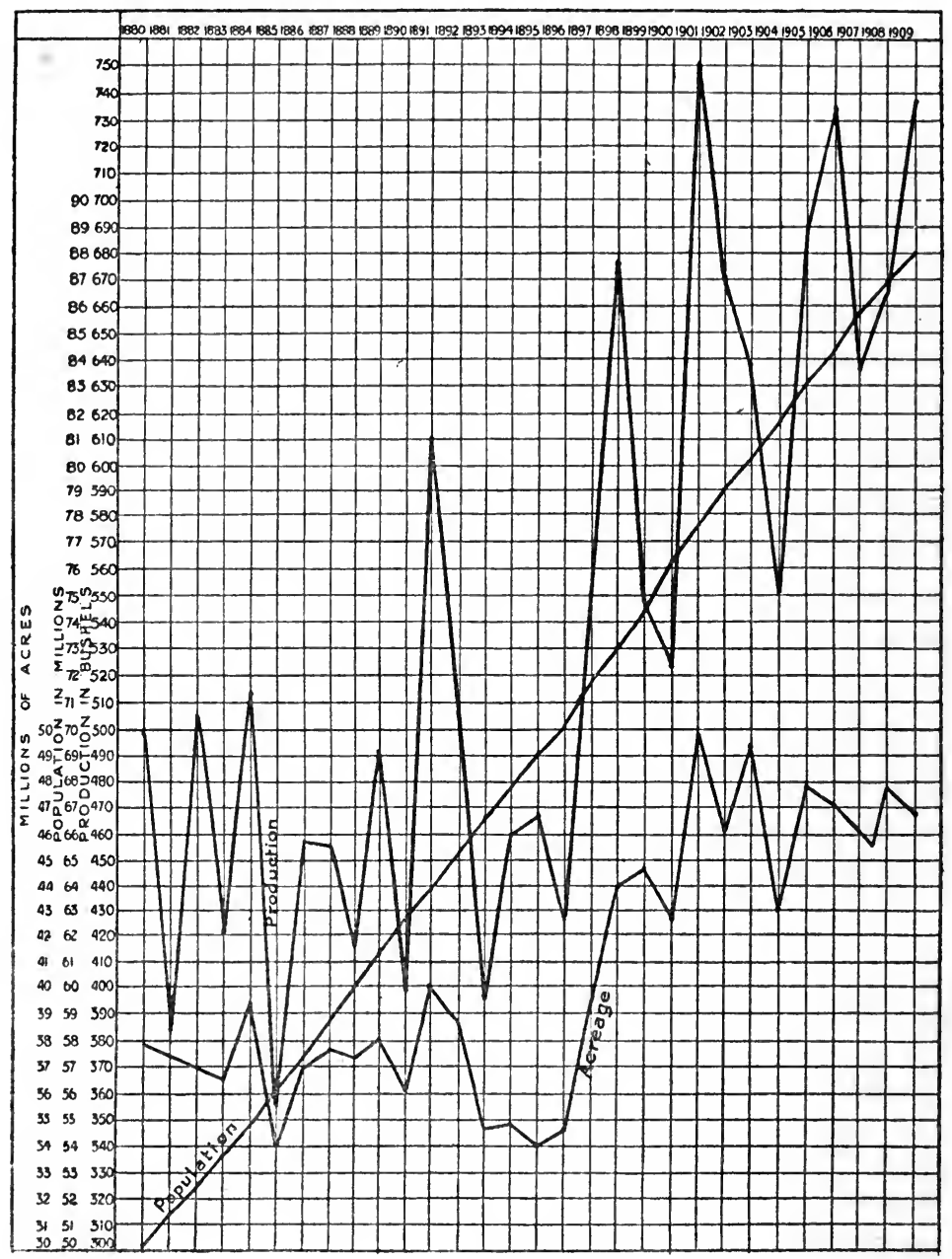

Fig. 32.-Relation of Population in the United States to Wheat Production and Acreage. 
progeny. Again, approaching scarcity of food-supply accompanied by higher prices would tend to still further restriction.

Up to the present time immigration has been one of the chief sources of the United States population. A check to the inflowing current is clearly evident now, and this may become permanent in future years, especially in view of the restrictive measures of the Government. Other factors tending to decrease immigration are the lesser opportunities of acquiring free land, and the triumphs of democracy leading to improved conditions of life in European countries, which have supplied a large part of this immigration.

Though it would seem that various writers have exaggerated the effects of the failure of wheat production to keep strides with the growing population, the United States must pay attention to the securing of an increase in her wheat output. She has excellent opportunities for doing this. On her present exploited lands she could, by intensive cultivation, greatly increase her supply. Intensive farming, in some respects, has commenced. Mr. M. A. Carleton, Cerealist of the United States Agricultural Department, says: "We can hardly consider that intensive cultivation of wheat has begun in the United States, although we are probably very near that stage. Already there are better yields per acre, but this may be largely due to the use of improved varieties rather than to cultivation. The area devoted to wheat on any one farm is becoming smaller, and, of course, that will give a chance for better cultivation than heretofore." E. L. Bogart says: "The future growth of cereal pro- 
duction will depend more upon improved methods of agriculture than upon the addition of new lands."

When a settler first attempts the cultivation of new land, labour in comparison with land is the more important element. Within general limits, it is less a question what can be obtained from an acre, than what can be obtained from the labour of a man or of a team. New land requires comparatively little cultivation. The native plants perish under the new conditions produced by the plough, and the weeds of older communitiesplants that have become adapted to the conditions in cultivation-do not at once trouble the farmer. For a time, close cultivation does not bring a reward in increased results. The man with two horses can produce a greater quantity of grain, but it may be at a low rate per acre. In the progress of settlement, the product per acre grows in importance as land is relatively less available. Hitherto, the border of the dense population in the United States has been busy with extensive farming, but the wellwatered rich lands are so fully occupied that intensive farming of some degree becomes yearly more prominent. With the further growth of the country, the United States will become more and more dependent for food-products for domestic use and for export upon systems of cultivation that tend to develop the greatest capabilities of the acre as compared with the pioneer plan of getting the most possible for the labour of the man and of the beast, with minor regard to unit of land.

There are signs that the United States farmer is becoming more intelligent in his methods. $\mathrm{He}$ is learning to adapt his crop to his soil, and to his market. Adaptation 
of wheat to conditions of soil and climate, and the more intelligent and energetic use of fertilizers are certain to increase the wheat product. California is said to have used six times as much artificial fertilizers in 1900 as in 1890 , and in the Red River Valley the yield of wheat has, in some cases, been increased from 15 to 20 bushels per acre by fertilizing. Much might be done by utilizing the available farmyard manure, which is, in many cases, wasted now. Travellers over the Eastern States assert that there are many poor and hungry farms, where the manure-heaps often lie leaching for two consecutive years. Resources are wasted, too, by the methods of sewage disposal. Highly concentrated nitrogenous products, which have with much toil been wrung from a depleting soil, are allowed to flow to the sea.

Crop rotation is rarely practised to any great extent in a new country, for capital and human labour are then comparatively scarce and dear; but, as population increases, and lands become exhausted, and cheap or free land is not to be obtained, rotation of crops becomes necessary. The restoring of old wheat lands and the retention of the average yield have been done by crop rotation. A report of the Industrial Commission of the United States asserts that, so far as is known, the soil will produce 12 or 13 bushels to the acre annually for many years. America has, however, to face the problem of increasing her wheat yield, and rotation of crops offers a part solution.

Pioneer farmers at first plough what they can, and after the decay of the soil they plant or sow all available land, and then harvest by wholesale methods. Wheat is 
a convenient pioneer crop, and particularly Spring wheat. It can be rapidly put into all ground that is ready, and the farmer trusts to his opportunities in a later month to harvest. Increasingly as the years go on, he needs part of his ploughed land for other food crops. Some neighbours occupy the adjacent wild lands, which at first supplied the principal food for his cattle. Part of the cultivation must now be to produce food for the animals. The introduction of diversified crops tends to decrease the pioneer wheat area. This is well shown in the decrease of wheat acreage in parts of Iowa, Michigan, and California. Large farms tend to break up into smaller ones as land becomes more valuable, and hence must yield a greater return, and the United States has now, perhaps, reached the stage when this tendency is setting in strongly.

More labour and better directed labour is required in an intensive system of farming than in an extensive, and this as regards intensive wheat farming depends primarily on the price of wheat. In the regions of sufficient rainfall for crop-growing in ordinary seasons in the United States, comprising roughly the eastern half, there were in 1900 only seven tillers of the soil to each 91.4 acres. Even if generous allowance is made for ground not in tillage, the amount of labour is far too inadequate to bring the maximum product from the soil.

The problem of arid lands has only been partially solved by "dry-farming" and irrigation, and since lands of an arid or semi-arid type embrace about two-fifths of the area of the United States, every effort should be made by her to obtain a solution of this interesting, but difficult problem. Some wheat experts are of opinion that a 
rather important increase in wheat acreage will come through "dry-farming" over the extensive arid western areas of the United States. This will, however, depend in part on improvements in transportation in these regions, the settlement of a mining population to provide a market, and the price of wheat. Irrigation will aid in adding new lands to wheat. In the census year 1899, 99 per cent. of Arizona wheat was irrigated, 84 per cent. of that of Colorado, and 57.4 per cent. of that of Utah. These facts show that the yield can be enlarged where wheat is already grown by "dry-farming " methods, as well as by bringing new lands under the ditch. The cost of irrigation works, however, may make extensive wheat-growing impracticable, because other crops permit more intensive farming, and offer larger returns. Mr. Samuel Fortier, Chief of the Irrigation Investigations in the United States, says: "Irrigation will probably not extend the wheat area to any great amount. Wheat takes considerable water, and at a time when water is very scarce. The yields of wheat are not sufficient to make the value of the product equal to that of other crops, that can be grown in the same climate with less water. The chief use of wheat in irrigation sections will be in the rotation of crops." Irrigation is valuable to the small farmer and fruit-grower, and will probably give but a small new acreage to wheat, and that but slowly. All the projects of irrigation approved, in construction, or investigated and found feasible will only add a little over 5,000,000 acres to existing cultivated land, and only a small percentage of these acres will probably be cultivated with wheat. Judging from present factors, then, the arid West will not 
see a very great extension of wheat acreage. Probably, it may largely provide bread for the Cordilleran dwellers.

A gain of wheat territory may come from the drainage of marsh lands, both of the marine and fresh-water type. Swamps have been converted into fertile tracts in Europe, and similar work can be done in America. Professor Shaler esimates that 100,000 square miles of swamplands in the United States could be reclaimed, and that their production would equal that of Ohio, Indiana, and Illinois. Many of these lands are near to the great eastern markets, and are well adapted to intensive wheat culture. Forest lands may also be cleared for needful and effective tillage, and their place counterbalanced by the foresting of areas unfit for the plough.

Lands, now lying comparatively idle in the east and south, though formerly wheat-growing areas, will probably to some extent balance the future decrease of western acreage caused by diversified farming. The increase of wheat acreage and production in various Eastern States of late years is worthy of notice. Lands, which passed out of wheat cultivation in the east and south owing to the action of the Law of Decreasing Returns, may again come under the plough, when the returns from them equal the returns from the new lands, and this may result not only from the yield equalling or more than equalling that of the margin land in the young wheat districts, but also from the nearness to markets, transportation facilities, and the conversion of wheat lands in the newer tracts to diversified farming areas. The growth of population, and the further development of mining and other non-agricultural industries will result in a greatly increased home 
consumption in the west, and the tendency will then be to diminish wheat exports from the Western States, and may result in the sending of some surplus wheat from the Central States to the west, instead of exporting to foreign countries.

Wheat-breeding may result in increasing sensibly the output of wheat, and this it may do in two ways : First, it may increase the wheat acreage ; and, second, it may increase production on the same area. The second method is probably the more important. Dr. T. L. Lyon says : As population increases, the demand for land for other crops increases proportionally, and as long as the wheat-fields of Canada continue to be productive, there will be a tendency for the wheat acreage of the United States to gradually decrease, provided a prohibitive tariff is not built up I believe that the advantage in wheat production will be with Western Canada, as compared with the United States, and that improved methods, of production will be adopted there, as readily as in this country. In view of the rapid development of wheat-growing in that region, and of the uncertainty of tariff protection in this country, it seems to me impossible to make any predictions as to what effect improved methods of wheat production may have on the amount of wheat produced in this country." Though it is impossible to predict the improvements that wheat-breeding might effect for various economic causes, yet it provides at least a solution for increasing the output. Luther Burbank stated that if a new wheat were bred, that would yield only one grain more to each head, Nature would produce annually, without effort or cost to man, 15,000,000 
extra bushels of wheat in the United States alone. None of the so-called good wheats of America, according to various wheat experts, are good croppers, even under intensive cultivation. Better-yielding wheats will doubtless be bred. The experiments being carried on at the present time are good omens for the future.

Some important wheat lands may come from the tracts along the 240,000 miles of railway. This, however, is a remote contingency. Transportation may play a part in increasing the wheat acreage. Mr. F. R. Rutter, of the United States Department of Agriculture, says: "There are far larger wheat tracts not yet opened to the great markets, owing to lack of railways, than is generally realized, particularly in the south-west."

Previous chapters have shown that the United States has the progressive appliances, the skilled energy of production, the highly developed facilities for transportation, storage, and marketing, and the climatic and soil conditions for almost every variety of wheat; that the cost of production is low in many parts ; that wheat prices are much more uniform than in the past; and that, though her farming is extensive, the beginnings of an intensive system are evident. Such factors as these suggest that, though there is a tendency for the wheat export to decline, yet the time when the United States will cease exporting wheat is somewhat remote. That a time will come when the United States will become a permanent wheat importer seems certain, if considerations are given to her development since 1860, and the teaching of history as shown in our own and other countries of Western Europe. Should the present duty on wheat of twenty-five cents 
per bushel be taken off, as now (1911) seems probable, the United States will certainly reach the permanent wheat-importing stage much earlier. The advantage in production will lead to Canadian wheat finding a good market in the United States.

The conclusions to which we must come are that the United States has great possibilities for wheat production, but to what extent they will be further developed or diminished cannot be predicted with any certainty, for the effect of economic factors, past, present, and future, cannot be fully estimated; and that the probabilities are that she will follow the example of the United Kingdom, and rely upon other newer countries or older countries with economic advantages in wheat production for part of her wheat supply. A fact that is clearly brought out by present conditions is that the farming of the future must ultimately be one of more careful tillage, of more scientific rotation, and of considerations for the changes in the grouping of population, and on the world-wide conditions of man and his varying wants.

\section{Canada.}

Canada, as a wheat-growing country, offers a striking contrast to the United States. She has but comparatively recently come to the fore in the exportation of wheat, and she does not, and perhaps never will, feel the pressure of population on her wheat supply. The population of Canada has always increased slowly. In 1801 her population was about 240,000 ; in $1901,5,371,315$; and at the present time it is about 7,000,000.

It will be impossible for some years to come to gain 
even an approximate idea of the possibilities of Canada as a wheat producer. Various estimates have been made of the possible wheat lands of Western Canada, but the geographical and economic factors governing the problem are so many, so complex, and impossible to wholly gauge, that such estimates can never give anything but an inadequate idea of future growth of wheat territory. Among the geographical factors to be taken into account are the nature of the soil and the climate, including the numerous minor factors, such as moisture in the soil, chemical constituents of the soil, winds, temperature, rainfall, humidity, and sunshine; and among the economic factors, perhaps more difficult to estimate, are the transportation facilities, marketing, and storage of wheat, growth of population, the cost of production, and the price of wheat. Dr. William Saunders has not, however, withdrawn his reasonable prophecy of 1904-that wheat, grown on one-quarter of the $171,000,000$ acres of land in North-West Canada said to be capable of cultivation, would, with the yield of Manitoba for the previous decade, give a crop of more than $800,000,000$ bushels, which (estimating $7 \frac{3}{4}$ bushels per capita) would feed about $30,000,000$ people in Canada, and allow nearly $600,000,000$ bushels for exportation. If there is a surplus of threequarters of $171,000,000$ acres of good soil, there will be ample room for diversified crops, and for such rotations and fallowing as might be needful in future years to meet the declining production of depleted prairie soils.

Canada is destined for many years to come to rely on her agricultural products ; her manufacturing and mining industries are of minor importance. For development of 
her vast wheat lands she needs a far greater population, especially in Western Canada, and for the growth of her population she must depend mainly on immigration. In contrast with Argentina, her immigrants are intelligent, and have usually had experience of the kind of farming necessary. There are great inducements to settlement in Canada. Free lands are obtainable, transportation facilities are being rapidly developed, the farmer feels secure and free under an enlightened Government, marketing and storage facilities are well advanced, the land is fertile, and the climate favourable. The growth of population in the Canadian North-West during the last ten years has been remarkable. In 1900-01, 17,987 Americans crossed the border into Canada; in 1908-09 the figures rose to 59,832 . In the twelve months ending March 31, 1910, they rose to 103,798 . In the ten years, March 31, 1900, to March 31, 1910, the total immigration from the United States into Canada has been 497,248, while that from the British Isles has been 562,054. The total immigration into Canada for the period June 30, 1900 , to March 31, 1909, was 1,244,597, and of this number 973,077 settled in the prairie provinces.

The following table gives the population of North-West Canada in 1901 and 1906 (later figures are not available, but the great growth of population through immigration may be gauged from the figures already given) :

\begin{tabular}{|c|c|c|c|c|}
\hline Year. & Manitoba. & Saskatchewan. & Alberta. & Total. \\
\hline 1901 & $\begin{array}{c}255,211 \\
365,688\end{array}$ & $\begin{array}{c}186,159(\mathrm{~N} . \mathrm{W} . \text { Provinces) } \\
257,763\end{array}$ & $\begin{array}{c}441,370 \\
185,412\end{array}$ & 808,863 \\
\hline
\end{tabular}


There is every probability that the American invasion will continuc. It is to be noted that this invasion is of capital as well as people. The almost certain abrogation of the duty on Canadian wheat into the United States will lead to greater wheat acreage. Granting that the population of the North-West is sure to increase, Canada will be able to give herself to a greater agricultural specialism. Unlike the United States, she must confine herself to the products of temperate climes, and her greatest reliance for exchange in the future, as in the past, must, it would seem, be upon the products of extractive industries, and among these the raising of food-products must occupy a high place.

Considering the vast area of North-West Canadamore than four and three-quarter times the area of the United Kingdom-and making allowance for the area under water, it is evident that there is a vast amount of land that could be put under wheat. Much of this area is as yet virtually unexplored, and the potentialities of that which has been explored can only be approximately estimated. Nevertheless, the statement may safely be made that the possibilities are great. Climate and soil are known to be favourable in many parts, transportation and storage facilities are being rapidly developed, and, if the necessary population were there, factors indicate the prosperity of the region.

The extension of the Canadian wheat lands in a northerly direction has engaged the attention of the Dominion authorities for some years past, but the work has never been of a very scientific character. Probably, when the wheat lands to the south have been taken up, 
stricter investigation into the possibilities of the more northerly tracts for wheat-growing will be conducted. Experiments in the Peace River district at Fort Vermilion in 1908 and 1909 indicate that, when pressure comes on the older wheat lands, reliance may be put on the Peace River Valley district. The following are details of fire samples of wheat sent from Fort Vermilion to Dr. William Saunders in 1908 :

\begin{tabular}{|l|c|c|c|c|}
\hline $\begin{array}{c}\text { Name of } \\
\text { Variety. }\end{array}$ & Date of Sowing. & $\begin{array}{c}\text { Date of } \\
\text { Harresting. }\end{array}$ & $\begin{array}{c}\text { Weight per } \\
\text { Bushel in } \\
\text { Pounds. }\end{array}$ & $\begin{array}{c}\text { Percentage of } \\
\text { Germination. }\end{array}$ \\
\cline { 1 - 3 } Preston .. & May 6 & August 22 & $64 \frac{1}{2}$ & 100 \\
Ladoga.. & April 31 & September 5 & 64 & 92 \\
Ladoga .. & May 4 & August 24 & 64 & 99 \\
Early Riga & April 21 & August 21 & 63 & 96 \\
Riga .. & May 9 & August 29 & $64 \frac{1}{2}$ & 100 \\
\hline
\end{tabular}

The table given below of meteorological observations taken at Fort Vermilion from July 1, 1908, to March 31, 1909, shows that climatic conditions are not unfavourable to hardy and quickly maturing wheats :

\begin{tabular}{|c|c|c|c|c|c|c|}
\hline \multicolumn{3}{|l|}{ Month. } & $\begin{array}{l}\text { Mean Tempera- } \\
\text { ture in Degrees } \\
\text { Fahrenheit. }\end{array}$ & Rainfall. & Snowfall. & $\begin{array}{l}\text { Total } \\
\text { Precipitation } \\
\text { in Inches. }\end{array}$ \\
\hline July & $\ldots$ & & $60 \cdot 68$ & $2 \cdot 30$ & - & $2 \cdot 30$ \\
\hline August .. & .. & .. & $57 \cdot 26$ & $2 \cdot 05$ & 一 & $2 \cdot 05$ \\
\hline September & .. & .. & $45 \cdot 32$ & $0 \cdot 69$ & - & 0.69 \\
\hline October.. & $\ldots$ & $\ldots$ & $31 \cdot 25$ & $0 \cdot 33$ & $2 \cdot 00$ & $0 \cdot 53$ \\
\hline November & .. & .. & $8 \cdot 45$ & 一 & $8 \cdot 50$ & 0.85 \\
\hline December & .. & . & $-7 \cdot 90$ & - & $2 \cdot 50$ & 0.25 \\
\hline January & .. & .. & $-25 \cdot 08$ & - & $5 \cdot 75$ & 0.58 \\
\hline February & .. & . & $-15 \cdot 32$ & 一 & 1.50 & $0 \cdot 15$ \\
\hline March .. & .. & . & $14 \cdot 47$ & - & $4 \cdot 25$ & 0.43 \\
\hline
\end{tabular}


From Fort Simpson, 818 miles north of Winnipeg by latitude, Ladoga wheat has been obtained which weighed $62 \frac{1}{2}$ pounds per bushel. A small percentage of the grain was, however, injured by frost. The wheat was sown on June 7, and harvested September 22, giving a growing period of 107 days. This is the farthest point north from

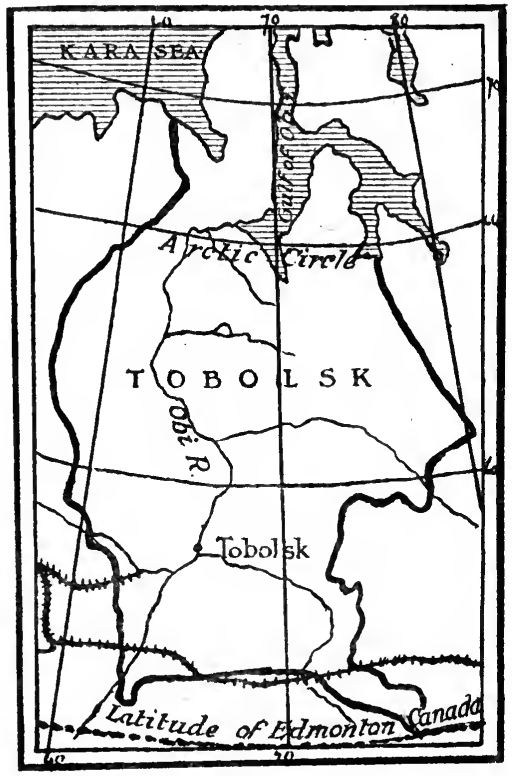

Fig. 33.-Province of Tobolsk.

Wheat, $1900: 6,480,000$ bushels.

which samples of wheat have been received at Ottawa. Wheat ranges in Eurasia to $63 \frac{1}{2}$ degrees north latitude. The accompanying map shows the Siberian province of Tobolsk, which in 1900 yielded $6,480,000$ bushels of wheat. There is thus evidence that there are possibilities of the extension of wheat acreage in Canada's northern latitudes. 
The breeding of new wheats is one of the methods by which it is hoped to make wheat encroach on the northerly tracts, and among the varieties already bred, Preston, Stanley, and Marquis are the most promising, ripening earlier than Red Fife, and having high gluten contents. Kowalewski, the Russian investigator, believes that the short seasons of quick growth in the North gradually bring about in hardy wheats an early ripening habit ; and Dr. W. Saunders is of opinion that with early ripening cereals this habit is a permanent characteristic, which they continue to manifest when grown in localities where the summer season is longer.

Transportation will certainly play a large part in the increasing of the wheat acreage in Canada. We may see in the future some of the land to be traversed by the Grand Trunk Pacific Railway in Western Canada become a vast wheat tract, and possibly a part of the land to be traversed by the Hudson Bay Railway; then there are also possible vast wheat tracts in British Columbia. The late Dr. Dawson and Professor Macoun credit the capabilities of that portion of the Peace River Valley lying within British Columbia with 10,000,000 acres of wheatland. The factors for success in these regions would seem to be economic-the opening of a commerce with the Far East, and a mining population to develop the mineral fields of the North-West and those of British Columbia. The Panama Canal may also prove a factor in providing a new route to Europe for wheat, which will probably be conveyed in part by tramp ships coming from the East in ballast. Alberta suffers now from high freight rates. Some of the finest grain in the world is grown in Alberta, 
the bulk of which is raised between Edmonton and Cardston, north and south, and for a distance of about 100 miles east and west-an area, which is gradually increasing. The nearest Lake port is Fort William, which is 1,400 miles on an average from the wheat district of the province, while the wheat fields of Manitoba and Saskatchewan are located something like 800 miles nearer to that port. From the districts of Manitoba and Saskatchewan the freight rates are eight or nine cents per bushel, while those from Alberta are fourteen or fifteen cents per bushel. It is clear, therefore, that wheat raised in Alberta and going to Liverpool via the Lakes and Montreal is handicapped against that going from Saskatchewan and Manitoba by the same route. The freight rates, however, from points in Alberta to Liverpool via Vancouver are just the same as via Fort William, but there is this advantage-that the former port is open to navigation all the year round; and when the Panama Canal is open to traffic the distance to Europe will be cut in half, and the freight rates will be greatly reduced. Again, when elevator facilities are provided on the Pacific Coast, it will be possible to ship grain to Europe all the year round. The recent increase of wheat exports from Vancouver is noteworthy. In $1907,31,245$ bushels of wheat were exported; in 1909, 196,983 bushels; and in 1910, 554,237 bushels.

The extensions of wheat lands by irrigation and "dryfarming" in Southern Alberta, Southern Saskatchewan, and parts of British Columbia will probably be small "Dry-farming " experiments are now being conducted at the Dominion Experimental Farm at Lethbridge, Southern 
Alberta, and at the Kamloops Farm, British Columbia. Probably "dry-farming " and irrigation methods will be combined on the farms, and, as in the United States, diversification of crops may result. Whether irrigation can be applied economically to wheat-raising depends largely on the cost of water, and the returns from the sale of the wheat. In some parts of Alberta, notably in the irrigated lands of the Canadian Pacific Railway Company in the Bow River Valley, it is said to pay well. As a general rule, however, in Canada irrigated land is devoted largely to the growing of alfalfa, which is a crop that returns more money than wheat.

There are lands lying idle in the Eastern Provinces more vast than is generally recognized that may become future wheat lands, and possibly lands now under other crops may be seeded to wheat. This may come to pass when the economic advantages of eastern lands for wheatgrowing equal those of the west. Factors bringing about this equality may be the depletion of prairie soils, and comparative nearness to markets. Eastern Canada has been forced to engage in mixed farming by economic and climatic conditions, and so her wheat output has declined; but, given the necessary favourable economic conditions, the chances are that her wheat production will materially increase.

Canada has, like the United States, the transportation, marketing, storage, and financial facilities necessary for the development of wheat production. She has also intelligent farmers, and the soil and climate suitable for many varieties of wheat. She possesses an advantage over the United States in her greater yield per acre of 
wheat, which is assigned by some to better farming, and by others to climatic and soil factors. Doubtless, each plays its part. As in the United States, little intensive farming has been carried on, but the commencement is evidenced in smaller holdings, rotation of crops, and summer fallowing, and Canada shows signs of using all the aids to agriculture that science can give, or may be able to give.

It is not unwise to predict that future wheat exporting on a large scale from America will be with Canada rather than with the United States or even Argentina. No other conclusions are possible than that Canada has greater possibilities of an immediate and rapid increase in wheat production than any other country in America, and that, though it is not possible to gauge all her potentialities as a wheat producer, yet her possible future wheat lands would seem to be greater than those of the United States or Argentina. The probabilities are that North-West Canada will be settled like the North Central States of the United States, and while diversified farming will be carried on, it will not be practised to any great extent in the wheat area for some years to come. Intensive farming will be practised on a large scale in the older districts first, and as the population increases, this system will become common. British Columbia's wheat-fields may increase to an appreciable extent, but industries such as fruit-growing, lumbering, and mining will engage many of the population. The Eastern Provinces, by adopting an intensive system of farming, may increase their wheat output, but it will be long before the need for this, or the advantage in it will arise. 


\section{Argentina.}

The possibilities and probabilities of Argentina as a wheat producer have not received much serious attention from wheat experts. She is usually looked upon as an undeveloped country, and one far from her markets. Whilst these statements are undoubtedly true, there are yet many indications of a bright future for Argentine wheat. Conditions are changing for the better. Elevators are being built at the ports; the milling industry is becoming better organized; the Department of Agriculture, established about ten years ago, is doing excellent work; transportation facilities are being improved; the marketing system is slowly developing into a more perfect form; the right localities for raising wheat are being more certainly determined; and improved methods of farming are being slowly adopted. With his great natural advantages of climate and short haul to the seaboard, the Argentine wheat-producer, making the best use of his opportunities, must be a strong competitor in the world's wheat markets.

The population of Argentina increases slowly, and with such slow growth it will be many years before the wheat tracts are fully developed. The following figures show the growth of population :

$$
\begin{array}{lllllll}
1869 & . & . . & . . & . . & . & 1,830,214 \\
1872 & . & . & . . & . . & . & 2,231,049 \\
1888 & . & . & . . & . . & . & 3,158,434 \\
1895 & . & . & . . & . . & . & 3,954,911 \\
1909 & . . & . . & . . & . . & . . & 6,805,684
\end{array}
$$

Immigration mainly supplies the labour on the wheatfields, and the immigrants are largely Italians and 
Spaniards. During the period 1857 to $1908,2,594,666$ Italians and Spaniards emigrated to Argentina. The total immigration was $3,178,456$.

Farming methods in Italy and Spain are poor, and, though there are signs of improvement now, the immigrants farm by the old methods in Argentina. What Argentina needs is capable agriculturists with some capital. The Argentine Government offers no incentive to poor immigrants from the best-developed countries in Europe-Great Britain, Germany, and France-but is content to attract immigrants from Mediterranean lands, who, though better adapted to the conditions of climate and labour, will only develop the country very slowly. Only a small portion of the settled area is, as yet, producing even half the yield of wheat of which it is capable. If Argentina can increase the number of the right type of "colonist" - the one who buys his land on a permanent colony-her prosperity will be more assured. The temporary "colonist," who breaks the soil of new land, and then moves to a new district at the end of his term, tends to make conditions worse for wheat production. This latter "colonist" owes his origin largely to the growing of alfalfa, a clove-like plant, which requires little rain, but thrives on the surface-water, which is abundant on Argentina's flat, low-lying plains. Alfalfa will not grow on hard unbroken ground, and where the land is such, cereal cultivation is necessary for at least three years to reduce it to a fit condition. A contract is made by the cattle-kings with Piedmontese or Basque peasants to break the soil, and grow cereals for three or five years, either for a fixed rent or for a percentage of the crop, the 
stipulation being that with the last year's soed alfalfa shall be sown as well. It is said that as alfalfa is more cultivated the stock-bearing capacities of Argentina will easily be trebled. The growth of alfalfa may affect the wheat acreage to a considerable extent in some parts; whether it will check the continued increase of wheat acreage will depend largely on the returns from wheat and stock-raising respectively.

Drawbacks to wheat production are the difficulties of the labour problem, the lack of storage facilities, the poor marketing system, the lack of financial aid to the wheatgrowers, the vast size of the farms, the lack of rotation in many parts, the need of more transportation facilities, the climatic disadvantages, and the scourge of locusts. Another drawback is that the Government is not too stable. Statesmanlike qualities are sometimes absent in the rulers, and public morality is but now finding a place. The wheat-grower cannot, therefore, feel that sense of security that is possible in Canada and the United States.

Various estimates have been made of possible wheat lands in Argentina. Señor Tidblom, an authority on Argentine agriculture, says: "It is absolutely impossible to predict the growth of wheat territory, but there are more than $80,000,000$ acres in the Republic that could immediately be devoted to successful wheat-farming, if we had the farmers to do it." Mr. William Goodwin. F.R.G.S., wrote in 1895 : "If one-half of the supposed suitable land were to produce a crop of 10 bushels of wheat per acre, the result would be $1,237,815,000$ bushels." Possibly, wheat could be grown in all regions of Argentina, with the exception of those south of 48 degrees south 
latitude, the stony ridges in Chubut territory, the mountainous ground north or south, the whole country north of 30 degrees south latitude, and the western plateaux of San Luis and Mendoza. Some idea of the possible extent of wheat territory can be formed, but all that can be safely said now is that the wheat acreage in Argentina is yearly increasing, and getting into a region of very great extent, and of an adaptability superior to that of the region in which it was started, and that development will depend largely on population, and the extension of railways and river navigation. If suitable settlers go to Argentina in large numbers and stay there, then it is possible for a tremendous production of wheat. Railway service will doubtless be provided as fast as there is a demand for it, but there does not seem to be much prospect that the roads will be materially improved for some time to come.

Argentina could increase her wheat production by the introduction of "drought-resisting" wheats in the semiarid parts, by irrigation, and by "dry-farming," but the need for these has not yet arisen. Intensive farming will doubtless be long before it is adopted universally. A factor, indicating that diversified and intensive farming will be adopted in the future in the wheat tracts, is that land is steadily rising in price. Small holdings are slowly increasing in Argentina, but it will probably be many years before the large farms generally decrease in size.

Considerations of soil and climate lead to the conclusion that Argentina can never hope to rival Canada and the United States in the production of "strong" wheats, but the breeding of new wheats may improve the 
quality and increase the production. It is specially noteworthy that the Argentine soils, though classed as fertile, suffer in comparison with the soils of Canada. Russia, on her "black lands," has the advantage in production over Argentina, if careless and ignorant methods of agriculture shall continue to prevail in Argentina. The present methods of farming can only be successfully followed upon virgin soils, and Argentina needs to consider the future, when all the new lands shall have been scratched over. The Argentine Department of Agriculture is aware of the ignorance of the majority of the wheat growers, and has recommended them to plough more deeply, to select the best seed, and to rotate crops. Better farming must come, if the country is to compete strongly in the world's wheat markets, and this Argentina can only secure by giving examples to her ignorant wheat farmers, for they are too illiterate to be reached through printed matter.

Argentina must for many years rely upon the production of raw materials. Stock-raising and cereal production must, from the conditions of soil and climate, and the quality of the labour, be the main industries. The condition of agriculture in Argentina is partly due to the fact that stock-raising cast it into such a deep shadow, that it could not thrive. The tilling of the soil has been rather looked down upon by the cattlekings, who owned (and still largely own) the greater part of the good land in the country, and did not want it broken up. They would neither sell nor rent the land till recently for cereal-growing. "Estancieros" (stockraisers) are doing their part now in the development of agriculture. They are finding it very profitable to have 
their natural grass-land broken up by renters, who pay a good rental for wheat land, and leave it covered with alfalfa at the end of their period. While this has increased the wheat territory for a time, yet in some parts, where the conditions are permanently favourable for alfalfa, wheat acreage tends to decrease. Alfalfa requires more water than wheat, and in the provinces of Cordoba and Santa Fé, where nearly half the annual rainfall occurs during the summer, the wheat-grower has many anxieties, which are only blessings to the alfalfa farmer. In 1895, the acreage under alfalfa was about 1,750,000, and in 1909 it was over $11,000,000$. Attention must be paid also to the growth of maize, and the conditions favouring its production on the Lower Parana and its tributaries. Its production has increased over 140 per cent. since 1895. Should the United States cease to export maize, it is quite possible that some parts of the wheat tracts may be given over to maize.

Cattle and sheep rearing have so far been found to be more profitable than wheat-growing in Southern Argentina, but it is possible that the future may see much land under wheat in Rio Negro and Chubut. The Welsh Colony in Chubut made a gallant attempt, but circumstances were against them at the time. No one can aver that grain cannot be raised in a latitude of 42 to 48 degrees near the level of the sea, and the fall of irregular and insufficient rainfall is not necessarily a bar to cropraising. Given a very active demand for Plate wheat, it is quite possible that at some not very far-distant date there will be a grain export trade from the ports south of Bahia Blanca. 
Possibly, the greatest drawback to the further development of the wheat lands in Argentina is the scarcity of labour, which, by existing conditions, must depend on immigration. Land, climate, and railroads are available potentials of Argentina, but labour is not yet assured. However extensive and productive the wheat-lands may be, and however ready railroad capital may be to push into new wheat regions, there can be no increase in production on a large scale without an adequate supply of suitable labour. This subject has received much attention in Argentina, and many causes are assigned. The principal reasons given are the bad administration of justice, and the imposition of oppressive taxes in some of the provinces. Incentives should be offered to foreigners to stay in the country. Many of them do not become citizens, and there is much emigration back to Europe. In some years the total has reached 60,000 . Necessary reforms are slowly but surely coming, and doubtless better conditions will largely solve the labour problem.

Notwithstanding the disadvantages, it is reasonable to say that Argentina, with her vast lands, comparatively mild climate, and her signs of awakening to the needs of better conditions in agriculture, has vast possibilities for wheat production.

The probabilities are that her future will be a bright one, but development will come slowly. Probably, she will be passed in the exportation of wheat in the near future by Canada, but she is likely to keep her position as the third wheat-exporting country. 


\section{Other Countries of America.}

The remaining wheat countries of America show few signs of even minor growth of wheat production. Uruguay seems to have reached a stationary position. Stockraising seems to be more profitable than wheat-growing in many parts. In Chile, there are large extensions of land not cultivated, and it is assumed that Chile could easily produce $70,000,000$ bushels of wheat on 7,500,000 acres. Before, however, Chile can greatly increase her wheat output, she must overcome most, if not all, of the following disadvantages: The scarcity of transportation facilities on account of insufficient railroads from east to west to connect the interior with good shipping ports ; the need of more steamship lines for the exportation of the produce ; the high freight rates; the lack of sufficient labour, as in Argentina ; the primitive farming methods ; and, finally, the scarcity of capital, which tends to create high rates of interest on money invested in farming. Mexican agriculture has progressed much in recent years, but is, nevertheless, practically in its infancy, and the soil is cultivated to only a limited extent. Better organization of land and labour, together with improved methods of farming, are essential to increased wheat production in Mexico.

It is safe to conclude that Uruguay, Chile, and Mexico will be very slow in further developing their wheat lands, and that it is improbable that the other republics will ever become even of minor importance as wheat-growing countries.

In conclusion, it is perhaps fitting to indicate what 
may be the future of America with regard to the problem of the world's wheat supply. It has been indicated that the United States wheat export will still further decline, but this may be more than counterbalanced by the increased exportation of Canada and Argentina. Even though the world's wheat demand will yearly increase as population increases, and nations with a low standard of living adopt wheat as their chief bread product, yet America, it would seem, will still keep her place as a wheat exporter. There is probably more chance of new wheat lands being developed in America than in Manchuria, arid and semi-arid Australia, India, and the other possible wheat lands in Africa and Asia. 



\section{BIBLIOGRAPHY}

Аввот, H. L. : Problems of the Panama Canal. New York, 1905.

Annual Reports of -

The British Association. London, 1909 and 1910.

The Chicago Board of Trade. 1907-1911.

The Home-Grown Wheat Committee. London, 1906-1911.

The Minneapolis Exchange. 1907-1911.

The most important American Railway Companies. 1907-1911.

The Now York Produce Exchange. 1907-1911.

Anuario del Servicio Meteorolójico. Valparaiso, 1906-1910.

Bartholomew, J. G., Herbertson, A. J., and Buchan, A. : Atlas of Meteorology. Edinburgh.

Brffen, R. H.: "Strength" in Wheat. Journal of Agricultural Science, vol. ii., part 1. London.

Bureau of American Republics, Washington-

Handbooks of the American Republics.

Monthly Bulletins.

Canadian Department of Agriculture, Ottawa-

Agriculture in British Columbia. 1908.

Agricultural Statistics. 1900-1911.

Annual Reports of the Experimental Farms. 1900-1911.

Atlas of Canada (J. White).

Canada Year-Book. 1905-1910.

Canada's Fertile North Lands. 1907.

Census and Statistics, Monthly.

Census of Canada. 1901.

Census of Manitoba, Saskatchewan, and Alberta. 1906.

Clover as a Fertilizer (Dr. W. Saunders and F. T. Shutt). 1902.

Geological Surveys. Summary Reports. 
Canadian Department of Agriculture, Ottawa-

Grain Statistics. 1907-1911.

Immigrants of the Agricultural Class in the North-West. 1909.

Immigration Reports. 1907-1911.

Monthly Weather Review.

New British Columbia. 1908.

Progress of Agriculture in Canada. 1907.

Quality in Wheat (Dr. C. E. Saunders and F. T. Shutt). 1907.

The Canadian Climate (R. F. Stupart).

The Climate of Manitoba and the North-West Provinces (R. F. Stupart).

The Cruise of the Neptune (A. P. Low). 1906.

Western Prairie Soils: Their Nature and Composition (F. T. Shutt). 1910.

Wheat-growing in Canada (Dr. W. Saunders). 1904.

Candolle, Alphonse DE: Origin of Cultivated Plants. New York, 1885.

Chapman, Professor S. J.: The Lancashire Cotton Industry. Manchester, 1903.

Chisholm, C. G. : Handbook of Commercial Geography. London, 1909.

Conlon, T. : The St. Lawrence Route : Its Past and Future. Thorold (Canada), 1909.

Crawford, A. F. : An Inquiry into Wheat Prices and Wheat-Supply. Journal of the Royal Statistical Society. London, March, 1895. Crookes, Sir William : The Wheat Problem. London, 1900.

Davis, C. Wood : Dealings in Options. New York, 1891.

Davis, W. G. : Climate of the Argentine Republic. Vol. iii. of the Agricultural and Pastoral Census. Buenos Aires, 1909.

DAY, CuIve : A History of Commerce. London, 1907.

Dewey, T. H. : Futures, Options, and Short Sales. New York, 1905.

Dondlinger, Dr. P. T. : The Book of Wheat. New York, 1908.

Emery, Professor H. C. : Futures of the Grain Market. Economic Journal, 1899.

, , Speculation on the Stock and Produce Exchanges of the United States. Columbia University, 1896.

Estadística Agrícola. Buenos Aires and Santiago, 1905-1910. 
GILBert, J. H. : Remarques sur la Relation qui existe entre les Sommes de Température et la Production agricole. Paris, 1893.

Hall, A. D. : The Soil. London, 1908.

The Quality of English Wheat. Journal of the Farmers' Club. London, June, 1904.

Hann, Juluus : Handbuch der Klimatologie, vols. ii. and iii. Stuttgart, 1897.

HUвBACK, J. H. : Argentina. Liverpool, 1908.

Hunt, Professor F. T. : Cereals in America. New York, 1904.

Isthmian Canal Commission, Washington. Manual of Information on the Panama Canal.

KILLICK, S. H. M. : Manual of Argentine Railways. London, 1910.

La日itTe, E. : Agricultural Investigations. Buenos Aires, 1908.

LAwes, J. B., and Gilbert, J. H. : On some Points in the Composition of Wheat Grain. London, 1857. Our Climate and our Wheat Crops. London, 1880.

Lyon, Dr. T. L. : Examining and Grading Grain. New York, 1907. LYoN, Dr. T. L., and Fippin, F. O.: The Soil. London, 1910.

Magazines and Periodicals-

Argentine Year-Book. London.

British Board of Agriculture Journal.

Century Magazine, May, 1903. The Chicago Board of Trade (W. Payne).

Corn Trade News. Liverpool. (G. J. S. Broomhall.)

Corn Trade Year-Book. Liverpool. (G. J. S. Broomhall.)

Cosmopolitan, November, 1898. Wheat and its Distribution (J. Leiter).

Milling (Weekly Corn Trade Journal). Liverpool. (G. J. S. Broomhall.)

North Western Miller. Chicago.

Popular Science Monthly, July, 1908. The Mississippi River

Problem (Dr. W. S. Towar).

Railroad Age Gazette. New York.

Statesman's Year-Book. London. 
Magazines and Periodicals-

Symon's Meteorological Magazine. London, August, 1905 (article by R. H. Curtis).

The American Elevator and Grain Trade.

Marshall, Professor A.: Principles of Economics. London, 1891.

MAvor, Professor J. : Report to the Board of Trade on the North-

West of Canada, with special reference to Wheat Production for

Export. London, 1905.

Merz, Alfred : Beiträge zur Klimatologie und Hydrographie Mittelamerikas. ILeipzig, 1901.

National Railway Publication Co., New York. Official Railway Guide.

Oppel, A. : Natur und Arbeit. Leipzig, Bibliographisches Institut.

Reports of the British Board of Trade on Options and Futures. Parliamentary Sessional Papers, 1903 and 1907.

Schimper, A. F. W. : Plant Geography. Oxford Press.

Shaw, Dr. W. N. : An Apparent Periodicity in the Yield of Wheat for

Eastern England. 1885-1905. Proceedings of the Royal Society. London, 1906.

Shindler, Dr. : Der Weizen in seinem Beziehungen zum Klima und das Gesetz der Korrelation. Berlin, 1893.

Sievers, W.: Süd- und Mittel-Amerika. Leipzig. Bibliographisches Institut.

Smith, Roluiv E. : Wheat Fields and Markets of the Worid. St. Louis, 1908.

Supan, A. : Grundzüge der Physischen Erdkunde. Leipzig. Veit. Stanford's Compendium of Geography: North, South, and Central America. London.

State of Minnesota : General Information concerning State Inspection, Weighing, and Handling of Grain. 1899.

United States Department of Agriculture, Washington-

AвbE, Cleveland : Relations between Climates and Crops. 1906. Agricultural Statistics. 1900-1911.

Andrews, Frank : Cost of Hauling Crops from Farms to Shipping Points. 1907. 
United States Department of Agriculture, Washington-

ANDREWs, FrANK: Crop Export Movement and Port Facilities on the Atlantic and Gulf Coasts. 1905.

, , Freight Rates and Market Values. 1906.

, , Grain Movement in the Great Lakes Region. 1910.

" , Ocean Freight Rates and the Conditions affecting them. 1901.

Bicknell, F. W. : Wheat Production and Farm Life in Argentina. 1904.

Blodgetr, J. H. : Relation of Population and Food Products in the United States. 1901.

Buckivgrux, E. : Studies in the Movement of Soil Moisture. 1907. Carlerton, M. A. : Macaroni Wheats. 1904.

" , Successful Wheat-growing in Semi-arid Districts. 1900.

The Basis for the Improvement of American Wheats. 1900.

Emmer. 1900.

Chilсотт, E. C. : "Dry-land Farming" in the Great Plains Area. 1908.

Clark, C. C. : Wheat Crops of the United States, 1866-1906. 1908. Commercial America. 1900-1911.

Crop Reporter.

FAIlYER, G. H. : The Management of Soils to conserve Moisture. 1906.

GARDNER, F. D. : Fertility of Soils as affected by Manures. 1908. Hartley, C. P. : Harvesting and Storing Corn. 1907.

HAYs, W. M. : Plant Breeding. 1901.

HeNry, A. J. : Climatology of the United States. 1906.

Hrul, G. G. : Marketing Farm Produce. 1905.

Holmes, E. S.: Wheat-Growing and General Agricultural Conditions in the Pacific Coast Region of the United States. 1901. Immigration Reports.

Irrigation Reports.

KING, F. H. : Investigations in Soil Management. 1903.

Lyos, Dr. T. L. : Improving the Quality of Wheat. 1905.

MEAD, ELwOOD : The Relation of Irrigation to "Dry-Farming." 1905.

Monthly Weather Review. 
United States Department of Agriculture, Washington-

Rubinow, Dr. I. M.: Russia's Wheat and Wheat Flour in European Markets. 1908.

Russia's Wheat Surplus. 1906.

Scofield, C. S. : "Dry Farming" in the Great Basin. 1907.

, , , The Commercial Grading of Corn. 1903.

," , The Description of Wheat Varieties. 1903.

Soil Surveys and Soil Survey Book.

Stockman, W. B.: Periodic Variation of Rainfall in the Arid Regions. 1905.

Temperature and Relative Humidity Data. 1905.

Tenth, Eleventh, and Twelfth Census Reports.

WARD, E. G. : Methods and Routes for Exporting Farm Products. 1904.

Whitney, Milton, and Cameron, F. K. : The Chemistry of the Soil as related to Crop Production. 1903.

Year-Books (Agriculture). 1900-1911.

Zinthe, C. J. : Corn-Harvesting Machinery. 1907.

Voss, E. L. : Niederschlagsverhältnisse von Südamerika. Gotha, 1907.

VRIEs, Hugo DE : Plant Breeding. Chicago, 1907.

Watson, N. L. : The Argentine as a Market. Manchester, 1908.

Woods, A. F.: Inoculation of Soil with Nitrogen-Fixing Bacteria. 1905.

The Present Status of the Nitrogen Problem. 1906. 


\section{N D E X}

A

Aereage-

America, 261, 262

Argentina, 257.259, 262, 264, 265, 269

Canada, 241-244, 262, 264, 265, 268

Chile, 261

Mexico, 261

United States, 248-256, 262, 264, 265,267

Uruguay, 261

Advantages, 47, 48, 85, 106, 135 , $150,282,291,292,299$

Aid of science, 272,292

Alfalfa, 294, 295, 298

Alkali soils, 24

"Almacenero," 192-193

Altitudinal range, 5-6

Amount of seed, 113-114

Appalachian Mountains, 60-61

Argentine seasons, 89

Arid regions, 9, 11, 31, 60, 63, 74$78,278-280$

“Arrendatarios," 105

Arrival of cargoes, 187.188

"Arroyos," 86

Atchison system (railway), 154

\section{B}

Bacteria, 10, 14, 36, 37

Baltimore and Ohio Railway, 154

Barletta, 91, 92, 94

"Bear" speculation, 213

Binders, 117

Black soils, $7,10,14,43,44,51$

Blue stem wheat, 68,77

Boards of Trade, 210
“Bonanza" farmers, 115, 128, 172 farming, 115 farms, 107,115

Box cars, 134, 170

Broad-casting, 113

Brokers, 215

Buenos Aires and Rosario Railway, 164

Buffalo, 182

"Bull" speculation, 213

C

"Calls," 213-214

Canadian Northern Railway, 138

Canadian Pacific Railway, 48, 135 . 137

Canadian ports, 145

Capillary water, 8, 9, 10

Cash sales, 219

Cecil series of soils, 66

Central America, 83.85, 300-301

Central Argentine Railway, 164

Centre of production, $3,4,5$

Certificates of weight, 198

Champlain Canal, 162

Chicago market, 220-222

Chile, $97.102,172,260-261,300$

Chinook winds, 46

Classes of ocean vessels, 187

Classification of American wheats, 40.42

Clays, $8 \cdot 10$

Clearing houses, 218-219

Climate-

Argentina, 88-90

British Columbia, 50-51

Central America, 83.85

Chile, 99-101 
Climate (continued)-

Eastern Canada, 52-53

Mexico, 83-84

North-West Canada, 44-50

United States, 61-64

Uruguay, 96

Climatic conditions-

Durum wheat, 17, 24

Spring wheat, 14-16, 24

Winter wheat, 16-17, 24

Clover, 35-36

Club wheats, 41, 81, 82

Clyde series of soils, 65,66

Colonies, 105, 294, 295

Combined harvester, 117

Combined harvester and thresher, 118-119

Commercial grades, 199-202

Commercial wheat regions, 5

Common bread wheats, 40

Competition of steamers and sailing ships, 188

Conditions of wheat-growing, 1-2

Conservation of moisture, 8, 31-32

Continental climate, 21

Continuous market, 212

Contract grades, 200-201, 222-227

Contract-making, 216

Controlling factors of yield, 7-40, 103-129

Cost of production-

Argentina, 128, 129, 130

Canada, 129

United States, 128

Crop rotation, 37-38, 277

Cultivation of wheat, 111-115

\section{D}

Day degrees, 18-20

Decrease of population, 273-274

Decrease of wheat acreage, 245-255

Delivery by transferable order, 216217

Delivery, time of, 214-215

Demand, 208, 228, 229, 230

Deposits, 214

Development of marketing, 191, 193, 209-210

Direct settlement, 217

Disadvantages, 88, 89, 133, 169, $193,205,299$

Distance and value, 161-162
Distance to local markets, 136, 170

Distribution-

Altitudinal, 5-6

Latitudinal, 4-5

Longitudinal, 3

Diversified farming, 121, 278

Division of the wheat-fields, 42-103

Dockage, 195

"Dominant" characteristic, 26, 27

Drilling, 113

Drills, 113

" Drought-resisting " wheat, 17, 42

" Dry-farming" -

Argentina, 296

British Columbia, 51

Canada, 48, 49, 50, 51, 290, 291

Conditions and effects, 31-34

United States, 76-78, 279

Duluth market, 224-225

Durum or macaroni wheat, 17, 24, $33,41,72,73,74,77,91,256$

E

Early ploughing, 38

Early ripening wheats, 25, 41

Early sowing, 17

Eastern movement of wheat, 3

Economic controls, 2

Effects of-

Concentrated shipments on price, 235-236

Importation on price, 231

Latitude, 15-16

Legislation on price, 231

Long and short growing season, $20-22$

Next crop on price, 232-235

Postal facilities on price, 230

Productivity on price, 238

Soil and climate, 7-24

Speculation on price, 231-232

Sunshine, 15, 20, 23, 45, 46, 47

Tariffs on price, 238

Transportation facilities on price, 230

Variety on "strength," 16

"Visible supply" on price, 235

Elasticity of demand, 207

Elevators, 133, 173-190

Emigration, 299

Emmer, 41, 42

Entre Rios Railway, 164 
Erie Canal, 131, 150-152

"Estancieros," 105, 297

Experimental stations, 104

Exports-

Argentina, 259, 260, 262, 264, 269,270

Canada, 246, 247, 262, 264, 268

Chile, 261

Mexico, 261

United States, 256, 257, 262, 264266

Uruguay, 261

Extension of wheat area, 4, 51, 90, $236,240-244,245,257,259,278$. 295

Extensive farming, 107, 108, 110, 276

Extractive industries, 286, 297

F

\section{Factors of-}

Wheat extension, 284

Yield and quality, 7-40

"Fall" ploughing, 112

"Fall" wheats, 40, 48

Farm-

Animals, 132

Machinery, 110

Size, 105-108

Farmers' co-operative elovators, 192

Farming conditions in America, 103

Fertilization, 11-12, 34-35, 277

Fife wheat, 29, 68, 71, 77

Financial aid, 193, 204, 205

Fixation of types, 28

"Floor trader," 215

Flowing quality of wheat, 132

Fort Simpson, 4, 45, 46, 288

Fort Vermilion, 4, 244, 287

Fort William, 136

"Futures," 210, 211

\section{G}

Gang ploughs, 111, 115

General receipts, 200-210

Geographical distribution, 1-7

Georgian Bay Ship Canal, 147-149

Gluten-content, 15, 22

Government action, 2, 104, 106, 166

Government inspection of wheat, 199,201
Grades, uniformity of, 200-201

Grading, 194, 195, 203

Grain dealers, 192, 193

Grain exchanges, 210

Grain paper, 204-205, 210

Grain privileges, 213-214

Grain ressels, 135, 187, 188

Grain warehouses, 175, 185

Grand Trunk Pacific Railway, 51, 137.138

Great Lakes. 7, 43

Great Lakes route, 139-143

Great Lakes traffic, 135, 156

Great Northern Railway, 138, 152

Great plains of the United States, 60,61

Great Southern Railway, 164

H

"Haciendas," 107

Hagerstown series of soils, 66

Handling, 132

Harrowing, 114-115

Harrows, 115

Harvesters, 115

Harvesting, 115-120

Harvest seasons, 116

Haulage distance, 133

Header binder, 118

Headers, 117

Heat for growth and ripening, 18-20

"Hedging" sales, 212-213

Hudson Bay Railway, 138

Hudson Bay route, 144

Humidity-

Air, 22, 23, 47

Soil, 20

Humus, 10, 14, 36

Hybridization, 26-29

I

Ideal wheat soils, 10

Immigration, 108, 109, 241, 242, $275,285,293,294$

Importance of America in-

Wheat acreage, $2,261-263$

Wheat Exports, 2, 261-263

Wheat Production, 2, 261-263

Importance of transportation, 131

Importance of wheat, 1-2

Independent wheat dealers, 193 
Influence of climate, 14-24

"Inland Empire," 118

Inspection, 194-195, 198

Insurance, 206

Intensive farming, 37, 103, 104, 107, 108, 121, 275-278, 279-280, 292

Intercolonial Railway, 136

Invasion of Canada's wheat-fields, $109,241,242$

Irrigation, 12, 13, 29-31, 279, 290, 291,296

Isotherms-

Argentina, 94

Canada, 55, 56

United States, 78, 80, 90

Italians, 91, 177, 294

K

Kansas City, Mexico, and Orient Railway, 154

Kansas market, 225-226

Killing frost, 71

\section{L}

\section{Labour-}

Cost of human, 110

Quality of, 2, 108, 109

Quantity of, 2, 109, 110

Lake ports, 140, 141

Lake shipments, 140, 142, 156

"Land hunger," 105

Land tenure, 104-106

Law of decreasing returns, 239, 280

Leading wheat soils, 8

L.cading wheat states, 253-254

Legumes, 35-36

Limits of price, 230

Limits of wheat-growing, 5,14

Line elevator companies, 176, 192

Loading methods-

Cars, 175-179

Vessels, 184-185

Load of wheat-

Cars, 134, 170

Carts, 133, 134

Vessels, 135, 152, 170, 188

Loams, 7, 8, 10

Local grain dealers, 193

Locusts, 88-89
M

Maize, 298

Margins, 211

Marketing development : conditions, 206-207

Marketing of wheat, 2, 190-227

Markets-

America, 220-227

Earliest, 209

Local, 132, 209

Primary, 134, 149, 209

Speculative, 209-210

World, 209-210

Marshall series of soils, 64,65

Maturation, 12, 21, 23

Maturity of contracts, 214, 215

"Medianero " systom, 104

"Mediterranean" climate, 62

Mendelian laws, 26-29

Mendelian theory, 26-28

Methods of buying wheat for export, 220

Methods of marketing, 192

Miama series of soils, 64,65

Migration of wheat, 3,4

Minneapolis market, 223-224

Minnesota wheats, 25, 72

Mississippi waterway, 150

Mixing of wheats, 202-203

Moisture effects, $9,12,22$

Noney for moving crops, 204

Montreal Harbour, 140, 146

\section{$\mathrm{N}$}

Nationality, 108, 109

Needs, 59, 69, 70, 72, 74, 76, 78, 82, $96,146,171,272$

New York Central Railway, 154

New York, Lake Erie, and Western Puilway, 154

New York market, 222-223

Nitrates, 10, 14

Nitrogen, 10, 11, 12, 21, 34

Nitrogen content of grain, 11, 12, 13, $20,22,76$

Normal price, 228

Northern Pacific Railway, 152

O

Oceanic climate, 24

Offsets, 216 
Optimum, 12, 13, 14, 22

Oswego series of soils, 66

Ownership of elevators, 181

\section{$\mathbf{P}$}

Pacific coast, $78,156,158,183,185$, 188

Pacifio Highland, 60

Palouse blue stem wheat, 82

Palouse country, 82

Pampas, 86

Panama Canal, 158-160, 289, 290

Payment of differences, 216

Peace River Valley, 4, 289

Pennsylvania Railroad, 154

Periodic variations, 24

Period of growth, 15, 72

Physical characteristics of soils, 8

Physical controls, 1-2

Physiologically dry soils, 9

Ploughing, 38, $111-113$

Ploughs, 111-113

Political controls, 2

PopulationArgentina, 293

Canada, 283, 285

United States, 273, 274

Port Arthur, 136

Ports of call, 220

Possibilities and probabilities-

America, 300-301

Argentina, 293-300

Canada, 284-292

United States, 273-283

Other American countries, 300

Prairies, 10, 43, 61

Prairie soils, 7, 22, 43, 44

Premature ripening, 22

Preston wheat, 28

Previous training, 108, 109

Price, 2, 228-240

Price and wheat acreage, 236-237

Prince Rupert, 131, 146

Principal wheat railways-

Argentina, 167

Canada, 139

United States, 155

Production-

Argentina, 257-259, 262, 264, 269, 270

Canada, 241-246, 262, 264, 268

Chile, 261
Production (continued)-

Mexico, 261

United States, 248-256, 262, 264, 266

Uruguay, 261

Profit on raising wheat, 128

"Puts," 213, 214

R

Railways -

Argentina, 164-167

Canada, 136-139

United States, 152-156

Rainfall effects, 9, 20

Rainfall -

Argentina, 89, 90, 93, 95

Canada, 45, 50, 52, 57, 58

Chile, 100, 101

United States, 62.64, 78.79

Rainfall and temperature curves-

Argentina, 93

Canada, 49, 53

Chile, 101

United States, 75, 81

" Ranchero," 192-193

"Recessive" characteristics, 26, 27

Red Fife wheat, 16, 25, 54

Red River Valley, 65

Red wheat, 40

Reinspection of wheat, 197

Remedies against frosts, 38-39

Rent, 2, 104-106

Retentive capacity of soils, 8-10

"Ringing out" settlement, 217

Roads, 132, 133, 136, 149

Rocky Mountains, 43, 60

\section{S}

Santa Fé Railway, 164

Sault St. Marie ("Soo") Canals, 139

"Scalper," 215

Scientific agrioulture, 1, 37

Season of navigation on the lakes, 140

Seeding, 113-115

Seed selection, 25

Selling by sample, 194, 196

Semi-arid lands, 9, 11, 47, 48, 49

Settlements of contracts (methods), 215-220 
Size of farms, 106-108

Snowfall effects, 54

Soft wheats, 17, 24, 40, 43

Soil moisture, 12, 13, 20

Soils-

Argentina, 86-88

Canada, 43-44, 47, 51, 53

Chile, 98-99

Conditions, 7-14, 23-24, 32

Temperature, 13-14

United States, 7-8, 64-67

Sonora wheat, 78,81

Southerly movement of wheat, 3-5

Southern Pacific Railway, 152-154

Spaniards, 294

Speculation, 209-219

Need of, 209-210

Profits, 213

Spelt, 41-42

Spokane Inland and Electric Railway, 160

"Spot" sales, 219

Spring wheat, 7, 14, 15, 40, 42, 53

Squarehead wheats, 16, 41

Standard of comfort, 2, 207, 208

Stanley wheat, 28

"Steppe" climate, 14, 15, 21, 22, $23,24,49$

St. Lawrence canals, 139-140

St. Lawrence River, 140

St. Louis market, 226-227

Stock raising, 297

Storage, 2, 173-190

Argentina, 169, 176-178, 183186

Canada, 173, 174, 178, 179, 180

Charges, 188-190

Farm, 173-174

Local market, 174-179

Primary market, 179-183

Seaboard, 183-190

Stages, 173

United States, 173-190

Straddles," 213, 214

"Strength" in wheat, 15, 16, 23

Strippers, 118

"Strong" wheats, 16, 22, 23, 24, $25,40,47,72$

Subsoil, 10, 11, 12, 32

Suitability of soils to wheat, 66,67

Summer fallowing, 77

Superior series of soils, 66

Supply, 228-230

\section{$\mathbf{T}$}

Temperature-

Argentine zones, 89

Conditions for growth, 17, 18

Effects, 13, 14, 17, 18

Formation of nitrates, 14

Germination, 14

Maximum, minimum, optimum, 14

Nitrification bacteria, 7, 14

Regions of the United States, 61$62,78-80$

Terminal facilities of a railroad, 183

Thermal constants, 19, 20

Threshing, 119-120

Tillering, 17, 23

Time of cutting, 116-117

Times of harvesting and seeding, 54, $55,68,69,70,72,73,74,78,82$.

$84,90,91,102,114$

"Tosca," 86

Trade profits, 213

Transportation-

Stages, 131-132

To foreign market, 135

To local market, 132-134

To primary market, 134

To seaboard, 134-135

Transportation by countries-

Argentina, 163-171

Canada, 135-149

Chile, 172

United States, 149-163

Uruguay, 172

Transportation chargesArgentina, 170

Canada, 143

United States, 161-163

Transportation and wheat acreage, $282,286,289,290$

Turkey red wheat, $25,33,72,74,78$

Types of rainfall (U.S.), 63-64

\section{$\mathrm{U}$}

Uniformity of prices, 219, 239

Unloading of cars, 181-182

Uruguay, 85, 96, 172, 260, 261, 300

\section{V}

Value of wheat, 228

Vancouver, 131, 290 
Variation in-

Demand, 229-230

Price, 208

Supply, 229

Varieties of wheat-

America, 40-42

Argentina, 91.96

Canada, 42-59

Chile, 100-101

Mexico, 84.85

United States, 67.82

Velvet blue stem wheat, 71

"Visible supply," 235

"Volunteer" wheat, 113

\section{W}

Waterways of Argentine, 167

"Weak" wheats, 15, 16, 17, 40

Weighing, 197-199

Welland Canal, 139

Westerly migration of wheat, 3-4

Western Pacific Railway, 154

Western Railway of Buenos Aires, 164

Wheat breeders, 28, 29

Wheat breeders' problem, 23

Wheat breeding, 26-29, 281-282, 289,296

Wheat farthest North, 4, 5, 287, 288

Wheat " in bond," 141

Wheat on the great lakes, 142

Wheat problems, 272

Wheat receipts at-

Ports, 161

Primary markets, 160
Wheat regions-

Argentina, 91

British Columbia, 43

Canada, 42, 43

Chile, 100

"Dry-farming," 42, 67, 74-77

Durum, 42, 67, 73-74, 91

Hard, "strong," spring, 42, 67, 70.72

Hard winter, 42, 67, 72.73

Irrigated, 42, 67, 77.78

Semi-hard, $67,69.70,91,92,96$

Semi-soft, 91

Soft, $43,67.68$

Soft spring, 43

Southern, 67,70

United State8, 67

White, 67, 78-82

Wheat shipments, 187-188

White wheats, 40,43

Winnipeg, 10, 43, 46, 136

Winnipeg market 227

Winter wheat, $7,16-17,40,42,53,54$

World price conditions, $230-232$

Yield-

America, 126

Argentina, 125

Canada, 122

Chile, 126

Controlling factors, $2,7.40,103$. 127

Mexico, 126

United States, 123-125

Uruguay, 125

THE END 


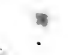






\section{PLEASE do NOT REMOVE \\ CARDS OR SLIPS FROM THIS POCKET \\ UNIVERSITY OF TORONTO LIBRARY}


